UNIVERSIDAD NACIONAL DE LA PLATA

Facultad de Humanidades y Cs. de la Educación

Doctorado en Historia

\title{
Patronazgo rural, dependencia y sociedad de base campesina en la Galia meridional
}

(c. 400-c. 550)

Pablo Sarachu

Tesis para optar por el grado de Doctor en Historia Director: Carlos G. García Mac Gaw

La Plata, 20 de agosto de 2014 


\section{ÍNDICE}

RESÚMENES

INTRODUCCIÓN

\section{CAPÍTULO 1:}

Estado de la cuestión y planteo del problema

1. La idea tradicional de la "decadencia" del imperio romano. 2. Los pioneros de las interpretaciones continuistas. 3. Las interpretaciones continuistas. 4. Balance: ¿una explotación generalizada del campesinado? 5. Una nueva perspectiva. 6. La Galia. 7. Planteo

\section{CAPÍTULO 2:}

Las invasiones germánicas y la caída del Estado imperial en la Galia

1. Prolegómenos. 2. Las invasiones a la Galia. 3. Del asentamiento godo a la pérdida de África. 4. De la pérdida de África a la caída del imperio. 5. El fin del imperio en la Galia

\section{CAPÍTULO 3:}

La Galia romano-germánica hasta c. 550

1. El asentamiento de los visigodos y burgundios. 2. El reino visigodo. 3. El reino burgundio. 4. La expansión franca. 5. La guerra permanente 


\section{CAPÍTULO 4:}

El sistema fiscal

1. El aparato fiscal tardo-romano. 2. El peso del impuesto. 3. Crisis y supervivencia del sistema en la Galia post-romana. 4. Una hipótesis explicativa sobre la crisis fiscal

\section{CAPÍTULO 5:}

Aristócratas y campesinos (i): c. 400-c. 480

1. Cuestiones de definición. 2. Aristocracia y campesinado. 3. Patronazgo y patrocinio. 4. Las bagaudas

\section{CAPÍTULO 6:}

Aristócratas y campesinos (ii): c. 480-c. 550

1. El conflicto de clases. 2. Nuevas formas de ocupación de la tierra. 3. Aristócratas débiles y campesinos independientes. 4. Contracción económica y debilidad aristocrática 


\section{Resumen}

Se argumenta en esta tesis que en la Galia del centro-sudeste se consolidó en torno a mediados del siglo VI una sociedad de base campesina. El estudio aborda la desaparición del estado imperial en la región y la emergencia de los primeros reinos medievales, la crisis del aparato fiscal antiguo y la transformación de las relaciones de dependencia entre aristócratas y campesinos. Se afirma que en el periodo c. 400-c. 550 se produjo la emergencia de núcleos campesinos independientes que terminarían hegemonizando el paisaje rural de la región. Hasta mediados del siglo $\mathrm{V}$, sin embargo, persistieron con fuerza las relaciones de dependencia privada y la extracción de impuestos públicos.

Palabras clave: Galia; Estado tardo-romano; reinos germánicos; campesinado; aristocracia.

\section{Abstract}

It is argued in this thesis that a peasant-base society became established in mid sixthcentury central-east Gaul. The study addresses the disappearance of the imperial state and the emergence of early medieval kingdoms in the region, the crisis of the ancient tax system and the transformation of dependency bonds between the aristocracy and the peasantry. It is stated that the period c. 400-c. 550 saw the emergence of independent farmer nuclei that end up hegemonizing the rural landscape of the region. Until the middle of the fifth century, however, private dependency and taxation persisted with vitality.

Key words: Gaul, late roman State, early medieval kingdoms, peasantry, aristocracy. 


\section{AGRADECIMIENTOS}

Esta tesis es el resultado de un largo y por momentos sinuoso proceso de investigación. Se inició en el año 2006, cuando el Consejo Nacional de Investigaciones Científicas y Técnicas (CONICET) juzgó conveniente otorgarme una beca de financiamiento. El problema que propuse estudiar en mi solicitud, y que me valió luego la admisión en este Doctorado en Historia de la Facultad de Humanidades y Cs. de la Educación, consistía en una profundización de lo que había abordado en la tesina con que me recibí de licenciado, en esta misma casa de estudios. Como sucede en ocasiones, las lecturas y el diálogo con colegas fueron modificando más de lo previsto mis puntos de vista sobre el tema elegido. Las correcciones y reelaboraciones mejoraron, estimo, el producto final, pero el costo fue la dilación del proceso de escritura.

Quisiera agradecer en primer lugar a Carlos García Mac Gaw. En su rol de director estuvo atento a mis inquietudes en todo momento; leyó mis avances con una celeridad poco habitual y tuvo siempre comentarios oportunos, que me ayudaron a comprender mejor el problema que estaba estudiando. Quiero reconocer además su calidez y la generosidad que ha tenido conmigo en otros ámbitos académicos, tanto en la cátedra de Historia General II de esta facultad, como en el Programa de Estudios sobre las Formas de Sociedad y las Configuraciones Estatales de la Antigüedad (PEFSCEA) y en los proyectos de investigación en los que ha sido mi director. Le doy las gracias también porque durante mi segunda estadía en la Université de FrancheComté (UFC) me abrió espacios a los que de otro modo yo no hubiese tenido acceso. 
Carlos Astarita fue mi co-director de las becas doctorales de CONICET y tuvo observaciones agudas sobre los informes que hice para sus seminarios. Sus escritos han sido para mí una constante fuente de inspiración.

He encontrado en estos años dos grandes compañeros con los que imparto los trabajos prácticos de Historia General II. Diego Santos me facilitó buena parte del material bibliográfico con el que trabajé. Las charlas que tuvimos me ayudaron a hacerme una idea más clara de un periodo histórico y una región cuyo interés compartimos. Mariano Spléndido me alentó constantemente y se ofreció a leer los avances. Conversando con él he aprendido mucho de aspectos centrales de la Historia Antigua que son ajenos a mi tema específico.

Quisiera también dar las gracias a distintos colegas con los que comparto otros ámbitos institucionales. A los miembros del Centro de Estudios de Historia Social Europea (CEHSE) de esta facultad y especialmente a mis compañeros del comité de redacción de la revista Sociedades Precapitalistas; a los integrantes del PEFSCEA y a los investigadores del Institut des Sciences et des Techniques de l'Antiquité (ISTA), en la UFC. Entre estos últimos, quiero mencionar en particular a su director Antonio Gonzales, Marguerite Garrido-Hory, Rudy Chaulet y Murielle Faudot, que tuvieron la amabilidad de recibirme y brindarme toda su disposición en mis dos estadías de estudios en el ISTA, en 2010 y 2012. Finalmente, deseo agradecer a Osvaldo Graciano la invitación a formar parte de un proyecto de investigación en la Universidad Nacional de Quilmes, casa de estudios a la que felizmente me incorporé como docente a comienzos de 2013.

Los últimos párrafos están dedicados a mis afectos más cercanos.

Mis suegros, mis cuñadas y mi hermano Víctor fueron un apoyo en todo este tiempo. Mis amigos del secundario y de la facultad no solo contribuyeron directa o indirectamente a mi formación, sino que también estuvieron cerca en los momentos difíciles; quiero mencionar en particular a Leandro Sessa, Luis Santarsiero, Matías Iucci, Horacio González y Andrés Hebrard.

Esta tesis está dedicada a las personas más importantes en mi vida: Antonela, que en unas semanas dará a luz a nuestro hijo Pedro, y mi vieja. Ambas me contuvieron y alentaron durante todo este proceso; solo tengo palabras de agradecimiento.

Quiero recordar finalmente a mi hermano Martín. 


\section{INTRODUCCIÓN}

En esta breve introducción expondremos de forma somera el objetivo y el marco espacio-temporal de esta tesis, por un lado, y describiremos el orden en que será desarrollada, por otro. En cuanto al primer punto, reservaremos al capítulo siguiente el tratamiento con mayor detalle del planteo del trabajo, que se comprenderá mejor una vez realizada la presentación del estado de la cuestión acerca del problema escogido.

\section{OBJETIVO}

El objetivo central de este estudio es demostrar que entre fines del periodo romano y comienzos de la Edad Media se constituyó en la Galia del centro-sudeste una sociedad de base campesina; es decir, una sociedad en la cual las relaciones de dependencia a nivel público y privado eran frágiles y las aristocracias y el poder político se veían obligados a establecer vínculos de relativa reciprocidad con el campesinado. No pretendemos en modo alguno negar la existencia de explotación en la región y en el periodo analizados, sino otorgarle un lugar subordinado frente a las relaciones de producción que no implicaban la transferencia sistemática de excedente de un sector de la sociedad hacia otro. En pocas palabras, se trata de una etapa histórica en la que se consolidó un modo de producción campesino como forma productiva dominante. En cuanto a la geografía escogida, digamos con mayor precisión que ocupa aproximadamente las antiguas provincias de Aquitania I, Lugdunense I, Maxima 
Sequanorum, Narbonense I, Viennense, Alpes Graiae, Narbonense II y Alpes Maritimae.

El marco cronológico del estudio estará circunscrito al periodo que media entre el inicio de la crisis del orden antiguo en la región y el momento en que es probable que el modo de producción campesino se tornase hegemónico. Hemos fijado un tanto arbitrariamente la década de 440 como fecha del primero de los fenómenos mencionados. Es en torno a esos años cuando es posible percibir que el aparato fiscal del imperio de occidente comenzó a tener serias dificultades para funcionar -de las cuales en definitiva no se recuperaría. El cierre del estudio lo hemos fijado de forma un tanto más arbitraria que el comienzo en torno al 550, para cuando probablemente las relaciones de dependencia tradicionales, tanto las privadas entre las aristocracias y los campesinos, como las públicas entre los Estados y sus súbditos, se habían resquebrajado. En adelante los reinos germánicos renunciarían siquiera al intento de imponer el pago de impuestos y los aristócratas tendrían que contentarse con establecer vínculos de reciprocidad con la mayor parte de sus vecinos.

La elección del marco geográfico encuentra dos justificaciones. Si se quiere, una es de orden operativo. Es posible ganar mayor profundidad conforme se va restringiendo el objeto de estudio. En este sentido los desarrollos que percibimos para el centro-sudeste pueden ser extrapolados sin demasiadas modificaciones a toda la región al sur del río Loira, quizás con la salvedad de que en parte de la región aquitana parece haber habido una mayor continuidad en las relaciones de dependencia a juzgar por lo que evidencian las fuentes escritas y arqueológicas. En todo caso habría que dedicar un estudio más específico sobre esta cuestión. La otra razón para el recorte escogido se relaciona con el marco cronológico seleccionado. El análisis del centro-sudeste permite analizar con mayor detalle la crisis del aparato fiscal, que el sudoeste (Aquitania II y Novempopulana ${ }^{1}$ ) no sufrió en tanto fue perdida tempranamente a manos de los visigodos. Digamos finalmente que en la región septentrional de la Galia los procesos de cambio que analizaremos en esta tesis parecen haber comenzado bastante antes, probablemente a mediados del siglo IV; queda en cualquier caso excluida de este estudio.

Esta tesis no trata un tema acotado ni tampoco uno necesariamente novedoso. Con respecto a esto último, si bien es cierto que no se han analizado las relaciones de

\footnotetext{
${ }^{1}$ Aproximadamente la moderna región de Aquitania.
} 
dependencia en un estudio monográfico de la región escogida, el problema ha sido tratado en numerosas ocasiones por la historiografía en trabajos que tomaron un marco geográfico más amplio ${ }^{2}$. Lo que creemos que esta tesis puede aportar es una nueva mirada sobre un viejo problema. Como veremos, esa nueva mirada está en íntima relación con aportes que han venido siendo realizados por otros historiadores.

\section{ORGANIZACIÓN}

Amén de esta introducción, la tesis se inicia con un primer capítulo en el que se presenta un estado de la cuestión acerca de los estudios sobre la historia socioeconómica rural en el periodo tardo-romano y temprano medieval en el occidente latino en general y en la Galia meridional en particular. Es allí, como hemos dicho, donde se amplía el planteo de nuestra investigación.

Los dos capítulos siguientes tratan la historia político-militar del periodo y de la región a estudiar. El propósito del primero de ellos es el de presentar al lector los procesos que finalmente derivaron en el final del orden imperial en occidente y que explican, particularmente, la crisis de su aparato tributario. La coyuntura del conflicto militar abierto entre Roma y los distintos ejércitos invasores desde las postrimerías del siglo IV llevó eventualmente al desmembramiento de la pars occidentis porque el imperio fue incapaz de financiar la defensa de sus territorios. La evolución fue compleja y no se dio sin interrupciones. Por otro lado, otro objetivo al que apuntan estos dos capítulos, pero sobre todo el 3 , es el de dar cuenta de cómo la región se convirtió en escenario de conflictos bélicos recurrentes que en el mediano plazo obstaculizaron la estabilidad de los vínculos de dependencia, no solo porque la vida cotidiana era en sí más insegura (el peligro de saqueo estaba a la orden del día), sino porque la ubicuidad de la guerra en el siglo VI abrió nuevas posibilidades a amplios sectores para incorporarse como soldados en los séquitos de los aristócratas. Un hombre armado normalmente está en mejores condiciones para defender sus derechos, como demuestra, por ejemplo, la historia griega de época arcaica.

\footnotetext{
${ }^{2}$ Aunque tampoco han sido muchos los estudios. Luego de un amplio análisis sobre las formas en que fue estudiada en particular la unidad campesina gala en el pasado, Pierre Ouzuolias llega a la conclusión de que "[la] bilan historiographique esquissé [...] a mis en evidence le faible intérêt des recherches historiques et archéologiques pour la petite exploitation familiale".
} 
El capítulo 4 está dedicado al aparato fiscal. Se analiza allí el proceso de crisis y desaparición del cobro de los impuestos en la región. Las autoridades imperiales debieron aumentar la presión fiscal sobre sus súbditos como consecuencia de la necesidad de atender nuevos frentes de batalla abiertos desde fines del siglo IV. Se sostiene allí que el aparato tributario funcionó más o menos adecuadamente hasta la pérdida de las riquísimas provincias africanas, hecho que supuso un incremento enorme de las exigencias sobre las regiones que aún se hallaban bajo dominio imperial. La corte de occidente ya no fue capaz de financiar los gastos necesarios para la defensa, hecho que aceleró el desmembramiento territorial. Finalmente, como veremos, los nuevos reyes germánicos fueron incapaces de reconstruir con éxito el aparato fiscal, viéndose así imposibilitados de construir relaciones de explotación a nivel público. La forma en la que se financiaron las monarquías de la temprana Edad Media fue a través de la guerra y sus ejércitos no fueron profesionales dependientes de un salario.

Los dos últimos capítulos están dedicados a las relaciones de dependencia privadas, es decir, al vínculo entre aristócratas y campesinos. El primero está circunscrito al periodo $c$. 400-c. 480, es decir, a los años que mediaron entre las invasiones germánicas a la Galia -ocurridas específicamente en 406- y el fin del orden imperial. Tendremos ocasión de analizar allí dos dinámicas divergentes que se solaparon durante parte de esa coyuntura: un proceso de caída en dependencia por parte del campesinado, empujado a la búsqueda de protección frente a la imposibilidad de cumplir con las cargas públicas, y otro de "liberación", de huida y conformación de núcleos independientes, que fue la otra solución a la opresión fiscal. Esa vía de escape fue creciendo con el paso del tiempo y la crisis del orden institucional romano y los espacios de autonomía campesina terminaron hegemonizando el paisaje rural. Este proceso se consolidó en el siglo VI y por lo tanto está tratado con detalle en el capítulo 6, que toma el periodo $c .480-c .550$.

Finalmente, en el apartado dedicado a las conclusiones se hace un hincapié particular en la caracterización de la sociedad de la Galia meridional de mediados del siglo VI como una sociedad de base campesina. 


\section{ESTADO DE LA CUESTIÓN Y PLANTEO DEL PROBLEMA}

El objetivo de este primer capítulo es presentar de manera sucinta el panorama académico actual de la historia socioeconómica rural de la época tardo y post-romana de occidente en general y de la Galia en particular. Con el fin de ofrecer una más clara exposición de los lineamientos centrales de las interpretaciones vigentes, habremos de omitir aquí la referencia bibliográfica pormenorizada y los debates más acotados, que tendrán oportuno tratamiento en el desarrollo posterior de esta tesis doctoral.

En el primer apartado se analizará la idea tradicional de "decadencia" del imperio romano, tomando la obra de A. H. M. Jones como ejemplo de la misma e hilo conductor para la exposición de sus características centrales. Posteriormente abordaremos las tesis que enfatizan la continuidad entre el mundo antiguo y el medieval. Dentro de esta línea, daremos cuenta de los trabajos pioneros de Dopsch y Pirenne y abordaremos los de historiadores más recientes (Peter Brown, Walter Goffart y los llamados "fiscalistas", principalmente). Propondremos entonces un balance sobre el problema de la explotación del campesinado en base a las teorías presentadas. Luego nos referiremos a la innovación que han supuesto los recientes trabajos de Chris Wickham en torno al periodo comprendido entre los años 400 y 800 y a cómo permiten repensar el problema abordado en esta tesis. En el sexto apartado se presenta el tratamiento que ha recibido la región de la Galia dentro del panorama presentado y 
finalmente en el último, y teniendo en cuenta lo expuesto, detallamos con mayor precisión los objetivos de esta investigación.

\section{LA IDEA TRADICIONAL DE LA "DECADENCIA" DEL IMPERIO ROMANO}

La idea de que la época tardo-romana (c. siglos III-V en occidente) fue la versión decrépita de los años dorados de la república y el principado gozó durante mucho tiempo de un amplio consenso, aunque no hubiese unanimidad en qué se entendía por esa "decadencia" 3 . En este apartado expondremos los planteos centrales que desde estas perspectivas se propusieron para la historia socioeconómica, sin pasar por alto que estaremos tratando con interpretaciones que de ninguna manera conforman una escuela monolítica. Nos valdremos de dos trabajos representativos de una mirada "decadentista", pero a la vez provenientes de corrientes historiográficas diferentes: The later roman empire, de A. H. M. Jones y The Class Struggle in the Ancient Greek World, de Geoffrey de Ste. Croix, que aún siguen siendo una referencia significativa para los especialistas. Por último, la presentación no estará exenta de referencias al estado actual de las investigaciones sobre determinados aspectos de estas tesis, particularmente aquellos que se encuentran más abandonados.

La obra de Jones constituye tal vez el último trabajo de síntesis de una historia socioeconómica y sociopolítica del imperio romano posterior al ascenso de Diocleciano que se encuadra dentro la tesis de la decadencia ${ }^{4}$. Su publicación es casi contemporánea de los inicios de la renovación historiográfica que instaló en el ámbito académico el concepto de "Antigüedad tardía”. En el último capítulo de su libro, Jones sistematiza los distintos problemas que había debido enfrentar el imperio romano in toto a partir de fines del siglo III, delimitando, no obstante, las diferencias fundamentales de los derroteros de oriente y occidente. La explicación de que la pars orientis no hubiese caído radicaba en su opinión en el hecho de haber estado mejor preparada para afrontar los trastornos: por un lado, era más rica y estaba más densamente poblada que occidente

\footnotetext{
${ }^{3}$ Un repaso de las diferentes posturas historiográficas sobre la crisis del siglo III y el fin del mundo antiguo en Fernández Ubiña 1982.

4 Además, continúa siendo bibliografía ineludible para cualquier estudio sobre la organización administrativa del Estado tardo-imperial.
} 
y, por otro, la riqueza estaba distribuida menos desigualmente, lo que se traducía en la existencia de una aristocracia senatorial menos poderosa que la de occidente y en un campesinado que retenía una mayor cuota de la producción ${ }^{5}$. En este sentido, puesto que su tesis pone énfasis en la debilidad interna del imperio, los factores que contribuyeron a la decadencia lograron un desarrollo pleno en occidente.

Esto no significa pasar por alto el claro componente externo que tiene la explicación del declive en Jones, aspecto de su obra que en general ha sido desdeñado por los especialistas ${ }^{6}$. Según su criterio, oriente no solo era estratégicamente menos vulnerable que occidente, sino que además estaba menos sometido a la presión de los bárbaros que su contraparte. Por otro lado, el aumento de los gastos estatales, detonante de todos los problemas económicos en su opinión, había sido motivado en gran medida por la necesidad de robustecer la maquinaria bélica, cuestión que en última instancia se conectaba con el elemento externo ${ }^{7}$.

De cualquier forma, el énfasis argumentativo se hallaba en los factores internos. La tesis central consiste en que durante el imperio tardío las exigencias en materia fiscal - principalmente- y en el aumento del peso de las rentas privadas crecieron en forma desproporcionada a las capacidades productivas. Particularmente en la esfera estatal se había expandido desmesuradamente el número de "bocas ociosas" (idle mouths) existentes. Por un lado, la burocracia, y sobre todo el ejército, aumentaron enormemente su tamaño desde fines del siglo III, requiriendo un presupuesto elevado que se financió con un fuerte incremento de los impuestos ${ }^{8}$. Por otro lado, se multiplicó el número de eclesiásticos con la progresiva cristianización del imperio9 ${ }^{9}$. La presión fiscal terminó siendo intolerable para los contribuyentes al producirse un desequilibrio relativo entre la masa de productores y un engrosado sector improductivo dentro del cual seguía cumpliendo su rol tradicional la aristocracia terrateniente ${ }^{10}$.

\footnotetext{
${ }^{5}$ Jones 1964, 1064-1068.

${ }^{6}$ E. g. Heather 2006, 559-560. La desestimación se justifica en parte en que el propio Jones no profundiza la explicación "externa".

${ }^{7}$ Jones 1964, 1027, 1030-1031 y 1039.

${ }^{8}$ Véase Garnsey y Saller 1991, cap. 2, para la reducida burocracia del principado.

${ }^{9}$ Los monjes y eremitas también eran para Jones "bocas ociosas" (1964, 1046-1047), en tanto dependían, en su mayoría, de las limosnas de los campesinos. Solo algunos, aquellos que vivían de su trabajo, quedaban excluidos. Por otra parte, los monasterios habían ido adquiriendo tierras que no eran labradas por los propios monjes sino por mano de obra dependiente.

${ }^{10}$ Jones 1964, 1054-1057. Cabe agregar que en su opinión el proceso de centralización administrativa provocado con Diocleciano además de aumentar el número de funcionarios hizo que el sistema se volviera menos eficiente.
} 
El argumento de las "bocas ociosas" encontró eco en la historiografía marxista. En la obra de G. E. M. de Ste. Croix se inserta como un aspecto coadyuvante de la crisis. Según este autor, a partir del principado se habría ido dando en el imperio una progresiva sobreexplotación de los sectores dependientes, cuya consecuencia fue una igualmente gradual decadencia del sistema. En ese contexto, la expansión de la burocracia desde las reformas de Diocleciano en adelante constituyó un agravante de la situación de las masas explotadas al traducirse en un incremento de la presión fiscal ${ }^{11}$.

Como quedará claro más adelante, en realidad la burocracia civil no tuvo una gran incidencia en el presupuesto global del Estado. Si bien es cierto que durante los siglos III y IV se expandió mucho más que el aparato militar (cuyo crecimiento quizás rondara el 50\%), fue el ejército el que continuó representando la principal fuente de erogaciones para los gobiernos imperiales ${ }^{12}$.

A partir de esta matriz argumentativa, Jones encadena en un entramado de consecuencias que devienen causas una serie de procesos que en su despliegue contribuyeron a la caída del imperio. En primer lugar, destaca la "ruina" de la agricultura. En su opinión, la imposibilidad de hacer frente a las exigencias fiscales por parte de los contribuyentes condujo a un progresivo abandono de las tierras marginales, económicamente inviables ${ }^{13}$. Ciertamente, hoy resultaría muy arriesgado sostener que hubo una crisis generalizada de la agricultura en el siglo IV para la mayor parte de occidente (por no hablar de oriente, que no nos incumbe en este trabajo) ${ }^{14}$. En cualquier caso, el pretendido repliegue habría tenido a su vez consecuencias demográficas: la población se contrajo ante la imposibilidad de continuar explotando tierras "marginales".

La cuestión merece párrafo aparte. La demografía es un campo de estudios particularmente espinoso para el historiador de la Antigüedad, carente de documentación apropiada para su estudio. De hecho, depende casi enteramente de la arqueología, disciplina que, para ser justos, aún estaba en deuda con la materia en la época en que Jones escribió su obra ${ }^{15}$. En consecuencia, los datos aportados por este

\footnotetext{
${ }^{11}$ de Ste. Croix 1988, 584-586.

12 Véase el capítulo 4.

13 Jones (1964, 1039-1040) se apoya en las sucesivas leyes sobre agri deserti para respaldar esta conclusión. Cabe aclarar que en su opinión los abandonos pudieron obedecer también al agotamiento por sobreproducción, a la escasez de fuerza de trabajo y, en las fronteras, a la amenaza de los bárbaros.

${ }^{14}$ Véase el capítulo 4.

${ }^{15}$ Scheidel 2007.
} 
historiador son pobres $\mathrm{y}$ obedecen principalmente a acontecimientos puntuales $\mathrm{o}$ referencias en la legislación ${ }^{16}$. La explicación se opera en el campo de la lógica más que en el de la demostración empírica: en una economía que no importaba productos y con una gran parte de la población en el nivel de subsistencia, el abandono de tierras tuvo que haber provocado para Jones una subproducción alimenticia, impidiendo el sostenimiento de tasas de natalidad capaces de contrarrestar las de mortalidad ${ }^{17}$. Por lo tanto, el crecimiento de los sectores improductivos habría cooperado con esta dinámica de contracción poblacional, al forzar un aumento desproporcionado de los impuestos y las rentas -necesarios para sostenerlos- en relación a la productividad de la tierra disponible. Ciertamente, la cuestión demográfica excede los propósitos de nuestro trabajo, aunque se abordará tangencialmente en la medida en que sea pertinente. Es preciso señalar en todo caso que los datos disponibles gracias a las prospecciones arqueológicas de los últimos tiempos permiten sostener la tesis de una drástica caída demográfica en occidente durante el periodo de larga duración comprendido entre $c$. 400 y c. $800^{18}$.

Cabe citar también el rol central que algunos investigadores atribuyeron al comercio para explicar la decadencia del imperio romano, caracterizando el siglo III como una época de transformación que determinó el paso de una economía "liberal" de mercado a una dirigista (como veremos Henri Pirenne también atribuyó al comercio un rol esencial para explicar el fin del mundo antiguo, aunque en un periodo muy posterior $)^{19}$. Jones defendió la hipótesis de la existencia de una contracción en el mercado de productos corrientes hacia el bajo imperio debido al empobrecimiento del campesinado, del proletariado urbano y de los estratos inferiores de los curiales, es decir, como consecuencia y no como causa de la recesión económica general ${ }^{20}$. En cualquier caso, sus elaboraciones se acercan a las de la llamada tesis "primitivista", que

\footnotetext{
${ }^{16}$ Menciona por ejemplo como datos relevantes a nivel imperial una gran plaga aparecida bajo el reino de Marco Aurelio que tuvo réplicas durante el siglo III o determinados raids de bárbaros que provocaron matanzas que iban seguidas de hambrunas y epidemias. Por otro lado, para demostrar el descenso de los niveles de reproducción natural se apoya en las leyes contra el infanticidio y en datos sobre ventas de niños. Si las primeras pueden demostrar la voluntad del Estado de que hubiese un mayor crecimiento vegetativo (aunque no sea una conclusión necesaria), no se ve cómo los segundos puedan aducirse para hablar de descenso demográfico.

${ }^{17}$ Jones $(1964,1042-1045)$ reconoce que el crecimiento demográfico en sociedades premodernas obedece al sostenimiento de tasas de natalidad extraordinariamente altas, capaces de sobreponerse no solo a índices de mortalidad elevados, sino también a las catástrofes demográficas propias de las economías precapitalistas.

${ }^{18}$ Ward-Perkins 2000a.

${ }^{19}$ Rostovzeff [1926], cap. 12.

${ }^{20}$ Jones 1964, 1039-1040.
} 
proponía minimizar la importancia del mercado en la economía antigua. El puntal de esta corriente fue M. I. Finley, quien no cuestionó la retracción comercial durante dicho periodo, sino que la redujo a un cambio ocurrido en el marco de una economía eminentemente agrícola y destinada principalmente al autoconsumo ${ }^{21}$. En cualquier caso, la idea de una contracción del mercado desde el siglo III resulta difícil de defender; la restauración económica del siglo IV incluye en este sentido una clara recuperación del comercio mediterráneo (evidenciada palmariamente por la arqueología) $)^{22}$.

Otro factor que para Jones colaboró en la caída del imperio fue la corrupción en la esfera de la administración civil, particularmente en los estamentos más bajos del funcionariado. Algunas de las pruebas que sostienen su argumento son endebles, pues las fuentes que revelan sobornos o cohechos esconden por lo general intereses en pugna entre facciones de poder ${ }^{23}$. No obstante, debe reconocerse que su hipótesis se fundamenta también en datos más sólidos, como el hecho de que durante el bajo imperio se difundiera la práctica de establecer comisiones (sportulae) semilegales y se generalizase la compra de los cargos, hecho este último que para Jones alentaba la venalidad porque instaba a los funcionarios a recuperar su inversión ${ }^{24}$. De todos modos parece que continuó primando la lógica clientelística en la nominación para los cargos burocráticos $^{25}$. En cualquier caso, esta es otra cuestión que en toda su complejidad excede el interés de esta tesis. El problema de la corrupción estatal será abordado en el capítulo 4 de forma circunscrita, vinculado específicamente a la cuestión de la presión fiscal en la Galia de mediados del siglo V en adelante.

Un engranaje primordial dentro del funcionamiento del aparato estatal $-\mathrm{y}$ del sistema fiscal- lo constituían los curiales. No es extraño entonces que su rol durante el periodo tardo-romano ocupe un lugar destacado en las interpretaciones "decadentistas". Llamativamente, Jones excluye su tratamiento del capítulo final de su obra, donde ordena hechos y procesos en función de la explicación del hundimiento imperial. Les dedica en cambio parte del capítulo sobre la evolución de las ciudades y su gobierno

\footnotetext{
${ }^{21}$ Finley [1973]; 1982.

${ }^{22}$ Carrié y Rousselle 1999, 513-561; Giardina 2007, 763-764. Leveau $(2007,669)$ habla de "ausencia de crecimiento" para el periodo tardo-imperial (cuestión que podría discutirse para la segunda mitad del siglo V).

${ }^{23}$ Kelly 1998, 175-180.

${ }^{24}$ También se pagaba por evitar la carga pública que significaba ser designado curial (Jones 1964, 10551080).

${ }^{25}$ Kelly 1998, 172-173.
} 
durante el bajo imperio y sus planteos son recogidos y ampliados por de Ste. Croix ${ }^{26}$. Entre otros deberes, los curiales no solo eran los responsables de la recaudación de los impuestos frente a las instancias superiores del Estado, sino que además debían responder con su propio patrimonio las deudas pendientes de su jurisdicción ${ }^{27}$. Para de Ste. Croix, entre fines del siglo II y el siglo VI se produjo en el imperio romano una progresiva decadencia de los curiales. El deterioro se relacionaba directamente con el aumento del peso fiscal, que según su criterio había comenzado a sentirse fuertemente a partir del reinado de Marco Aurelio, momento en el que la amenaza de los bárbaros obligó a un incremento de los gastos militares. Hacia los siglos IV y V, fue emergiendo además una escisión interna (una "lucha de clases" en su opinión) dentro de la aristocracia urbana de la cual se nutría la curia municipal, en virtud de la cual los miembros más ricos lograron integrarse al funcionariado imperial, escapando a las cargas de la civitas, o bien consiguieron imponerse en cada consejo por sobre los miembros más pobres. De esta forma, impuestos cada vez más elevados fueron exigidos a curiales provenientes de sectores cada vez más empobrecidos de las elites locales. El resultado frecuente fue la pérdida de la propiedad o la huida ante la incapacidad de responder a las exigencias ${ }^{28}$.

De igual forma que la cuestión de la corrupción, el análisis de la situación de los curiales adquiere importancia dentro del estudio de la fiscalidad tardo-romana y como tal será retomado más adelante. Sin embargo, cabe mencionar aquí que la tesis de la decadencia de los curiales ha recibido objeciones. Se ha insistido en este sentido en las oportunidades de enriquecimiento que se abrían dentro de la administración municipal, hecho que explicaría la puesta en venta de los cargos. Asimismo, se han reinterpretado las leyes que obligaban a estos funcionarios a permanecer en sus puestos como una herramienta para evitar sobre todo la huida ascendente (al ejército o la Iglesia) ${ }^{29}$. Por último, la incapacidad de las autoridades imperiales para frenar los abusos de los curiales sobre sus administrados estaría demostrada por la repetida legislación en su contra $^{30}$. De todos modos, es probable que las defecciones estuvieran relacionadas en ocasiones con la imposibilidad de hacer frente a las obligaciones fiscales. El derrotero

\footnotetext{
${ }^{26}$ Jones 1964, cap. 19. Véase también Rostovzeff [1926], 467-475.

${ }^{27} \mathrm{La}$ mayor parte de las leyes concernientes a los derechos y obligaciones de los curiales del periodo que va de Constantino a Teodosio II están reunidas en C. Th., 12.1.1-192.

${ }^{28}$ de Ste. Croix 1988, 542-552.

${ }^{29}$ E. g. Cameron 1998, 104-105 y 179-182.

${ }^{30}$ Lepelley 1983, 150-154.
} 
de los curiales en sus funciones dependía de un juego político complejo que involucraba a las instancias superiores del gobierno imperial, a otros miembros de la curia (superiores o inferiores) y a los contribuyentes (que incluía un espectro que iba de los potentes a los campesinos). Pese a que cabe afirmar que el gobierno municipal fue en general una fuente de enriquecimiento para las aristocracias a lo largo de siglo IV y parte del siguiente, lo cierto es que en un contexto de fuerte exigencia fiscal por parte del gobierno imperial (como ocurrió en la Galia hacia mediados del siglo V) las contradicciones inherentes al "juego" descrito podían resolverse en detrimento de los curiales.

Como hemos señalado anteriormente, el argumento de la sobreexplotación del campesinado fue puesto en el centro de la escena por de Ste. Croix. Varias páginas de su The Class Struggle in the Ancient Greek World están dedicadas a explicar cómo el lento proceso de degradación de los derechos de las clases inferiores se tradujo en una incapacidad de resistencia frente a los embates de las clases dominantes. La ruina de los curiales sería parte del fenómeno, junto con la erosión de los derechos de los libres pobres, que se habría consolidado ya para $c \cdot 150-c \cdot 200^{31}$. En consecuencia, desde fines del siglo II se habrían ido "apretando las tuercas" no solo de los terratenientes hacia sus dependientes y del Estado a los contribuyentes -principalmente los campesinos propietarios-, sino también de ambos hacia la clase curial, que es la que, según de Ste. Croix, cargaba sobre sus espaldas el peso de las obligaciones evadidas por la clase senatorial $^{32}$. El aumento de las "bocas ociosas" a partir de fines del siglo III habría sido un factor que profundizó un proceso que ya estaba en marcha al traducirse en pesadas obligaciones fiscales. La sobreexplotación explicaría, finalmente, la ausencia de resistencia popular frente a las invasiones bárbaras y los casos de huida y cooperación. Esta fue la expresión que en su opinión tomó la "lucha de clases"; no la de las rebeliones abiertas ${ }^{33}$.

Vale rescatar, para concluir esta presentación, el intento de este último historiador por buscar una explicación a las transformaciones del mundo tardo-romano en la dinámica de las relaciones sociales de producción, un tema muy relegado en la historiografía actual. Regresaremos oportunamente sobre sus argumentos, algunos de los cuales resultan muy sugestivos para pensar las relaciones entre campesinos,

\footnotetext{
${ }^{31}$ de Ste. Croix 1988, 528-539.

32 de Ste. Croix 1988, 542-552.

${ }^{33}$ de Ste. Croix 1988, 552-586.
} 
aristocracia y Estado en la Galia de los siglos V y VI. Simplemente interesa indicar aquí que de Ste. Croix minimiza el hecho de que la mayor parte de la población civil del imperio romano careciera de entrenamiento militar y de armas para enfrentar a un ejército (en parte por haber vivido, fronteras adentro, una paz casi ininterrumpida desde el inicio del milenio, hecho que contrasta con la realidad del periodo post-romano ${ }^{34}$ ). Podría aducirse que las bagaudas tuvieron no poco éxito con pertrechos básicos, pero este fenómeno tuvo un desenvolvimiento muy focalizado ${ }^{35}$. La desmilitarización contribuyó, en nuestra opinión, a que los carriles de la resistencia discurriesen por los cauces de la fuga individual, proceso que debe volver a jerarquizarse en el análisis de la caída del orden antiguo.

\section{LOS PIONEROS DE LAS INTERPRETACIONES CONTINUISTAS}

Alfons Dopsch escribió entre los años 1918 y 1920 los Fundamentos económicos y sociales de la cultura europea, una obra innovadora que ha sido injustamente relegada en la actualidad como referencia en los estudios del periodo ${ }^{36}$. El autor atacaba en ella a dos corrientes historiográficas en boga en su tiempo: la que proponía la inexistencia de diferenciación social entre los germanos antes del siglo IX (la "teoría de la marca") y la que postulaba que las invasiones bárbaras habían arrasado con el mundo romano, imponiendo una solución de continuidad categórica con el pasado. Esta última no debe confundirse sin embargo con las posturas de historiadores como Jones y de Ste. Croix. La crítica de Dopsch apuntaba, en sus palabras, contra la "teoría del cataclismo" que se había originado con el humanismo del siglo XV y que se había prolongado en grandes portavoces de la ilustración e historiadores decimonónicos. En breve, se pretendía que Europa había vivido en la más absoluta barbarie desde la caída del imperio romano hasta el inicio de la época moderna, una idea que todavía encuentra eco en frases populares de tinte negativo como "volver a la Edad Media"37.

\footnotetext{
34 Compárese con la situación de guerra casi permanente de los primeros tiempos de los reinos germánicos.

${ }^{35}$ Véase el tratamiento de la cuestión en el capítulo 5.

${ }^{36}$ Como advierte Wickham 2005, 1.

${ }^{37}$ Dopsch [1918-1920], 19-23 y 75-92.
} 
A pesar de esto, Dopsch no se despegó totalmente de la tesis de la decadencia. En su opinión, el ingreso progresivo de los germanos al imperio desde la época cesariana en adelante solo habría servido como paliativo de la crisis social y económica originada a partir de un problema interno, la escasez de mano de obra servil (la colonización habría comenzado a revertir el declive económico recién a partir del siglo VI $)^{38}$. Propuso además un muy lento cambio evolutivo -no exento de contrapuntoshacia una simbiosis romano-germánica cuyo comienzo se remontaba al periodo cesariano y encontraba su mejor expresión en el ámbito social rural. En su opinión, la escasez de mano de obra y el descenso demográfico se habrían ido revirtiendo conforme se produjeron las migraciones germánicas, mientras en la estructura social se producían cambios apenas perceptibles, pero claros, en el tránsito de la Antigüedad a la Edad Media $^{39}$. De cualquier forma, como hemos señalado, la investigación arqueológica actual permite constatar que durante los años c. 400-c. 800 hubo un descenso demográfico general en Europa, no una expansión, por lo que el argumento de Dopsch sobre este punto debe ser descartado de plano.

El austríaco señaló también que hacia el bajo imperio el poder de los terratenientes se habría ido sustrayendo cada vez más del ámbito público al privado, emergiendo así auténticos señoríos explotados por un campesinado dependiente ${ }^{40}$. Su tesis encontró resonancia posterior en historiadores que asociaron íntimamente el fenómeno de "alienación" de la esfera estatal por parte de los potentes con la aparición del patrocinium como mecanismo de evasión fiscal mediante el cual los contribuyentes de menores recursos se ponían bajo protección de los señores ${ }^{41}$. De todos modos, la feudalización de Europa -entendida como el proceso de establecimiento de grandes dominios privados sustraídos al poder público- distó mucho de estar completada para Dopsch en dicho periodo. La evolución fue compleja y no careció de interrupciones. Para el caso del área franca, el reinado de Clodoveo habría presentado un freno a la expansión de los señoríos, tras el cual hubo un recrudecimiento como consecuencia de las guerras entre los reyes sucesores, que en busca de apoyo militar a sus pretensiones se vieron obligados a favorecer a los sectores aristocráticos privados a través de donaciones de tierras; un interrupción muy breve se habría dado nuevamente durante la

\footnotetext{
${ }^{38}$ Dopsch [1918-1920], 80, 190.

${ }^{39}$ Dopsch [1918-1920], 85-87 y 152-153.

${ }^{40}$ Dopsch [1918-1920], 156-157 y 185.

${ }^{41}$ Un ejemplo claro en Alföldy 1987, 284-290.
} 
reunificación política bajo Clotario $\mathrm{I}^{42}$. Otro obstáculo en el desarrollo del feudalismo estuvo dado, para el autor, por la promulgación de leyes que tendían a proteger a los campesinos frente a los poderes privados absorbentes, una medida que se comprendería dentro del contexto global de lucha entre monarcas y señores. En relación a esta cuestión, Dopsch señala asimismo la existencia durante la primera época de los reinos germánicos de asentamientos de colonos libres impulsados por los monarcas, especialmente sobre tierras fiscales que a menudo eran producto de expropiaciones señoriales; incluso destaca la protección que hacía el conde de los derechos de los campesinos en algunas regiones ${ }^{43}$.

Esto último resulta revelador de una situación general que fue muy diferente a la de una hegemonía de la gran propiedad, tesis por otra parte sostenida por el propio Dopsch. Habrá que preguntarse en todo caso en qué medida cabe hablar de una política deliberada de protección de sectores campesinos libres por parte de los reyes y no del reconocimiento de la imposibilidad de avanzar sobre su independencia. En nuestra opinión, este historiador percibe algunos de los atributos sociológicos esenciales del periodo, pero sin darle la debida relevancia. En particular, destaca la mejora en la condición de buena parte de los sectores inferiores como consecuencia de la fuga de coloni y servi de sus señores, proceso cuyo cenit sitúa en el periodo carolingio pero que en nuestra opinión se encuentra plenamente desplegado desde el siglo VI. Por otro lado, ensaya a menudo explicaciones poco satisfactorias, como cuando propone que dicha mejoría se debió en gran medida a la acción que la Iglesia desplegaba en favor de la protección de las clases pobres y oprimidas ${ }^{44}$.

Henri Pirenne propuso un continuismo más radical. En su Mahoma y Carlomagno, formuló la tesis de que la historia antigua se había prolongado sin cortapisas en el mundo mediterráneo hasta la consolidación de las conquistas árabes en oriente y el ascenso de los carolingios en el reino franco. El libro sentó las bases para una profunda reinterpretación del periodo que iba aproximadamente del siglo III al VIII, el que pasaría a ser etiquetado en el mundo académico como la "Antigüedad tardía"; gran éxito para un borrador preliminar que nunca llegó a ser revisado y que fue editado post-mortem con mínimas modificaciones en el año 1935.

\footnotetext{
${ }^{42}$ Dopsch [1918-1920], 256-258, 270, 388-389 y 408.

${ }^{43}$ Dopsch [1918-1920], 186-189 y 283-284.

${ }^{44}$ Dopsch [1918-1920], 299-302 y 333-340.
} 
La civilización antigua tuvo para Pirenne un carácter eminentemente mediterráneo, rasgo que no solo no entró en decadencia en la era post-diocleciana, sino que por el contrario se reafirmó. La crisis del siglo III había sido claramente superada para la centuria siguiente, que abrió una era de plenitud comercial que no se interrumpió hasta el advenimiento de los árabes en el antiguo territorio del imperio romano de oriente. Por otra parte, el establecimiento de los reinos germánicos en occidente no habría representado para el historiador belga una solución de continuidad de orden económico, social o incluso político. La única idea tradicional que siguió haciendo suya fue la de que a partir del bajo imperio se había producido una decadencia moral, cultural e intelectual en todo el orbe antiguo ${ }^{45}$.

La continuidad de las estructuras estatales en los reinos germánicos suponía una propuesta profundamente innovadora, incluso en relación a las elaboraciones de Dopsch. Para el historiador belga, los invasores mantuvieron intacta la estructura estatal heredada, reemplazando el vértice político con una corte real, que era ahora la expresión a escala reducida del poder despótico imperial. La razón se fundamentaba en la voluntad de los bárbaros de participar de una romanitas que admiraban profundamente y que no anhelaban destruir por razones raciales, religiosas o políticas. La continuidad se dio asimismo en el ámbito local, en donde las aristocracias romanas se mantuvieron como miembros del episcopado urbano y negociaron cuotas de poder con las comitivas de los reyes ${ }^{46}$. Como veremos más adelante, estos planteos encontraron un posterior desarrollo en los trabajos de Walter Goffart y en términos generales gozan hoy de amplia aceptación.

Por otra parte, el sistema fiscal se habría conservado intacto en los reinos germánicos, aunque con un carácter menos gravoso, suponiendo así un alivio para los campesinos. Esto estaba vinculado, para Pirenne, a la disminución de los gastos estatales por la simplificación de la administración y la presencia de un ejército asentado en la tierra ${ }^{47}$. De cualquier forma, el aparato tributario se habría mantenido lo suficientemente en pie como para constituirse en fuente de una fabulosa riqueza para los monarcas. Esta hipótesis también fue profundizada por historiadores posteriores, nuevamente en particular por Goffart, quien propuso que la conservación del aparato fiscal estaba íntimamente vinculada a los tratados de asentamiento celebrados entre el

\footnotetext{
${ }^{45}$ Pirenne [1935], 97-114.

${ }^{46}$ Pirenne [1935], 39-52.

${ }^{47}$ Pirenne [1935], 43-46.
} 
imperio y los distintos pueblos germánicos ${ }^{48}$. Volveremos sobre esta cuestión más adelante.

Pirenne propuso que la continuidad socioeconómica se basaba en "las personas y las tierras". Si bien en ocasiones las grandes propiedades pasaron a manos de los bárbaros (un caso concreto fue el del norte de África), en general los dueños de la tierra habrían seguido siendo los mismos, esto es, la aristocracia romana y la Iglesia. Esta idea de fuerte estabilidad contrasta con las políticas de enajenaciones y donaciones monárquicas que Dopsch destaca, a pesar de todo, en su libro. Para Pirenne la continuidad se dio asimismo en los dominios rurales, que siguieron estando a cargo de esclavos y de coloni adscriptos a la tierra. Por lo tanto, no solo habría subsistido la forma de explotar el suelo, sino que además, la gran propiedad habría seguido estando "llena de vigor". De hecho, en su opinión no hubo decadencia económica en todo el periodo $^{49}$.

En suma, según el historiador belga hubo pervivencia de la estructura socioeconómica: persistencia de la aristocracia terrateniente -laica y eclesiástica- y de los sectores dependientes. El pequeño campesino propietario, que apenas recibe tratamiento en su obra, parece carecer de relevancia. En última instancia, la continuidad del sistema se explicaba, en su opinión, en la existencia ininterrumpida hasta aproximadamente el 700 de una red de intercambios de escala mediterránea.

Pirenne partía en su argumentación del presupuesto de una continuidad del flujo comercial que ha sido refutada por los estudios arqueológicos, los cuales han demostrado un complejo y variado proceso de retraimiento y regionalización del antiguo mercado de alcance mediterráneo en dicho periodo. Retomamos en este punto el minucioso análisis reciente de Chris Wickham, quien ha atribuido el fenómeno no solo al colapso del sistema fiscal imperial sino también al empobrecimiento de las $\operatorname{aristocracias}^{50}$.

\section{LAS INTERPRETACIONES CONTINUISTAS}

\footnotetext{
${ }^{48}$ Goffart 1980, 40-54.

${ }^{49}$ Pirenne [1935], 62-96.

${ }^{50}$ Wickham 2005, 693-824; 2012. Véase el tratamiento más amplio de la cuestión del comercio en el capítulo 6.
} 
A partir de los años '70 del siglo pasado se ha ido instalando con fuerza en el ámbito académico una concepción global novedosa de los periodos tardo-romano y temprano medieval. Esta corriente abrevó de los postulados continuistas mencionados anteriormente -en particular de la tesis de Pirenne- para reconsiderar los años transcurridos entre c. 200 y c. 700 bajo un nuevo rótulo, el de la "Antigüedad tardía”. El periodo era considerado ahora como una época en sí misma y no como una mera transición entre la Antigüedad clásica y la Edad Media. El éxito en la innovación se dio especialmente en el terreno de la historia cultural y religiosa, pues sus portavoces lograron desterrar de este tipo de estudios la idea de "decadencia" que durante tanto tiempo había sido indiscutible (y que, como hemos visto, hasta el propio Pirenne retomaba).

El impacto académico fue tan fuerte que implicó un reemplazo del glosario básico de los especialistas. Términos semánticamente fuertes como "decadencia", "crisis" o "hundimiento" han dado paso a otros de cariz neutral, como "cambio" y "transformación", o decididamente positivos, como "revolución" y "refreshment" fue ajeno a este proceso el impacto general que en la historiografía han venido teniendo desde hace varias décadas tanto la inquietud por los estudios culturales y religiosos, como, particularmente, las corrientes interpretativas que fijan la atención en los discursos (a veces confundiéndolos con la realidad fáctica). Esto ha sido reconocido incluso por algunos de los adalides de este revisionismo. Glenn Bowersock, por ejemplo, ha llegado a plantear que la caída de Roma "ya no es necesaria", convirtiendo así lo empírico en una dimensión cuya relevancia depende exclusivamente de la voluntad del sujeto cognoscente (en este caso el historiador ${ }^{52}$. Otros, paradójicamente, han adoptado los postulados de esta corriente desde una convicción positivista, pues les permitiría despojarse de los "juicios valorativos" de los historiadores del pasado para acceder a un conocimiento más objetivo de la realidad ${ }^{53}$.

El éxito que ha tenido en el mundo académico esta profunda renovación ha hecho que algunos de sus defensores relegaran su deuda con los pioneros del continuismo en el afán de enfatizar los errores de los axiomas que venían a

\footnotetext{
${ }^{51}$ Ward-Perkins 2005, 4.

52 Bowersock 1996, 38-42. Afortunadamente, todavía hay autores que consideran la caída de Roma como un hecho trascendental.

${ }^{53}$ E. g. Cameron 1998, 19.
} 
desmantelar ${ }^{54}$. Así, en pos de exagerar la crítica a los “decadentistas", se ha llegado a plantear que la explicación del hundimiento del imperio como producto de una crisis económica obedecía a un mito inventado conscientemente ${ }^{55}$ o que el común denominador de quienes interpretaban la historia tardo-romana bajo el signo del "colapso" era la proyección al pasado de aspectos "decadentes" del presente ${ }^{56}$. Sin embargo, aún reconociendo la aceptación que ha despertado en una enorme porción de los historiadores especializados en el área, debe señalarse que no han faltado trabajos especialmente dedicados a criticar aspectos medulares de la nueva corriente ${ }^{57}$.

La existencia de antecedentes lejanos no quita mérito alguno a la figura de Peter Brown, una suerte de gurú de esta profunda renovación historiográfica. Su The world of late Antiquity nos servirá de hilo conductor para la presentación de los lineamientos centrales de la misma, si bien debemos adelantar que en ciertos aspectos fue menos innovador de lo que se ha pretendido. En ese pequeño gran libro, editado originalmente en el año 1971, Brown propuso percibir globalmente el periodo c. 200-c. 700 como un progresivo abandono de la herencia clásica, planteando la existencia de una lenta transformación de carácter social y religiosa ${ }^{58}$. De esta forma, se oponía a los defensores de la tradicional idea de "caída y decadencia" del imperio romano, aunque ciertamente no negaba la debilidad económica occidental de la última etapa del Estado imperial ni el impacto político de su desaparición ${ }^{59}$.

Brown destacó en cambio la "restauración" que había vivido el mundo imperial en el siglo IV. En su opinión, la sociedad romana del periodo había sido sorprendentemente rica, flexible y equilibrada, aunque estructuralmente diferente de la del periodo clásico. En este sentido, su análisis presentaba, paradójicamente, ciertas coincidencias con las elaboraciones de A. H. M. Jones. Para Brown, en la sociedad

\footnotetext{
${ }^{54}$ Incluso en aquellos aspectos en los que la nueva corriente ponía ahora el énfasis -la religión, la culturacabe encontrar antecedentes historiográficos lejanos. Ya en el siglo XIX había sido esbozada una reinterpretación del periodo tardo-romano en términos de "renovación" y "refreshment" cuyo acento estaba puesto en dichas cuestiones. Véase al respecto Bowersock 1996, 33-34.

${ }^{55}$ Cameron 1998, 94.

${ }^{56}$ Carrié y Rousselle 1999, 11-14. Aunque ciertamente el argumento es válido para ciertos casos, entre los que se destaca el de Rostovzeff.

${ }^{57}$ E. g. C. Wickham, B. Ward-Perkins, J. H. W. G. Liebeschuetz y P. Heather, por mencionar solo historiadores de renombre. No es de extrañar que los citados provengan del ámbito académico británico, quizás uno de los más reticentes a abandonar la conceptualización del periodo 400-800 como "temprana Edad Media" (early Middle Ages).

${ }^{58}$ Brown profundizó estas ideas en 1978.

${ }^{59}$ De hecho en el apartado final sobre bibliografía (su trabajo no tiene notas) Brown recomienda como un análisis "agudo y pertinente" de la debilidad económica y política del Estado romano The awful revolution de Walbank, cuyo subtítulo era The Decline of the Roman Empire in the West.
} 
tardo-romana, particularmente en la occidental, la brecha entre ricos y pobres fue muy amplia y la tributación mucho mayor, inflexible y peor distribuida que antes. El autor continuaba implícitamente otorgándole relevancia a la caída de Roma. La explicación apuntaba a que el imperio en occidente había terminado derrumbándose por una desafección casi inconsciente de las aristocracias senatoriales y la Iglesia católica con respecto al aparato estatal cívico-militar. El fin de la "restauración" se habría producido tras la conquista de las aristocracias gala e italiana de la esfera pública civil a partir del gobierno de Teodosio; de allí en adelante, el Estado habría empezado a ser utilizado exclusivamente en función de los intereses particulares de estas clases. Lamentablemente, Brown no se explaya sobre cuáles eran esos intereses particulares, pero todo indicaría que las aristocracias habían apuntado a profundizar el poder en la esfera privada sirviéndose del Estado más que sirviéndolo. En este punto, no se alejaba mucho de la tesis que sostenía que durante el periodo tardo-romano se había ido produciendo una progresiva alienación de los aristócratas con respecto al poder público, una idea que como vimos se hallaba presente en Dopsch. La otra gran razón que en su opinión explicaba la caída del imperio era la incapacidad de occidente para lidiar con el problema bárbaro $^{60}$.

Brown reinstalaba además uno de los planteos centrales de Pirenne al proponer que las bases de poder de las aristocracias occidentales se habían mantenido intactas gracias al contacto con las nuevas cortes bárbaras y la dominación de las sedes episcopales ${ }^{61}$. La novedad estribaba en todo caso en que la continuidad de la estructura sociopolítica se daba para Brown en un mundo que de ninguna manera debía catalogarse de decadente; un mundo que, en todo caso, atravesaba un cambio cultural y religioso que lo llevaría a abandonar lentamente la tradición clásica ${ }^{62}$.

Desde el punto de vista de la historia sociopolítica una interpretación más radical vendría con los estudios de Walter Goffart. Como hemos señalado anteriormente, la decadencia del imperio romano fue explicada durante muchos años como un proceso generado o catalizado por las invasiones germánicas (entendidas muchas veces en un sentido amplio, que englobaba los asentamientos formales de laeti y las incursiones que se habían iniciado en el siglo III). Que nos ocupemos aquí de esta cuestión obedece al

\footnotetext{
${ }^{60}$ Brown [1971], 43-57 y 139-151.

${ }^{61}$ Brown [1971], 152-156.

${ }^{62}$ Brown [1971], 207-208.
} 
nexo directo que en nuestra opinión tuvieron los acontecimientos político-militares de la última centuria del imperio y las trasformaciones socioeconómicas. Dedicaremos el capítulo siguiente a explayarnos sobre esta cuestión, haciendo epicentro en la Galia; ahora nos ocuparemos del argumento tradicional sobre las invasiones y de la tesis de Goffart.

La interpretación tradicional sobre la caída del imperio se remonta al humanismo bajomedieval y fue sostenida en sus aspectos esenciales por la generalidad de los especialistas hasta el siglo XIX inclusive. Hemos indicado ya que Dopsch dedicó parte de su obra a atacar estas posturas, vigentes cuando escribía; también lo hizo Pirenne ${ }^{63}$. Ciertamente, los embates del ámbito académico desde comienzos del siglo XX han desterrado algunas de esas ideas, que a menudo no estaban exentas de connotaciones racistas o nacionalistas.

Quienes primero se opusieron a las teorías tradicionales no habían rechazado la entidad misma de las invasiones y las conquistas; más bien habían señalado que la voluntad de los germanos era la de mantener en la medida de lo posible las estructuras de un imperio que admiraban. El éxito en la tarea fue interpretado de manera distinta. Para Dopsch los Estados romano-germánicos que surgieron en el siglo V coronaron un proceso que se había iniciado mucho antes de César, consistente en asentamientos campesinos pacíficos y migraciones individuales que habían engrosado el ejército y la burocracia de los romanos ${ }^{64}$. Los bárbaros habían hecho entonces una primera conquista silenciosa, integrándose como subordinados. Pero el final del proceso no había sido otro que la toma del poder por vía militar, que el historiador austríaco no minimizó en ningún momento a pesar de que el contexto historiográfico en el que escribía lo incitase a poner el énfasis en las cuestiones que habían sido soslayadas por sus contemporáneos. En este sentido, solo a posteriori de los enfrentamientos bélicos, el "acuerdo" entre vencedores y vencidos habría impedido que la época de las invasiones se constituyese en una "gran solución de continuidad" 65 .

Pirenne había hecho mayor hincapié en el aspecto conservador de los reinos germánicos, como hemos visto, pero tampoco desestimó el impacto social inmediato de las conquistas. Su postura de todos modos difiere en aspectos importantes de la de Dopsch y anticipa desarrollos historiográficos posteriores. En síntesis, interpretó la

\footnotetext{
${ }^{63}$ Pirenne [1935], 20-52.

${ }^{64}$ Dopsch [1918-1920], 79.

${ }^{65}$ Dopsch [1918-1920], 88-92.
} 
caída del gobierno imperial como un episodio violento dentro de una continuidad evolutiva. La Romania había sobrevivido, pues el propósito de los pueblos invasores había sido establecerse y “disfrutar" del mundo romano, no destruirlo ${ }^{66}$.

Estas consideraciones subyacen en Barbarians and Romans (1980) y trabajos posteriores de Goffart, historiador que inició una profunda revisión historiográfica al sostener que las invasiones germánicas habían consistido en gran medida en asentamientos pacíficos mediante tratados de ayuda militar. En su opinión, lo que había sido interpretado unánimemente como la caída de Roma, fue en realidad un “experimento que se fue de las manos" ${ }^{67}$ luego de la cesión voluntaria por parte del gobierno imperial de los derechos de cobro de impuestos sobre algunas partes de su territorio a cambio del servicio militar de los beneficiarios. Goffart no era, por cierto, indiferente al hecho de que efectivamente algunos pueblos bárbaros se habían instalado en territorio romano a través del expediente liso y llano de la conquista militar. Sin embargo, estimaba que esto había sido una excepción a la regla general que había consistido en la sanción oficial imperial ${ }^{68}$.

$\mathrm{Su}$ argumento soslaya el hecho de que detrás de los acuerdos se escondían relaciones de fuerza desigual entre las partes. El yerro es propio de un formalismo extremo que no indaga en las relaciones concretas de unos contrayentes equiparados ficticiamente en los contratos. Únicamente así puede sostenerse que África haya sido entregada de buena gana por el gobierno imperial a cambio de una alianza militar con los vándalos. El abocamiento primordial de todos los emperadores posteriores a la década de 440 a la reconquista de ese auténtico granero de occidente evidencia el carácter no voluntario del acuerdo.

Se reinterpretaba así la historia política del siglo $\mathrm{V}$ como un retiro casi voluntario de los emperadores de occidente del gobierno de las provincias ${ }^{69}$. En opinión de Goffart, puesto que la debilidad de esa parte del imperio consistía en la conflictividad recurrente en torno a la púrpura, la decisión de confiar la defensa territorial a bárbaros que estaban excluidos de la lucha por el trono había sido definitivamente atinada. Por otro lado, el imperio no había presentado decididamente batalla a los bárbaros porque

\footnotetext{
${ }^{66}$ Pirenne [1935], 20-29.

${ }^{67}$ Goffart 1980, 35.

${ }^{68}$ Goffart [1981], 12-13.

${ }^{69}$ Goffart [1981], 24-30 deja entrever incluso que la idea de que occidente "cayó" frente a los bárbaros fue una invención oriental que comenzó a fines del siglo $\mathrm{V}$ y que preparó el terreno para la reconquista de Justiniano.
} 
habría preferido no gastar recursos en ellos ${ }^{70}$. Más que un análisis político-militar, los emperadores habían hecho entonces un cálculo de costo-beneficio puramente económico. En cualquier caso, la continuidad en las regiones ocupadas habría de ser asegurada por la población romana, que sobreviviría con el vigor suficiente como para tener un efecto decisivo sobre los gobernantes godos, francos, lombardos y anglosajones. Las aristocracias en particular, retendrían posiciones de gran dignidad y eminencia $^{71}$.

Goffart daba así nuevos bríos a la tesis continuista. Sus tesis han sido acogidas por muchos y llevadas aún más lejos por otros ${ }^{72}$. Se ha llegado a plantear para el caso galo que la instalación de los bárbaros fue un cambio que se desarrolló de forma "natural, orgánica y generalmente pacífica"73. Conmovido por el éxito académico de este revisionismo, Bryan Ward-Perkins dedicó recientemente un libro al propósito de reinstalar las invasiones germánicas como un acontecimiento histórico de primerísimo orden, violento, indeseado y con unos efectos directos sobre la caída del imperio romano $^{74}$. En el siguiente capítulo retomaremos algunos de sus planteos centrales.

Quienes llevaron al paroxismo la tesis continuista fueron los fiscalistas, que conectaron esta renovación historiográfica con otra, la de la tesis mutacionista, que sugería que el feudalismo se había originado a partir de una revolución hacia el año 1000 .

Jean Durliat, una de las cabezas visibles de esta corriente, publicó en el año 1990 un controvertido trabajo que sintetizaba algunas líneas interpretativas que compartía junto con otros historiadores como Elizabeth Magnou-Nortier y Karl Ferdinand Werner. Allí proponía reinterpretar todo el periodo que iba del gobierno de Diocleciano a la caída del imperio carolingio como un continuum tanto político-administrativo como socioeconómico. Los reinos germánicos y el imperio carolingio habrían conservado, según su criterio, las características esenciales del imperio romano: eran Estados burocráticos extractores de impuestos que "funcionaron" de manera plena.

Hasta aquí, se comprenderá que esto no comportaba más que una cierta radicalización de argumentos continuistas preexistentes. Sin embargo, la inmutabilidad

\footnotetext{
${ }^{70}$ Goffart [1981], 15-21.

${ }^{71}$ Goffart [1989], 130-132.

${ }^{72}$ Véanse las referencias bibliográficas en Ward-Perkins 2005, 10, nn. 19 y 20.

${ }^{73}$ Shanzer y Mathisen 2001, 1.

${ }^{74}$ Ward-Perkins 2005.
} 
de las estructuras socioeconómicas era entendida de manera distinta a la tradición heredada. En efecto, Durliat revalorizó el lugar del pequeño campesino propietario, quizás influenciado por el acento que los defensores de la tesis mutacionista habían hecho de la abundante evidencia de alodios en la Europa anterior al año 1000. Esto lo llevó a plantear una muy arriesgada redefinición de lo que se entendía por colonato y por gran propiedad. En su opinión -y en la de los fiscalistas-, la forma dominante de explotación de la fuerza de trabajo durante todo el periodo habría sido la tributaria, siendo las villae y los fundi que aparecen en las fuentes simples unidades fiscales. La tierra tenía así un status doble: era a la vez propiedad eminente del Estado (administrada por sus representantes, los possessores) y propiedad útil de los súbditos tributarios (los coloni e incluso los servi, eran vistos como propietarios plenos de la tierra y no como tenentes). Consecuentemente la aristocracia dejaba de ser la gran propietaria privada de tierras para pasar a constituirse como un grupo de personas privadas en cuyas manos se delegaba autoridad pública (es decir, burócratas) ${ }^{75}$.

Toda esta reinterpretación de la estructura social tardo-romana y temprano medieval ha perdido vigor en la actualidad y ha recibido duros reveses por parte de otros historiadores. Ha sido particularmente demoledora la pormenorizada reseña que Chris Wickham dedicó al libro de Jean Durliat. Incorporamos aquí sus planteos al tiempo que los hacemos extensivos como crítica general de esta corriente. Para el historiador británico, el problema central de toda la tesis del francés resulta en última instancia de una mala lectura de las fuentes producto de que razona como un historiador del derecho. Por ejemplo, Durliat propone que los possessores eran agentes recaudadores en base al significado atribuido a términos relacionados a "possessio" en algunas disposiciones del Codex Theodosianus. Como bien plantea Wickham, el problema no estriba en que en un determinado texto administrativo se utilice la palabra "possessio" en un sentido fiscal, como unidad de tributación, sino que de allí se deduzca que todas las possessiones eran propiedades eminentes. Durliat procede de igual manera con las expresiones "villa", "fundus", "colonus", etc., otorgándoles el valor semántico que anteriormente referimos, siempre con base en una reinterpretación de fuentes jurídicas o administrativas. Adelantemos aquí que la documentación específica de la Galia del siglo V da por tierra con su argumento. La referencia de Salviano de Marsella

\footnotetext{
75 Durliat 1990. Una buena síntesis de las posturas centrales de esta escuela están puede verse en Salrach 1993, esp. 99-102.
} 
a campesinos que para evadir los impuestos huían de sus tierras para convertirse en coloni de señores privados no puede comprenderse si no se establece una distinción entre campesino propietario y colonus arrendatario ${ }^{76}$. Wickham se toma el trabajo de enumerar otros muchos ejemplos en los que dichos términos adquieren el significado que habitualmente le ha dado la historiografía. Finalmente, hace una muy fuerte impugnación de la pretensión de Durliat de que existió una continuidad ininterrumpida con funcionamiento pleno del aparato administrativo y fiscal en los reinos germánicos y el imperio carolingio, que en conjunto con las críticas anteriores fundamentan su desmantelamiento de la tesis del historiador francés ${ }^{77}$.

\section{BALANCE: ¿UNA EXPLOTACIÓN GENERALIZADA DEL CAMPESINADO?}

Actualmente existe cierto acuerdo sobre lo que se consideran las características centrales de la estructura socioeconómica rural de las épocas tardo y post-romana. Sigue los lineamientos historiográficos anteriormente expuestos, excepción hecha de los postulados centrales de la tesis fiscalista y de los aspectos menos vigentes de las tesis “decadentistas" a los que se hizo somera referencia. En palabras de Chris Wickham, los estudios de la alta Edad Media -comprendida en su opinión entre los años 400 y 800siguen orientándose según el viejo paradigma establecido por Dopsch y, sobre todo, Pirenne ${ }^{78}$.

Con matices según las corrientes y los historiadores, se considera en general que la aristocracia tardo-romana fue más rica que la alto imperial. En una evolución lenta y desplegada a través de distintas vías, sus miembros fueron acumulando fortunas a través de ilícitos que cometían en tanto funcionarios públicos y de donaciones de tierras y oro que les proporcionaba el emperador a cambio de apoyo político. A esto se sumaba la transmisión patrimonial por herencia. Por otro lado, tanto los campesinos propietarios como los miembros menores de las aristocracias locales, fueron las víctimas de este orden de cosas, a cuya costa se habría producido dicha acumulación de riquezas por las elites más encumbradas. No habría sido ajeno a todo este proceso el sistema fiscal: aún

\footnotetext{
${ }^{76}$ Salv., De gub. Dei, 5.8.43-9.45.

${ }^{77}$ Wickham 2003.

${ }^{78}$ Wickham 2005, 1-5.
} 
cuando su naturaleza siga siendo materia de discusión, pocos rechazan que se había convertido en una presión en ocasiones insostenible que forzaba a los contribuyentes de menores recursos a desprenderse de sus propiedades o a buscar formas ilegales de protección. Finalmente, las invasiones germánicas no habrían supuesto una solución de continuidad a la realidad descrita, pues amén de que algunos historiadores sigan destacando la violencia que caracterizó la conquista, la idea dominante es que los reinos post-romanos experimentaron una recomposición y una restauración de la vida social.

En cuanto a las clases inferiores, debe destacarse el abandono casi completo en el ámbito académico de la vieja tesis de la decadencia de la esclavitud. Actualmente casi ningún historiador subestima la persistencia de la mano servil en la Europa latina durante el periodo estudiado ${ }^{79}$. Incluso parece haber escasa controversia con respecto al lugar de los esclavos en el proceso productivo, pues suele haber acuerdo en que el grueso de los servi tardo-romanos y temprano medievales fueron casati, esto es, trabajadores dependientes a quienes se les asignaba una parcela de tierra para su manutención a cambio de una renta ${ }^{80}$. De todos modos, tiende a soslayarse el hecho de que a partir del siglo VI -y aún antes- las abundantes referencias a esclavos rebeldes y fugitivos permiten ver las serias dificultades que tenían los amos para hacer efectiva su dominación.

En suma, el campesinado del occidente latino de los siglos V al VI (para ajustarnos al periodo de nuestro interés) es visto en general como una clase sometida a una dura explotación, ya sea a través del impuesto o por medio de la renta. Como hemos señalado, hay opiniones encontradas con respecto al grado de incremento de los gravámenes fiscales. En particular ha quedado desacreditada la hipótesis de Jones de que el sistema fue duro e inflexible a partir de la misma reforma de Diocleciano. Pero pocos niegan que efectivamente los impuestos hayan aumentado, lo que supone que el campesino propietario debió de hacer frente a una carga constante sobre su producción

\footnotetext{
${ }^{79}$ Para la vieja tesis de la decadencia de la esclavitud, véanse $e$. g. Staerman [1952] y Finley 1982, 160194. Antes que ellos, Dopsch ([1918-1920] 309-312) y Bloch ([1947]) ya habían dado cuenta de la ingente cantidad de esclavos que hubo en el periodo temprano medieval. El estudio de este último, un artículo sin notas pero plagado de referencias fácticas, sirvió de inspiración a Bonnassie (1991) para proponer que el sistema esclavista no había entrado en crisis sino hasta el siglo X.

${ }^{80}$ Consenso que sin embargo parte de una interpretación inadecuada del esclavismo romano. La cuestión de la explotación de esclavos en el marco de lo que comúnmente se denomina la "villa clásica" parece haber sido una realidad bastante más acotada geográfica y cronológicamente de lo que ha menudo se ha pensado, por lo que en realidad debería ponerse en duda la existencia previa de un "modo de producción esclavista" entendido según el modelo del sistema productivo de la plantación esclavista americana. Véase al respecto García Mac Gaw 2006 y en prensa.
} 
de cuanto menos un quinto de la cosecha, si no más ${ }^{81}$. Por otro lado, coinciden en estas consideraciones globales los fiscalistas, que niegan la existencia de renta privada del suelo y consideran a todo el campesinado como un sector sometido a explotación en el marco de un sistema tributario.

En cuanto a las relaciones de explotación en el ámbito privado, el análisis es a todas luces más difícil de generalizar. De cualquier modo, suele considerarse que el vínculo entre los terratenientes y sus dependientes (libres o esclavos) tendió a agravarse o, en el mejor de los casos, continuó de manera más o menos estable. Para muchos el endurecimiento del sistema fiscal habría contribuido indirectamente a profundizar las relaciones de explotación privadas, ya fuera a través de la legislación que limitó una serie de derechos de los coloni o del incentivo a la formación de redes ilegales de evasión que sometían al campesinado a la dependencia señorial ${ }^{82}$. En cualquier caso, el contexto de una maquinaria tributaria de sólido funcionamiento y de una aristocracia opulenta que concentraba la propiedad de la tierra presupone la existencia de mecanismos estables de extracción del excedente.

Finalmente, buena parte de estos postulados parte implícita o explícitamente del supuesto de que el campesinado tardo-romano fue, en palabras de Jones, “apático y dócil" ${ }^{\prime 83}$. En cierta forma, la ausencia de movimientos abiertamente rebeldes (excepción hecha de las bagaudas) da cierto sustento a esta conclusión. El propio de Ste. Croix, que intenta revalorizar otra forma de expresión de la resistencia campesina en la huida hacia los bárbaros o la aceptación pasiva de la conquista, termina llegando a conclusiones similares ${ }^{84}$. Sin embargo, ha tendido a subestimarse la acción individualizada como expresión de lucha social. La abundante información que los documentos nos transmiten respecto de fugas y rebeldía de esclavos (e incluso coloni) pone en evidencia la creciente incapacidad que encontró tanto la aristocracia en el ámbito privado como el Estado en el público para explotar al campesinado. Esta idea forma el núcleo duro de

\footnotetext{
${ }^{81}$ Ese es el cálculo de Durliat (1990, 16-19), que Wickham $(2003,83)$ considera conservador.

${ }^{82}$ Véase el tratamiento de la cuestión en el capítulo 5.

${ }^{83}$ Jones 1964, 1061.

${ }^{84}$ Para de Ste. Croix (1988, 528-539) el deterioro de los derechos de los libres de sectores bajos en el imperio, ocurrido entre el siglo II y principios del siglo III, probablemente no fue una política deliberadamente buscada por los terratenientes para tener un mayor dominio (extraer más renta) sobre sus dependientes, pero efectivamente esto último fue un corolario de lo primero. El resultado fue entonces la pérdida de poder de resistencia frente a la explotación, el origen de una clase servil que reemplazó la explotación tradicional del esclavo en el marco de la villa. Una explicación que, contra lo que él mismo pretende, se asemeja bastante a la propuesta por Finley (1982).
} 
esta tesis doctoral. En nuestra opinión, los orígenes de este proceso pueden rastrearse para la Galia del centro-sur hacia mediados del siglo V.

\section{LA NUEVA PERSPECTIVA}

Chris Wickham ha reinterpretado de forma novedosa el periodo comprendido entre los años 400 y 800 en un excepcional estudio comparativo sobre diez grandes regiones europeas y mediterráneas ${ }^{85}$. La reciente obra constituye la culminación de una trayectoria profesional de tres décadas, jalonada por distintos trabajos de investigación que anticiparon varias de sus ideas centrales.

Con respecto a las regiones que habían formado parte del imperio romano, Wickham analiza sus derroteros individuales como evoluciones con ritmos diferenciados dentro de una tendencia general iniciada por una contracción, como producto de la crisis del Estado antiguo, y seguida de un desarrollo, gracias a la "reemergencia" de relaciones feudales de producción ${ }^{86}$. Para el caso galo, el ámbito geográfico de nuestro interés, Wickham data el declive de la región al norte del Loira en torno a los años 350-500 (con un desarrollo aparentemente sostenido a partir de $c$. $550)^{87}$, mientras que en el sur la crisis recién se daría durante el siglo VI (para prolongarse al menos hasta el siglo VIII) ${ }^{88}$.

Por otra parte, en buena parte de las regiones que estudia, la contracción permitió en su opinión el avance de sociedades de base campesina o del modo de producción campesino. Entiende por sociedad de base campesina aquella en la que impera una lógica de producción centrada en el hogar de la familia nuclear campesina en un contexto aldeano. La finalidad de cada una de las unidades es producir lo estrictamente necesario para la reproducción de la casa y el mantenimiento de las relaciones con el exterior. Estas últimas tienden a ser recíprocas, imperando los vínculos de don y contra-don, tanto en sentido horizontal (entre las células campesinas) como

\footnotetext{
${ }^{85}$ Wickham 2005.

86 Aunque hace prevalecer las líneas convergentes de desarrollo de las distintas regiones en su caracterización global de la Europa del 400-800 (Wickham 2005, 827-831).

${ }^{87}$ Según lo planteado en 2001 y en 2005, 794-805. De cualquier forma, en 2005, 576, Wickham propone una preponderancia del modo de producción feudal en toda Francia a partir de los siglos VII-VIII.

${ }^{88}$ En 2001, 565-566, Wickham había planteado que el sur recién conoció un desarrollo importante hacia el siglo XI, postura que revisa en 2005. De cualquier modo, ambas fechas caen mucho después del cierre de nuestro análisis.
} 
vertical (con el poder político y/o las aristocracias). La predominancia de este modo de producción no solo supone la inexistencia de lazos de dominación estables en el interior y hacia el exterior de la aldea, sino que incluso los dificulta ${ }^{89}$.

Las regiones con predominancia del modo campesino habrían interactuado con núcleos "feudales" de producción, es decir, con áreas en las que primaba la extracción de renta por parte de las aristocracias. La relación entre los modos de producción feudal y campesino tuvo variaciones espacio-temporales que Wickham ilustra a través de la imagen de la piel de un leopardo: sobre un "fondo" representado por un mundo campesino de dominación inestable, "manchas" de distinta intensidad y distribución representarían la presencia de relaciones de explotación feudales.

Para ser rigurosos, el historiador británico tiende a utilizar indistintamente los conceptos "modo de producción” y "sociedad de base campesina", cuando el segundo debería hacer referencia específica a la formación económico-social en la cual el primero es predominante. La rectificación no es antojadiza, en la medida en que estamos estudiando una sociedad caracterizada por tener más de un modo de producción. El propio Wickham da cuenta de esto en todo momento al emplear la analogía de la "piel de leopardo" para explicar la distribución geográfica de núcleos feudales y campesinos. Además, es taxativo al afirmar que el modo feudal impera en occidente solo a partir de $c$. $700-800^{90}$. Por nuestra parte, entonces, utilizaremos el concepto de "sociedad de base campesina" en referencia a la formación económicosocial en la cual el modo campesino es predominante ${ }^{91}$.

Esto se vincula íntimamente con el problema fiscal. Para Wickham el sistema impositivo entró en crisis en occidente luego de la caída del imperio y durante el siglo VI. Por eso el modo "feudal" en el periodo tardo-romano consistió principalmente en la extracción de rentas y no de impuestos ${ }^{92}$. Los Estados romano-germánicos tuvieron

\footnotetext{
89 Wickham 2005, 536-550. El concepto de "modo de producción campesino" fue desarrollado por Sahlins (1983) en el campo de la antropología. Los fundamentos ya estaban presentes en Chayanov [1925].

${ }^{90}$ Wickham 2005, 570-588.

${ }^{91}$ Se amplía esta caracterización en las Consideraciones finales.

${ }^{92}$ Wickham (2005, 60; cf. 1989 y [1985]) ha dejado de considerar el feudal como un modo de producción en sí mismo para pasar a entenderlo como un subtipo del modo de producción tributario, el cual abarcaría toda relación de extracción de plusvalía en el contexto de una sociedad agraria. Esta reelaboración parte de Samir Amin ([1973]), siendo luego retomada por Haldon (1993), entre otros, y ha sido criticada por Astarita (1994). Por ello es que Wickham habla de "reemergencia" del modo feudal de producción. Por nuestra parte, coincidimos con García Mac Gaw (2003a) en que la diferencia en la forma en que se extrae el excedente incide en la caracterización de los modos de producción precapitalista. Véanse las Consideraciones finales a esta tesis.
} 
muchas dificultades para conservar el aparato fiscal y cuando lo lograron los impuestos fueron comparativamente menores a los romanos. Esto tuvo consecuencias importantes en la medida en que, como plantea el autor, el Estado tributario fue el agente más efectivo de extracción del plusproducto de la gran parte de la población en el imperio $\operatorname{tardío}^{93}$.

Wickham formula así una réplica contundente a las tendencias hegemónicas actuales en la historiografía, abriendo perspectivas superadoras que ya han sido retomadas por otros. Jean Pierre Devroey, por ejemplo, se ha inspirado en trabajos anteriores del británico sobre las sociedades campesinas temprano medievales para presentar batalla a las interpretaciones continuistas (incluida la de los fiscalistas) en el campo de los estudios sobre el mundo franco de los siglos VI-IX ${ }^{94}$.

Por nuestra parte, nos inspiramos fuertemente en esta nueva perspectiva para intentar ofrecer una reinterpretación de las características centrales de la estructura social rural del centro-sur de la Galia de los siglos V y VI. El concepto de "sociedad de base campesina" permite revalorizar las rupturas por sobre las permanencias y volver a situar en un plano central el papel de la resistencia de los campesinos como factor fundamental para explicar las relaciones sociales de la época. En este punto retomamos las observaciones hechas por Carlos Astarita a la tesis de Wickham, orientadas a enfatizar la dominación del modo de producción campesino a toda la Europa occidental entre el 400 y el 800. En particular, haremos propia su invitación a pensar su expansión en la Galia como el producto de una "lucha social multiforme" en un contexto de debilitamiento político ${ }^{95}$. Por otro lado, y paradójicamente, la hipótesis que nos proponemos explorar supone tomar una dirección contraria al análisis que el propio Wickham hace de la región, singular, en su criterio, por haber tenido una aristocracia "inmensamente rica" 96 .

\section{LA GALIA}

\footnotetext{
${ }^{93}$ Wickham 2005, 82. Por otro lado, los impuestos no desaparecieron para ser reapropiados como renta señorial como propone Goffart [1972]; [1982a] y [1982b]. Ver sobre esto Wickham 2005, 533-534.

94 Devroey 2003 y 2006.

95 Astarita 2007, 259. Cabe añadir que si, según su criterio, ésta es la explicación que debe buscarse a la implementación del modo campesino en la Galia, España e Italia, para los casos inglés y danés -tratados por Wickham en su obra- las causas deberían buscarse en otro lugar (el repentino retiro del gobierno imperial y una evolución interna propia, respectivamente).

${ }^{96}$ Wickham 2005, 169-203.
} 
Muchos de los historiadores referidos hasta aquí dedicaron partes específicas de sus trabajos al estudio de la situación gala e incluso generalizaron a partir de este caso. Sin embargo, carecemos de un estudio actualizado de síntesis sobre la estructura social rural consagrado especialmente a la Galia de este periodo de transición entre la Antigüedad y la Edad Media. Ello ha sido advertido por Wickham en Framing, libro que de alguna forma ha contribuido a llenar ese vacío en el marco de un estudio comparativo regional mayor ${ }^{97}$. Sí contamos con trabajos temática y geográficamente más acotados. Los estudios micro-regionales han mostrado un avance fuerte en las últimas décadas, particularmente de la mano de la arqueología, que ha venido demostrando un creciente interés por las estructuras rurales del periodo y cuyos frutos parciales pueden verse reflejados por ejemplo en las actas del IV Coloquio de la asociación $\mathrm{AGER}^{98}$. Pero la historiografía ha tendido a abandonar temas tradicionales de historia socioeconómica como la esclavitud, el patronazgo rural o el colonato que no pueden resolverse únicamente a través del registro arqueológico ${ }^{99}$.

En cualquier caso, el estado de la cuestión sobre la historia socioeconómica rural de la Galia tardo y post-romana reproduce a grandes rasgos los lineamientos historiográficos definidos anteriormente. La tesis tradicional de la decadencia podemos encontrarla por ejemplo en el somero estudio de Marcel Le Glay sobre la historia rural de la región en la época romana, donde se caracterizan los siglos III y IV como un periodo de crisis y mutaciones debidas a las invasiones germánicas y la burocratización y militarización del aparato estatal. Para este autor, la Galia había experimentado un gran desarrollo económico desde la conquista romana -llegando a su apogeo durante el siglo II- con base en la orientación hacia el mercado de los grandes dominios (aunque la tendencia al autoconsumo no fuera totalmente abandonada en ningún momento) ${ }^{100}$. Sin embargo, durante el bajo imperio el ámbito rural habría padecido la devastación de muchas regiones a manos de los invasores germanos y de los cada vez más numerosos bandidos. La respuesta fue el abandono de zonas vulnerables en favor de otras más seguras (como los oppida prerromanos) y la fortificación de ciertas propiedades que ahora hacían las veces de "castillos". Le Glay recrea un mundo rural en

\footnotetext{
${ }^{97}$ Wickham 2005, 42.

${ }^{98}$ Ouzoulias y otros 2001.

${ }^{99}$ Véanse $e$. g. Samson 1992; Drinkwater 1989 y 1992 y Grey 2006 para el tratamiento de estos temas en el área específica de la Galia.

${ }^{100}$ Le Glay $1975,206-207$ y $233-273$.
} 
descomposición, en el cual se va consolidando una aristocracia extremadamente rica que concentra en pocas manos la propiedad de la tierra y que ya no ejerce el poder desde el tradicional ámbito urbano ${ }^{101}$.

Esta imagen de la época tardo-romana ha quedado relativamente marginada en el ámbito académico. Los siglos IV y V reciben actualmente una valoración más positiva, caracterizándoselos como un periodo de reestructuración económica y de crisis acotadas ${ }^{102}$. Incluso se interpretan las transformaciones urbanas de aquellos tiempos como signos de una vitalidad vinculada a la continuidad en el funcionamiento de la economía antigua y al lugar destacado como residentes de los sectores aristocráticos ${ }^{103}$. Únicamente la evolución del norte de la Galia sigue interpretándose en términos de crisis y retraimiento ${ }^{104}$.

Sin embargo, en lo que respecta a la caracterización de la estructura socioeconómica del centro-sur de la Galia (el área de incumbencia de esta tesis), el panorama historiográfico ha sufrido menos modificaciones de las que pudiera aparentar. La tendencia continuista se refleja tanto en obras de síntesis general sobre la región ${ }^{105}$ como en análisis de tipo sociopolítico ${ }^{106}$. Se halla asimismo en estudios de historia socioeconómica no centrados específicamente en la Galia que sin embargo parten del presupuesto de un fuerte quiebre en el orden económico desde c. 400 (con hincapié en la idea de descenso demográfico y retracción productiva y comercial) ${ }^{107} \mathrm{y}$ del debilitamiento de las estructuras del Estado ${ }^{108}$.

Tendremos oportunidad de atender a los matices que diferencian a los distintos historiadores. No obstante, se concibe a grandes rasgos la emergencia hacia el bajo imperio de una sociedad dividida tajantemente entre una aristocracia opulenta que concentra la propiedad territorial y una masa de campesinos dependientes, ya sean esclavos o libres desde el punto de vista jurídico (excepción hecha de los fiscalistas) ${ }^{109}$.

\footnotetext{
${ }^{101}$ Le Glay 1975, 275-285.

${ }^{102}$ Delaplace 2001, 19.

${ }^{103}$ Guyon 2001, 578.

${ }^{104}$ Devroey 2002, 112-113.

105 Geary 1988; Lebecq 1990.

${ }^{106}$ Van Dam 1985; Werner 1998.

${ }^{107}$ Ward Perkins 2000a y 2000b. Pero nótese con respecto al mercado que Loseby (1998 y 2000) ha defendido recientemente la tesis de Pirenne sobre la vitalidad del comercio mediterráneo hasta $c .700$ a través del estudio de caso de los intercambios canalizados a través del "gran puerto" marsellés.

${ }^{108}$ Heather 2000.

${ }^{109}$ Los trabajos de Bloch ([1947]) y Bonnassie (1991) contienen referencias específicas a la pervivencia de la esclavitud en la Galia. Samson (1992) estudió especialmente la región, planteando que el debilitamiento de las estructuras estatales afectó el mantenimiento del sistema esclavista durante el siglo
} 
La progresiva marginalidad del campesino propietario resulta la lógica contracara de este proceso, cuyo motor suele verse aún en el incremento de los impuestos, a pesar de que han quedado relegadas en la actualidad las corrientes historiográficas que ponderaban el carácter opresivo del aparato fiscal desde su reforma con Diocleciano. Finalmente, no se observa para la región centro-sur de la Galia una solución de continuidad hacia el siglo VI.

\section{PLANTEAMIENTO DEL PROBLEMA}

Esta tesis doctoral intentará demostrar que a partir de mediados del siglo V la región del centro-sur de la Galia experimentó una crisis profunda en la que comenzaron a generarse tendencias evolutivas que encontrarían un desarrollo incontestado en el siglo VI. La región al norte del Loira, que, como hemos señalado, comenzó hacia mediados del siglo IV un proceso de declinación que acentuó su diferenciación con el área meridional quedará excluida de nuestro análisis.

Escasean las fuentes para el estudio que nos proponemos. El historiador dedicado a estos temas debe recurrir habitualmente a modelos y comparaciones interregionales que complementen la escasa información brindada por la documentación. A menudo, las conclusiones no pueden superar el terreno hipotético. En nuestro caso, el análisis del siglo $\mathrm{V}$ hará hincapié fundamentalmente en el $D e$ gubernatione Dei de Salviano de Marsella, una obra que atribuye la decadencia del imperio a factores de índole social y religiosa, aunque detrás del tono moralizante de su autor puede percibirse la realidad socioeconómica de la Galia del periodo. Para su mejor comprensión será necesario el contrapunto con otras fuentes relativamente contemporáneas, entre las que se destacan los escritos de Sidonio Apolinar, y con los datos provenientes del registro arqueológico. Si bien la documentación legal presenta para este periodo ciertas limitaciones debidas al alcance geográfico de las disposiciones promulgadas por los emperadores, resulta también una valiosa fuente de información.

El periodo comprendido entre finales del siglo $\mathrm{V}$ y las primeras décadas del siguiente -límite cronológico de este estudio- está mejor documentado en este sentido,

V. MacMullen (1987, 368-370), en cambio, subestima la presencia de esclavos entre los galos, particularmente en las explotaciones rurales. 
si bien los datos se encuentran frecuentemente en cuentagotas, como en los escritos de Ruricio de Limoges (a caballo de ambos siglos), Avito de Vienne y Cesáreo de Arlés. La obra de Gregorio de Tours, quien escribió hacia fines del siglo VI, constituye una fuente inestimable de información, aunque deberá estudiársela con cuidado para un apropiado uso retrospectivo. Para el periodo que se inicia a fines del siglo V contamos además con documentación jurídica más apropiada en relación a los objetivos de este trabajo, pues podemos delimitar con mayor precisión el alcance geográfico de las leyes promulgadas en los reinos germánicos. Será de nuestro particular interés el código burgundio, vigente grosso modo en la región de la Galia aquí estudiada. Finalmente, es valiosa la información proveniente de los concilios de la Iglesia, reunidos con mayor frecuencia en el siglo VI que en el anterior.

Propondremos una interpretación rupturista que tenga en cuenta las críticas positivas hechas a la historiografía anclada en una concepción más tradicional sobre la "decadencia" interna de Roma. Reafirmaremos no solo el trascendental rol que jugaron las invasiones bárbaras en la crisis del mundo romano, sino el hecho de que fueron las propias limitaciones estructurales de la sociedad romana las que impidieron hacer frente al enemigo externo. Lógicamente, estas limitaciones ya estaban presentes en el siglo IV, a pesar de la "restauración". Ambas cuestiones serán analizadas en sendos capítulos iniciales sobre la crisis político-militar del imperio y sobre la transformación del Estado en el periodo posterior a la anarquía militar del siglo III, los cuales darán el marco necesario para la comprensión de la situación de la Galia del centro-sur en torno al 440.

Con la crisis y desintegración del Estado imperial se resquebrajan las bases tradicionales del poder político y socioeconómico de la elite. Esta afirmación entraña evidentemente una impugnación a las corrientes historiográficas actualmente hegemónicas que subrayan su continuidad. No hablamos de colapso, término quizás más apropiado para señalar el derrotero de Britania, pues efectivamente las aristocracias galo-romanas conservaron cuotas de poder local, monopolizando los cargos episcopales y asociándose con los últimos representantes del gobierno imperial o, luego, con los reyes germánicos ${ }^{110}$. Pero los fundamentos sociales de ese poder local fueron endebles; obispos y condes comenzarían a verse progresivamente obligados a establecer

${ }^{110}$ Wickham 2005, 175-176. 
relaciones de reciprocidad con sectores campesinos independientes, ajenos a su esfera de dominación social directa ${ }^{111}$.

Una lectura superficial del De gubernatione Dei podría llevarnos al equívoco en que han caído algunos, de suponer una extensión inusitada de la gran propiedad aristocrática y de las relaciones de dependencia. Esta es una verdad parcial. En la Galia del centro-sur, el sistema fiscal funcionaba más o menos adecuadamente para c. 440 (aunque como veremos, ya se encontraba en crisis), generando prácticas evasivas en el ámbito rural que consistían en la protección por parte de poderosos locales a campesinos propietarios. La dinámica del vínculo concluía en ocasiones en la pérdida de la propiedad y la dependencia personal, lo que ha tendido a verse como una prueba de la fabulosa acumulación territorial en manos de la elite. Sin embargo, procesos contrarios, tendientes a cierta "liberación" del campesinado, comenzaron a tomar fuerza en ese mismo periodo. El propio Salviano indica que muchos evadieron las cargas fiscales huyendo, hecho que se relaciona con los datos sobre fugas de coloni que se reiteran en las leyes. Otras fuentes escritas ofrecen indicios de dificultades a la hora de la subordinación de la mano de obra dependiente, mientras que la arqueología ha demostrado un claro retroceso de las villae, el avance de nuevas pautas de asentamiento rural $\mathrm{y}$, en términos generales, un progresivo empobrecimiento material general. Estas tendencias evolutivas cobrarán un verdadero impulso recién en el siglo VI.

Un punto fundamental para la comprensión del proceso estará dado por la crisis del aparato recaudador, que en nuestra opinión se inicia en el momento de mayor presión sobre los contribuyentes, durante la primera mitad del siglo V. Esa coyuntura estuvo marcada para el gobierno imperial de occidente por una dinámica fatídica: la constante necesidad de financiamiento para presentar batalla en los distintos frentes que se abrían fue cada vez más difícil de satisfacer en la medida en que los fracasos en dicha empresa redundaban en la pérdida de territorios, es decir, de población que tributaba. Un acontecimiento de cardinal importancia en este devenir estuvo dado por la perdida de África, la fuente de ingresos más importantes en materia fiscal ${ }^{112}$. El hecho tuvo repercusiones inmediatas en todo occidente, como demuestra la legislación de Valentiniano III $^{113}$. En este escenario, cobra verosimilitud el testimonio de Salviano

\footnotetext{
${ }^{111}$ Astarita (2007) ha planteado esto haciendo hincapié en el caso español.

112 Nuevamente debe descartarse el caso del norte galo, donde la contracción quizás pueda pensarse a partir de dificultades precoces por parte del Estado para instrumentar cobros más elevados y regulares.

${ }^{113}$ Nov. Val., 15.1 .
} 
(amén de sus ribetes dramáticos) sobre el peso excesivo de los impuestos en la Galia y sus consecuencias, en particular la de la huida como forma de evasión de aquellos desgraciados que no podían acudir a la protección de un poderoso. Pero si este fue el principal origen del proceso de conflictividad social caracterizado por la fuga y la rebeldía (de campesinos propietarios, esclavos y coloni), su dinámica no se vio interrumpida por la crisis del aparato fiscal, ya perceptible en la segunda mitad del siglo V luego de ese momento álgido.

A partir de entonces, fue ganando progresivamente terreno en el centro-sur de la Galia un modo de producción campesino en detrimento de las formas tradicionales de explotación (fiscal y a través de la renta privada). Su expansión permite hablar de sociedad de base campesina para el siglo VI. En este sentido, deberá tenerse presente la diferencia anteriormente señalada entre "modo de producción" y "formación económico-social". El matiz no es menor, pues creemos que recién en el siglo VI la dominación aristocrática se encuentra en una posición marginal respecto a la totalidad. El origen de este orden de cosas estuvo en el lento proceso de relajación de las relaciones de dominación: la crisis de los vínculos de explotación tradicionales, dada no solo por la desestructuración del aparato fiscal, sino también por la rebeldía y huida de esclavos y colonos frente a sus señores, vio la emergencia de una sociedad con patrones similares a los descritos. No obstante, la fuerte salvedad que debe hacerse en este sentido es el de la pervivencia durante el periodo analizado de formas residuales (pero concretas) de poder aristocrático. 


\section{LAS INVASIONES GERMÁNICAS Y LA CAÍDA DEL ESTADO IMPERIAL EN LA GALIA}

Este capítulo intentará exponer de manera sucinta los acontecimientos políticomilitares ocurridos en la Galia desde los inicios del siglo $\mathrm{V}$ hasta la caída del imperio romano de occidente. Como es lógico suponer, no se podrá comprender acabadamente este proceso sin atender a un contexto geográfico más amplio, en la medida en que el imperio constituía una unidad administrativa centralizada cuyas políticas regionales estaban supeditadas a las necesidades del conjunto. Por lo tanto, el desarrollo oscilará entre las referencias específicas a la Galia, el centro de nuestro interés, y las más globales a la pars occidentis en su conjunto.

Pero antes de comenzar el análisis es pertinente hacer una aclaración con respecto a la terminología que emplearemos en relación a quienes invadieron el imperio en el periodo analizado. Salvo algún caso puntual, utilizaremos las expresiones "bárbaro" y "germano" de manera más o menos indistinta a lo largo de esta tesis. En cierto sentido, hubiera sido prudente renunciar al uso del segundo de los términos, que puede conllevar la idea errada de que vándalos, suevos, godos, etc. eran pueblos unidos por un origen y un destino comunes ${ }^{114}$. Pero la tarea del historiador es también resignificar los conceptos. Creemos que es posible continuar denominando "germanos" a pueblos que no solo tenían una lengua común, sino que también compartían para esta

${ }^{114}$ Goffart 2006, 4. 
época unas similares estructuras políticas, económicas y sociales ${ }^{115}$. Debemos mencionar finalmente que ni los hunos -en cuya particularidad en relación a sus vecinos bárbaros nos detendremos brevemente más adelante- ni los alanos eran germanos.

\section{PROLEGÓMENOS}

\section{Adrianópolis}

Para entender los acontecimientos político-militares que signaron el siglo $\mathrm{V}$ en la Galia debemos remontarnos al último cuarto de la centuria anterior y a una geografía muy distinta: el curso del río Danubio en los Balcanes. Allí, en el año 376, un grupo de godos (los tervingios) cruzó la frontera del imperio romano. Dos años más tarde, ambos pueblos se enfrentaron en Adrianópolis, con la secuela de una aplastante derrota para el ejército imperial que además costó la vida de un emperador. Hasta esa fecha los romanos habían logrado mantener el control en sus relaciones fronterizas con los germanos mediante una combinación de diplomacia y represión militar, luego del intervalo abiertamente conflictivo de la segunda mitad del siglo III $^{116}$. Se había tenido que recurrir eventualmente a las armas para doblegar a francos y alamanes, pero, como plantea Peter Heather, la batalla de Adrianópolis inauguró un prolongado proceso de pérdida del control militar romano sobre su propio territorio que culminaría en la desaparición de la propia estructura política ${ }^{117}$.

Lo antedicho no equivale a sostener que la suerte del imperio haya estado echada a partir de ese momento. La crítica actual se apresura en atacar como teleológicas a las posturas historiográficas que intentando rastrear los orígenes de los procesos en busca de sus causas explicativas profundas ponderan determinados hechos en función de los acontecimientos históricos posteriores. Pero es precisamente este el proceder que debe tomar el académico si no se desea incurrir en la apología de la contingencia como motor de la historia. Con este tipo de postura parece coquetear un historiador como Guy Halsall al "inspirarse" en los planteos de Hayden White. Según el primero, la historia

\footnotetext{
${ }^{115}$ Véase Heather 2010, 57-180.

${ }^{116}$ Wood 1998, 516. Para los conflictos del siglo III, véase e. g. Carrié y Rousselle 1999, 94-105 y 161169.

${ }^{117}$ Heather 2006, 194-195 y 546-550.
} 
(story) de los años 376-476 se despliega como la disyunción entre las intenciones y los resultados de la acción social; el fin del imperio de occidente habría sido provocado entonces por gente que a menudo pretendió hacer lo opuesto. Nuestro interés, en cambio, está menos en narrar unos hechos históricos de manera tal de no producir en el lector la "sensación de ser arrastrado con violencia hacia un fin inevitable" (esa es la opinión de Halsall), que en explicar las razones por las cuales se produjeron determinados hechos y procesos en un marco estructural dado ${ }^{118}$.

Las fuentes coinciden en señalar a los hunos como los responsables del desplazamiento de los godos hacia la frontera danubiana, aunque la impresión que ofrecen de un avance espasmódico y brutal distorsiona la realidad ${ }^{119}$. Estos nómadas habrían trasladado paulatinamente sus operaciones de pillaje y pastoreo desde las estepas orientales al norte del Mar Caspio hacia occidente, primero avanzando sobre los alanos -nómadas al igual que ellos- y finalmente sobre los greutungos y tervingios, asentados al norte del Danubio. Al ver restringido su espacio vital, y frente al serio peligro que representaban las correrías de un ejército huno muy bien entrenado para tales efectos, los godos solicitaron auxilio al imperio.

En consecuencia, en el verano de 376 el entonces emperador Valente debió acceder a que los tervingios, comandados por Alavivo y Fritigerno, se asentaran en Tracia a cambio de ayuda militar, pues el grueso del ejército imperial se hallaba ocupado en el frente oriental con los persas. Las escasas fuerzas disponibles en los Balcanes no alcanzaron más que para detener el cruce del otro grupo godo que había solicitado asilo, el de los greutungos ${ }^{120}$. De tal modo, ingresaron en el territorio imperial probablemente unos 15 a 20 mil soldados, lo que supondría una población total del orden de las 90 mil personas ${ }^{121}$.

Lejos de significar una solución a los problemas vigentes, la entrada de estos germanos dio origen a una serie de conflictos con el imperio que derivaron en una crisis político-militar que tuvo un capítulo destacado en la batalla de Adrianópolis, cuyas

\footnotetext{
${ }^{118}$ Halsall 2007, 167-169. De cualquier forma, el análisis de la caída del imperio que realiza este autor es muy perspicaz en muchos puntos y lo retomaremos oportunamente en nuestra exposición.

${ }_{119}$ E. g. Amm. Marc., 31.2.1 y ss.; Zos., 4.20.3-7. Para una crítica de las fuentes, véase Heather 1995, 611 .

${ }^{120}$ Heather 2006, 213-214. Para otra interpretación véase Curran 1998, 95, que siguiendo a las fuentes (Amm. Marc. 31.4, 31.5, 31.8; Zos., 4.20.5) sostiene que el gobierno imperial dio su beneplácito al cruce de los godos.

${ }^{121}$ Halsall 2007, 175; Curran 1998, 98.
} 
secuelas para el imperio fueron desastrosas ${ }^{122}$. A mediano plazo, la consecuencia de la derrota fue un cambio en las relaciones entre las autoridades romanas y las ahora federadas tropas godas. El imperio no pudo en adelante reprimir satisfactoriamente los motines de los germanos, que parecen haber tenido como motivo principal la búsqueda de mejores condiciones para los soldados y no el asentamiento territorial. Su reticencia a cumplir con su parte de los acuerdos que implicaban una prestación militar radicaba en buena medida en que ello iba en desmedro de la base de su propio poder ${ }^{123}$.

Por primera vez en su historia, entonces, Roma se vio obligada a establecer un tratado con un pueblo germánico en términos distintos de los de una clara superioridad. Historiadores como Walter Goffart han querido ver aquí un cambio voluntario de política exterior por parte del imperio, que en un cálculo racional, y con el vivo recuerdo del alto coste que había significado la supresión de las invasiones del siglo III, habría optado por pactar con los bárbaros luego de la batalla de Adrianópolis (un experimento que "terminó yéndosele de las manos", como señalásemos en el capítulo anterior $)^{124}$. El hecho de que el tratado de paz del 3 de octubre de 382 fuese presentado como una rendición goda vela la efectiva relación de fuerzas entre ambos ejércitos. El acuerdo no consistió en instalar prisioneros ni en aceptar el establecimiento a cambio del pago de impuestos, como habían sido los anteriores. Los godos se asentaron luego de una aplastante victoria en el campo de batalla en términos en principio claramente favorables, aunque no hubiesen conseguido todas sus pretensiones. Se les asignaron tierras y suministros. Además, cuando consideraron que esos términos ya no les eran favorables, reanudaron los conflictos con la consecuencia última del saqueo de Roma (410) y de un nuevo pacto de asentamiento en Aquitania (419). La "ayuda" militar goda no consistía simplemente en la continuidad del suministro de reclutas para los ejércitos regulares sino en la prestación de auxilio por parte de tropas que estaban bajo las órdenes de jefes godos ${ }^{125}$. Por primera vez también, Roma establecía una alianza con un ejército federado establecido dentro del imperio ${ }^{126}$.

\footnotetext{
${ }^{122}$ Se calcula que murieron entre 15 y 30 mil miembros del ejército oriental, entre los que se contaron muchos oficiales (Curran 1998, 101; Kulikowski 2007, 127). Amiano Marcelino (31.13.19) consideró esta batalla como la peor derrota romana desde Canas, en 216 a. C.: "Nec ulla annalibus praeter Cannensem pugnam ita ad internecionem res legitur gesta".

${ }^{123}$ Liebeschuetz 1990, 51-67; Heather 2006, 274-279.

${ }^{124}$ Goffart 1980, 33-35 y n. 53; Goffart [1981], 15-17.

${ }^{125}$ Heather 2006, 240-243.

${ }^{126}$ Liebeschuetz 1990, 32-35.
} 


\section{Los bárbaros y el ejército romano durante el siglo IV}

La presencia de germanos en el interior del imperio no fue, sin embargo, una novedad de fines del siglo IV. El ejército romano se había estado nutriendo de ellos desde hacía mucho tiempo, reclutándolos para campañas puntuales como tropas autónomas y como parte del ejército regular.

Las tropas extranjeras se convirtieron por primera vez en una fuerza de peso en el periodo de la tetrarquía y especialmente con Constantino. Durante los siglos II y III, el ejército había estado constituido principalmente por los hijos de soldados y habitantes de las provincias en las cuales estaban estacionadas las unidades. Estas zonas, especialmente la frontera del Rin, quedaron seriamente dañadas en el siglo III, y si bien continuó existiendo la tendencia a heredar la profesión militar, hubo que recurrir a otras fuentes de reclutamiento. Esto explica el asentamiento voluntario y forzoso de laeti, dediticii y otros grupos bárbaros que brindaron servicio militar ${ }^{127}$. Se ha planteado que este proceso habría afectado particularmente a Bélgica y Germania, regiones que habían sufrido una importante caída de la población y cuyas villae habían entrado en crisis ya en el siglo III $^{128}$. En el panegírico pronunciado en honor de Constancio en Tréveris (Trier) en el año 297, por ejemplo, se indica la conveniencia de estos grupos para el cultivo de las tierras de las Galias ${ }^{129}$.

Los germanos en particular fueron cobrando relevancia en el ejército en el transcurso del siglo IV. Algunos llegaron incluso a puestos del más alto rango, como es el caso de Silvano, franco que llegó a ser magister peditum durante el gobierno de Constancio II y que se rebeló contra este proclamándose emperador ${ }^{130}$. El caso más resonante es con seguridad el de Estilicón, quien determinó la política seguida por la corte de occidente durante la minoridad y juventud del augusto Honorio ${ }^{131}$. Pero la diferencia fundamental en cuanto a la utilización de tropas bárbaras en las épocas alto y bajo imperial no residió en la cuantía, sino en que en este último periodo los romanos y los no romanos sirvieron conjuntamente en las mismas unidades, en lugar de que los

\footnotetext{
${ }^{127}$ Demougeot [1970]; Whittaker [1982]; de Ste. Croix 1988, 594-606; Liebeschuetz 1990, 11-20; Carrié y Rousselle 1999, 639-640.

${ }_{128}$ Whittaker y Garnsey 1998, 280-282 y 290; Halsall 1992.

${ }^{129}$ Pan. Lat., 8(4).21.1.

${ }^{130}$ Amm. Marc., 15.5. Otros ejemplos fueron los de Merobaudo, Bauto y Arbogasto en el último cuarto del siglo IV (O’Flynn 1983, 1-13).

131 Aunque era "semibarbarus" (Oros., 7.38), pues era hijo de una romana y de un vándalo que había hecho a su vez carrera en el ejército imperial. Sobre Estilicón, véase Mazzarino 1942.
} 
extranjeros combatieran separadamente en las unidades auxiliares. Es cierto que continuaron existiendo las tropas federadas, pero el cambio debió de contribuir seguramente a una mayor fluidez en los intercambios culturales ${ }^{132}$.

En consecuencia, tanto en el ejército como en áreas específicas del territorio imperial, la convivencia entre romanos y germanos ya era algo corriente con anterioridad al comienzo de las invasiones. Por otro lado, no debemos excluir la continuidad de la presencia de germanos (y otros bárbaros) en la masa de esclavos y campesinos con estatuto de coloni, como se desprende por ejemplo de una ley del año $409^{133}$.

\section{LAS INVASIONES A LA GALIA}

Pese al duro golpe suministrado a los romanos en Adrianópolis, los años 382405 transcurrieron pacíficamente en cuanto a las relaciones fronterizas, con excepción de un ataque huno en 395 y de las incursiones que los vándalos realizaron en la provincia de Recia durante el invierno del año 401 al 402. En dicho periodo, el gobierno imperial se había abocado a disciplinar a los godos y a asegurar la frontera oriental ${ }^{134}$. A comienzos de siglo, la Galia se encontraba en condiciones de contener apropiadamente

\footnotetext{
132 Jones 1964, 619-623; Liebeschuetz 1990, 22; Lee 1998, 222-223; Blockley 1998, 412-413.

${ }^{133}$ La ley establecía que un contingente recientemente sometido de esciros y de hunos sería puesto a disposición de aquellos ciudadanos que necesitaran poner en cultivo sus tierras. Serían asignados a título individual en calidad de coloni, con todas las obligaciones que esto comportaba a quienes así lo solicitaran mediante petición formal a la corte imperial (C. Th., 5.6.3: "Scyras barbaram nationem maximis chunorum, quibus se coniunxerunt, copiis fusis imperio nostro subegimus. Ideoque damus omnibus copiam ex praedicto genere hominum agros proprios frequentandi, ita ut omnes sciant susceptos non alio iure quam colonatus apud se futuros nullique licere ex hoc genere colonorum ab eo, cui semel adtributi fuerint, vel fraude aliquem abducere vel fugientem suscipere, poena proposita, quae recipientes alienis censibus adscriptos vel non proprios colonos insequitur. Opera autem eorum terrarum domini libera utantur ac nullus sub acta peraequatione vel censui... acent nullique liceat velut donatos eos a iure census in servitutem trahere urbanisve obsequiis addicere, licet intra biennium suscipientibus liceat pro rei frumentariae angustiis in quibuslibet provinciis transmarinis tantummodo eos retinere et postea in sedes perpetuas collocare, a partibus Thraciae vel Illyrici habitatione eorum penitus prohibenda et intra quinquennium dumtaxat intra eiusdem provinciae fines eorum traductione, prout libuerit, concedenda, iuniorum quoque intra praedictos viginti annos praebitione cessante. Ita ut per libellos sedem tuam adeuntibus his qui voluerint per transmarinas provincias eorum distributio fiat").

${ }^{134}$ Sobre la urgencia de la protección de la frontera con Persia, en el contexto de reconstrucción del ejército oriental, véase Heather 2006, 488-490. Era muy importante para el gobierno proteger Libia y Egipto, dos regiones cruciales desde el punto de vista fiscal.
} 
a los tres grupos bárbaros que estaban asentados en la frontera renana: sajones, francos y alamanes ${ }^{135}$.

Pero antes de referirnos al ciclo de invasiones debemos dar cuenta de la evolución de la política interna del imperio y de la aparición de una autoridad centralizada entre los descendientes de tervingios y greutungos. Esa autoridad estuvo encarnada en Alarico, que surgió como líder tras el fallecimiento de Teodosio en 395, en lo que supuso una violación del tratado de paz que en 382 había establecido, entre otras cosas, que los godos no podían tener un general propio. La muerte del emperador también originó la fragmentación del gobierno romano: Honorio fue reconocido como emperador de occidente, mientras que su hermano Arcadio heredó el poder en oriente. Los godos se lanzaron entonces al pillaje de los Balcanes hasta que dos años más tarde lograron arrancar a las autoridades en Constantinopla un nuevo acuerdo por el que se asentarían en Dacia y Macedonia, se reconocería a Alarico como general de Roma y, probablemente, se les concedería un estipendio ${ }^{136}$.

En la corte occidental el poder pasó a manos de Estilicón, magister militum al que teóricamente Teodosio había encargado el cuidado de sus hijos ${ }^{137}$. Pero Arcadio, en cambio, se sustrajo a sus pretensiones sobre oriente, o más bien quedó a merced de los poderosos locales, como Rufino en un comienzo. Sobrevendrían conflictos entre ambas partes del imperio con el problema godo como telón de fondo. En 397 el comes y magister utriusque militum de África, Gildo, se rebeló contra el poder en occidente al proponer que su provincia pasara a depender de Constantinopla. Pero Estilicón logró sobreponerse rápidamente a la crisis que supuso el cese del flujo de grano africano a Roma: reprimió exitosamente la revuelta a través del hermano de Gildo, Mascezel (a quien luego eliminó), llegó a un entendimiento con el senado de occidente e incluso mejoró su posición en la corte casando a su hija con el aún joven Honorio. En 401-402 logró asimismo neutralizar la invasión de Alarico a Italia. Su posición no sufrió mayores problemas hasta $406^{138}$.

Entre los años 405 y 408, una serie de incursiones bárbaras quebraron la línea defensiva desde el Rin hasta la cadena de los Cárpatos. La primera no se dio hacia la Galia, sino hacia Italia. En 405 un rey godo pagano llamado Radagaiso condujo un

\footnotetext{
${ }^{135}$ Elton 1992, 167-168.

${ }^{136}$ Heather 1991, 193-199; Wolfram 1990, 143-146; Liebeschuetz 1990, 57-59.

${ }^{137}$ Claud., In Ruf., 2.4-6.

${ }^{138}$ Matthews 1975, 257-269; Jones 1964, 182-184; O'Flynn 1983, 36-42; Blockley 1998, 113-115.
} 
contingente de compatriotas desde la llanura húngara hasta el norte de la península, cruzando los Alpes. Fue derrotado el 23 de agosto de 406 en Fiesole por tropas al mando de Estilicón. La segunda se produjo probablemente el último día del año $406^{139}$, esta vez sí sobre la Galia, cuando contingentes de vándalos -hasdingos y silingos-, suevos y alanos cruzaron la frontera renana ${ }^{140}$. La tercera tuvo lugar en el este, en 408 , cuando el huno Uldino -antiguo aliado del imperio- atravesó el Danubio con un contingente de compatriotas y de esciros para apoderarse del campamento de Marte. Seguramente fue derrotado a la brevedad, pues nada se sabe de él luego de dicho acontecimiento. El cuarto movimiento, finalmente, fue el de los burgundios, que para 411 habían cruzado el Rin para instalarse probablemente en la región de Maguncia, tal vez a ambos lados del limes. En conjunto, los invasores probablemente alcanzaran la cifra de varios cientos de miles ${ }^{141}$.

Interesa repasar ahora la segunda de estas incursiones, no solo porque el breve periodo entre el año 407 y el 409 estuvo signado en la Galia por las peripecias de los pueblos que cruzaron el Rin a fines del $406^{142}$, sino por las consecuencias de mediano plazo que ello conllevó. Como en el caso de tervingios y greutungos, el motor detrás de estas invasiones fue el desplazamiento del radio de acción de los hunos, que, como años atrás en los Balcanes, empujaron lentamente a estas tribus sedentarias contra la frontera del imperio ${ }^{143}$. Los invasores cruzaron el río a una altura cercana a Maguncia; primero

\footnotetext{
${ }^{139}$ Kulikowski 2000, 326-331, ha restituido la vieja hipótesis de Baynes (1922) de que el cruce ocurrió en realidad el 31 de diciembre del 405, logrando convencer a Halsall $(2007,121)$. El argumento tiene algunos elementos persuasivos. En primer lugar, porque la fuente en la que se apoya la datación, la crónica de Próspero de Aquitania, parece ser lo bastante ambigua como para admitir esta interpretación. En segundo lugar, porque Zósimo (6.3.1) vincula la toma del poder por parte de los usurpadores en Britania en 406 con la necesidad de hacer frente a la amenaza de los invasores. $Y$ en tercer lugar, porque dicha cronología explicaría más adecuadamente el accionar pasivo de Estilicón, que estuvo ocupado hasta agosto de 406 en combatir el ejército godo al mando de Radagaiso. Sin embargo, el contra argumento de Birley (2005, 455-460) parece más sólido, pues destaca las inconsistencias de Zósimo al referirse a los acontecimientos en la Galia y Britania, al tiempo que vincula las usurpaciones con la amenaza de Radagaiso, que en la primavera de 406 se encontraba en el norte de Italia, cerca de la frontera con la Galia. La historiografía en general sigue aceptando esta cronología e incluso el propio Kulikowski ha admitido ciertas dudas con respecto a su revisión $(2007,237$, n. 37). Una explicación de la supuesta pasividad de Estilicón en Heather 2006, 283-285.

${ }^{140}$ Hubo contingentes menores de sármatas e incluso de provinciales romanos de Panonia, como atestigua Jer., Ep., 123.15. Los suevos que mencionan las fuentes serían en realidad una coalición de cuados (ellos mismos un subgrupo que se desprendió de los suevos en el siglo I d. C.) y alamanes. Véase Heather 1995, 13, n. 1.

${ }^{141}$ Heather 2006, 251-257; 1995, 12-15. Téngase en cuenta que este autor fecha la invasión sobre la Galia el 31 de diciembre de 406 .

${ }^{142}$ Es curioso el topos construido sin base documental sólida alrededor del supuesto congelamiento del río. Ver Kulikowski 2000, 326; cf. Courcelle 1948, 60.

${ }^{143}$ Heather 1995, 16-19. De hecho para este autor, tanto la invasión de 376 como las de 405-408 representan dos fases de la misma crisis, provocada por la escalonada progresión occidental de los hunos.
} 
se desplazaron hacia el oeste y el norte, pasando por Tréveris, y luego se dirigieron hacia el sur para cruzar los Pirineos en 409. El primer asentamiento tendría lugar en Hispania $^{144}$.

Estos acontecimientos forzaron la toma del poder en la prefectura de las Galias por una serie de usurpadores. Las fuentes nos informan de la aparición en Britania de sucesivos golpes de mano entre el año 406 y el 407. El motivo que suele aducirse es la amenaza de grupos bárbaros invasores -en un principio los godos de Radagaiso- que para la primavera de 406 se encontraban en el norte de Italia, próximos a la frontera con la Galia ${ }^{145}$. Pero el ascenso del último de los tres usurpadores se produjo luego de las incursiones del 31 de diciembre de ese año. Se desconoce en qué momento de 407 Constantino III depuso al segundo de los pretendientes a la púrpura, Graciano. En cualquier caso, es probable que casi inmediatamente después de asumir como nuevo emperador aquel cruzara a la Galia para pelear con los bárbaros y asegurar su posición sobre bases más firmes. Tuvo rápido éxito en esto último, aunque, según Michael Kulikowski, quizás no fuera hasta la derrota del ejército imperial al mando de Saro, en la primavera de 408, que lograra un dominio sobre Provenza ${ }^{146}$.

Es probable que antes de 407 el generalissimo de occidente, Estilicón, estuviese intentando llegar a un acuerdo con el líder godo Alarico para lograr la incorporación de sus fuerzas al imperio de occidente. Según Peter Heather, el plan habría consistido en arrebatar a oriente el control del Ilírico, que tradicionalmente había pertenecido a occidente y donde estos bárbaros estaban asentados, para luego entregar legalmente estas tierras a sus actuales ocupantes a cambio de una alianza militar ${ }^{147}$. Alarico desplazó sus fuerzas a Epiro en espera de un respaldo occidental que nunca llegó. Estilicón decidió priorizar el conflicto abierto en la Galia, enviando tropas al mando del federado Saro. La expedición fue un fracaso y la posición del generalissimo se tornó inestable. Inquieto por la dilación en el ataque a oriente, Alarico trasladó sus fuerzas a la provincia del Nórico, cerca de Italia, y exigió al gobierno de Honorio el pago de 1800 kg. de oro. Se suscitó a continuación una controversia entre el senado romano, propenso

\footnotetext{
${ }^{144}$ Hyd, Chron., 49; Oros., 7.43.14.

${ }^{145}$ Aunque recientemente se ha planteado que podrían existir razones puramente locales (la falta de paga de la soldada) para la primera de las usurpaciones, la de Marco (Sanz Huesma 2005). Para Kulikowski $(2000,332)$ la corrección en la fecha de la segunda de las invasiones permite relacionar la primera usurpación con el cruce del Rin, como explícitamente indica Zósimo (6.3.1).

${ }^{146}$ Drinkwater 1998, 275-279; Kulikowski 2000, 333-334.

${ }^{147}$ Heather 1991, 211-213.
} 
a presentar batalla a los godos, y Estilicón, que era de la opinión de que había que atender los reclamos del general germano para no abrir otro frente de batalla. La intención última del generalissimo era probablemente enviar a Alarico a atacar a Constantino III $^{148}$.

Estilicón logró salirse con la suya, pero su posición era débil. Olimpio, un alto funcionario de la corte que había sido designado por aquel, intrigó para profundizar la brecha que comenzaba a abrirse entre el generalissimo y el emperador Honorio. En mayo de 408 fallecía Arcadio, dejando a su hijo Teodosio II la púrpura de oriente. Olimpio acusó entonces a Estilicón de tramar el derrocamiento de este último con el objetivo de colocar a su hijo Euquerio como emperador y el rumor se difundió por las tropas. La suerte estaba echada; el generalissimo fue ejecutado en agosto de dicho año. Pronto corrió igual suerte su hijo y Honorio se divorció de su hija.

Olimpio se autoproclamó magister officiorum y quedó al mando de los asuntos de occidente. Esto produjo una alteración en la política de la corte. Los godos estaban ahora en una situación precaria, instalados temporalmente en tierras que no les eran familiares, aunque probablemente su número había crecido a treinta mil hombres con la recepción de soldados bárbaros que habían sido reclutados por Estilicón y de esclavos fugados (probablemente ambos grupos pertenecían a los godos de Radagaiso). Alarico avanzó entonces hacia Italia, saqueando los territorios que atravesó de camino a Roma. Una vez llegado a destino, sitió la ciudad eterna y no se retiró hasta que el senado hubo accedido al pago de un rescate en metales, sedas, pieles y especies. Pero Honorio, a instancias de Olimpio, no estaba dispuesto a ratificar el acuerdo. Esta política constituyó a todas luces un error y significó el ocaso de este último. Parte de las tropas godas fueron emboscadas en Pisa y como represalia Alarico decidió volver a Roma y reanudar sus exigencias. Hubo varias idas y vueltas que implicaron la elección de Prisco Atalo como emperador por parte del senado y con el consentimiento de Alarico. El poder de Honorio tambaleó, pero logró mantenerse a flote gracias al apoyo militar de la corte oriental y la lealtad de las provincias africanas. Consiguió entonces neutralizar a Atalo (a quien, a su vez, Alarico quitó apoyo), pero persistió en su política de no negociar con los godos. A la intransigencia del emperador, Alarico respondió con el saqueo de Roma $^{149}$.

\footnotetext{
${ }^{148}$ Zos., 5.31 .

${ }^{149}$ Matthews 1975, 270-300; Heather 2006, 287-294; Liebeschuetz 1990, 64-68; Blockley 1998, 122-128.
} 
No obstante, este sería el último de los logros del líder godo. Con posterioridad al saqueo, Alarico y sus hombres se dirigieron al sur de Italia. Probablemente el propósito que tenían en mente era invadir el norte de África, pero cuando aguardaba para cruzar a Sicilia el general murió. En su reemplazo fue elegido su hermano Ataúlfo, quien cambiaría de estrategia como veremos. Mientras tanto, se abriría ahora una coyuntura de cierta estabilidad para el gobierno de occidente con el ascenso de Flavio Constancio al antiguo cargo de Estilicón, el de magister militum. Quizás fuera un antiguo partidario de este último. En cualquier caso, Constancio maniobró con éxito para ganarse el favor del emperador e imponer como prioridad del momento el avance sobre el usurpador Constantino III, a quien finalmente derrotó. Fijemos la atención ahora en los asuntos de la Galia desde $406^{150}$.

Constantino parece haber logrado llevar a buen puerto su relación con parte de los bárbaros que estaban dentro de la Galia y en las zonas fronterizas. Con los francos, que habían aprovechado los disturbios para avanzar sobre la frontera, renovó acuerdos o estableció otros nuevos, consistentes en ayuda militar que se patentizó en el auxilio prestado por estas fuerzas en el enfrentamiento con Saro ${ }^{151}$. Probablemente también intentara realizar pactos con quienes habían protagonizado la invasión de 406/407, aunque fracasó en este frente ${ }^{152}$.

También logró suprimir con éxito -a través de su hijo Constante- una revuelta que en Hispania habían provocado fuerzas leales al emperador Honorio. La reconstrucción tradicional de los hechos -basada en un problemático pasaje de Zósimopropone que la península se rebeló ante el avance del usurpador. Sin embargo, esto se contradice con el planteo de Orosio de que en un primer momento los hispanos habían aceptado los iudices enviados por Constantino ${ }^{153}$. Para Drinkwater, debe darse crédito a esta última fuente. En su opinión, el reconocimiento hacia el régimen del usurpador por parte de los hispano-romanos siguió el derrotero de anteriores tomas de poder en la región; el grueso de las fuerzas de la prefectura estaba en la Galia, de modo que lo más lógico para los hispanos era aceptar a Constantino. Solo cuando se supo de la expedición al mando de Saro, a comienzos del año 408, sectores ligados a la casa

\footnotetext{
${ }^{150}$ Jones 1964, 186-187; Heather 2006, 303-304 y 307.

${ }^{151}$ Zos., 6.2.4.

152 Drinkwater 1998, 282.

${ }^{153}$ Oros., 7.40.5; Zos., 6.4.1-2.
} 
teodosiana se levantaron contra un régimen que hasta entonces había logrado consenso $^{154}$.

Si en un determinado momento Constantino corrió el riesgo de quedar encerrado entre dos frentes enemigos, el año 409 se inició de forma auspiciosa para el nuevo emperador. La amenaza que, como hemos visto, estaba representando Alarico para la corte de Ravena, posicionó de forma inmejorable a Constantino de cara a Honorio; en efecto, este último se vio obligado a reconocerlo como su colega ${ }^{155}$.

Sin embargo, la estabilidad interna del régimen sería efímera. En el verano de 409 se produjo un alzamiento en Britania, esta vez quizás fundamentado en la necesidad de la población local de defenderse de los invasores sajones ante la incapacidad de las autoridades romanas de hacerlo por ella ${ }^{156}$. Al mismo tiempo, se produjo en Hispania un nuevo levantamiento contra Constantino, esta vez por iniciativa de Geroncio, magister militum a cargo de Hispania tras la supresión de la anterior revuelta ${ }^{157}$. Las razones son objeto de discusión. Matthews plantea que la insurrección se dio como consecuencia del cruce de los Pirineos por parte de las tribus que hasta el momento habían estado castigando a los galos, hecho que los hispanos habrían interpretado como una desprotección por parte del nuevo régimen. Pero Drinkwater propone que Geroncio se habría distanciado de Constantino con motivo de la voluntad del usurpador de retirar efectivos de Hispania para hacer frente a su proyecto de extender su dominio hacia Italia. En definitiva, esto habría empujado a Geroncio a invitar a las fuerzas invasoras a cruzar los Pirineos para sellar un pacto de alianza militar con el cual presionar a Constantino para cambiar de política. Kulikowski apoya esta reconstrucción y propone además que las devastaciones registradas por Jerónimo en el sur de la Galia datarían de esa fecha y no del momento inmediatamente posterior al cruce del Rin ${ }^{158}$. El pacto finalmente no se selló y los bárbaros pudieron cruzar a una Hispania desguarnecida y dedicarse al pillaje ${ }^{159}$.

El intento de Constantino III de extender su dominio a Italia fracasó, del mismo modo que lo hicieron las dos expediciones punitivas enviadas a Hispania al mando de

\footnotetext{
${ }^{154}$ Drinkwater 1998, 280.

${ }^{155}$ Olymp., fr. 13.1; Zos., 5.43.2. Matthews 1975, 310; Kulikowski 2000, 337.

${ }^{156}$ Zos., 6.3.3; Birley 2005, 459.

${ }^{157}$ Soz., HE, 9.13; Olymp., fr. 17.1; Oros., 7.42.4-5.

158 Matthews 1975, 311; Drinkwater 1998, 283-284; Kulikowski 2000, 337-338.

159 Oros., 7.40.9.
} 
su hijo Constante, quien colocado como lugarteniente, encontraría allí la muerte ${ }^{160}$. En 411, Geroncio y Máximo, a cargo nominalmente del nuevo gobierno hispano con sede en Tarraco, invadieron la Galia con el auxilio de un ejército federado de bárbaros, aunque su arribo fue seguido por el de las fuerzas imperiales conducidas por los generales Constancio y Ulfila ${ }^{161}$. Recordemos que hasta ese momento Honorio había tenido que enfocarse en el conflicto abierto con Alarico, pero una vez aliviado dicho frente, el gobierno de occidente se vio libre para emprender la recuperación del control de las provincias usurpadas. El proceso tuvo inicio en esta campaña exitosa contra Constantino III, que además incluyó el suicidio de Geroncio, abandonado por sus propias tropas ${ }^{162}$.

El desenlace inmediato de estos episodios fue, no obstante, una nueva usurpación, probablemente cuando el general Constancio se encontraba en Ravena. Un senador de nombre Jovino se autoproclamó emperador probablemente en Maguncia ${ }^{163}$. Construyó una base de poder relativamente sólida durante dos años, fundamentada en una alianza con los burgundios y los alanos, asentados ahora en territorio romano a la altura del Rin medio, en el auxilio potencial de los godos -que permanecían en el sur de Italia desde el saco de Roma a la espera de un acuerdo militar, como hemos visto-, y casi con seguridad en el consenso de sectores aristocráticos galos, temerosos de que les cayera una represalia por haber apoyado el régimen anterior. Posiblemente el nuevo usurpador lograse controlar buena parte de la Galia. Pero uno de esos pilares en los que se apoyaba fue menos sólido de lo que parecía y, paradójicamente, terminó convirtiéndose en causa de la caída del régimen. Jovino había pactado una alianza con Ataúlfo no solo para acrecentar su propia base militar, sino para evitar un posible entendimiento entre este y Honorio. Sin embargo, fue precisamente esto lo que ocurrió al poco tiempo de ingresar los godos en territorio galo. Ataúlfo se alió entonces con el prefecto de la Galias Dárdano, que actuó como representante local de la corte de Ravena, traicionando de ese modo el acuerdo con Jovino. Con los godos en contra, su régimen ya no tenía esperanzas ${ }^{164}$.

\footnotetext{
${ }^{160}$ Soz., HE, 9.12.5-6; Olymp., fr. 15.1, 17.1.

161 Soz., HE, 9.13.1; Olymp., fr. 17.1. Es probable que Ulfila fuese magister equitum praesentalis o magister equitum per Gallias; de todas formas no vuelve a ser mencionado luego de este episodio (O’Flynn 1983, 64).

${ }^{162}$ Soz., HE, 9.13.4-7; Kulikowski 2000, 338-340; Heather 2006, 303-305.

163 Olymp., fr. 18.

${ }^{164}$ Matthews 1975, 313-315; Drinkwater 1998, 287-292. Contra la opinión de este último, Halsall (2007, 223) considera que la falta de documentación sobre el régimen de Jovino y el hecho de que su dominio no
} 
En consecuencia, hacia el verano de 413 se logró reunir por primera vez en siete años a los principales ejércitos del imperio occidental bajo un mismo mando, el de Constancio. De todos modos, esto no significó la estabilización de la situación políticomilitar en la Galia, pues una revuelta liderada por Heracliano en África había interrumpido el suministro de la principal fuente fiscal dejando al imperio sin granos para poder dar abasto a los godos ${ }^{165}$. Ataúlfo mostró su disconformidad rápidamente. Atacó Marsella, tomó Narbona, Toulouse y Burdeos y se casó con Galla Placidia, hermana de Honorio, a quien los godos habían raptado en el saqueo de Roma ${ }^{166}$. Sin embargo, el gobierno romano supo rectificar el contexto adverso a tiempo. Constancio recuperó el control de Narbona, donde se habían instalado los bárbaros, y estableció un bloqueo terrestre y naval que obligó a estos a trasladarse a Barcelona en busca de provisiones; allí no tuvieron mejor suerte ${ }^{167}$. Producto de estos reveses, se sucedieron golpes de mano internos que en el verano de 415 culminaron con el ascenso de Wallia como líder único. El bloqueo naval continuó, generando el hambre entre los bárbaros. A comienzos de 416 se estableció finalmente un pacto entre godos y romanos, que entrañó la entrega de trigo por parte de los segundos a cambio de ayuda militar por parte de los $\operatorname{primeros}^{168}$.

La Galia dejó de ser teatro de operaciones militares importantes a partir del año 414, aunque la paz no se prolongaría por mucho tiempo. La evaluación del saldo material de estos conflictivos años depende en buena medida de lo que nos han transmitido autores que a menudo buscaban provocar la conmoción de los lectores; muchos de ellos redactaron sus escritos inmediatamente después de los acontecimientos.

Jerónimo escribe desde Belén y antes de cerrado el periodo que venimos de analizar. Envía en 409 una carta a Ageruchia, una viuda gala, aconsejándole que no se case. En un pasaje se refiere a las "miserias presentes" que vive la Galia a raíz de los saqueos y destrucciones provocados por las distintas tribus invasoras. Enumera distintas ciudades del noreste por donde han pasado los bárbaros e indica que Aquitania,

se expandiera sobre Britania e Hispania debilitan la tesis de un apoyo aristocrático generalizado al régimen.

${ }^{165}$ Oros., 7.42.10. Heracliano pasó a Italia pero fue derrotado por los lugartenientes de Constancio. Huyó a Cartago y poco después fue asesinado allí.

${ }^{166}$ Olymp., fr. 24; Oros., 7.40.2; Hyd., Chron., 57 (año 414).

${ }^{167}$ Prosp., Chron., 1256 (año 415); Oros., 7.43.1-3.

${ }^{168}$ Burns 1992, 54-55; Matthews 1975, 316-318; Heather 1991, 219-224. 
Lugdunense y Narbonense han quedado desoladas con excepción de unas pocas ciudades $^{169}$. El tono es claramente exagerado, pero Jerónimo parece informado, pues señala que Hispania aún no ha sufrido las invasiones y está al tanto de las acusaciones contra Estilicón ${ }^{170}$.

Una serie de poemas escritos en la Galia poco después del periodo analizado se refieren a las invasiones y sus consecuencias. Se trata del Epigramma Paulini, atribuido a Paulino de Béziers; del Carmen ad Uxorem, de Próspero de Aquitania; del Carmen de Providentia Dei, probablemente también escrito por este último y del Commonitorium, de Orencio de Auch. Las obras tocan temas similares y probablemente fueron escritos para las mismas audiencias y en el mismo medio ${ }^{171}$. Sería ocioso reproducir pormenorizadamente la forma en que cada poema se refiere a los estragos causados por el paso de los bárbaros. Serán suficientes algunos ejemplos puntuales. En el Carmen de Providentia Dei, la ruina provocada por las incursiones bárbaras aparece como algo peor que una inundación oceánica, pero las analogías con las catástrofes naturales se entremezclan con referencias más concretas a saqueos de cosechas y ganado y destrucción de edificios rurales y urbanos ${ }^{172}$. Algo similar puede decirse de la reconstrucción de Orencio de Auch que sintetiza el impacto del paso de los bárbaros en una frase frecuentemente evocada: "uno fumavit Gallia tota rogo"173. Paulino de Béziers, describe vívidamente los pillajes de vándalos y alanos; lo interesante de su obra es el pasaje en el que se queja de aquellos que en lugar de dedicarse a hacer una

\footnotetext{
169 Jer., Ep., 123.16: "Praesentium miseriarum pauca percurram. Quod rari hucuscue residemus, non nostril meriti, sed Domini misericordiae est. Innumerabiles et ferocissimae nations universas Gallias ocuparunt. Quidquid inter Alpes et Pyrenaeum est, quod Oceano et Rheno includitur, Quadus, Wandalus, Sarmata, Halani, Gipedes, Heruli, Saxones, Burgundiones, Alemani, et, o lugenda respublica! Hostes Panonii vastarunt. Eterim Assur venit cum illis. Moguntiacum, nobilis quondam civitas, capta atque subversa est, et in Ecclesia multa hominum millia trucidata. Vangiones longa obsidione deleti. Remorum urbs praepotens, Ambiani, Attrebatae, extremique hominum Morini, Tornacus, Nemetae, Argentoratus, translate in Germaniam. Aquitaniae, Novemque populorum, Lugdunensis, et Narbonensis provinciae, praeter paucas urbes populata sunc cuncta. Quas et ipsas foris glaudius, intus vastas fames. Non possum absque lacrymis Tolosae facere mentionem, quae ut hucusque non rueret, sancti Episcopi Exuperii merita praestiterunt. Ipsa Hispaniae jam jamque periturae, quotidie contremiscunt, recordantes irruptionis Cimbricae, et quidquid alii semel passi sunt, illa semper timore patiuntur".

${ }^{170}$ Jer., Ep., 123.17: "Quod non vitio Principum, quid vel religiosissimi sunt, sed scelere semibarbari accidit proditoris, qui nostris contra nos opibus armavit inimicos"; Courcelle 1948, 62-63.

${ }^{171}$ Roberts 1992.

${ }^{172}$ Carm. de prov. Dei, 8-90. La atribución de la autoría del poema a Próspero de Aquitania se discute. Su fecha de composición probablemente date de 416 (Markovich 1989, ix).

${ }^{173}$ Orient., Comm., 2.165-202 (cita textual en 2.184).
} 
evaluación de su comportamiento moral a la luz de los tiempos que se viven, se dedican a reconstruir sus casas ${ }^{174}$.

Otro testimonio no es dado pocos años después de los acontecimientos por un aristócrata oriundo de la Galia pero residente en Roma. En el cuadro de situación trazado por Rutilio Namaciano en su De Reditu Suo se percibe una genuina preocupación por el futuro económico de la región, a pesar del tono en general optimista del poema:

los campos de la Galia reclaman a su paisano [él mismo], desfigurados -cierto es- por guerras harto largas, pero tanto más dignos de conmiseración cuanto menos atractivos. Pequeño delito es descuidar a los conciudadanos si viven seguros, pero las calamidades que sufre la comunidad reclaman la lealtad individual. Las lágrimas por las moradas de nuestros ancestros debemos derramarlas estando allí presentes: la enseñanza que se obtiene del dolor hace a menudo provechosa la reconstrucción, y no es lícito seguir ignorando las ruinas que se han acrecentado por la tardanza de un socorro que va demorándose. Es ya tiempo, destrozadas nuestras heredades tras largos incendios, de edificar al menos cabañas de pastores ${ }^{175}$.

Otros dos testigos presenciales dejaron registro de sus vivencias con bastante posterioridad a los hechos. Por un lado tenemos a Paulino de Pella, quien se refiere en su Eucharisticos (c. 460) a las acciones provocadas en sus propiedades aquitanas por los godos de Ataúlfo, que estuvieron instalados transitoriamente en Burdeos en 414. El poema es interesante porque Paulino da cuenta allí de que muchos estaban floreciendo bajo los godos. Esto estaría hablándonos de que parte de la aristocracia continuaba con un tren de vida similar al que tenían bajo los romanos ${ }^{176}$. Sin embargo, el autor menciona que en el momento de su retirada los godos saquearon propiedades e

\footnotetext{
${ }^{174}$ Epig. Paul., 8-41. Para el autor del poema, las luchas recientes con los bárbaros sirven de contrapunto a la lucha espiritual que cada cristiano debe dar contra las fuerzas pecaminosas. No se sugiere que las invasiones sean un castigo por el pecado como en el De gubernatione Dei de Salviano, pero los recientes eventos aparecen como un incentivo para el mejor comportamiento, dada la transitoriedad de las posesiones materiales (Roberts 1992, 98).

${ }^{175}$ Rut. Nam., De red. suo, 1.19-30: "At mea dilectis fortuna revellitur oris, / indigenamque suum Gallica rura vocant. / Illa quidem longis nimium deformia bellis, / sed quam grata minus, tam miseranda magis. / Securos levius crimen contemnere cives: / Privatam repetunt publica damna fidem. / Praesentes lacrimas tectis debemus avitis; / prodest admonitus saepe dolore labor; / nec fas ulterius longas nescire ruinas, / quas mora suspensae multiplicavit opis: / iam tempus laceris post saeva incendia fundis / vel pastorales aedificare casas".

${ }^{176}$ Paul. Pell., Euch., 305-307.
} 
incendiaron la ciudad, de modo que no fueron pocos los romanos damnificados ${ }^{177}$. Finalmente, Salviano -oriundo del norte galo- se refiere en su De gubernatione Dei al itinerario seguido por los vándalos tras la invasión de 406, dando cuenta de los estragos que provocaron ${ }^{178}$, a la vez que describe vívidamente las devastaciones sufridas por Tréveris ${ }^{179}$.

Pierre Courcelle reunió estos documentos en un libro que vio la luz tres años después de finalizada la Segunda Guerra Mundial ${ }^{180}$. El crédito que otorga a esos relatos puede haber estado influenciado por la experiencia reciente del autor. Historiadores posteriores plantearon objeciones a esa lectura, señalando que la reconstrucción de los autores antiguos ensombrecía una realidad mucho menos trágica con fines retóricos (unos fines cuya existencia Courcelle reconocía). Ian Wood, por ejemplo, ha insistido en la supervivencia casi sin daños de la aristocracia de la Galia central y meridional durante el siglo V. Estos escritos se entenderían entonces como creaciones cuyo estilo y forma estaba determinado por estrategias literarias de los distintos autores. Así, por ejemplo, mientras los escritos de los moralistas asociados con el universo monacal (Orencio, Salviano) tendieron a acentuar las rupturas con el pasado preocupados como estaban por insuflar valores culturales y espirituales nuevos, los escritores de fines del siglo $\mathrm{V}$, como Sidonio, se propusieron enfatizar la continuidad cultural con el mundo de la anterior centuria ${ }^{181}$.

Pero tal vez debamos otorgar cierto crédito a estos autores. Es importante tener en cuenta el medio en el cual escribieron, el público para el que lo hicieron y los objetivos que se plantearon. Pero planteos como el de Wood conllevan el riesgo de eludir la solución al problema de la evaluación de los acontecimientos reales. Los dichos de Paulino de Pella referidos al buen pasar de muchos habitantes de Burdeos en el momento que escribía su poema o la preocupación de Paulino de Béziers por aquellos

\footnotetext{
${ }^{177}$ Paul. Pell., Euch., 233-241 ("Sed transacta aevi post trina decennia nostri / succesit duplicis non felix cura laboris, / publica quipped simul clade in commune dolenda / hostibus infuses Romani in viscera regni / privata cum sorte patris de funere functi: / ultima namque eius finitae tempora vitae / temporibus ruptae pacis prope iuncta fuere. / At mihi damna domus populantem inlata per hostem, / per se magna licet, multo leviora fuere / defuncti patris immodico conlata dolori, per quem cara mihi et patria et domus ipsa fiebat"); 286-290 ("quod post eventu cessit non sero sinitro, / null out quipped domum speciali iure tuente / cederet in praedam populo premissa abeunti: / nam quosdam scimus summa humanitate Gothorum / hospitibus studuisse suis prodesse tuendis") y 311-314 ("Namque profecturi regis praecepto Atiulfi / nostra ex urbe Gothi, fuerant qui in pace recepti, / non aliter nobis quam belli iure subactis / aspera quaeque omni urbe inrogavere cremata").

${ }^{178}$ Salv., De gub. Dei, 7.12.50-53.

${ }^{179}$ Salv., De gub. Dei, 6.82-84.

${ }^{180}$ Courcelle 1948, 57-88.

${ }^{181}$ Wood 1992.
} 
que estaban ocupándose de la reconstrucción de sus casas obligan a descartar una lectura catastrofista. Pero tampoco parece que se trate meramente de un constructo retórico sobre una realidad apenas perturbada, sobre todo si pensamos que fueron alrededor de cien mil los bárbaros que invadieron la Galia y se dedicaron durante un tiempo considerable a una economía del saqueo ${ }^{182}$. El paso de Alarico por Italia a comienzos de siglo fue lo suficientemente importante como para forzar al imperio a decretar una enorme rebaja impositiva en la provincia ${ }^{183}$. Que no tengamos disposiciones similares para la Galia meridional podría atribuirse menos a que el impacto de las incursiones bárbaras fuese allí poco significativo, como al hecho de que una corte necesitada de financiamiento probablemente encontrara preferible reducir la carga sobre las tierras de la aristocracia italiana antes que sobre las de la gala, que además había estado recientemente implicada en el sostenimiento de usurpadores. Finalmente, es probable que en ciertas regiones el paso de los bárbaros contribuyera a trastocar los lazos tradicionales de dependencia ${ }^{184}$.

Los hechos descritos constituyen los primeros pasos de un proceso en espiral caracterizado esencialmente por: (a) pérdidas materiales como consecuencia inmediata de las guerras y los saqueos, acompañadas de (b) una exigencia creciente de financiamiento por parte del Estado a sus contribuyentes. La compleja dinámica de este último fenómeno requiere una atención pormenorizada, de modo que dedicaremos a su tratamiento un capítulo aparte. Adelantemos, sin embargo, que la base fiscal se fue contrayendo progresivamente, no solo por la pérdida de territorios, sino porque las devastaciones forzaban a menudo al imperio a posponer los cobros como en el caso que hemos mencionado anteriormente. En consecuencia, aquellas regiones que no habían sufrido directamente el paso de los germanos acarreaban ahora sobre sus espaldas mayores presiones por parte del Estado. Los romanos de Hispania que preferían huir

\footnotetext{
${ }^{182}$ La cantidad es objeto de discusión. Goffart (1980, cap. 1) tiende a minimizarla, pero Drinkwater (1998, 274-275), en cambio, ha planteado que si bien en un comienzo probablemente los contingentes invasores no fueran importantes en número, a medida que progresaron en su avance debieron de acrecentarse con nuevos reclutas y dependientes. Sobre las dificultades para establecer la cuantía a partir de las fuentes disponibles, véase Wood 1998, 521-522. La cifra que referimos es propuesta por Heather 2006, 258.

${ }^{183}$ C. Th., 11.28 .7 (413) y 11.28 .12 (418).

${ }^{184}$ Nixon 1992, 69. Sabemos que en distintas regiones se unieron a los ejércitos bárbaros esclavos y desarraigados (Zos., 5.13, 5.42).
} 
hacia las huestes enemigas lo hacían, según Orosio, para no pagar los impuestos. La misma situación se presenta unas décadas después en la Galia, según Salviano ${ }^{185}$.

\section{DEL ASENTAMIENTO GODO}

\section{A LA PÉRDIDA DE ÁFRICA}

La primera prestación militar que hicieron los godos a continuación del pacto sellado con la corte imperial de occidente fue en las provincias hispanas. Los bárbaros que habían cruzado los Pirineos en 409 se repartieron la región, con la excepción de Tarraconense, que quedó en manos de las autoridades tradicionales. Las campañas contra los vándalos y los alanos fueron aparentemente exitosas y como consecuencia de ello Constancio ofreció a los godos instalarse en Aquitania ${ }^{186}$. El carácter de este asentamiento -como los de los otros pueblos germánicos- será analizado con mayor detenimiento en el próximo capítulo ${ }^{187}$.

Pero poco después de iniciarse la tercera década del siglo $\mathrm{V}$ una crisis interna delicada, relacionada con problemas sucesorios, quebró la relativa estabilidad que había logrado el imperio occidental. En 421 murió Constancio. El general había logrado un enorme poder en el seno de la corte de Honorio, pasando a ser quien de facto guiaba el rumbo del gobierno. En 417 se incorporó a la familia teodosiana al casarse con Galla Placidia, que había sido liberada por Wallia como parte de su acuerdo con los romanos $^{188}$. Dos años más tarde nacería su hijo, Valentiniano, y ocho meses antes de morir Constancio fue incluso elevado al rango de augusto. Su política fue relativamente exitosa. Eliminó a los usurpadores de la Galia y logró un acuerdo con los godos que implicaba su empleo contra otros bárbaros, una estrategia que había sido perseguida por Teodosio y Estilicón ${ }^{189}$.

\footnotetext{
185 Oros., 7.41.7: "quamquam et post hoc quoque continuo barbari exsecrati gladios suos ad aratra conuersi sunt residuosque Romanos ut socios modo et amicos fouent, ut inueniantur iam inter eos quidam Romani, qui malint inter barbaros pauperem libertatem, quam inter Romanos tributariam sollicitudinem sustinere"; Salv., De gub. Dei, 5.5.21.

${ }^{186}$ Kulikowski 2004, 166-167; Halsall 2007, 228.

${ }^{187}$ No resulta sencillo encontrar un punto a partir del cual comenzar a llamar "visigodo" a este pueblo. Optamos aquí por a utilizar el término a partir del asentamiento de 419 porque esa fue la base del posterior reino visigodo, aunque la denominación no se generaliza sino posteriormente.

${ }^{188}$ Olymp., fr., 30 y 34. Aparentemente la hermana de Honorio era reluctante a casarse con Constancio (Olymp., fr. 33.1).

${ }^{189}$ O’Flynn 1983, 71.
} 
La desaparición de escena de Constancio provocó un vacío que no pudo ser llenado por Castino, quien fracasó en la campaña que estaba llevando contra los vándalos en Hispania. En 423 moría además Honorio, dejando en principio a Teodosio II como único emperador romano. El pequeño Valentiniano III se encontraba desde hacía menos de un año exiliado en Constantinopla junto a su madre por decisión de aquel $^{190}$. El deceso de Honorio desató entonces una serie de conflictos políticos que debilitaron coyunturalmente a la corte de occidente. Ante la ausencia de Teodosio y de Valentiniano, un alto funcionario civil, usurpó el trono. Juan fue declarado emperador con el apoyo de Castino y de Aecio -en ese momento cura palatii-, pero sin el de Bonifacio, comes Africae. Su gobierno duraría poco. Teodosio decidió elevar a su sobrino al rango de césar y envió una expedición militar que terminó con la ejecución de Juan, el exilio de Castino y el arreglo con Aecio, cuando este se disponía a avanzar junto con sus aliados hunos. En octubre de 425 Valentiniano III fue proclamado finalmente augusto ${ }^{191}$.

Los conflictos con las fuerzas extranjeras se reavivaron como consecuencia de la crisis interna que sobrevino a la muerte de Constancio. Los visigodos violaron rápidamente el tratado acordado con las autoridades imperiales (cualquiera haya sido su carácter), atacando en varias ocasiones el sur de la Galia. En Hispania, vándalos, suevos y alanos retornaron a las expediciones de pillaje de los primeros años de las invasiones. Las primeras incursiones de los visigodos se realizaron sobre Arlés, entre los años $425 \mathrm{y}$ 430, pero fueron suprimidas exitosamente por Aecio, quien luego de pactar su subordinación a la casa teodosiana había sido nombrado magister militum per Gallias $^{192}$. El general también se sobrepuso a los frentes abiertos por los francos en 421 o $422^{193}, 428$ y $432^{194}$ y por los jutungos y los nóricos en 430 y $431^{195}$. Sin embargo, el panorama era sombrío. Para 435 Britania ya se había perdido definitivamente; Hispania y el norte de la Galia parecían estar gobernadas por líderes locales bajo títulos romanos y por guerreros bárbaros; Numidia y Mauritania habían sido cedidas oficialmente a una

\footnotetext{
${ }^{190}$ Olymp., fr. 38.

${ }^{191}$ Heather 2006, 331-334; Halsall 2007, 234-237; Blockley 1998, 135-136.

192 Prosp., Chron., 1290 (año 425); Chron. Gall. a. CCCCLII, 102 (año 427); Hyd., Chron., 92 (año 430).

193 Greg. Tur., Hist., 2.9 (el autor parafrasea aquí a Renato Profuturo Frigerido).

194 Prosp., Chron., 1298 (año 428); Hyd., Chron., 98 (año 432). No queda claro de cuántas campañas se trata en estos últimos dos casos y en los dos referidos a los visigodos. Para Heather $(2000,7)$ fueron dos contra cada uno de ambas tribus, pero Halsall $(2007,237)$ cree que fue solo una. Nuevamente nos enfrentamos al problema de cotejar las crónicas entre sí.

${ }^{195}$ Chron. Gall. a. CCCCLII, 106 (año 430); Hyd., Chron., 93 (año 430) y 95 (año 431).
} 
coalición de vándalos y alanos, luego de que estos invadieran África en 429 liderados por Genserico. Este último acuerdo, conseguido gracias a la acción de las fuerzas orientales comandadas por Aspar, buscaba proteger Proconsular y Bizacena, regiones claves desde el punto de vista fiscal. En otras palabras, probablemente dos tercios del imperio occidental se encontraban fuera del control directo del gobierno central al promediar la década de $430^{196}$.

Tras la asunción de Valentiniano III la autoridad militar de occidente estuvo repartida entre Aecio, Bonifacio y Félix, magister utriusque militum y patricius. La situación de virtual empate entre ellos no se modificó en 427, cuando el último maniobró sin éxito contra el segundo, sino a partir de 430. Ese año Aecio mandó arrestar y posteriormente ejecutar a Félix. Luego libró batalla contra Bonifacio, quien a pesar de hacerse con la victoria resultó mortalmente herido. El cargo de este último fue heredado por Sebastiano. Aecio debió huir con los hunos, con quienes mantenía una amistad que se retrotraía a los años en que conviviera con ellos en calidad de rehén, pero tuvo un regreso triunfal en 433 , cuando con la ayuda de estos logró desplazar a Sebastiano, quien debió exiliarse en Constantinopla. La posición de líder indiscutible de occidente se coronó en 435 con la adopción del título de patricio ${ }^{197}$.

Los frentes de conflicto en la Galia continuaron abiertos. Entre los años 435 y 439, las fuerzas imperiales debieron medirse en el campo de batalla contra bagaudas, burgundios, francos y visigodos ${ }^{198}$. Se trató de batallas de carácter defensivo que fueron llevadas a buen puerto (aunque la derrota de Litorio de 439 frente a los visigodos constituye una notable excepción), pero que no lograron revertir en ningún momento el contexto frágil en el que se encontraba el imperio desde inicios del siglo V. Para hacer frente a los problemas en la región, Aecio recurrió al socorro de los hunos, al precio de entregarles los territorios situados a lo largo del río Sava en Panonia ${ }^{199}$. El hecho demuestra tanto la habilidad del general como la fragilidad de sus recursos, si bien es cierto que este expediente ya había sido utilizado por Constancio en sus campañas de $411^{200}$. Contra las bagaudas de Armórica también se valió del apoyo de los alanos, a

\footnotetext{
${ }^{196}$ Halsall 2007, 240-243; Heather 2006, 364-365.

197 O'Flynn 1983, 77-81; Heather 2006, 365-366.

198 Hyd., Chron., 107-108 (año 436), 110-112 (años 437-438) y 116 (año 439); Prosp., Chron., 1322 (año 435), 1324 (año 436), 1326 (año 437), 1333 (año 438) y 1335 (año 439); Chron. Gall. a. CCCCLII, 117 (año 435), 118 (año 436) y 119 (año 437).

${ }_{199}$ Priscus, fr. 11.1 .

${ }^{200}$ Heather $1995,25$.
} 
quienes asentó en tierras fronterizas de las regiones de Orleans y de Valencia (Valencesur-Rhône) en $440^{201}$. Los hunos colaboraron concretamente en la durísima derrota inflingida a los burgundios en 436 y en las campañas contra los visigodos ${ }^{202}$. Por su parte, en Hispania la posición de los romanos tuvo una aparente mejora, aunque gracias al accionar de los propios provinciales antes que de los funcionarios de la corte. Desembarazados de la ocupación vándala y alana tras el éxodo comandado por Genserico, los hispanos lograron permanecer en paz con los suevos, instalados en el noroeste hasta el año $438^{203}$.

Algunos autores como Hugh Elton, han sobreestimado en nuestra opinión el grado de control imperial de la situación política en la Galia en el periodo posterior a al año 420, fundamentando su argumento en las victorias del ejército romano en distintos frentes, tanto sobre germanos como sobre rebeldes internos ${ }^{204}$. Esto supone una confusión entre triunfos militares y control efectivo del territorio. La periodicidad de las campañas contra los francos en el noreste de la región, por ejemplo, revela hasta qué punto Roma no era capaz de imponerse una vez que se retiraba del campo de batalla. La serie de éxitos militares de la era de Aecio no fue suficiente para revertir la vulnerabilidad del gobierno imperial, aun cuando gracias a la obra de ese gran estratega se pudo mantener un mínimo orden interno, incluso después de la pérdida de África. En cuanto a la Galia, la extensión del territorio bajo dominio imperial se redujo considerablemente en dicho periodo, por lo que resulta desacertado hablar de "estabilidad".

Vale la pena repasar con cierto detenimiento el alcance de esta contracción. Como acabamos de decir, el gobierno central ya no era capaz de desplegar un auténtico control sobre el noreste de la región, limitándose a enviar ejércitos cuando la situación se tornaba inquietante ${ }^{205}$. A las ya referidas victorias sobre los francos, hay que agregar otra en 446 o 448, que tampoco logró resolver los conflictos ${ }^{206}$. Los saqueos se sucedían y ciudades como Colonia ya habían quedado sometidas directamente al dominio bárbaro $^{207}$. El hecho de que el autor de la Crónica gala del año 452 se refiriese al

\footnotetext{
${ }^{201}$ Chron Gall. a. CCCCLII, 117 (año 440) y 127 (año 441/442).

202 Prosp., Chron., 1322, 1326 y 1335; Hyd., Chron., 116 (año 436).

${ }^{203}$ Kulikowski 2004, 179-180.

${ }^{204}$ Elton 1992, 169-72.

${ }^{205}$ Wightman 1985, 304-305.

${ }^{206}$ Sid., Carm., 5.212-254 (año 458).

${ }^{207}$ Salv., Ep., 1.5-6.
} 
territorio situado al norte del Loira como Gallia Ulterior ha sido interpretado como un signo de que ya no era considerada parte integrante de los dominios de Roma ${ }^{208}$. Para comienzos de la década de 460 las autoridades occidentales dejarían incluso de enviar expediciones punitivas, abandonando a su suerte la región ${ }^{209}$.

El noroeste, por su parte, tuvo una evolución distinta pero con similar resolución para el imperio. No sabemos a ciencia cierta cuándo aparecieron las bagaudas en el Tractus Armoricanus. Durante mucho tiempo se pensó que los versos dedicados por Rutilio Namaciano a su pariente Exuperantio, quien había logrado devolver la paz a las costas de la región, hacían referencia a una primera campaña punitiva por parte del imperio $^{210}$. Posteriormente se descartó por vaga esta última información, quedando como primera manifestación de la existencia de las bagaudas en nuestras fuentes las referencias de las crónicas a las campañas contra Tibatón en 435-437 y como última las del año $448^{211}$. La alusión de Zósimo a bagaudas en los Alpes en 407 resulta aislada y por el momento no nos ocuparemos de las que tuvieron lugar en Hispania ${ }^{212}$. Trataremos el tema con mayor profundad más adelante, pero cabe señalar aquí que aunque no se señalen como bagaudas, tenemos otros datos de grupos rebeldes en la región armoricana, no solo en la referencia ofrecida por Rutilio Namaciano sino en una de las crónicas que menciona la existencia de oposición armada por parte de los habitantes despojados con motivo del asentamiento alano ${ }^{213}$. Por otro lado, no sabemos hasta qué punto la región estuvo a merced de los sajones, a quienes fuentes posteriores muestran realizando incursiones de saqueo desde Britania ${ }^{214}$. En cualquier caso, queda patente que el gobierno central fue teniendo cada vez mayores dificultades para mantener su dominio en la región y cómo fue disminuyendo, a la vez, su interés por poner en cintura a la región noroccidental conforme pasaba el tiempo y se presentaban problemas más urgentes en áreas prioritarias.

Finalmente, la región aquitana se hallaba con toda seguridad bajo el control pleno de los visigodos para 440. Guy Halsall ha analizado recientemente este periodo a

\footnotetext{
${ }^{208}$ Chron. Gall. a. CCCCLII, 127 (año 441/442); Halsall 2007, 248.

${ }^{209}$ Elton 1992, 172.

${ }^{210}$ Rut., De red. suo, 1.213-216 (“Cuius Aremoricas pater Exuperantius oras / nunc postliminium pacis amare docet; / leges restituit libertatemque reducit / et servos famulis non sinit esse suis"); Thompson [1952], 346-347.

${ }^{211}$ Chron. Gall. a. CCCCLII, 133 (año 448); Const., V. Ger., 28 y 40. Drinkwater 1992, 209-210.

${ }^{212}$ Zos., 6.5.3.

${ }^{213}$ Chron. Gall. a. CCCCLII, 127 (año 441/442).

${ }^{214}$ Sidonio señala que los visigodos habían estado protegiendo la costa aquitana de los ataques de piratas sajones (Ep., 8.6.13-15, c. 480).
} 
la luz tanto de la información documental contemporánea como de la referida a acontecimientos posteriores para proponer que el gobierno central ya no era capaz de poner gobernadores en el valle del Garona para finales de la década de 430. El tratado sellado entre romanos y visigodos en 439, luego de que finalizara la serie de ataques que estos últimos lanzaran sobre la región entre los años 436-439 sería el primero entre entidades plenamente soberanas ${ }^{215}$. Halsall se apoya para sostener esto en la política exterior seguida a continuación por Teodorico, que había sucedido a Wallia en 418, al casar a una de sus hijas con Hunerico - hijo de Genserico y, por tanto, primero en la línea sucesoria al trono vándalo- y a la otra con el rey suevo Recaredo ${ }^{216}$. El argumento resulta convincente. Por un lado, era necesaria una cierta autonomía para negociar alianzas con entidades políticas que ya eran claramente independientes (los suevos incluso estaban en guerra con los romanos desde $438^{217}$ ). Por otro lado, Roma intentó en todo momento desde el inicio de las invasiones utilizar a unos bárbaros contra otros, por lo que no habría visto con buenos ojos que tropas federadas leales en territorio propio negociaran independientemente con otros pueblos.

Pero de ninguna manera puede considerarse total la crisis de la autoridad romana en la Galia hacia el año 440. Según John Matthews, el hecho de que el concilium de las Galias no fuera un consejo compuesto por representantes de toda la región, sino solo de las Siete Provincias -los territorios del centro-sur, incluida Aquitania en un principio-, daría cuenta de un alcance limitado, pero concreto, del poder de la autoridad de Arlés $^{218}$. Es preciso recordar en este sentido, que hacia principios de siglo la sede del prefecto del pretorio se había trasladado de Tréveris a esta ciudad portuaria, probablemente en el contexto de inestabilidad política provocado por las invasiones y las usurpaciones ${ }^{219}$. La restauración política y social fue entonces más coherente en el sur, bajo la influencia política directa de la nueva capital pretoriana. Tampoco deberíamos pasar por alto datos concretos acerca de la continuidad del gobierno romano en puntos muy cercanos a la inestable región norte. Tómese como ejemplo el episodio de la Vida de San Germano de Auxerre en el cual el obispo pide al prefecto una

\footnotetext{
215 Prosp., Chron., 1338; Hyd., Chron., 117.

${ }^{216}$ Halsall 2007, 245-250.

${ }^{217}$ Kulikowski 2004, 180-186.

${ }^{218}$ Matthews 1975, 334-337.

${ }^{219}$ El concilium anual de las Galias estaba presidido por el prefecto del pretorio. En parte buscaba atraer las lealtades de las clases acomodadas hacia la nueva capital. Cabe acotar de todos modos que para Halsall $(2007,258)$, si bien inicialmente se conformó con la intención de frenar el separatismo en la región, con el tiempo el consejo terminó constituyéndose en canal para estas aspiraciones.
} 
remisión de los impuestos para su ciudad. La anécdota da cuenta de la pervivencia de las estructuras fiscales en áreas muy alejadas de Arlés ${ }^{220}$.

Finalmente, hay que insistir una vez más sobre un punto que consideramos central para comprender los cambios de mediano plazo: no se debe subestimar el impacto que todos estos conflictos militares tuvieron sobre la población civil de la Galia romana, tanto directamente -en las zonas que fueron escenario de batallas e incursiones-, como a través del incremento de la presión fiscal. La condonación solicitada por san Germano tenía que ver con la implantación de impuestos extraordinarios que resultaban muy gravosos para los locales.

\section{DE LA PÉRDIDA DE ÁFRICA}

\section{A LA CAÍDA DEL IMPERIO}

En 439 tropas al mando de Genserico invadieron las regiones africanas de Bizacena y Proconsular y se apoderaron de la ciudad de Cartago ${ }^{221}$. Este acto terminaría constituyendo un episodio fundamental para la suerte del imperio. Con la cantidad de frentes conflictivos abiertos y con el alcance geográfico del territorio que debían proteger las autoridades occidentales, la pérdida de la enorme fuente de ingresos fiscales que representaban estas regiones resultaba una herida casi mortal ${ }^{222}$. La gravedad de la crisis desatada se refleja en un puñado de leyes dictadas por Valentiniano III al calor de los hechos, tendientes a asegurar el aprovisionamiento de grano de la capital por vías alternativas, fijar una leva forzosa de soldados y eliminar las exenciones fiscales vigentes $^{223}$.

El intento por recuperar África con una avanzada combinada de fuerzas occidentales y orientales desde Sicilia fracasó por la necesidad de hacer frente en el año 441 al conflicto surgido en los Balcanes a raíz de una incursión de los hunos ${ }^{224}$. El hecho fue por otro lado aprovechado por los suevos para hacerse con el dominio de

\footnotetext{
${ }^{220}$ Const., V. Ger., 19.

${ }^{221}$ Prosp., Chron., 1339; Hyd., Chron., 115.

${ }^{222}$ Wickham 2005, 87-88; Heather 2006, 369-381; Ward-Perkins 2005, 43.

${ }^{223}$ Nov. Val., 5.1 (año 440), 6.1 (año 440), 4 (año 440) y 10 (año 441). Pero el emperador se vio obligado a decretar remisiones para la región de Sicilia, devastada por los ataques vándalos en 440 (Nov. Val., 1.2).

${ }^{224}$ Maenchen-Helfen 1973, 108-110.
} 
prácticamente la totalidad de Hispania, excepción hecha de Tarraconense ${ }^{225}$. El año siguiente se estableció un tratado entre el gobierno de occidente y Genserico mediante el cual los romanos lograban retener algunos de los territorios que habían sido cedidos en 435 , pero la situación no podía ser más desastrosa ${ }^{226}$. Los ingresos de Bizacena y Proconsular se habían perdido totalmente y el gobierno de Valentiniano se vio obligado a otorgar una reducción de 7/8 en lo que las recuperadas Numidia y Mauritania aportaban al fisco, como compensación a quienes habían sufrido expropiaciones ${ }^{227}$.

El proceso de concentración del poder que se había operado años antes entre los hunos había aumentado considerablemente sus capacidades bélicas. Con ellas cambiaron también sus aspiraciones de cara al imperio. Hasta c. 430 no habían representado una amenaza seria para los romanos, pero bajo el liderazgo de Rúa creció su poderío militar y consecuentemente su capacidad de exigir tributo al imperio. Sus sobrinos Bleda y Atila -y a partir de 445 solo este último- continuaron en esta dirección desde fines de esa década, logrando controlar a todas las tribus asentadas al norte del Danubio y el mar Negro y conformando un poderoso ejército ${ }^{228}$. Atila concentró primero sus esfuerzos en oriente, pero en 450 giró su interés hacia occidente. La razón tal vez se encuentre en que necesitaba reforzar su liderazgo con una gran victoria militar, lo cual era más probable que ocurriera si dirigía sus armas contra la debilitada pars occidentis $^{229}$. Según Prisco, Atila decidió atacar con el objetivo no solo de castigar a los romanos por haberle negado a Honoria en matrimonio, sino también a los francos por una disputa dinástica interna y a los visigodos como un favor a Genserico $^{230}$ : simples justificativos para la conquista ${ }^{231}$.

Es seductora la hipótesis que relaciona directamente los acontecimientos de fines de la década del 430 vinculados a las regiones africana y balcánica con el régimen de asentamientos en la Galia de comienzos de la siguiente. Un imperio preocupado por atender con urgencia al frente huno no podía continuar la política relativamente exitosa

\footnotetext{
${ }^{225}$ Hyd., Chron., 120 (año 440), 123 y 125 (año 441). Kulikowski 2004, 180-182.

226 Vict. Vit., Hist. persec., 1.13; Merrills y Miles 2010, 112-113. El tratado incluyó además el compromiso de casamiento entre Hunerico, hijo del rey vándalo, y Eudocia, hija de Valentiniano III. ${ }^{227}$ Nov. Val., 13.1 y 9 (445).

${ }^{228}$ Maenchen-Helfen 1973, 81-129; Whitby 2000, 704-712; Williams y Friell 1999, 61-68.

${ }^{229}$ Williams y Friell 1999, 82.

${ }^{230}$ Priscus, fr. 17; Jor., Get., 42.223-224. Aparentemente Honoria había ofrecido su mano a Atila como parte de una maniobra de venganza contra su hermano Valentinano III, que tras haber descubierto su relación clandestina con un tal Eugenio, la había prometido en casamiento a un senador.

${ }^{231}$ Clover [1973], 110-112 y 115. En su opinión, la "ayuda" brindada a Genserico escondería una tentativa de Atila por ganarse el favor de los vándalos, al menos logrando que no interviniesen en apoyo del imperio.
} 
que Aecio había puesto en práctica en la década anterior en distintos frentes. Ahora se trataba de proteger lo que restaba en plenitud bajo dominio romano, es decir, la Galia centro-meridional. Con este propósito se conformó un cinturón protector mediante la instalación de alanos y burgundios, mientras el gobierno central se abocaba a la difícil tarea de contener a los hunos y reconquistar Bizacena y Proconsular ${ }^{232}$. Se posponía entonces el proyecto de recuperación del área septentrional; las intervenciones se reducirían a las mencionadas campañas punitivas contra los francos y, probablemente, contra las bagaudas.

La Galia romana quedaba entonces relativamente al amparo de los peligros externos, pero no de la crisis fiscal interna. El presupuesto militar era financiado ahora por una base tributaria enormemente reducida. En el año 444 o 445, Valentiniano se veía obligado a reconocer que los recursos disponibles no eran suficientes para dotar adecuadamente de suministros a los reclutas ${ }^{233}$. Fue en este contexto en el cual Salviano escribió su De gubernatione Dei, texto que denuncia el insoportable peso que tenían los impuestos, particularmente sobre los contribuyentes más desamparados ${ }^{234}$.

Atila invadió la Galia en 451 a través del Rin y se dedicó al saqueo de ciudades $^{235}$. Previamente se había tomado un tiempo para emprender contactos con algunos actores de la región para poder ampliar su base militar ${ }^{236}$. Sin embargo, una vez en territorio enemigo la diplomacia del jefe huno se reveló ineficaz. No solo no logró hacerse de ningún aliado de peso, sino que en los Campos Cataláunicos el ejército romano al mando de Aecio lo esperó acompañado de una amplia coalición conformada por visigodos, alanos, francos y burgundios. Incluso parece que se les unieron armoricanos (¿bagaudas?), los restos del ejército de Britania y antiguos limitanei del $\operatorname{Rin}^{237}$. Las crónicas informan que la batalla terminó en un baño de sangre de ambos

\footnotetext{
${ }^{232}$ Halsall 2005, 49; 2007, 248.

${ }^{233}$ Nov. Val., 15.1: "Cum pietatis nostrae animo ad quaerenda remedii publici adiumenta perpetuae cogitationes se ingerant, nihil tam necessarium cura serenitatis nostrae perspicit, sicut omnium sensibus non optamus ocurrere, quam ut defessis rebus afflictoque publico, tantum robur numerosi exrcitus praeparetur; sed nec tam salubris, in qua omnium plenae securitatis fundamenta ponenda sunt, per varia erogationum clementiae nostrae conatum odoratorus, ut ipso experimento non modo his, qui novis sacramentis obligantur, sed ne veteri quidem exercitui, quae ab exhaustis aegerrime conferuntur, ad vicutm vel ad vestium posse praeberi: qous nisi indigna et pudenda armato nomini negotiatio aleret, vis possent a famis periculo et a frigorum pernice vindicari".

${ }^{234}$ Véase el capítulo 4.

${ }^{235}$ Hyd., Chron., 150 (año 451).

${ }^{236}$ Clover [1973], 113-115.

${ }^{237}$ Halsall (2007, 252-253). Jor., Get., 36.191, menciona a los armoricanos, en una lista un tanto confusa.
} 
lados, a pesar de que el imperio se alzase con la victoria ${ }^{238}$. Las maltrechas fuerzas de Atila huyeron y cuando se aprestaban a invadir Roma luego de haber saqueado varias ciudades, se vieron obligadas a regresaron al Danubio, porque otro general romano llamado también Aecio- había ingresado con tropas imperiales orientales al corazón de su imperio ${ }^{239}$.

La muerte de Atila, ocurrida poco después, en 453, desencadenó un levantamiento de los pueblos sometidos contra quienes pretendían heredar la jefatura. Para los romanos, el efecto inmediato del súbito desmoronamiento de aquel imperio fue que los hunos dejaran de ser una fuerza potencialmente utilizable contra otros bárbaros, concretamente contra quienes habían sido asentados dentro de los límites que Roma seguía reivindicando como propios. Por otro lado, la crisis política en Europa central terminó añadiendo otro factor negativo para occidente cuando, como resultado del conflicto que ahora oponía entre sí a las antiguas tribus sometidas al yugo huno, algunas huyeron en dirección del imperio romano ${ }^{240}$.

Sin la ayuda potencial de los hunos, de la cual Aecio había sabido sacar partido en ocasión de numerosas campañas, el imperio romano se encontró seriamente limitado en su capacidad de maniobrar militarmente. Hemos visto que ya en los años previos encontraba dificultades para abastecer a su ejército. Las ricas provincias de Proconsular y Bizacena no habían sido recuperadas y en el último tiempo algunas regiones solo habían tributado intermitentemente (como Hispania o África occidental). Las que seguían cumpliendo con las obligaciones, como la Galia meridional, comenzaron a sufrir los efectos de la presión fiscal ${ }^{241}$.

La muerte de Atila desató una crisis interna en la corte imperial. La posición de Aecio se había vuelto frágil desde que sus aliados tradicionales se tornasen enemigos ${ }^{242}$. Fue asesinado por el propio Valentiniano III en una maniobra orquestada por el senador Petronio Máximo, que luego de consumado el hecho inició otro complot para dar muerte al emperador y hacerse él mismo con la púrpura ${ }^{243}$. Afianzado mínimamente en el cargo, adoptó medidas forzadas por el contexto de debilidad en el que estaba inmerso

\footnotetext{
${ }^{238}$ Hidacio (Chron., 150), calcula exageradamente que 300.000 hombres dejaron la vida allí, mientras que Prospero de Aquitania (Chron., 1364) dice que las muertes fueron "incalculables". Ninguno de los dos discrimina bandos.

${ }^{239}$ Maenchen-Helfen 1973, 129-141.

${ }^{240}$ Williams y Friell 1999, 86-91; Heather 1995, 29-30 y 37-38.

${ }^{241}$ Véase el capítulo 4.

${ }^{242}$ O'Flynn 1983, 88-89, 96-97 y 100-101.

${ }^{243}$ Priscus, fr. 30.
} 
el imperio: aliarse con el reino visigodo ${ }^{244}$. El encargado de las negociaciones sería Avito, un aristócrata galo-romano que había gozado de buenas relaciones con los $\operatorname{godos}^{245}$. Pero mientras las tratativas tomaban curso, Máximo fue asesinado en medio de la confusión provocada por la invasión vándala de Roma, en $455^{246}$. Según Sidonio, el rey visigodo Teodorico II le habría asegurado a Avito su apoyo en el caso de convertirse en emperador, como muestra de cuánto había aprendido a apreciar las leyes romanas gracias a su enseñanza ${ }^{247}$. Probablemente buscase no desaprovechar la situación para fortalecer un tratado de amistad con un imperio que, pese a todo, seguía siendo respetado y que se presentaba como un potencial aliado contra otros enemigos bárbaros (en particular los vándalos) ${ }^{248}$.

La aristocracia senatorial de la Galia se alineó detrás de Avito. Se abrían nuevas perspectivas, pues desde que el emperador Graciano trasladara la corte occidental de Tréveris a Milán en 381 las aspiraciones del sector habían debido limitarse a la esfera política local $^{249}$. En cualquier caso, la experiencia duraría muy poco. A pesar de que en un principio los principales generales presentes en Italia -Mayoriano y Ricimeroparecieron dispuestos a reconocer a Avito por temor al apoyo visigodo con que contaba, la existencia de un poder rival en África, que controlaba el abastecimiento de grano a Roma, hacía necesaria la presencia permanente del emperador en las cercanías. Además, la aristocracia peninsular no estaba dispuesta a renunciar a un control de los asuntos gubernamentales que había logrado retener durante las últimas tres generaciones ${ }^{250}$. Finalmente Mayoriano y Ricimero abrieron hostilidades contra Avito, que aparentemente no había sido reconocido por Constantinopla. En el campo de batalla resultaron victoriosos los primeros. A Avito le fue concedido el episcopado de Piacenza, pero murió poco después. Así, el emperador romano de oriente se vio obligado a otorgar a Ricimero el rango de patricio y a Mayoriano el de magister militum. El apoyo oficial de Constantinopla se había tornado crucial para cualquier aspirante al trono de occidente que pretendiese contar ayuda militar oriental para

\footnotetext{
${ }^{244}$ Heather 2006, 468-475.

${ }^{245}$ Sid., Carm., 7.377-378 (año 456).

${ }^{246}$ Merrills y Miles 2010, 116-117.

${ }^{247}$ Sid., Carm., 7.495-498.

248 Sivan 1993, 138-139; Harries 1994, 75-78.

${ }^{249}$ Mathisen 1993, 18-20. Aunque en los últimos años de Aecio en el poder, algunos habían accedido a altos cargos (O’Flynn 1983, 96).

${ }^{250}$ Heather 2006, 480; Halsall 2007, 261-262.
} 
recuperar África. Luego de algunos meses de interregno, en abril de 457, Mayoriano fue elevado a la púrpura de occidente ${ }^{251}$.

Esta coyuntura fue aprovechada por los germanos asentados en la Galia. Como parte de la alianza que los había unido a Avito, los visigodos habían emprendido una expedición a Hispania para enfrentarse a los suevos, que amenazaban con hacerse con el dominio de Tarraconense, último reducto romano. La crisis palaciega en Italia les dio la oportunidad para hacerse con el botín de guerra, dedicándose al saqueo tras la victoria $^{252}$. Por su parte, los burgundios tomaron tierras cerca de Lyon, en una cesión acordada con la aristocracia local, renuente a Mayoriano ${ }^{253}$.

El futuro que se abría al nuevo emperador no era nada halagüeño. Como bien plantea Heather, solo había dos alternativas posibles de salida a la situación de inminente colapso del gobierno imperial. O bien se expandía la base fiscal o bien se reducía la cantidad de competidores al territorio imperial ${ }^{254}$. La primera alternativa suponía incrementar los impuestos, una medida prácticamente imposible de adoptar, habida cuenta de los serios problemas que estaba evidenciando el aparato recaudatorio. Mayoriano se vio obligado a condonar atrasos de los contribuyentes, lo que en este contexto podría estar indicando rebeldía fiscal ${ }^{255}$. Otras disposiciones revelan que la situación presupuestaria era grave ${ }^{256}$. Por otro lado, los conflictos bélicos seguían teniendo consecuencias sobre la producción, como probablemente ocurriera en Lyon tras la represión de la sedición de los locales en alianza con los burgundios. Sidonio solicitó al emperador un alivio en las cargas para reconstruir un país golpeado ${ }^{257}$.

\footnotetext{
${ }^{251}$ O'Flynn 1983, 105-107; Heather 2006, 493-495. Mayoriano fue proclamado por segunda vez el 28 de diciembre de ese año, seguramente porque recién en ese momento fue reconocido por el emperador León I, que había sucedido hacía poco a Marciano como emperador de oriente.

${ }^{252}$ Hyd., Chron., 174 (año 456) y 186 (año 457); Kulikowski 2004, 187-189.

${ }^{253}$ Mar. Avent., Chron., a. 456; Harries 1994, 85-86.

${ }^{254}$ Heather 1995, 34.

${ }^{255}$ Nov. Mai., 2. El texto de esta última disposición resulta bastante revelador de la capacidad de los contribuyentes para pagar los impuestos, a ojos de la administración central ("fessas provincialium varia atque multipli tributorum exactione fortunas, et extraordinariis fiscalium solutionum oneribus attritas solutae illationis amisisse substantiam, et defectum sui etiam in his, quae merito fuerant solvenda, sensisse: superindictitiis si quidem titulis in praeteritum possessor exhaustus, dum aegrae solutionis trahit sub impossibili devotione reliquias, et pro temporis cursu novis subinde perurgetur venientum indictionum tributis, et in redimendis attenuatur induciis, coacervata in unum sarcina obnoxietatis obruitur, et, praecedentibus debitis neutiquam sufficiens, ad futuram quoque illationem minus idoneus invenitur").

${ }^{256}$ Nov. Mai., 5.1, 7.1.16.

${ }^{257}$ Sid., Carm., 5.574-587 (“[580-587] telluris glaebam solidae. Bove, fruge, colono, / civibus exhausta est. Stantis fortuna latebat; / dum capitur, vae quanta fuit! post gaudia, princeps, / delectat meminisse mali. Populatibus, igni / etsi concidimus, veniens tamen omnia tecum / restituis: fuimus vestri quia causa triumphi, / ipsa ruina placet") y 13.15-26 (año 459).
} 
Mayoriano se inclinó entonces por la segunda opción. Una vez asegurado el apoyo de los senadores italianos y del ejército de federados al mando de Ricimero, adoptó una política de acercamiento con la aristocracia gala, cediéndole puestos clave de la administración regional y central $^{258}$ y en 459 logró restablecer la paz con Teodorico $\mathrm{II}^{259}$. Las energías estaban puestas ahora en la recuperación de África. Desde el verano de 458 estaba preparándose una campaña consistente en un ataque conjunto a Sicilia - parte de la cual había sido tomada por los vándalos- y a Cartago. El primero se haría desde Italia y estaría a cargo del comes Marcelino, un antiguo aliado de Aecio que tras la muerte de este había establecido una suerte de reino en la costa Dalmacia pero que ahora parecía reincorporado en la administración imperial. La expedición a Cartago implicaría el cruce al África noroccidental vía Hispania y estaría a cargo del propio emperador. Pero los preparativos cobraron estado público y se prolongaron demasiado, dando oportunidad a Genserico para planificar la defensa. Los vándalos lograron frustrar el avance de Mayoriano, quien se vio obligado a regresar a Italia. Una vez allí fue decapitado por Ricimero ${ }^{260}$. Probablemente a partir de ese momento, los jefes bárbaros tomaron la decisión de ampliar las bases territoriales de sus reinos ante la certeza de que el imperio tenía sellada su suerte ${ }^{261}$.

Ricimero había logrado eliminar a su rival en el poder y pretendía sustituirlo por una figura militarmente insignificante. Su decisión de poner en el trono a Libio Severo de cuyos orígenes poco se sabe- quizás tuviera como intención secundaria conformar a la aristocracia senatorial italiana. En cualquier caso, tanto el emperador León I como Marcelino y el magister militum per Gallias, Egidio, se negaron a reconocerlo ${ }^{262}$. Este último, aparentemente antiguo hombre de confianza de Mayoriano, decidió retirarse al norte de la Galia con sus tropas, conformadas en su mayoría por francos ${ }^{263}$. Teodorico II, que a esta altura controlaba los ejércitos apostados en Hispania consiguió arrebatar Narbona al gobierno romano a cambio del compromiso de atacar a Egidio ${ }^{264}$. La resignación por parte de Roma a tener paso libre hacia la península ibérica implicaba que cualquier acción futura sobre los vándalos debería provenir desde Italia. Por su

\footnotetext{
${ }^{258}$ Harries 1994, 88-91.

${ }^{259}$ Hyd., Chron., 197.

${ }^{260}$ Merrills y Miles 2010, 119-120; Halsall 2007, 264-265.

${ }^{261}$ Heather $1995,35$.

${ }^{262}$ O’Flynn 1983, 110-111.

263 Priscus, fr. 39.1.

${ }^{264}$ Hyd., Chron., 217. Véase el capítulo 3 sobre esta batalla y los acontecimientos posteriores.
} 
parte, el poder territorial visigodo se consolidaba ${ }^{265}$. Finalmente, los burgundios también sacaron ventaja de la coyuntura. Su rey, Gundobado, selló una alianza con el imperio que lo convirtió en magister militum per Gallias, logrando, además, la reconquista de Lyon y una expansión sobre el valle del Ródano ${ }^{266}$. De esta manera, se reducía un poco más la ya mermada base fiscal del imperio.

Libio Severo murió en 465, aparentemente de causas naturales. Se emprendieron negociaciones entre Ricimero y Constantinopla que culminaron con la asunción de Antemio en su reemplazo, tras un lapso de dos años en el cual el trono quedó vacante. Esto significaba, en principio, contar con la ayuda de las fuerzas militares orientales para la preparación de una nueva campaña contra Genserico, que esta vez estaría comandada por Basilisco, cuñado del emperador León. Halsall plantea que el ataque de los visigodos sobre los suevos pudo haber sido parte de una maniobra general tendiente a desplegar tropas hacia el África vía Hispania, aunque surgen dudas sobre si realmente a esta altura los visigodos tenían voluntad de que el imperio se reconstruyese ${ }^{267}$. De cualquier modo, la intentona volvería a resultar un fiasco ${ }^{268}$.

La lealtad de la aristocracia gala hacia el gobierno central empezaba a resquebrajarse. Tenemos evidencias de ciudades que se entregaron a los enemigos y de funcionarios romanos que se valieron del sostén bárbaro para ir en perjuicio del gobierno central $^{269}$. La lucha por el control de los asuntos políticos locales parecía empujar cada vez más a los poderosos de la región a alejarse de los intereses imperiales y negociar un entendimiento con los Estados vecinos. Que Mayoriano se viera compelido a realizar concesiones para ganar el respaldo de los poderosos de Lyon, aún cuando estaba fresco el recuerdo de la represión a los disidentes, demuestra la fragilidad de las bases locales del Estado imperial. Fundamentalmente, el vértice burocráticomilitar que controlaba el gobierno central no podía garantizar el principal aspecto funcional que lo justificaba: la protección de sus súbditos. Pese a ello, una fracción de la aristocracia gala seguiría apegada a Roma durante el gobierno de Antemio. El alineamiento se manifiesta, por ejemplo, en la obtención por parte de Sidonio de la

\footnotetext{
${ }^{265}$ Halsall 2007, 268.

${ }^{266}$ PLRE, 2, 524-525; Mar. Avent., Chron., a. 463.

${ }^{267}$ Hyd., Chron., 240; Halsall 2007, 272-274.

${ }^{268}$ Williams y Friell 1999, 173-174; Lee 2007, 105-106.

${ }^{269}$ Jor., Get., 194; Sid., Ep., 3.2.2; Conc. Angers (453), c. 4; Mathisen 1993, 77-79 y 82-83.
} 
prefectura urbana en 468 o en la de Arvando de la prefectura de las Galias (hasta que fuera acusado de traición ese mismo año) $)^{270}$.

La situación seguía siendo sumamente precaria para el imperio. Eurico, rey de los visigodos desde 466, constituía una amenaza latente sobre el territorio galo que aún se conservaba bajo dominio romano, pues al parecer tuvo como meta la expansión territorial desde su ascenso al trono ${ }^{271}$. En respuesta a su desafío, una avanzada al mando de Antemiolo, hijo del emperador, partió para hacerle frente, no sin antes intentar una negociación en la que propusieron al rey la cesión de Clermont a cambio de la Septimania ${ }^{272}$. La maniobra pretendía recuperar el paso a Hispania. De cualquier forma, Eurico rechazó el ofrecimiento y derrotó primero a las fuerzas imperiales y luego a las de Riotamo, líder de un ejército britano que supuestamente había huido del dominio sajón para buscar un modus vivendi en la Galia y que ahora era un aliado circunstancial de Roma ${ }^{273}$.

Esto permitió a Ricimero desembarazarse de Antemio con la ayuda de Gundobado $^{274}$. El poder efectivo del emperador romano de occidente se limitaba ahora a una parte muy reducida de la Galia, Italia, Nórico y Dalmacia ${ }^{275}$. Se sucedieron efímeramente un par de emperadores -Olibrio y Glicerio- hasta que a mediados de 473 Julio Nepote logró asirse al trono con el apoyo de Zenón desde Constantinopla. Para entonces el rey burgundio Gundobado, magister militum y patricio durante el breve reinado de Glicerio, había decidido que era preferible volver a la Galia para consolidar su posición interna antes que quedarse en Italia a disputar en la arena política de un imperio que ya no era sino la pobre sombra de lo que había sido décadas atrás ${ }^{276}$. Bajo su liderazgo, los burgundios lograron ampliar su zona de dominio directo, apoderándose de territorios situados entre los Alpes y el Ródano y expandiéndose hacia el sur. Mientras tanto, Eurico siguió su expansión por la Galia: derrotó a Ecdicio, patricio enviado por Julio Nepote a defender Clermont de sus ataques, y conquistó Provenza, que devolvió más tarde al imperio a cambio de Clermont ${ }^{277}$. Pronto el emperador perdió

\footnotetext{
${ }^{270}$ Sid., Ep., 1.9 .8 (año 468) y 1.7 (año 468).

${ }^{271}$ Harries 1994, 222-223.

${ }^{272}$ Sid., Ep., 3.1 .4 (c. 472).

${ }^{273}$ Halsall 2007, 276-277; Wolfram 1990, 183.

${ }^{274}$ Chron. Gall. a. DXI, 650 (año 472).

${ }^{275}$ Halsall 2007, 278.

${ }^{276}$ Shanzer y Wood 2002, 16; Harries 1994, 226.

277 Sid., Ep., 3.3 (año 474). Sobre la plausibilidad del relato de Sidonio, quien dice que Ecdicio contaba solo con dieciocho hombres, véase Halsall 2003, 124.
} 
también el apoyo del ejército italiano y huyó a Dalmacia desde donde pretendió seguir gobernando. El imperio quedó entonces en manos de Rómulo Augústulo, hijo de Orestes, quien había sucedido a Ricimero como generalissimo. Solo Italia y Provenza constituían en este momento el territorio de occidente cuando sobrevino un nuevo golpe de Estado. Para estos años, el ejército regular había pasado a estar constituido en gran medida por federados de distinta procedencia. A mediados de 476, y probablemente en respuesta al incumplimiento de la paga por parte del gobierno de occidente, los soldados exigieron a Orestes un acuerdo similar al que se había establecido con los bárbaros en la Galia. El rechazo del pedido por parte del general dio curso a un motín que culminó con la muerte de aquel, la deposición del emperador y la proclamación como rey de Odoacro, un oficial esciro. Probablemente por esas mismas fechas las fuerzas de Eurico se apoderaban de los restos de la Galia romana. Odoacro envió entonces embajadores a la corte oriental para comunicar que ya no hacía falta un emperador en occidente. Como Rómulo Augústulo no había sido aceptado en Constantinopla, Zenón urgió a Odoacro a reconocer a Julio Nepote que aún estaba en Dalmacia. Bajo estas circunstancias, Odoacro decidió ignorar el mandamiento ${ }^{278}$.

\section{EL FIN DEL IMPERIO EN LA GALIA}

La escasa notoriedad del golpe de Estado de Odoacro (que sin embargo, no pasó inadvertido para Sidonio Apolinar ${ }^{279}$ ) no radica en la pretendida continuidad de la vida social y política en los territorios occidentales con posterioridad al año 476 , sino en que representa un momento más en el proceso de mediana duración que condujo al quiebre de las estructuras estatales antiguas. En esta breve exposición ha quedado claro que el imperio dejó de existir en diferentes fechas según las regiones.

En el centro-sur de la Galia -excepción hecha de Aquitania- la caída sobrevino entre los años 468-476, acelerada por una fuerte disidencia interna frente a un gobierno central moribundo. El ejemplo más destacado de defección fue el de Arvando, quien inmediatamente después del fracaso de la expedición al África de las fuerzas de Antemio intentó convencer a Eurico de no pactar la paz con el imperio y negociar un

\footnotetext{
${ }^{278}$ Jones 1964, 243-246; Wolfram 1990, 188-189; Heather 2006, 538-542.

${ }^{279}$ Harries 1994, v.
} 
reparto territorial de la Galia con los burgundios ${ }^{280}$. La opinión entre los terratenientes galos estaba dividida, pues otros se aferraban a la ilusión de un porvenir dentro de las estructuras imperiales, como Sidonio y su círculo ${ }^{281}$. Pero no parece probable que el apoyo a los bárbaros se diera a partir de un cálculo de costo-beneficio por parte de los poderosos locales en su conjunto, según el cual resultara conveniente vivir bajo dominación de los bárbaros ${ }^{282}$. ¿Qué ventajas suponía para la aristocracia como clase subordinarse a un rey que pretendía mantener la estructura estatal imperial, incluido el aparato fiscal? Probablemente haya que analizar los comportamientos atendiendo más a los constreñimientos inmediatos de los actores y a la configuración de las luchas entre facciones por el poder local que en perspectivas estratégicas de conjunto. En este sentido, es importante tener presente que el control de la curia entrañaba el de la gestión del impuesto al nivel de la civitas. De todos modos, la razón principal que debió de inclinar a parte de las elites galas a desprenderse del gobierno imperial fue la indefensión frente al avance territorial de los poderes externos (visigodos y burgundios sobre todo). En esas circunstancias, la decisión más atinada para una facción aristocrática podía ser la de facilitar la conquista para ganarse el favor de quien sin dudas sería el próximo soberano. Esta fue la situación que empujó a parte de los ciudadanos de Clermont a apoyar la conquista de Eurico, mientras Sidonio y los suyos se mostraban leales en apariencia, pues es probable que con el agravamiento del asedio visigodo estos últimos comenzasen a negociar una rendición a los burgundios ${ }^{283}$. Otros, finalmente, abandonaron la arena pública para refugiarse en sus propiedades rurales ${ }^{284}$.

El imperio cayó entonces como consecuencia de la incapacidad para hacer frente a un peligro externo que visto en retrospectiva puede parecer menos dañino de lo que terminó siendo. El imperio no fue simplemente asesinado ${ }^{285}$. El número total de invasores armados rondó los 110 a 120 mil efectivos, un número bastante inferior al medio millón que según un cálculo conservador tenía el ejército romano para el siglo

\footnotetext{
280 Sid., Ep., 1.7.5. También tuvo resonancia el caso de Seronato, subprefecto de la Galia que fue ejecutado al ser encontrado culpable en 475 de haber facilitado la entrega de territorios galos a Eurico (Sid., Ep., 7.7.2, año 474/475).

${ }^{281}$ Harries 1994, 226-227; Heather 2006, 529-530.

282 Como sugiere Alföldy $(1987,287)$.

${ }^{283}$ Harries 1994, 229-236; Sid., Ep., 3.3 (año 474).

${ }^{284}$ Sid., Ep., 1.6 (año 467) y 7.15 (c. 470). De todos modos parece que la residencia urbana continuó siendo una característica del sur galo (Wickham 2005, 667-668).

${ }^{285}$ Piganiol 1947, 422.
} 
$\mathrm{IV}^{286}$. A esto debería añadirse una superioridad militar leve, pero cierta, de los ejércitos romanos sobre los germanos ${ }^{287}$. Sin embargo, los números resultan engañosos en la medida en que buena parte de esos efectivos debían destinarse a la protección de otros frentes potencialmente peligrosos, de modo que al comenzar las invasiones el ejército de campaña de occidente no contaba quizás con más que 80 mil soldados. La respuesta a porqué el gobierno central no respondió a esta desventaja numérica fortaleciendo su aparato militar es la que desnuda las limitaciones internas del sistema. Sencillamente fue incapaz de incrementar los ingresos fiscales por encima de lo que lo había hecho desde fines del siglo III, ya sea porque no supo o no quiso presionar más a las aristocracias cuando aún controlaba buena parte del territorio occidental o porque cuando se vio obligado a hacerlo la base contribuyente ya se había reducido considerablemente tanto por el avance de los enemigos como por las devastaciones que provocaban las guerras ${ }^{288}$.

Por otro lado, la misma reflexión que adoptásemos para pensar la defección o lealtad de las aristocracias romanas frente al avance de los bárbaros sirve para pensar las acciones de los emperadores y generalissimos occidentales del siglo V. Estos personajes se vieron con frecuencia obligados a responder a problemas inmediatos que surgían desde distintos frentes -no solo externos sino también internos- con los recursos disponibles coyunturalmente. En este punto, resulta difícil sostener tanto que el asentamiento de los germanos fuera un proyecto que se le fue de las manos al gobierno romano (Goffart), como que el imperio "se suicidara accidentalmente" como producto de un cúmulo de decisiones erróneas adoptadas por personajes que no pretendían que tal cosa sucediese (Halsall) ${ }^{289}$.

Es necesario concluir este capítulo con una reflexión en torno a la situación económica de la región del centro y sur de la Galia hacia los años de la caída final del imperio $^{290}$. Como tendremos oportunidad de ver más adelante, la arqueología demuestra evidencias contundentes de retracción de la cultura material en la región. Las guerras frecuentes habían contribuido mucho a dicho empobrecimiento y continuarían

\footnotetext{
${ }^{286}$ Lee $(1998,220)$ estima entre 500 y 700 mil el número de efectivos romanos. Heather $(2006,562)$ excluye de la cuenta de los invasores a los anglosajones que ocuparon Britania, pues estos no fueron la causa de la crisis del orden romano en dicha provincia.

${ }^{287}$ Ward-Perkins 2005, 34-38.

${ }^{288}$ Ward-Perkins 2005, 40-43; Heather 2006, 563-564.

${ }^{289}$ Halsall 2007, 282-283.

${ }^{290}$ Estas cuestiones serán analizadas más ampliamente en los capítulos 4-6.
} 
haciéndolo. En el cierre del periodo aquí analizado, Sidonio escribía a Paciencio de Lyon que

cuando las incursiones de los godos terminaron, y todos los cultivos fueron quemados por el fuego, tú distribuiste de tus propios recursos el grano entre los desposeídos a través de toda la tierra arruinada de la Galia, aunque hubiese sido suficiente alivio para nuestra población hambrienta que el grano les llegase no como un regalo, sino por los canales usuales del comercio ${ }^{291}$.

El mercado acusaba para entonces una ralentización en el flujo de los intercambios como consecuencia de la merma en la capacidad consumidora de las aristocracias y del Estado. La relativa continuidad en las actividades comerciales de un puerto como el de Marsella no contradice el panorama global.

La razón principal que se hallaba detrás de la caída de la producción y el empobrecimiento de las aristocracias era la progresiva incapacidad de estas últimas para mantener los lazos de dominación tradicionales. El fenómeno, que comenzaba a manifestarse con fuerza al promediar el siglo $\mathrm{V}$, era una consecuencia directa de la crisis político-militar de la región. Aunque solapadamente, se percibe en la documentación del periodo la existencia de servi y coloni que huían o se rehusaban a ser explotados. No parecen meras exageraciones las observaciones de Sidonio Apolinar en torno a la inseguridad de los tiempos que le había tocado vivir ${ }^{292}$. Los peligros en los caminos entorpecían la fluidez del intercambio epistolar ${ }^{293}$. La inestabilidad política general constituyó el medio más adecuado para la germinación de este tipo de rebeldía, así como la que encarnaron los contribuyentes frente a los restos del aparato físcal.

\footnotetext{
291 Sid., Ep., 6.12 .5 (año 474): "post Gothicam depopulationem, post segetes incendio absumptas peculiari sumptu inopiae communi per desolatas Gallias gratuita frumenta misisti, cum tabescentibus fame populis nimium contulisses, si commercio fuisset species ista, non muneri". ${ }^{292}$ Sid., Ep., 6.4 (c. 472) y 8.11 (c. 480).

293 Sid., Ep., 7.10 (año 474), 7.11 (año 473), 9.3 (c. 477) y 9.5 (c. 477). Ello no quiere decir que el intercambio epistolar no siguiera siendo posible (Ep., 9.4, año 473).
} 
3

\section{LA GALIA ROMANO-GERMÁNICA \\ HASTA c. 550}

Este capítulo repasa la historia político-militar de la Galia entre aproximadamente la caída del imperio romano y los años centrales del siglo VI. No obstante, el análisis se inicia con un apartado dedicado a los asentamientos de los visigodos y los burgundios, necesario para comprender el desenvolvimiento posterior de los dos primeros Estados germánicos de la región. El objetivo principal del capítulo será poner de relieve el carácter endémico de la guerra en el periodo analizado y ponderar sus consecuencias sociales. Las distintas entidades políticas del periodo estuvieron casi permanentemente en conflicto entre ellas, de modo que los procesos ocurridos en unas tuvieron efectos directos sobre las otras. En tal sentido, pese a que esta tesis estudia particularmente la región del centro-sudeste, será preciso examinar con similar detenimiento la evolución de los acontecimientos políticos y militares en toda la Galia.

\section{EL ASENTAMIENTO DE VISIGODOS Y BURGUNDIOS}

El carácter de los asentamientos germánicos ha sido un tema muy debatido historiográficamente. Conviene reseñar la discusión con cierto detalle. 
En 1844, Theodor Gaupp propuso que los bárbaros habían obtenido tierras del gobierno imperial según los criterios aplicados tradicionalmente al alojamiento de soldados. La legislación romana obligaba a los ciudadanos a ceder un tercio de sus propiedades para el acuartelamiento de un hospes si eventualmente lo requerían las autoridades militares ${ }^{294}$. Gaupp encontró similitudes entre estas normas y otras establecidas por los visigodos y los burgundios sobre tercios de tierras que debían ser divididos entre bárbaros y romanos, por un lado, y con documentación de la Italia postromana que también hacía referencia a ostrogodos que poseían tertiae (tercios) y sortes (lotes o partes), por otro. Si bien en un principio estos hospites germanos no habrían tenido la propiedad de las tierras en las que se asentaron, el derecho de ocupación habría derivado en dominium con el paso del tiempo. Sabemos que los soldados acuartelados en las tierras de los romanos cometían abusos que la ley intentaba castigar ${ }^{295}$.

Una de las críticas que recibió la tesis de este autor se centró en lo difícil que resultaba explicar desde su perspectiva la casi ausencia de documentación que testimoniase quejas por parte de una población autóctona que teóricamente se había visto obligada a desprenderse de buenas a primeras de las tierras que le pertenecían. Historiadores posteriores como Hans Delbrük y Ferdinand Lot creyeron resolver el problema argumentando que la cesión de una pequeña parte de las propiedades territoriales había sido suficiente para asentar a los bárbaros, habida cuenta del reducido tamaño de los ejércitos federados en relación a la extensión de las regiones en las que se había decretado su alojamiento ${ }^{296}$.

El debate experimentó un viraje significativo en 1980 con la publicación de Barbarians and romans: the techniques of accomodation. Allí, Walter Goffart indicó que los asentamientos de los germanos no se realizaron en modo alguno aplicando el sistema de alojamiento de los soldados ${ }^{297}$, el cual no establecía ninguna disposición con respecto a la producción o a los ingresos de las tierras sobre las que debían instalarse los

\footnotetext{
${ }^{294}$ C. Th., 7.8 .5 (año 393).

${ }^{295}$ C. Th., 7.8.10.2 (año 413). Véase también C. Th., 7.9 (años 340-416), todo un título dedicado a proteger de exacciones ilegales de madera, aceite, etc. a quienes ofrecían alojamiento.

${ }^{296}$ Para una reseña de la obra de Gaupp y de los debates originados hasta la publicación de la tesis de Goffart, véase Halsall 2007, 422-447. Puede encontrarse un ejemplo de interpretación tradicional en Jones 1964, 201-202 y 248-253.

297 "Hospitalitas" no era un término técnico, sino uno entre muchos utilizados en las leyes que versaban sobre el sistema regulado de acuartelamiento (Goffart 1980, 41-43).
} 
huéspedes, ni sobre la alimentación de los $\operatorname{mismos}^{298}$, pues se suponía que el mantenimiento de los soldados debía de ser suministrado por la ciudadanía en su conjunto a través de los impuestos ${ }^{299}$. Según este historiador, el único vínculo entre el principio de regulación del acuartelamiento y las medidas adoptadas por los romanos en torno al asentamiento de los bárbaros parece haber sido el curioso hecho de que una de las leyes compiladas en el Código Teodosiano concernientes a la hospitalitas estableciera, para goce de los alojados, fracciones de la casa del huésped en partes similares a las que se encuentran en leyes de los visigodos y los burgundios ${ }^{300}$.

En su opinión, el procedimiento de asentamiento de visigodos y burgundios en la Galia (y el de ostrogodos y lombardos en Italia) habría consistido en una delegatio mediante la cual el Estado transfirió su deuda con los soldados federados -al fin de cuentas, asalariados públicos- a manos de los contribuyentes, deudores del fisco. Vale decir que se cedió a los soldados de los ejércitos bárbaros el derecho a cobrar personalmente los impuestos que anteriormente se pagaban a las autoridades romanas $^{301}$. Esto no significa que para Goffart se siguiese el mismo procedimiento en todos los casos en que los bárbaros se instalaron en territorio imperial. El acuerdo de asentamiento de los alanos en la Galia parece haber consistido en la expropiación de los locales ${ }^{302}$. Por otra parte, vándalos y suevos conquistaron por las armas las regiones en las que se establecieron.

El expediente seguido en los casos visigodo, burgundio, ostrogodo y lombardo no habría comportado perjuicio alguno para los ciudadanos en opinión de Goffart, pues estos habrían retenido la propiedad por la cual continuaban pagando los mismos impuestos de siempre. Se dilucidaba así la razón de la ausencia de quejas de los

\footnotetext{
${ }^{298}$ Como se deduce de C. Th., 7.8.10.2 ("Solam sane hospitalitatem sub hac observatione concedimus, ut nihil ab hospite, quod vel hominum vel animalium pastui necessarium creditur, postuletur omniumque sit adceleratum iter atque continuum nec ulli liceat residere, ne diuturnitas conmanentium ulla ex parte praedium vexet").

${ }^{299}$ C. Th., 7.9 .4 (año 416) prohibía a los hospedados exigir aceite o madera, pues los contribuyentes solo estaban sujetos al pago del impuesto anual ("Nullus eorum, qui per quaslibet aedes habitaculi causa recepti fuerint, vel oleum et ligna flagitare contendat, nam et sic militibus nostrae sufficient largitates et collatoribus annua tantummodo semper imminebit indictio").

${ }^{300}$ C. Th., 7.8.5.

${ }^{301}$ Goffart abre el análisis específico de los casos a partir del ostrogodo (capítulo 3) por ser el único para el cual se cuenta con documentación idónea contemporánea al asentamiento (las Variae de Casiodoro y las Epistulae de Enodio). El libro se cierra con el estudio del caso lombardo (capítulo 7). Los planteos giran en torno a los lineamientos generales que hemos trazado en el cuerpo del trabajo. Para una crítica puntual al caso ostrogodo, véase Barnish 1986.

${ }^{302}$ Chron. Gall. a. CCCCLII, 127 (año 441/442): “Alani, quibus terrae Galliae ulterioris cum incolis divi dendae a patricio Aetio traditae fuerant, resistentes armis subigunt et expulsis dominis terrae possessionem vi adi piscuntur". Goffart 1980, 111.
} 
romanos con respecto a las asignaciones. Por otro lado, la conformidad con este sistema por parte de los soldados de los ejércitos federados habría residido fundamentalmente en el hecho de que los libraba de los problemas relacionados con los intermediarios tradicionales del sistema fiscal ${ }^{303}$.

Nos centraremos a continuación en la discusión suscitada a partir de sus planteos en torno a los casos visigodo y burgundio. Las adhesiones y rechazos han estado a la orden del día en un tema particularmente propicio para la construcción de modelos debido no solo a la escasez de documentación apropiada, sino también al carácter muchas veces tardío de esos testimonios. Difícilmente el debate logre zanjarse definitivamente en estas circunstancias.

\section{El caso visigodo}

La documentación con que contamos para analizar el caso visigodo es una serie de muy escuetas entradas en las crónicas y algunas leyes posteriores. Lo medular en cuanto a la información legislativa se reduce a las constituciones 276 y 277 del Código de Eurico, que habría que datar en torno a 475. El texto (277.1-2) establecía (1) que las sortes de los godos y la tertia de los romanos que no habían sido recuperadas dentro de los cincuenta años no podían ser reclamadas y (2) que lo mismo debía de aplicarse respecto de los fugitivos: no podían ser llamados a servicio aquellos que no habían sido encontrados dentro de los cincuenta años. Para Goffart, a pesar de que en esta prescripción se esté hablando claramente de tierras, existe la posibilidad de que originalmente las asignaciones de sortes y tertia fueran derechos fiscales. En su opinión, el asentamiento de 419 habría consistido entonces en la transmisión del derecho a cobrar impuestos en la región ${ }^{304}$. Esta fue la "tierra" cedida a los godos, de la cual, con la evolución de los años, provendrían las sortes y la tertia que se mencionan en las citadas constituciones. Probablemente en un principio se estableciera una división en tercios, a partir de la cual uno quedara para el rey -y quizás los nobles-y los otros dos para los soldados (mediante asignaciones de carácter individual). En consecuencia,

\footnotetext{
${ }^{303}$ Goffart 1980, 40-54.

${ }^{304}$ Andreas Schwarcz $(2001,15-18)$ ha rechazado recientemente la datación tradicional de 418, basada en la edición que Theodor Mommsen hizo de la crónica de Hidacio, para proponer la de 419, haciendo coincidir al cronista hispano con Próspero de Aquitania. La fecha de 415 establecida en Chron. Gall. a. CCCCLII, 73, es unánimemente rechazada. Las dudas sobre la edición de Mommsen ya habían emergido en Wood 1992, 15.
} 
ningún romano habría perdido inicialmente la propiedad de la tierra, pero mientras que algunos habrían quedado supeditados fiscalmente al rey, otros habrían debido pagar impuestos a soldados visigodos en particular ${ }^{305}$.

La falta de quejas por parte de la aristocracia aquitana a posteriori del acuerdo es utilizada por Goffart como argumento para reforzar su teoría. Pero como es bien sabido, no debe confundirse la ausencia de evidencia con la evidencia de ausencia. Además, habría que resaltar que para 419 la aristocracia romana de Aquitania Secunda tenía pocas razones para oponerse al asentamiento visigodo en sus tierras. La presencia militar de los federados seguramente llevase tranquilidad, sobre todo frente a la amenaza de los vándalos, que fueron derrotados por los visigodos en $422^{306}$. Es probable incluso que el Consejo de las Siete Provincias, reunido por primera vez en abril de 418 , diera el beneplácito para el acuerdo ${ }^{307}$. Finalmente, las crónicas de Hidacio y Próspero no parecen avalar la teoría de Goffart ${ }^{308}$.

Por otro lado, puede que el paso de los bárbaros por Aquitania entre 407 y 414 dejase como secuela tierras abandonadas como consecuencia sobre todo de la migración de aristócratas ${ }^{309}$. Asentar a los visigodos en esas tierras o en otras del fisco habría sido entonces una solución razonable a los problemas vigentes: los bárbaros obtenían una fuente sustentable de alimento, mientras que los romanos lograban sellar un acuerdo militar evitando tener que lidiar a futuro con un ejército merodeador. Esto no excluye ni que se realizaran ciertas expropiaciones, ni que los reyes terminaran financiándose eventualmente mediante la apropiación del aparato fiscal romano ${ }^{310}$. Las primeras bien podrían haber constituido castigos puntuales a personajes que habían mostrado deslealtad hacia el imperio en los pasados años agitados. De hecho no se descarta que dentro de los móviles del imperio para asentar a los visigodos estuviese la voluntad de controlar militarmente una región peligrosa por su capacidad para erigir usurpadores,

\footnotetext{
${ }^{305}$ Goffart 1980, 118-125.

${ }^{306}$ Burns 1992, 57.

${ }^{307}$ Schwarcz 2001, 18.

308 Prosp., Chron., 1271: "Constantius patricius pacem firmat cum Wallia data ei ad inhabitandum secunda Aquitanica et quibusdam civitatibus confinium provinciarum"; Hyd., Chron., 69: "Gothi intermisso certamine quod agebant per Constantium ad Gallias revo cati sedes in Aquitanica a Tolouse usque ad Oceanum acceperunt. Gothi sedentes in Aquitania Tholosa sibi sedem elegunt: a mare Terrenum et fluvio Rodano per Ligerem fluvium usque Ocianum possident"'.

${ }^{309}$ Mathisen 1993, 60-64.

${ }^{310}$ Nixon 1992, 68-75. Harries $(1994,65)$ también sugiere que se ocuparon tierras abandonadas.
} 
aparte de su uso potencial como fuerza de represión contra otros bárbaros y contra las bagaudas $^{311}$.

Cualquiera haya sido la relación inicial entre los aristócratas aquitanos y los visigodos, los primeros fueron encontrando inserción en la burocracia civil y en el ejército $^{312}$. Es probable que desde estas esferas presionasen al rey para ser tratados del mismo modo que sus pares germanos de cara al fisco, es decir, con inmunidad. Trataremos con mayor profundidad el problema de la reproducción del aparto impositivo en los Estados post-romanos en el próximo capítulo. Importa señalar ahora que es probable que esta situación general tendiera a restituir una práctica que había sido la tradicional en los ejércitos germanos: financiar la milicia a través de la guerra ${ }^{313}$. De tal modo, la política de saqueos emprendida con posterioridad al asentamiento se entendería como algo buscado no solo por los componentes más directamente vinculados al aparato estatal del reino, sino también por obispos o miembros de las aristocracias locales interesados en que se encontrara financiamiento fuera de la región.

\section{El caso burgundio}

En el contexto de desconcierto producido por las invasiones de 406, los burgundios consiguieron establecerse en territorio romano cerca de la ciudad de Maguncia (Mainz), probablemente en 411. Desde allí sirvieron de apoyo al régimen del usurpador Jovino, aparentemente en alianza con alanos que también se habían asentado en la región. El acuerdo les granjeó la obtención en 413 de tierras sobre el territorio de Worms a cambio de servicio militar como tropas federadas ${ }^{314}$.

Poco se sabe de las dos décadas siguientes con respecto a estos burgundios, pero el hecho de que haya noticias de represión militar a incursiones suyas en territorio belga indicaría que en los años inmediatos se produjo una consolidación de su poder en esa

\footnotetext{
${ }^{311}$ Kulikowski 2001, 32-34; Ward-Perkins 2005, 54.

${ }^{312}$ Mathisen 1993, 126-128.

${ }^{313}$ Hablando de los germanos, dice Tácito que "[l]a fuente de su generosidad puede subsistir gracias a las guerras y [los] saqueos. No se les puede convencer para que aren la tierra o esperen la cosecha tan fácilmente como para que provoquen al enemigo o se expongan a las heridas: es más, les parece de apocados y cobardes adquirir con sudor lo que puede lograrse con sangre" (Ger., 14.3-4: "exigunt enim a principis sui liberalitate ilium bellatorem equum, illam cruentam victricemque frameam; nam epulae et quamquam incompti, largi tamen apparatus pro stipendio cedunt. Materia munificentiae per bella et raptus. Nee arare terram aut exspectare annum tam facile persuaseris quam vocare hostem et vulnera mereri. Pigrum quin immo et iners videtur sudore adquirere quod possis sanguine parare").

${ }^{314}$ Favrod 2002, 24-25
} 
base renana. En cualquier caso, esto les serviría de muy poco tras su enfrentamiento en 436 o 437 con los hunos, aliados circunstanciales de Aecio. Las fuentes coinciden en señalar que la derrota fue catastrófica para los burgundios ${ }^{315}$, pero aun así no se rompió la transmisión del poder dentro de la dinastía gobernante ${ }^{316}$.

Los supervivientes fueron instalados en Sapaudia, el amplio territorio que rodeaba a la ciudad de Ginebra, en 442 o 443, probablemente por orden de Aecio $^{317}$. Seis años mediaron entre la batalla y el asentamiento, un intervalo que resulta significativo a la hora de evaluar los términos del acuerdo. En ese tiempo los germanos bien pudieron haberse recuperado numéricamente gracias a la recepción de migrantes $^{318}$, pudiendo así ejercer una mayor presión sobre las autoridades romanas. Por otro lado, el imperio necesitaba de un ejército aliado que contuviera la frontera mientras se preocupaba por la urgente tarea de recuperar el África, perdida a manos de los vándalos en 439 .

La discusión en torno al carácter del tratado reproduce, mutatis mutandi, los términos planteados en el debate sobre el acuerdo entre romanos y visigodos de 419 . Goffart se apoya en este caso en la interpretación de una disposición contenida en el Liber Constitutionem sancionada por el rey Gundobado entre 501 y 516, es decir como mínimo luego de más de medio siglo de llevado a cabo el asentamiento inicial ${ }^{319}$. Dicha norma establecía medidas coercitivas hacia quienes hubieren transgredido o transgredieran en el futuro una disposición previa que prohibía la apropiación de dos tercios de terrae y uno de mancipia por parte de burgundios a quienes por gracia de los reyes ya habían sido entregadas otras tierras y otros esclavos. La pena estipulada era la devolución de todo lo apropiado ilegalmente. También se establecían sanciones sobre quienes no compartieran en partes iguales con los possessores romanos las tierras $\operatorname{roturadas}^{320}$.

\footnotetext{
${ }^{315}$ Prosp., Chron., 1322; Chron. Gall. a. CCCCLII, 118; Hyd., Chron., 110.

${ }^{316}$ Gundioc sucedió en 437 a su padre Gudahario (PLRE, 2, 523-524 y 526).

${ }^{317}$ No en Saboya, como se sostiene a menudo (Favrod 2002, 45-47).

318 Este es un argumento especulativo, pero se fundamenta en la evidencia de procesos migratorios posteriores en el reino (véase infra).

${ }^{319}$ Puede establecerse una cronología aproximada de la legislación burgundia. Los títulos 2-41 del Liber Constitutionem contendrían disposiciones emitidas entre los años 483 y 501; los títulos 42-88, normas de los años 501-17 y, finalmente, los títulos 89-105 y las Constitutiones Extravagantes datarían del reinado de Godomar o de los años posteriores a la conquista de los francos, aunque algunas leyes de este último grupo podrían tener una redacción anterior (como Const. Ext., 19 y 20) (Fischer Drew 1972, 6-8).

${ }_{320}$ Lib. Const., 54.1 .2 ("[1] Licet eodem tempore, quo populus noster mancipiorum tertiam et duas terrarum partes accepit, eiusmodi a nobis fuerit emissa praeceptio, ut quicumque agrumcum mancipiis seu parentum nostrorum sive nostra largitate perceperat, nec mancipiorum tertiam nec duas terrarum
} 
Para Goffart sería posible reconstruir tres procesos históricos a través del contenido de la ley; en orden cronológico regresivo: a) los abusos contemporáneos, de los que trataba la disposición, b) la ordenanza sobre esclavos y tierras, que probablemente databa de c. 480 en adelante, y que con toda seguridad modificaba asignaciones realizadas previamente, y c) la época en la que se habían hecho los repartos originales ${ }^{321}$. En su opinión, las terrae de las que habla el código serían tierras arables sujetas a gravámenes públicos, mientras que los mancipia serían cultivadores coloni o esclavos- que tributaban. El acuerdo original habría consistido en que los burgundios recibieran a título individual derechos fiscales sobre uno o varios contribuyentes para sí, mientras que al rey le habrían correspondido terrae con mancipia, vale decir, derecho sobre las tierras de los grandes terratenientes y los dependientes a ellas adscriptos ${ }^{322}$.

Chris Wickham ha planteado que si bien la tesis general de Goffart sobre el asentamiento de los germanos no parece descabellada, el hecho es que no está avalada por ningún documento ${ }^{323}$. Wolf Liebeschuetz, por su parte, ha criticado la resignificación que Goffart propone de términos como "terra" y "sors" para el caso burgundio, poniendo el acento en el análisis de otras disposiciones legales que no resisten una interpretación diferente a la tradicional ${ }^{324}$. El propio Goffart admite que en ninguna de las leyes burgundias las asignaciones se conectan de manera evidente con los impuestos ${ }^{325}$. A pesar de ello, su interpretación ha recibido el apoyo de Justin Favrod, quien agrega como dato a tener en cuenta el hecho de que las prospecciones arqueológicas de la primera época del reino arrojan como resultado una concentración del hábitat de los germanos en las cercanías de Ginebra, en lugar de una dispersión por

\footnotetext{
partes ex eo loco, in quo ei hospitalitas fuerat delegata requirere, tamen quia complures comperimus, inmemores periculi sui, ea quae praecepta fuerant excessisse, necesse est, ut praesens auctoritas, ad instar mansurae legis emissa, et praesumptores coerceat et hucusque contemptis remedium debitae securitatis adtribuat. Iubemus igitur: ut quidquid ab his, qui agris et mancipiis nostra munificentia potiuntur, de hospitum suorum terris contra interdictum publicum praesumpsisse docentur, sine dilatione restituant. [2] De exartis quoque novam nunc et superfluam faramannorum conpetitionem et calumniam possessorum gravamine et inquietudine hac lege praecipimus submoveri: ut sicut de silvis, ita et de exartis, sive anteacto sive in praesenti tempore factis, habeant cum Burgundionibus rationem; quoniam, sicut iam dudum statutum est, medietatem silvarum ad Romanos generaliter praecipimus pertinere; simili de curte et pomariis circa faramannos conditione servata, id est: ut medietatem Romani estiment praesumendam").

${ }^{321}$ Goffart 1980, 130.

${ }^{322}$ Goffart 1980, 137-140.

${ }^{323}$ Wickham 2005, 84-86.

${ }^{324}$ Liebeschuetz 1997, 146.

${ }^{325}$ Goffart 1980, 132.
} 
toda Sapaudia, algo que cabría esperar si se hubiera tratado de un reparto de tierras ${ }^{326}$. Sin embargo, la arqueología no puede demostrar que se pactase la cesión de derechos fiscales. En todo caso solo puede probar que buena parte de los burgundios vivió agrupada en ciertas zonas, pero esto sería compatible con la existencia de expropiaciones concentradas geográficamente. También podría haber ocurrido que se distribuyesen tierras de distintas zonas pero que los germanos se convirtiesen en propietarios absentistas. Puesto que se trató inicialmente del asentamiento de un ejército, no es ilógico suponer que se privilegiase un hábitat concentrado.

También se ha sugerido que una entrada en la crónica de Fredegario, erróneamente fechada en 373, respaldaría la teoría del reparto de impuestos. El texto indica que los romanos habían invitado a los burgundios a la Galia para así poder dejar de pagar tributos ${ }^{327}$. Pero la fuente es muy tardía y su contenido admite una interpretación distinta. Los romanos en cuestión bien pudieron haber sido algunos privilegiados que se beneficiaron con la reducción o eliminación de sus impuestos a cambio de la cesión de tierras. Por otro lado, según Goffart el acuerdo de instalación de los bárbaros no implicaba que los propietarios romanos quedasen exentos de cargas públicas.

Mientras que la tesis del reparto de asignaciones fiscales genera dudas, la entrega de tierras parece estar probada. Cuando la Crónica gala del año 452 informa que "Sapaudia fue dada a los supervivientes burgundios para ser dividida con sus habitantes", es difícil no interpretar esto como un reparto de tierras ${ }^{328}$. El mismo argumento sobre la asignación de propiedades abandonadas que se hiciera para el caso visigodo puede ser planteado también para este. La crónica de Mario de Avenches menciona un reparto posterior de tierras en el que parte de la aristocracia local de Lyon cedió propiedades para ganar apoyo contra el gobierno imperial ${ }^{329}$. Finalmente, en la Vita Lupicini hay una clara referencia al peligro de perder tierras a manos de un "novus

\footnotetext{
${ }^{326}$ Favrod 2002, 48-50.

${ }^{327}$ Fred., Chron., 2.46 (Burgundionum octoaginta fere milia, quod numquam antea nec nominabantur, ad Renum discenderunt et ubi castra posuerunt, quasi burgo vocitaverunt; ob hoc nomen acciperunt Burgundiones. Ibique nihil aliud praesumebant, nisi quantum praecium ementis a Germanis, eorum stipendia accipiebant. Et cum ibidem duobus annis resedissent, per legatis invitati a Romanis vel Gallis, qui Lugdunensium provinciam et Gallea comata, Gallea domata et Gallea Cesalpinae manebant, ut tributa rei publice potuissent rennuere, ibi cum uxoris et liberes visi sunt consedisse. Valentinianus subito a sanguine eruptione, quod Greci eproploxia vocatur, Brivione moritur"); Wood 2003, 258-259.

${ }^{328}$ Chron. Gall. a. CCCCLII, 128: "Sapaudia Burgundionum reliquiis datur cum indigenis dividenda".

${ }^{329}$ Mar. Avent., Chron., a. 456: "Eo anno Burgundiones partem Galliae occupaverunt terrasque cum Gallis senatoribus diviserunt". De todas maneras, a juzgar por el testimonio de Sidonio Apolinar, también se produjeron acantonamientos en el sentido tradicional en ese periodo (Carm., 12, año 457 o 461).
} 
hospes" 330 . En consecuencia, es importante destacar con Ian Wood que cualquiera haya sido el carácter de los acuerdos iniciales, existieron asignaciones posteriores que parecen haber consistido a todas luces en adjudicaciones de tierras y esclavos ${ }^{331}$.

Conviene cerrar este apartado con una reflexión similar a la planteada para pensar la relación entre la aristocracia aquitana y los visigodos con posterioridad al asentamiento de 419. Si bien los burgundios dieron muestras de un mayor compromiso en el cumplimiento del foedus con el gobierno imperial que aquellos germanos -al punto de gozar sus reyes de títulos oficiales, como veremos-, es posible que la inserción de las aristocracias galo-romanas de la región en la maquinaria cívica y militar del reino tuviese con el tiempo las mismas consecuencias que hemos planteado para el caso aquitano.

\section{Balance}

Matthew Innes ha realizado recientemente una reconsideración sobre la naturaleza de la instalación de los bárbaros que tuvo lugar entre los siglos $\mathrm{V}$ y VI en occidente que nos parece oportuno retomar a modo de balance de lo expuesto hasta aquí. El autor propone que en las primeras etapas de los asentamientos, particularmente en las regiones militarmente desprotegidas de la Galia, se produjo una transferencia sistemática de los frutos de la tierra en favor de los invasores. Los comentarios contemporáneos son escasos, pero apuntan unánimemente a un proceso de negociación atravesado por la coerción o la experiencia reciente de la violencia. Por otro lado, Innes se aleja de las posturas que insisten en percibir la instalación como un hecho puntual producto de la articulación de un principio administrativo para centrar la problemática en el conflicto prolongado entre bárbaros y provinciales. Ambas cuestiones se ven reflejadas en una carta escrita c. 470 por Sidonio, en la que el autor informa a su amigo Ecdicio de la dura situación que estaba atravesando la región de Auvernia; puntualmente, Seronato (probablemente el gobernador de Aquitanica I en ese momento) estaba "llenando los bosques de fugitivos y las granjas de ocupantes bárbaros"332.

\footnotetext{
${ }^{330}$ V. Pat. Iur., 94: "Tandem resipisce paulisper et vide, utrum rura ac iugera tua novus hospes inexpectata iuris dispectione sibi non vin dicet hac praesumat" (Lupicinio se dirige en este pasaje al rey Chilperico I). Véase la interpretación de Wolfram 1997, 182.

${ }^{331}$ Wood 2003, 259; Wolfram 1997, 182-183.

332 Sid., Ep., 2.1: "Totum quod concupiscit quasi comparat nec dat pretia contemnens nec accipit instrumenta desperans; in concilio iubet in consilio tacet, in ecclesia iocatur in convivio praedicat, in
} 
Según Innes, durante la segunda y la tercera generaciones posteriores a los asentamientos originales esas transferencias de rentas y de producto hechas de facto dieron lugar a litigios, en la medida en que los terratenientes romanos intentaron reclamar la propiedad de las tierras cuyo título tenían pero que habían albergado a los bárbaros o incluso exigir derechos sobre tierras desiertas o bosques roturados por los migrantes. Estos conflictos originaron disposiciones legales preservadas en los instrumentos administrativos y códigos legales de los reinos bárbaros. Para el caso burgundio, el autor retoma la disposición del Liber Constitutionem referida anteriormente (54, aunque la ubica en torno al año 500 y no entre 501-516 como Goffart). En su opinión Gundobado estaría reconociendo allí que los miembros de su "pueblo" (populus noster) habían recibido hospitalidad en regiones específicas (loci). Sin embargo, algunos en particular habían sido posteriormente beneficiados con tierras y esclavos por él mismo y sus antecesores. Ahora bien, del contenido de la ley se desprende que previamente el propio Gundobado había decretado que únicamente aquellos que no hubiesen recibido esos obsequios podían reclamar un tercio de los esclavos y dos tercios de la tierra del lugar en que la hospitalidad se les había $\operatorname{asignado}^{333}$.

Para Innes, la creciente expectativa de las bandas de guerreros que en el curso del siglo $\mathrm{V}$ reemplazaron al ejército romano, culminó en la transferencia sistemática de tierras. Los reyes bárbaros se vieron obligados a reconocer el hecho social y político de que sus ejércitos adquirieron tierra de los provinciales de una forma u otra. No tenían otra alternativa que intentar controlar y estructurar el proceso, a través de las leyes. De este modo, y como evidencia el caso anteriormente referido, se daba legitimidad a ciertas transferencias, mientras que se habría la posibilidad de que otras fueran ilegales. Las leyes fueron el producto de la relación de fuerzas entre una aristocracia romana en retroceso que buscaba restablecer el control sobre sus tierras y los bárbaros que buscaban la propiedad absoluta sobre las mismas. Donde la relación de fuerzas estuvo demasiado desbalanceada en favor de los guerreros bárbaros, como en el caso vándalo o lombardo, la transferencia pudo hacerse por la fuerza ${ }^{334}$.

cubiculo damnat in quaestione dormitat; implet cotidie silvas fugientibus villas hostibus altaria reis carceres clericis; exsultans Gothis insultansque Romanis, inludens praefectis conludensque numerariis, leges Theodosianas calcans Theudoricianasque proponens veteres culpas, nova tributa perquirit".

${ }^{333}$ Lib. Const., 54.1.

${ }^{334}$ Innes 2006. 
Lo que parece claro, en cualquier caso, es que el proceso de asentamiento bárbaro implicó finalmente la transferencia de la propiedad efectiva de buena parte de las tierras anteriormente controladas por la aristocracia a manos de los soldados bárbaros. Esa transferencia fue el resultado de un conflicto relativamente prolongado. A continuación atenderemos a la historia político-militar de los reinos visigodo y burgundio en el periodo posterior a la caída del gobierno imperial.

\section{EL REINO VISIGODO}

En el año 466 Eurico asumió el trono visigodo tras la muerte de su padre Teodorico. A pesar de que estaba vigente el foedus con el imperio, el territorio ocupado por el reino era mucho más extenso que el cedido inicialmente por Roma en el año 419. Como hemos visto en el capítulo anterior, la relación tuvo vaivenes que fueron aprovechados por los visigodos para ir extendiendo lentamente su radio de dominio, particularmente sobre la península ibérica. No obstante, el acuerdo se renovó periódicamente durante el transcurso de esos años. Eurico, en cambio, adoptó una política decididamente expansionista.

Entre su asunción y el año 477 el rey no solo amplió el control territorial de Hispania con la anexión de Tarraconense, sino que también pasó a dominar, grosso modo, Auvernia, Septimania, Provenza y la región de Tours. Pero durante los años siguientes se dedicó más bien a consolidar las conquistas realizadas y el dominio político del reino. Producto de ello fue, por ejemplo, la sanción del primer código legal emitido por un Estado germánico ${ }^{335}$.

Tras su muerte en 484 el cargo fue heredado por su hijo Alarico II. La estabilidad del reino comenzó a ser puesta en jaque en la década siguiente. Entre los años 496 y 498 los francos atacaron los territorios visigodos situados al sur del Loira, logrando ocupar Saintes y Burdeos. Hubo una efímera recuperación: en 500 los visigodos lograron recomponer su poderío al punto de estar en condiciones de apoyar la resistencia de los burgundios a la avanzada de los francos ${ }^{336}$. El panorama parecía auspicioso. Como gesto por la ayuda el rey Gundobado cedió Aviñón a los visigodos al

\footnotetext{
${ }^{335}$ Wolfram 1990, 173-189; Rouche 1979, 27-43.

${ }^{336}$ Greg. Tur., Hist., 2.33.
} 
año siguiente, mientras que en 502 Alarico II consiguió sellar un acuerdo paz con Clodoveo. No obstante, en solo un lustro la mayor parte de los dominios de la Galia se perderían a manos de los francos ${ }^{337}$.

Para Michel Rouche, los años previos a la batalla de Vouillé de $507^{338}$ habrían estado signados por una hostilidad creciente por parte de las aristocracias romanas católicas del reino hacia sus dominadores visigodos arrianos ${ }^{339}$. En consecuencia, la invasión por parte del recientemente bautizado Clodoveo habría sido recibida con beneplácito por las primeras. Su interpretación encuentra cierto correlato en el cuadro de situación que presenta Gregorio de Tours, quien señala que "muchos en la Galia estaban deseosos de tener a los francos como sus gobernantes" ${ }^{340}$. Pero la hipótesis es poco convincente. Los exilios sufridos por obispos católicos a manos de rey visigodo parecen haberse debido a razones políticas y no a la pretendida persecución religiosa (que Rouche retrotrae al gobierno de Eurico ${ }^{341}$ ). La promulgación de un extracto del Código Teodosiano, acompañado de interpretationes y la promoción de un concilio católico en la ciudad de Agde en el año 506, evidencian un entendimiento entre el rey Alarico II y amplios sectores de la aristocracia romana ${ }^{342}$. Finalmente, el obispo de Tours también señala que muchos auvernios participaron de la batalla de Vouillé al mando de líderes de rango senatorial (un testimonio que, por otro lado, apoya la hipótesis de la militarización de las antiguas aristocracias galo-romanas) ${ }^{343}$.

Aliado con los burgundios, Clodoveo invadió entonces el territorio visigodo en 507, pese a que el rey ostrogodo Teodorico el grande había amenazado con intervenir en favor de Alarico II si tal cosa ocurría ${ }^{344}$. Entre las bajas de los visigodos derrotados en Vouillé estuvo la de su propio rey, aparentemente asesinado por su par franco ${ }^{345}$.

\footnotetext{
${ }^{337}$ Greg. Tur., Hist., 2.35. Wolfram 1990, 189-192; Werner 1984, 344-345; Rouche 1979, 44-46.

${ }^{338}$ Se ha propuesto asimismo Voulon como sede del famoso conflicto. Véase Wood 2000, 518, en donde se retoma lo planteado en Gerberding 1987, 41.

339 Rouche 1979, 43: "Cette opposition forte à Tours, en Auvergne, en Arles et en Catalogne, espère l'appui et la conquête par Clovis et ses Francs".

${ }^{340}$ Greg. Tur., Hist., 2.35: "Multi iam tunc ex Galleis habere Francos dominos summo desiderio cupiebant". Sobre el bautismo de Clodoveo, véase Shanzer y Wood 2002, 362-373.

${ }^{341}$ Rouche 1979, 40-41.

${ }^{342}$ Barbero y Loring 2005, 173-174; Klingshirn 1994, 94-95.

${ }^{343}$ Greg. Tur., Hist., 2.37: "Porro rex, cum, fugatis Gothis, Alaricum regem interfecisse, duo ex adverso subito advenientes, cum contis utraque ei latera feriunt. Sed auxilio tam luricae quam velocis equi, ne periret, exemptus est. Maximus ibi tunc Arvernorum populus, qui cum Apollinare venerat et primi qui erant ex senatoribus corruerunt".

${ }^{344}$ Quienes impidieron la intervención ostrogoda fueron las fuerzas bizantinas, que por orden del emperador Anastasio desembarcaron en las costas italianas con el objetivo precisamente de distraer su atención (Moorhead 2005, 122).

${ }^{345}$ Greg. Tur., Hist., 2.37.
} 
Sobrevino de inmediato una crisis de sucesión en el reino, pues los dos hijos del difunto Alarico II, Gelasico y Amalarico, se disputaron el trono. Teodorico intervino, actuando supuestamente en protección de este último, que era nieto suyo y que no había cumplido aún la edad suficiente para asumir el trono. El rey ostrogodo colocó entonces a Theudis como general en Hispania a cargo de proteger al joven Amalarico y asumió el control del reino como regente de su nieto. Se discute si efectivamente Teodorico pasó a dominar un reino godo unificado o si el antiguo reino de Tolouse siguió teniendo una autonomía de facto $^{346}$. En cualquier caso, los visigodos lograron reconquistar parte de Aquitania poco después de la derrota de 507. La región seguía siendo teatro de operaciones militares $^{347}$.

Tiempo después se reanudó (una vez más) el conflicto entre francos y visigodos. A causa del fallecimiento de su abuelo en el año 526, Amalarico fue investido como rey de un Estado ahora sí indiscutiblemente independiente, con capital en Toledo. El aparente maltrato que venía ofreciéndole a su esposa Clotilde, hija de Clodoveo, dio a los merovingios la excusa perfecta para retomar las agresiones con posterioridad a su asunción $^{348}$. Amalarico acabó corriendo una suerte similar a la de su padre; fue derrotado y asesinado por tropas francas cerca de Narbona en 531. De todos modos, los visigodos lograrían retener el control de Septimania, incluso tras un nuevo intento de conquista comandada por Childeberto I en $541^{349}$.

Por otro lado, inmediatamente después de la batalla de Vouillé Teodorico había logrado arrebatar el control de Provenza a los burgundios, que estos habían obtenido gracias a su alianza con los francos ${ }^{350}$. La región volvió a tener entonces un prefecto, Liberio, que ocupó el cargo entre 510 y 534, lo que demuestra una cierta estabilidad política $^{351}$. De hecho, poco después se reemprendieron las acciones bélicas desde el territorio reconquistado. El asesinato de Sigerico por parte de su padre, el rey burgundio Segismundo, en el año 522 dio el pretexto esperado a Teodorico, abuelo de la víctima, para disfrazar de vendetta familiar una campaña militar que buscaba expandir los límites

\footnotetext{
${ }^{346}$ Barbero y Loring $(2005,175-176)$ destacan la independencia de Theudis frente al rey ostrogodo con quien, sin embargo, nunca llegaría a romper formalmente. Wolfram (1990, 192-193) se inclina por la idea de un control unificado en manos de Teodorico el grande.

347 Greg. Tur., Hist., 3.21. Se recuperó el sur de Novempopulana y posiblemente también Rodez y Tolouse (Wolfram 1990, 315).

${ }^{348}$ Greg. Tur., Hist., 3.10.

${ }^{349}$ Halsall 2007, 298-299; Barbero y Loring 2005, 179-180; James 1988, 92-93.

${ }^{350}$ Favrod 2002, 98-99.

${ }^{351}$ PLRE, 2, 677-681.
} 
del reino ${ }^{352}$. La empresa punitiva tuvo lugar entre ese año y el siguiente. A su corolario, el reino ostrogodo lograría la mayor extensión de su dominio provenzal, llegando más allá del Durance, posiblemente hasta el Isère ${ }^{353}$. De todos modos, la región sería finalmente cedida a los francos en $537^{354}$.

Como se ha podido constatar en este apartado, no se produjo una pacificación duradera de las regiones incorporadas al reino visigodo tras el cierre de las conquistas de Eurico. Veremos en el apartado final del presente capítulo cómo los conflictos militares afectaban no solo el territorio específico en el que tenían lugar los combates, sino también aquellos que estaban en el paso de los ejércitos. También observaremos que otras formas de violencia más cotidiana estuvieron a la orden del día en la Galia del periodo analizado. Estas cuestiones completan la información sobre conflictos puntuales y abonan las sospechas sobre la capacidad de las regiones para recuperarse económicamente de los estragos de la guerra.

Por otro lado, la relativa estabilidad política provenzal puede haber estado fundada sobre bases menos sólidas de lo que podría suponerse. Es cierto que la región continuó generando un excedente capaz de sustentar un aparato fiscal en funcionamiento. Asimismo, parece que el ingreso de mercancías a través del puerto de Marsella seguía siendo relevante ${ }^{355}$. Sin embargo, algunas fuentes ponen en evidencia las duras consecuencias de los enfrentamientos bélicos de los años 507-508. Teodorico debió ordenar ese último año el envío de trigo desde Italia para el aprovisionamiento del ejército porque la provincia estaba "agotada" ${ }^{356}$. Al año siguiente, o en 509, destinó un cargamento de grano y dinero como ayuda para la reconstrucción de murallas ${ }^{357}$ y en 511 dispuso la reducción de impuestos para la población de Arlés ${ }^{358}$. Por aquellos

\footnotetext{
${ }^{352}$ Mar. Avent., Chron., a. 522; Greg. Tur., Hist., 3.5.

${ }^{353}$ Wolfram 1990, 244 y 309-313.

354 James 1988, 94-96.

${ }^{355}$ Véase el capítulo 6.

${ }^{356}$ Cass., Var., 3.41: "Tritici itaque speciem, quam ob exercituales expensas nostra providentia de Italia destinavit, ne fatigata provincia huius praebitione laederetur, ad castella supra Druentiam constituta de Massiliensibus horreis constat esse portandam". Véase también Wolfram 1990, 312.

${ }^{357}$ Cass., Var., 3.44: “Quamvis primum sit laesos incolas refovere et in hominibus magis signum pietatis ostendere, tamen utrumque humanitas nostra coniungit, ut et largitatis remedio civibus consulamus et ad cultum reducere antiqua moenia festinemus. Sic enim fiet, ut fortuna urbis, quae in civibus erigitur, fabricarum quoque decore monstretur. Pro reparatione itaque murorum Arelatensium vel turrium vetustarum certam pecuniae direximus quantitatem. Victualia quoque, quae vestras relevare videantur expensas, fecimus praeparari, ut vobis destinentur, cum tempus navigationis arriserit. Relevate nunc animos et de nostra promissione recreati futurae copiae spem tenentes divino favore habetote fiduciam, quia non minus est quod nostris verbis quam quod horreis continetur".

${ }^{358}$ Cass., Var., 3.32: "Congruit comitatum nostrum viris nos decorare nobilibus, ut et illorum expleatur votum et obsequium nostrum ornent merita personarum. Proinde magnitudinem tuam ad conspectus
} 
tiempos, Cesáreo de Arlés denunciaba que algunos de quienes que no podían pagar sus obligaciones perdían sus tierras a manos de oportunistas ${ }^{359}$. Con todo, es posible que la región lograra cierta recuperación económica durante la pax ostrogoda de 508-536.

\section{EL REINO BURGUNDIO}

Se ha pretendido caracterizar a los reyes burgundios como más leales hacia las autoridades romanas que sus pares visigodos, incluso con posterioridad a la caída de la

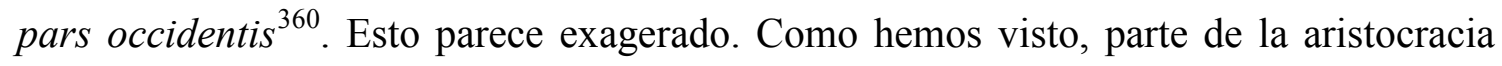
senatorial de la región lionesa que había sostenido al emperador Avito encontró el apoyo de los burgundios en su lucha contra Mayoriano. Es cierto que estos volverían al poco tiempo a ceñirse al foedus con el imperio ${ }^{361}$, pero años más tarde aparecían a ojos de Arvando como un actor autónomo en la región, capaz de expandir su autoridad más allá de sus fronteras. Finalizaba la década de 460 y los límites del reino ya se extendían allende Lyon y Vienne ${ }^{362}$. Nuevos avances territoriales se produjeron entre $469 \mathrm{y}$ $475^{363}$, mientras que la ruptura definitiva entre los burgundios y el gobierno imperial se dio recién tras la asunción de Julio Nepote a la púrpura, en el año $474^{364}$.

No es fácil reconstruir la historia política del reino durante el último cuarto del siglo $\mathrm{V}$. Una cuestión previa a tener en cuenta es que no imperaba el principio de la primogenitura en el traspaso de la soberanía entre los miembros de la dinastía gibichunga. De tal modo, el reino que era compartido hacia aquellas fechas por Gundioc y Chilperico I fue fragmentado nuevamente cuando tras la muerte del primero -ocurrida probablemente hacia 473 o 474 - se incorporaron como soberanos sus cuatro hijos

nostros, quos tibi non ambigimus esse gratissimos, his oraculis evocamus, ut qui longa nobiscum aetate versatus es, praesentiae nostrae dulcedine capiaris. Festinat enim ad principem, qui vel solum potest videre propitium: nam cui licet habere nostra colloquia, munera credit esse divina. Quapropter non tardamus desiderium, cuius optamus aspectum. Venire te gaudentem credimus, quem alacriter sustinemus".

${ }^{359}$ Caes., Serm., 154. Las prácticas denunciadas tienen similitudes con las que se describen en Salv., De gub. Dei, 5.37-45, aunque el contexto sociológico parece diferente. Trataremos más extensamente esta cuestión en el capítulo siguiente.

${ }^{360}$ Werner destaca 'l'impact de la loyauté romaine des rois burgundes sur l'histoire de leur royaume et de la Gaule" (1984, 329).

${ }^{361}$ Sid., Carm., 5.564-571; Halsall 2007, 262; Favrod 2002, 61-63.

362 Sid., Ep., 1.7.5; Favrod 2002, 65-66.

${ }^{363}$ Se anexan Valence, Die, Viviers, Gap, Embrun, St-Paul-Trois-Chateaux, Vaison, Orange, Sisteron, Apt, Cavaillon, Avignon. Favrod 2002, 67; Heather 2005, 527.

${ }^{364}$ Shanzer y Wood 2002, 16. 
(Godegisel, Chilperico II, Godomar y Gundobado) ${ }^{365}$. El detalle de los conflictos en torno a la sucesión del reino de Gundioc es oscuro. Se sabe que Gundobado eliminó en algún momento a Chilperico II y que logró subordinar a Godegisel, quien en 500 se alió con Clodoveo para desplazarlo ${ }^{366}$. La empresa tuvo éxito, aunque efímero, pues de inmediato Gundobado asedió Vienne, ciudad en donde se había asentado su hermano. Godegisel fue derrotado y muerto y se tomaron represalias severas para con su familia y la aristocracia que lo había apoyado. Con respecto al cuarto de los hermanos, Godomar, su ausencia en las fuentes posteriores daría cuenta de que ya no ejercía poder alguno desde al menos c. 500; es probable que Gundobado lo neutralizara de alguna forma. Por otro lado, este último heredó a su vez el reino del tío Chilperico I tras su fallecimiento, probablemente en $476^{367}$.

Al comenzar el siglo VI se produjo por lo tanto una monopolización del poder en manos de Gundobado. Su hijo Segismundo ocuparía un lugar de clara subordinación, a pesar de que poco después se lo invistiera como rey, una operación hecha seguramente con la intención de facilitar la sucesión al trono ${ }^{368}$. Por otro lado, parece que a partir de esos años comenzó un acercamiento entre Gundobado y Clodoveo, amenazados ambos en sus fronteras por los alamanes. Se selló así una alianza entre francos y burgundios que luego lograría derrotar a Alarico II y apoderarse de gran parte del reino de Tolouse. Los acontecimientos relacionados a dicha empresa y a la posterior represalia ostrogoda han sido comentados más arriba. Conviene en todo caso acentuar las consecuencias negativas que tuvo la derrota de 508 para los burgundios, quienes no solo sufrieron numerosas bajas al ser expulsados de los territorios conquistados, sino que además perdieron parte de sus antiguos dominios en la frontera meridional con los visigodos ${ }^{369}$.

El reino burgundio logró cierta recomposición en los años siguientes. Se acordó la paz con los ostrogodos, mientras que en el norte los alamanes fueron sometidos por los francos, con quienes seguía vigente la alianza previa ${ }^{370}$. Sin embargo, el escenario

\footnotetext{
${ }^{365}$ Al igual que Gundobado (véase el capítulo 1 de esta tesis), también Gundioc y Chilperico I gozaron de títulos oficiales del imperio romano (PLRE, 2, 523-524; V. Pat. Iur., 2.10).

${ }^{366}$ Mar. Avent., Chron., a. 500.

367 Shanzer y Wood 2002, 17; Halsall 2007, 300-301; Collins 2000, 115; Wood 2003, 253-254. La reconstrucción de Favrod (2002, 71-75 y 85-87) difiere en ciertos aspectos de las otras. En su opinión, solo Gundobado y Godegisel heredaron el reino de Chilperico I, que para ese momento había monopolizado el poder político. El primero habría ocupado en términos generales la región sur, mientras que a Godegisel le habría correspondido la parte septentrional.

${ }^{368}$ Shanzer y Wood 2002, 20-21.

${ }^{369}$ Favrod 2002, 90-91 y 96-99; Wolfram 1990, 311-312.

${ }^{370}$ Favrod 2002, 105.
} 
interno se alteró profundamente con posterioridad a la muerte Gundobado en 516. Primero se originó un conflicto con la Iglesia a raíz de un casamiento incestuoso por parte de uno de los cortesanos de Segismundo ${ }^{371}$ y luego, como hemos visto, sobrevino el enfrentamiento con los ostrogodos tras el asesinato de Sigerico (es probable que Segismundo temiese que su hijo estuviera complotando para derrocarlo ${ }^{372}$ ). El filicidio fue la excusa perfecta no solo para el avance militar de Teodorico, sino también para el del rey franco Clodomiro, uno de los hijos Clotilde -prima de Segismundo-, que además estaba casado con Guntheuca, probablemente una noble burgundia que podría haber estado vinculada familiarmente al fallecido ${ }^{373}$. Los francos vencieron a los burgundios y consiguieron apresar a Segismundo, a quien luego asesinarían junto con sus hijos y esposa. Asumió entonces el gobierno su hermano, quien pudo revertir el revés previo, derrotando y asesinando a Clodomiro en $524^{374}$. Fue en esa coyuntura cuando Teodorico aprovechó para hacerse con el control de los territorios situados al sur del Isère. No se descarta que los ataques de los francos y de los ostrogodos estuviesen coordinados $^{375}$.

Prácticamente todo lo que se sabe del gobierno de Godomar con anterioridad a la reanudación de los enfrentamientos con los francos proviene de una serie de disposiciones agrupadas en el Liber Constitutionem y las Constitutiones Extravagantes. Como veremos a continuación, el contenido de algunas de ellas daría a entender que el reino atravesaba un momento de particular inestabilidad social.

Finalmente, en 532, dos de los tres hijos vivos de Clodoveo, Childeberto y Clotario, reemprendieron el ataque al reino burgundio. Teuderico se rehusó a participar, probablemente porque estaba casado con la hija de Segismundo ${ }^{376}$. Los hermanos lograron algunas victorias modestas hasta que en 534 se les unió su sobrino Teudeberto, hijo de Teuderico, que a fines del año anterior había heredado el reino del padre ${ }^{377}$. La situación para el reino burgundio era sumamente crítica, pese a que los ostrogodos habían decidido restituirles el territorio arrebatado en 524 (con excepción de las

\footnotetext{
${ }^{371}$ Shanzer y Wood 2002, 23-24.

372 Collins 2000, 116.

${ }^{373}$ Favrod 2002, 113-114.

${ }^{374}$ Mar. Avent., Chron., aa. 523 y 524. Greg. Tur., Hist., 3.5-6.

${ }^{375}$ Halsall 2007, 303.

${ }^{376}$ Greg. Tur., Hist., 3.11.

${ }^{377}$ Greg Tur., Hist., 3.23.
} 
ciudades entre el Isère y el Durance $)^{378}$. Necesitado de apoyo externo, Godomar buscó una alianza con los visigodos, al punto de prometer la subordinación a su rey ${ }^{379}$. Esto no logró impedir su derrota en 534 frente a los tres reyes francos aliados, quienes se dividieron el reino ${ }^{380}$.

Como ha podido observarse, el territorio encuadrado dentro del reino burgundio experimentó varios vaivenes político-militares durante el periodo analizado. En la región norte, cerca de las ciudades de Langres y Besançon, el prolongado conflicto con los alamanes tuvo repercusiones en la vida social de la región. Libres y esclavos fueron rescatados y capturados de territorio enemigo con la suficiente asiduidad como para hacer necesaria la legislación sobre determinados problemas derivados de esas prácticas $^{381}$. Por otro lado, en la Vita Eugendi se hace referencia a las incursiones de los alamanes y a cómo los monjes preferían buscar la sal para cocinar en las costas del Mediterráneo antes que en las salinas cercanas al enemigo ${ }^{382}$.

Esta última anécdota podría dar a entender que existía una mayor estabilidad económica en el sur, que daría sustento a la existencia de un comercio relativamente fluido a través del curso del Ródano hasta Marsella. Como veremos más adelante el registro arqueológico evidencia, sin embargo, una transformación en las características de los intercambios en la región durante el periodo estudiado ${ }^{383}$. Además, existen otros indicios que apuntan en dirección contraria. Hacia fines del siglo $\mathrm{V}$ se produjo un acuerdo entre Teodorico el grande y Gundobado para liberar unos prisioneros ligures esclavizados años atrás, campesinos que habían resistido una avanzada burgundia en territorio italiano en la coyuntura del enfrentamiento entre el primero y Odoacro en 489-

\footnotetext{
${ }^{378}$ El objetivo de los ostrogodos era seguramente proteger mejor el paso entre sus dominios provenzales e Italia ante un eventual ataque de los francos (Favrod 2002, 126). Luego de la muerte de Teodorico el grande en 526, el reino ostrogodo había sido heredado por su hija Amalasunta.

${ }^{379}$ Favrod 2002, 126.

${ }^{380}$ Mar. Avent., Chron., a. 534; Greg. Tur., Hist., 3.11; Halsall 2005, 302-303; James 1988, 94. Debe tenerse en cuenta que Gregorio de Tours confunde las fechas. Wood $(1994,52)$ propone seguir la cronología sugerida por Mario de Avenches.

${ }^{381}$ Lib. Const., 56.1-2: "[1] Si quis servum alienum in Alamannia redemerit, aut pretium dominus red dat, aut servum habeat qui redemit; quod tamen a praesenti tempore praecipimus custodiri. [2] Ceterum si ingenuus rogans redemptus fuerit, pretium suum emptori reddat".

${ }^{382}$ V. Pat. Iur., 157: "Quadam namque vice, dum diros metuunt ac vicinos Alamannorum incursus, qui inopinatis viantibus non congressione in comminus, sed ritu superventuque solent inruere bestiali, ad mortem aut suspicionem mortis penitus evitandam, quae crebro timoris iaculo totiens interimit, quotiens timetur, e limite Tyrreni maris potius quam de vicinis Aeriensium locis coctile decernunt petere sal'. Se menciona erróneamente el mar Tirreno en lugar del Mediterráneo. Las tres hagiografías contenidas en las Vitae Patrum Iurensis fueron compuestas probablemente c. 520, poco después de la muerte de Eugendo (Vivian, Vivian y Russell 1999, 51).

${ }^{383}$ Véase el capítulo 6 de esta tesis.
} 
490. Parece ser que el acuerdo benefició políticamente a Gundobado porque a cambio de los cautivos el rey ostrogodo ofreció a su hija en matrimonio con Segismundo. Lo interesante del episodio, que nos ha llegado a partir de un testigo presencial de la negociación, es que el traspaso habría afectado seriamente los campos, que estaban siendo trabajados por los prisioneros. Seis mil fueron los liberados sin reembolso, mientras que otros tuvieron que ser rescatados a cambio de metálico. Justin Favrod plantea que esta última operación habría posibilitado la compra de otros esclavos, solucionando así el problema de la falta de brazos, pero ello no constituye más que un supuesto. En cualquier caso, a la luz del contexto más general, la anécdota se suma a toda una serie de testimonios sobre constantes capturas, compras y ventas de esclavos entre unas regiones y otras de la Galia que abona la idea de una fuerte inestabilidad en las relaciones de explotación en el área ${ }^{384}$.

Para Karl Ferdinand Werner, la correspondencia de Avito de Vienne (494-518) demostraría que la vida de los senadores romanos en el reino burgundio había permanecido inalterada y segura gracias a la presencia de un gobierno sólido ${ }^{385}$. Sin embargo, la persistencia de los conflictos militares internos y externos tuvo consecuencias directas sobre la vida social en la región meridional. Algunos acontecimientos en particular causaron grandes daños, como la "reconquista" de Provenza por parte de los ostrogodos o, más puntualmente, el asedio de Vienne en 500, que culminó con una matanza de la población urbana ${ }^{386}$. Es posible que hasta c. 520 haya existido una cierta permanencia de algunos núcleos de dominación social heredados de la época tardo-romana, pero una serie disposiciones legales sancionadas durante el reinado de Godomar dan cuenta de una situación social inestable. Abundan en ellas las referencias a cautivos, esclavos perdidos (vendidos, robados o fugados) y migrantes $^{387}$; problemas en el abastecimiento comercial $^{388}$ e inconvenientes para

\footnotetext{
${ }^{384}$ Enod., V. Epiph., 171-181: “[171] Post praeceptum venerandi regis inpiger ille verborum saltibus indulgentiae species aut formas exposuit et chartas ad insignem antistitem detulit. Quas ille cum expectatissima devotione suscepit et portitorem tanti doni ambienter amplexus est. Qui postquam rumor innotuit, tanta istius iam liberae multitudinis frequentia subito adstitit, ut desolata crederes esse etiam incolis rura Gallorum". Favrod 2002, 81-82. Enodio de Pavía formó parte de la delegación que negoció el rescate.

${ }^{385}$ Werner 1984, 329.

${ }^{386}$ Greg. Tur., Hist., 2.33; Av., Ep., 46A, 94 y 95.

${ }^{387} \mathrm{Si}$ un cautivo burgundio regresaba al reino, podía reclamar sus antiguos esclavos en caso de que se los hubiese apropiado un pariente (Const. Ext., 21.2: "Si quis ingenuus in captivitatem ductus est, et mancipia intra regione nos in regno nostrotra reliquit, quicumque mancipium propinquitatis ad se revocavit, aut praesumpsit aut forsitan per nostram praeceptionem petiit, si captivus ille ad propria redierit, mancipia sua absque praeiudicio pasta recipiat"); si un esclavo vendido al extranjero regresaba, debía permanecer
} 
controlar al funcionariado estatal ${ }^{389}$. Por otro lado, varias disposiciones anteriores reunidas tanto en el Liber Constitutionem hacían alusión a fugas de esclavos ${ }^{390}$.

\section{LA EXPANSIÓN FRANCA}

En el capítulo anterior el análisis de la situación del norte de Galia se interrumpió en el momento en que las fuerzas visigodas se aprestaban a atacar a Egidio. La batalla tuvo lugar en Orleans en 463; las fuerzas de Federico, hermano del rey Teodorico II fueron derrotadas por el general romano, al mando de un ejército conformado por francos ${ }^{391}$. Egidio murió al año siguiente en circunstancias que no quedan claras pero que algunos historiadores han relacionado con el hecho de que poco

en libertad pudiendo únicamente estar bajo patrocinium de su antiguo amo (Const. Ext., 21.3: "Quicumque servum suum aut ancillam de regione nostra in sortem alienam vendiderit, more patriae mancipium venditum ad propria redierit, ut libertus sit, ordinamus; ea tamen ratione, ut non alterius patrocinium nisi domini illius, qui eum vendiderit, habiturum esse cognoscat"); si alguien había perdido todos sus esclavos en tiempos de saqueos, quedándose solo con una esclava, debía protegerla si la liberaba para tomarla como esposa (Const. Ext., 21.5: "De eo vero, qui tempore excidii ad fidem inimicorum amissis mancipiis cum una tantum ingenua persona, quam in loco uxoris sibi liberavit, egressus est: is, qui eam liberavit, mercedes requirere specialius ordinamus, ut nihil penitus ad mulierem illam de tali causa queratur"); si un godo o cualquier persona deseaba ingresar al reino para establecerse, no debía esclavizársele (Const. Ext., 21.4: "Quicumque ingenuus de Gotia captivus a Francis in regione nostra venerit et ibidem habitare voluerit, ei licentia non negetur"; Const. Ext., 21.6: "Quicumque persona de alia regione in nostram venerit et ibi voluerit habitare aut cum quo esse voluerit, habeat licentiam, et nullus eum ad servitium aut per se addicere praesumat aut a nobis petere conetur"); si alguien compraba el esclavo de otro a un franco, debía devolvérselo a cambio del precio pagado por dicho esclavo al franco en cuestión (Const. Ext., 21.9: "Quicumque mancipium alienum de Francis conparaverit, testibus idoneis hoc adprobet, quantum et quale pretium dederit, et hoc testes illi iurati dicant: 'Nobis praesentibus pretium dare vidimus; sed nec ille, qui mancipium conparavit, nullam fraudem aut conludium cum inimicis fecit'. Quod si testes idonei taliter sacramenta dederint, quantum pretium dedit, tantum recipiat; nec pastum requirat, et mancipium cuius fuerat sine mora reddatur").

${ }^{388}$ En Const. Ext., 21.7 se establecía que los comerciantes estaban obligados a aceptar cualquier tipo de solidus (excepto cuatro acuñaciones en particular) o su peso en oro y que de no hacerlo no tenían derecho a reclamar la restitución de la mercadería ("De monetis solidorum [iubemus] custodire, ut omne aurum, quodcumque quicumque praeter istas quattuor monetas aurum pensantem non acceperit, id, quod vendere volebat, non accepto pretio perdat"). Favrod 2002, 122 interpreta esto como desorganización comercial. La medida es oscura, pero parecería indicar problemas en el abastecimiento de productos indispensables en un contexto de desvalorización del metálico como medio de compra.

${ }^{389}$ La Const. Ext., 21.11 instaba a todos los condes a imponer duros castigos a quienes cometieran cualquier tipo de delito (véase la transcripción en el capítulo 6, n. 739). Quienes sancionaban la disposición (la asamblea de burgundios reunida en Ambérieux) denunciaban que los condes favorecían a sus parientes promoviendo la reiteración del delito.

${ }^{390}$ Lib. Const., 6.4, 20.1-4, 39.2, 39.4-5 y 57. Otras normas tratan sobre fugitivi sin aclarar su status social: Lib. Const., 6.1-3, 6.5-10 y 39.3. La cantidad de disposiciones es similar a la contenida en el edicto del rey Rotario del año 643, que Bonnassie considera muy elevada (1991, 64). Véase también Av., Ep., 44, concerniente a la fuga de un esclavo.

${ }^{391}$ Hyd., Chron., 218; Chron. Gall. a. DXI, 638; Mar. Avent., Chron., a. 463. 
antes Childerico hubiese conseguido regresar de un exilio de ocho años en Turingia y hacerse con una posición de mando en la región del Loira ${ }^{392}$.

No resulta sencillo desentrañar cuál fue el alcance del poder ejercido por este último en los años siguientes. A través de una carta de Remigio, obispo de la ciudad de Reims, dirigida a Clodoveo cuando ya era rey, cabría deducir que Childerico, su padre, había gobernado al menos la región de Bélgica Secunda con un carácter más o menos formal $^{393}$. Por otro lado, en la Vita Genovevae se sostiene que durante una década el rey franco mantuvo un asedio sobre la ciudad de París ${ }^{394}$. En base a estos pocos datos, Edward James ha sugerido que Childerico gozó de una posición más o menos oficial dentro de la estructura de gobierno en el norte de la Galia antes de su muerte, en torno al $481^{395}$.

También es oscura la posición ocupada por Siagrio. No hay fuente contemporánea que lo mencione y lo que se sabe a través de Gregorio de Tours es que habría sido un rex romanorum como su padre Egidio y que estableció su residencia en Soissons. El obispo nos informa asimismo que libró una batalla contra Clodoveo en la que fue derrotado y que luego lo asesinaron antes de que pudiese conseguir asilo político con Alarico $\mathrm{II}^{396}$. Como ha planteado James, nada hace suponer, como se pretendió durante algún tiempo, que Siagrio estuviese a la cabeza de un reino con sede en Soissons, ni mucho menos que dicho reino se extendiese por todo el norte de la Galia $^{397}$. Esa idea se sustentaba más en la necesidad de llenar un vacío en el conocimiento sobre qué había sido de la región en términos políticos que en información precisa. Este historiador propuso que Siagrio podría haber sido simplemente el comes de Soissons, de la misma manera que otros lo habían sido de otras ciudades. Gregorio de Tours habría tenido en todo caso cierto interés en elevar la posición de Siagrio a rex para así magnificar la victoria de Clodoveo ${ }^{398}$. Por su parte, Werner sugirió que Childerico podría haber sido el comandante de un exercitus franco federado apegado a la autoridad de Siagrio, quien habría heredado una verdadera Romania constituida por Egidio con posterioridad a que Ricimero decidiese aliarse con

\footnotetext{
${ }^{392}$ Hyd., Chron., 228; Greg. Tur., Hist., 2.18-19 (el obispo recupera en estos fragmentos pasajes perdidos de los Anales de Angers). Halsall 2007, 269.

${ }^{393}$ Ep. Aust., 2.

394 V. Gen., 6.25 y 7.34.

${ }^{395}$ James 1988, 65-67; Halsall 2007, 270.

${ }^{396}$ Greg. Tur., Hist., 2.18 y 2.27 .

${ }^{397}$ E. g. Geary 1988, 82-83.

${ }^{398}$ James 1988, 70-71 y 79; Lebecq 1990, 47.
} 
los visigodos para atacar el norte galo ${ }^{399}$. Pero este argumento choca con las evidencias que hemos visto acerca del dominio del propio Childerico en la región. Resulta entonces más convincente la reconstrucción de James, para quien entre los años 465 y c. 481 la situación política por encima de los gobiernos de cada una de las civitates por parte de condes como Arbogasto ${ }^{400}$ u obispos como Remigio no estaba todavía definida. Childerico habría sido entonces más bien un jefe entre otros, en una Galia septentrional en la que al menos existían otros dos focos de poder: el de los bretones en occidente y el los francos renanos en oriente) ${ }^{401}$. En cualquier caso, la situación política y militar fue mucho más dinámica e inestable de lo que propone un continuista como Werner. Sin una autoridad superior en la región tras la caída del imperio, la aristocracia gala, los comandantes del ejército romano y los jefes bárbaros disputaron el dominio local ${ }^{402}$, aunque en muchos lugares tanto los soldados de las fuerzas "romanas" como sus comandantes fueran francos desde hacía mucho tiempo ${ }^{403}$. Las conquistas de Clodoveo deben analizarse entonces contra este fondo de dominio supralocal en discusión.

Gregorio de Tours presenta la empresa militar del hijo de Childerico como si se hubiese tratado de un proceso conformado por batallas puntuales, pero es muy probable que, por el contrario, haya consistido en campañas prolongadas ${ }^{404}$. Clodoveo se hizo primero con el control político de su radio de acción inmediato, eliminando al menos a Siagrio en 486. En los años siguientes avanzó contra sus vecinos. Hemos analizado con cierto detenimiento el largo conflicto sostenido con el reino de Tolouse, así como las alternancias de alianzas y hostilidades (con triunfos y reveses) que se mantuvieron con los burgundios. Clodoveo también arremetió contra alamanes y turingios, logrando expandir considerablemente sus dominios orientales. Por otro lado, procuró en los años previos a su muerte la eliminación sistemática de parientes y otros reyes francos como Sigiberto el Cojo, Chararico y Ragnacharo con la intención de concentrar la autoridad en un único Estado ${ }^{405}$.

\footnotetext{
${ }^{399}$ Werner 1984, 321-322.

${ }^{400}$ Sobre su gobierno en Tréveris, véase Sid., Ep., 4.17.

401 James 1988, 72-77.

${ }^{402}$ Van Dam 2005, 196, aunque en nuestra opinión el autor tiende a exagerar el entendimiento entre estos sectores ("Gallic aristocrats and Roman commanders joined barbarian chieftains in asserting their local influence”). Véase también Wood 1994, 38-39.

${ }^{403}$ Werner 1984, 301-302.

${ }^{404}$ James 1988, 80.

${ }^{405}$ Greg. Tur., Hist., 2.27-43. Además de la bibliografía referida oportunamente en el análisis de las guerras con visigodos y burgundios, véase para las conquistas en general Werner 1984, 342-350; James
} 
La partición del reino tras la muerte de Clodoveo en el año 511 parece haber sido una decisión sin precedentes para la monarquía franca y pudo haberse debido a la situación política vigente en dicho momento. Clotilde, su esposa burgundia, quería asegurar la herencia de sus descendientes, Clodomiro, Childeberto y Clotario, que eran menores, pero no podía pasar por alto la presencia del primogénito de Clodoveo, Teuderico, que ya era un líder militar de importancia ${ }^{406}$. Las disputas entre los hermanos lograron allanarse fragmentando en cuartos el gran dominio establecido por su padre y canalizando la necesidad de emprender la guerra a través de una nueva política expansiva $^{407}$. Por lo tanto, la omnipresencia del conflicto militar que había sido atributo del largo reinado de Clodoveo no se modificó en los años subsiguientes. Hemos hecho mención ya a la reanudación de los enfrentamientos con los visigodos y los burgundios -cuyo reino se conquistó definitivamente en 534- y la obtención de Provenza tras su cesión por los ostrogodos. También se produjeron avances militares en el norte y el este ${ }^{408}$.

La rápida evocación de los sucesos puede soslayar el impacto que estos conflictos prolongados tuvieron en las poblaciones que los sufrieron. Cabe detenernos en la descripción de un episodio en particular a título ilustrativo: la incursión de las fuerzas de Teuderico sobre Auvernia hacia el año 525. El hecho tuvo lugar dentro del área que hemos decidido privilegiar en este estudio. Gregorio de Tours refiere que los francos que se encontraban bajo el mando de Teuderico habían amenazado con mudar a otro su lealtad si no accedía a acompañar a sus hermanos en la ofensiva contra los burgundios $^{409}$. El reclamo apuntaba a un aspecto central del funcionamiento de la realeza: la conducción del séquito armado a la guerra. Teuderico satisfizo las quejas permitiendo a su ejército atacar un territorio que estaba bajo su dominio, pero cuyas aristocracias estaban mostrándose díscolas ${ }^{410}$. El caso pone así en evidencia la importancia de la guerra en la dinámica política franca. Gregorio escribe que Clermont y su región circundante fueron saqueadas y destruidas y que el rey dio vía libre para la obtención de cualquier clase de botín que los soldados desearan (metálico, esclavos,

1988, 79-88; Halsall 2007, 303-309; Lebecq 1990, 46-51 y 53-57. Sobre la concentración del poder y la matanza de parientes, consúltese James 1988, 88-91 y Lebecq 1990, 58.

${ }^{406}$ Wood 1994, 50.

${ }^{407}$ Lebecq 1990, 61-64; Halsall 2007, 309.

408 James 1988, 96-107.

409 Cabe señalar que Gregorio de Tours confunde las fechas. Como ha sugerido James (1988, 94), se trataba del primer ataque a los burgundios (523) y no del segundo (534).

${ }^{410}$ Greg. Tur., Hist., 3.9. 
ganado, etc.) ${ }^{411}$. Podría tratarse de un relato intencionalmente exagerado; sin embargo contamos con un documento proveniente de aquella ciudad y datado en el periodo inmediatamente siguiente que resulta revelador pues es el formulario a presentar ante las autoridades por aquellos que habían perdido tierras a manos de los francos durante los ataques y pretendían una restitución formal ${ }^{412}$.

Al promediar el siglo VI ya se encontraban conformadas las tres grandes unidades políticas que con cambios menores continuarían teniendo vigencia durante todo el periodo merovingio: Neustria, Austrasia y Burgundia ${ }^{413}$. Pero no deberíamos exagerar esta coherencia, pues los conflictos internos de la dinastía merovingia continuarían tras la breve unificación alcanzada por Clotario entre 558 y 561, afectando negativamente la estabilidad política de cada una de esas tres grandes entidades más allá de las aparentes continuidades ${ }^{414}$. En el caso de Aquitania y Provenza, por otro lado, las fragmentaciones fueron mayores y más arbitrarias cuando pasaron a depender de los reinos del norte ${ }^{415}$. En la base de todo el proceso se halló la necesidad del rey de proporcionar tierras, botín y honores a los sectores aristocráticos laicos y eclesiásticos, como observaremos a continuación ${ }^{416}$.

\footnotetext{
${ }^{411}$ Greg. Tur., Hist., 3.11 ("Post haec Chlothacharius et Childeberthus Burgundia petere distinant. Convocatusque Theudoricus in solatio eorum, ire noluit. Franci vero, qui ad eum aspiciebant, dixerunt: 'Si cum fratribus tuis in Burgundiam ire dispexeris, te relinquimus et illos sequi satius praeoptamus'. At ille infidelis sibi exhistimans Arvernus ait: 'Me sequimini, et ego vos inducam in patriam, ubi a aurum et argentum accipiatis, quantum vestra potest desiderare cupiditas, de qua pecora, de qua mancipia, de qua vestimenta in abundantiam adsumatis. Tantum hos ne sequamini!' His pro missionibus hi inlecti suam voluntatem facere repromittunt. Ille vero illuc transire disponit, promittens iterum atque iterum exercitu cuncta regionis praedam cum hominibus in suis regionibus transferre permittere") y 3.12 ("Theudoricus vero cum exercitu Arverno veniens, totam regionem devastat ac proterit [...] Theudoricus ad urbem Arvernam usque accedens, in vici illius suburbana castra fixit. Beatus vero Quintianus his diebus erat episcopus. Interea exercitus cunctam circuit miseram regionem illam, cuncta delet, universa debellat. De quibus nonnulli ad basilicam sancti Iuliani perveniunt, confringunt ostia, seras removent resque pauperum, quae ibidem fuerant adgregatae, diripiunt et multa in hoc loco perpetrant mala").

${ }^{412}$ Form. Arv., 1: "Ob oc igitur ego ille et coiuves mea illa conmanens orbe Arvernis, in pago illo, in villa illa, dum non est incognitum, qualiter cartolas nostras per hostilitatem Francorum in ipsa villa illa, manso nostro, ubi visi sumus manere, ibidem perdimus...".

${ }^{413}$ Werner 1984, 362-365; Geary 1988, 119-122.

${ }^{414}$ Sobre las fragmentaciones de los reinos francos entre 561 y c. 590, véase James 1988, 169-182. En cuanto al conflicto civil entre los merovingios, consúltese Wood 1994, 88-101. Por otro lado, las entidades estatales francas de $c$. 550 estaban lejos de tener controladas ciertas regiones como Armórica o Gasconia que ocasionalmente generaban inconvenientes (Lebecq 1990, 71-72).

${ }^{415}$ Wood 1994, 55.

${ }^{416}$ Para James (1988, 169-172), la guerra civil entre los francos se tornó en desenlace inevitable cuando la necesidad de los reyes de premiar con tierras, oro y lujos a sus séquitos se combinó con el fuerte imperativo moral de resolver por medio de la violencia cualquier afrenta a la honra de la familia.
} 


\section{LA GUERRA PERMANENTE}

En este apartado analizaremos las consecuencias sociales que tuvieron los conflictos militares mencionados, particularmente en la región y periodo de nuestro interés. A tal efecto, es oportuno retomar en primer lugar a Georges Duby, quien señaló hace ya varias décadas que el mundo de la temprana Edad Media estuvo dominado por el hábito del saqueo y por las necesidades de la oblación, y que la principal misión del rey o del jefe militar era la de conducir a su ejército a la obtención de botín, estuviese compuesto este de alimentos, esclavos, tierras u objetos suntuarios. El producto de la guerra debía compartirse para reforzar el vínculo de reciprocidad entre quien detentaba la autoridad y quienes lo secundaban ${ }^{417}$, aunque eventualmente los reyes podían reservarse tajadas más importantes, por ejemplo para ser dadas a las iglesias con el fin de congraciarse con Dios ${ }^{418}$. Pero la práctica del don se extendía más allá del estricto reparto del botín, pues a cambio de lealtad se esperaba del rey una generosidad constante. Las relaciones de don y contra-don animaban el sistema político, obligando a los soberanos a reanudar periódicamente la maquinaria bélica so pena de ver vaciados sus tesoros y, consecuentemente, diluido su poder sobre los hombres ${ }^{419}$.

Este orden de cosas puede observarse en los reinos de la Galia del siglo VI. Ni los reyes ni los aristócratas atesoraban con fines acumulativos o para invertir productivamente, sino para poder obsequiar, buscando con ello generar obligaciones ${ }^{420}$. Se consideraba un buen monarca aquel que daba bienes y honores. Por el contrario, uno que expropiaba tierras de sus súbditos en lugar de obsequiarlas o no se mostraba generoso era visto negativamente ${ }^{421}$. Esta dinámica impulsaba tanto la guerra hacia

\footnotetext{
${ }^{417}$ Analizaremos en el capítulo 5 el proceso de militarización de las aristocracias.

${ }^{418}$ Obsérvese en este sentido el famoso episodio en el que Clodoveo reclamó a los miembros de su séquito armado un vaso perteneciente a la iglesia de Soissons que había sido obtenido como producto de la guerra con Siagrio. El pedido implicaba violar el principio de reparto equitativo del botín, pero solo uno de los soldados se opuso al rey, rompiendo el objeto en señal de defensa del uso tradicional. Clodoveo se vengó finalmente partiéndole la cabeza de un hachazo (Greg. Tur., Hist., 2.27: "Dehinc adveniens Sexonas, cunctum onus praedae in medio positum, ait rex: 'Rogo vos, o fortissimi proeliatores, ut saltim mihi vas istud' -hoc enim de urceo supra memorato dicebat, - 'extra partem concidere non abnuatis'. Haec regi dicente, illi quorum erat mens sanior aiunt: 'Omnia, gloriose rex, quae cernimus, tua sunt, sed et nos ipsi tuo sumus dominio subiugati. Nunc quod tibi bene placitum viditur facito; nullus enim potestati tuae resistere valet'. Cum haec ita dixissent, unus levis, invidus ac facilis, cum voce magna elevatam bipennem urceo inpulit, dicens: 'Nihil hinc accipies, nisi quae tibi sors vera largitur"').

${ }^{419}$ Duby [1973], 61-72; más recientemente Smith 2005, 198-214. Consúltese Halsall 2003, 30-31 y 36-39 para la relación entre guerra y política.

${ }^{420}$ Greg. Tur., Hist., 7.3.

${ }^{421}$ Greg. Tur., Hist., 3.25 y 6.46; Fred., Chron., 4.60.
} 
fuera en busca de botín, como el saqueo y las confiscaciones dentro del propio territorio. Lógicamente esta última vía alimentaba los conflictos internos, pero a la vez podía transformarse en el corto plazo en un arma más efectiva de promoción individual de las elites (a través del desplazamiento de rivales directos) y de consolidación del poder de los reyes (mediante la promoción de la lucha facciosa interaristocrática) ${ }^{422}$.

Es importante tener presente esta característica central de la dinámica política para comprender el carácter dual de la guerra durante el periodo, a la vez como estabilizadora de los vínculos entre reyes, aristócratas y soldados en el corto plazo y como perturbadora del orden social en la larga duración, dada su frecuencia. Nos será de suma utilidad para el abordaje de esta última cuestión retomar algunas líneas argumentales de un reciente estudio de Guy Halsall dedicado a la guerra en Europa occidental en el periodo c. 450-c. 900. En dicho trabajo, el autor se aleja de las perspectivas más tradicionalistas de la historiografía militar para estudiar el problema bélico en su íntima vinculación con el más amplio contexto socioeconómico, sociopolítico y religioso ${ }^{423}$.

Halsall coincide con Duby en destacar la omnipresencia de la guerra. Sostiene además que los conflictos bélicos variaban en escala e incluso en sus objetivos inmediatos, pero que en la generalidad de los casos los jefes militares planificaban campañas de corta duración en busca de botín ${ }^{424}$. Recordemos en este sentido las apreciaciones de James sobre la empresa de conquista de Clodoveo, edificada a partir de muchas pequeñas batallas. Por otro lado, Halsall señala dos cuestiones de suma importancia: por un lado, el arraigo en las comunidades temprano medievales de formas de violencia "menores" como robos, peleas y otros delitos abundantemente tratados en los códigos legales; por otro, la fuerte presencia de bandas armadas que en tiempos de guerra formaban parte medular de los ejércitos, pero que en tiempos de "paz" podían actuar como salteadores ${ }^{425}$. Ambos fenómenos aparecen reflejados en la documentación del siglo VI en la Galia. El Liber Constitutionem está plagado de referencias a delitos

\footnotetext{
422 Devroey 2003, 180-186 y 246.

${ }^{423}$ Halsall 2003, 10. Conviene destacar que el análisis del autor parte de una caracterización general del periodo y de las regiones analizadas en su estudio similar a la sostenida por Wickham (2005). Vale decir que en su opinión se trató de una época de fuerte contracción económica, que se originó primero en las antiguas provincias romanas del noroeste (c. 400) y que posteriormente se dio en las regiones meridionales de Hispania, Italia y Galia del sur (c. 550) (Halsall 2003, 125-128 y 160-161). Como quedará claro a lo largo de esta tesis, estamos de acuerdo con esta postura rupturista, aunque con matices. ${ }_{424}$ Halsall 2003, cap. 7 (esp. 140-143).

${ }^{425}$ Halsall 1998; 2003, 15.
} 
menores ${ }^{426}$. Para Provenza contamos con el testimonio de Cesáreo de Arlés, varios de cuyos sermones versan sobre robos y conflictos cotidianos ${ }^{427}$. Finalmente, la ubicuidad de las bandas armadas queda patente en los Decem libri historiae ${ }^{428}$. Aunque muchas de las menciones a las mismas que hace Gregorio de Tours pertenecen al periodo posterior a c. 550 y abarcan la totalidad de la Galia, consideramos que son extrapolables al periodo y región tratados en esta tesis, para el que contamos con un puñado de referencias en las cartas de Sidonio Apolinar y algunas leyes imperiales ${ }^{429}$.

Es probable que los ejércitos del periodo fueran reducidos en comparación con los tardo-romanos ${ }^{430}$. Sin embargo, esto no iba en desmedro del poder de hacer daño a la población civil, tanto urbana como rural. Además de los casos ya referidos en los apartados anteriores, Gregorio de Tours menciona otros posteriores que dan una idea clara del perjuicio que podía causar el simple paso de una comitiva armada por el territorio franco: matanzas, robo de animales, quema de edificios, etc ${ }^{431}$. El área rural sufría incluso las consecuencias de las operaciones militares enfocadas en la captura de ciudades, pues la estrategia más utilizada para conseguir su rendición o forzar que el enemigo guarecido intramuros presentase batalla era el saqueo del área circundante ${ }^{432}$. Podemos ilustrar esto con una referencia concerniente a la campaña de conquista de Clodoveo sobre el reino burgundio. Gregorio de Tours narra la invectiva de Gundobado y un hombre de su confianza, Aredio, para evitar que el rey franco continuase asediando la ciudad de Aviñón en la que estaban refugiados. Simulando ofrecerse como servidor, Aredio le sugirió a Clodoveo que en lugar de continuar con una expoliación que estaba

\footnotetext{
${ }^{426}$ Véanse por ejemplo los títulos 4 (robos), 5 (golpizas), 6 (fugas), 12 (raptos), 15 (peleas), 20 (robos hechos por fugitivos), 25 (robos y actos violentos) y 30 (violaciones). También abundan las referencias a delitos menores en el Pactus legis salicae, aunque estas nos interesan menos en tanto nos informan sobre la realidad del norte y noreste de la Galia.

${ }^{427}$ Caes., Serm., 13.2-3, 14.2, 16.3, 19.3, 50.3, 51.2, 60.2 y 154.2.

${ }^{428}$ Greg. Tur., Hist., 3.35, 4.13, 4.36, 5.18, 5.49, 6.4, 6.11, 6.16-17, 7.3, 7.19, 7.22, 7.29, 7.33, 7.47, 8.18, $8.32,9.10,9.19,9.35,9.40-41,10.5,10.12$ y 10.15 .

${ }_{429}$ Sid., Ep., 1.6, 3.3, 4.20, 6.4 y 8.6; C. Th., 7.18.14 y 9.14.2; Nov. Val., 9.1.

${ }^{430}$ Halsall 2003, cap. 5. Según sus cálculos, el número de soldados de un gran ejército de los siglos VIVII en el mundo franco debió de haber rondado los 5.000 o 6.000 hombres, es decir, una cifra muy menor a la de la época tardo-romana (p. 132).

${ }^{431}$ Greg., Tur. Hist., 4.42, 5.4, 6.45, 7.24, 7.35, 7.38, 8.30, 9.12 y 10.3 .

${ }^{432}$ Halsall 2003, 137-140. El fenómeno del asedio a ciudades fue particular del periodo merovingio, pero no porque las ciudades fueran prósperos centros económicos, sino a causa de que muchas de ellas continuaron siendo centros administrativos en tanto capitales de civitates. Muchas veces se buscaba forzar la lealtad de la región a través de la sumisión de las autoridades de su cabecera.
} 
arruinando los campos exigiese un tributo anual a Gundobado. Los saqueos durante este acontecimiento se ven corroborados por una carta de Avito de Vienne ${ }^{433}$.

Hemos mencionado anteriormente que el sitio de Vienne del año 500 finalizó con una matanza de su población urbana. En la generalidad de los casos, sin embargo, este no era un objetivo buscado en los asedios, que como se dijo pretendían forzar la derrota del enemigo a través de la negociación o de la lucha en el campo de batalla ${ }^{434}$. Esto explicaría para Halsall la aparente paradoja de que en una época en la que el ataque a las ciudades estaba a la orden del día las murallas estuviesen tan descuidadas. Sin embargo, en su interpretación la contracción económica y el desinterés por la toma de las ciudades aparecen como factores coadyuvantes del descuido de las fortificaciones ${ }^{435}$. Más bien habría que pensar que la incapacidad para movilizar mano de obra limitó tanto las posibilidades de las autoridades urbanas de mantener unas defensas adecuadas como la capacidad de los ejércitos de poner en práctica sistemas de asalto más complejos, aunque en el fondo la contracción económica del periodo había convertido a las

${ }^{433}$ Greg. Tur., Hist., 2.32 ("Auctis adhuc Chlodovechus rex viribus post Gundobadum abiit, ut eum de civitate extractum interemeret. Quod ille audiens, pavore perterritus, metuebat, ne ei mors repentina succederet. Habebat tamen secum virum inlustrem Aredium, strinuum atque sapientem, quem ad se arcessitum, ait: 'Vallant me undique angustiae, et quid faciam ignoro, quia venerunt hi barbari super nos, ut, nobis interemptis, regionem totam evertant'. Ad haec Aredius ait: 'Oportit te lenire feritatem hominis huius, ne pereas. Nunc ergo, si placit in oculis tuis, ego a te fugire et ad eum transire consimulo, cumque ad eum accessero, ego faciam, ut neque te neque hanc noceant regionem. Tantum ut quod tibi per meum consilium demandaverit implere studias, donec causam tuam Dominus prosperam facere sua pietate dignetur'. Et ille: 'Faciam', inquid, 'quaecumque mandaveris'. Haec eo dicente, vale dicens Aredius discessit, et ad Chlodovechum regem abiens, ait: 'Ecce! Ego humilis tuos, piissime rex, ad tuam potentiam venio, relinquens illum miserrimum Gundobadum. Quod si me pietas tua recipere dignatur, integrum in me famulum atque fidelem et tu et posteri tui habebitis'. Quem ille prumptissime colligens secum retinuit. Erat enim iocundus in fabulis, strinuus in consiliis, iustus in iuditiis et in conmisso fidelis. Denique Chlodovecho cum omni exercito circa murus urbis resedente, ait Aredius: 'Si dignanter, o rex, gloria celsitudinis tuae paucos humilitatis meae sermones vellit accepere, consilium licet non egeatis, tamen fide integra ministrabam; idemque vel tibi congruum vel civitatibus erat, per quas transire diliberas. Cur', inquid, 'retines exercitum, cum loco firmissimo tuus resedeat inimicus? Depopularis agros, prata depascis, vineas dissecas, olivita succidis omnesque regiones fructus evertis; interim et ille nocere nihil praevalis. Mitte potius legationem et tributum, quod tibi annis singulis dissolvat, inpone, ut et regio salva sit et tu tributa dissolventi perpetuo domineris. Quod si noluerit, tunc quod libuerit facies'. Quo consilio rex accepto hostem patriae redire iubet ad propria. Tunc missa legationem ad Gundobadum, ut ei per singulos annos tributa inposita reddere debeat, iubet. Ad ille et de praesenti solvit et deinceps solviturum se esse promittit"); Av., Ep., 50 ("Verum tamen peculiarem sibi mercedem suam sermo meus fuerat vindicaturus recolens utique tempus illud, quo inter saevissimas perturbationum procellas confecti operis firmam soliditatem quasi gubernatores invicti ad de dicationis portum, circumstridentibus undique naufragiorum casibus, impune duxistis, me, ut ex communi necessitate recolitis, pro gaudiis lacrimas dependente: cui tum ipsum praematurae invocationis ardore, causarum actione librata, non minus congerere suadeo, quam plangere: quia non ut nuptae tali sponso, cui pacta fuerat, qualiter cumque iungendae, etsi satis desiderabantur strumenta cultuum, plus tamen formidari oportuit tela raptorum").

${ }^{434} \mathrm{La}$ matanza y la esclavización de los habitantes de las ciudades parecen haber sido prácticas más comunes en la parte oriental del imperio romano durante la antigüedad tardía (Lee 2007, 133-138).

${ }^{435}$ Halsall 2003, cap. 10. 
ciudades en pálidos reflejos de lo que otrora fueran, perdiendo de esta forma atractivo para quienes buscaban botín ${ }^{436}$. Quizás por ello resultara de mayor interés saquear los campos a la espera de una decisión del enemigo.

A. D. Lee ha advertido que cuando se daban conflictos bélicos reiterados o cuando la guerra coincidía con alguna catástrofe natural o con el brote de una enfermedad, se hacía difícil para las regiones afectadas recuperarse de los estragos ${ }^{437}$. Incluso el mero paso de un ejército podía producir grandes daños en las producciones rurales, como ocurrió durante el viaje de la comitiva de Rigunta desde París a Toledo. El obispo compara el hecho en cuestión con un desastre natural ${ }^{438}$. Otros pasajes de su obra plantean escenarios similares ${ }^{439}$. Su exageración no desmiente una realidad efectiva, pues cuando se terminaban los suministros los ejércitos en campaña se dedicaban a las requisiciones más o menos legales o al saqueo llano ${ }^{440}$. Debe tenerse en cuenta que el mantenimiento de los soldados demandaba enormes cantidades de víveres $^{441}$. Finalmente, parece que el mantenimiento de la disciplina en los ejércitos fue una tarea particularmente difícil de lograr en el periodo analizado ${ }^{442}$.

A la hora de evaluar el impacto económico de la guerra, es necesario atender asimismo a lo señalado anteriormente en cuanto al pillaje al que se dedicaban las bandas armadas durante los interludios "pacíficos". Cesáreo de Arlés pone de relieve el peligro

\footnotetext{
${ }^{436}$ Liebeschuetz (2001) defiende la idea de fuerte contracción urbana desde el bajo imperio, con referencias al caso galo. Guyon (2001) analiza en particular las transformaciones de las ciudades en la Galia durante los siglos IV-V; especialmente en las pp. 574-576 se pone en evidencia el empobrecimiento del estilo de vida aristocrático, aunque el autor prefiere hablar de "mutaciones" en lugar de contracción. Véase también el número 63 de la revista Gallia, dedicada a la ciudad gala meridional entre los siglos III y VII.

${ }^{437}$ Lee 2007, 117. Téngase en cuenta, por otro lado, que en 541 comenzó una pandemia que se desplegó desde Constantinopla a través del Mediterráneo. Gregorio de Tours da cuenta de su impacto en la Galia en Glor. Mart., 50 ("Galli episcopi oratione depulsa est, et in súbita contemplatione parietes domorum atque eclesiarum signarentur atque caraxarentur"); V. Pat., 6.6 e Hist., 4.5. Se refiere a posteriores brotes epidémicos y plagas en Hist, 4.16, 4.31-32, 5.34, 6.14-15, 6.33, 6.44, 7.1, 8.39, 9.13, 9.20-22, 10.1, 10.23 y 10.30 .

${ }^{438}$ Greg. Tur., Hist., 6.45: "Denique haec de Parisius progressa, octavo ab urbe miliario tenturia figi praecepit. Surgentes enim quinquaginta viri de nocte, ad prae hensis centum equitibus optimis totidemque frenis aureis ac duobus catenis magnis, ad Childeberthum regem fuga dilapsi abierunt. Sed et per totum iter cum labi quis potuisset, effugiebat, ferens secum quae arripere potuisset. Apparatus quoque magnus expense de diversis civitatibus in itenere congregatus est; in quo nihil de fisco suo rex dare praecepit, nisi omnia de pauperum coniectures [...] Per quam via tanta spolia tantaequae praedae factae sunt, ut vix valeant enarrare. Nam hospiciola pauperum spoliabant, vineas devastabant, ita ut incisis codicibus cum uvis auferrent, levantes pecora vel quicquid invenire potuissent, nihil per viam quam gradiebantur relinquentes").

${ }^{439}$ Greg. Tur., Hist., 7.24, 7.35, 8.30 y 10.3

${ }^{440}$ Halsall 2003, 126-128. Sobre el efecto de las guerras en el área rural véase también Lee 2007, 138141.

${ }^{441}$ Véase el capítulo 1.

${ }^{442}$ Halsall 2003, 152.
} 
real de la esterilidad de los campos en un sermón en el que compara la perdición del alma con el saqueo y la desidia de $\operatorname{los}$ cultivos $^{443}$. Varios pasajes del Decem libri historiarum indican que el tránsito de los civiles por los caminos a menudo resultaba inseguro $^{444}$, hecho que lógicamente debió de perjudicar el flujo de los intercambios, aun cuando la contracción del comercio obedeciera principalmente a la incapacidad de las aristocracias de sostener un consumo distintivo ${ }^{445}$.

Sin embargo, esto no debe llevar a confundir las realidades socioeconómicas de las regiones al norte y al sur del Loira. Aunque no sea objeto de nuestro particular interés, es importante señalar que la desestructuración de la sociedad tradicional en Galia septentrional fue muy anterior a la meridional. La mayoría de los autores coinciden en señalar los años 350-400 como el periodo de su inicio, de modo que el impacto de los procesos que estamos describiendo se produjo sobre un escenario relativamente distinto en el norte y en el sur ${ }^{446}$.

\footnotetext{
443 Caes., Serm., 6.6: "Praecidis de vite tua quod malum est: incide de anima tua quod iniquum est. Quomodo qui vitem suam uno anno putare noluerit, ipso anno abundantius exhibet, et postea sine fructu sterilis remanebit; sic et qui malas cogitationes et mala desideria non tollit de anima sua, videtur afferre fructum de rapinis et fraudibus in anno vitae suae quo vivit in hoc mundo, sed postea remanebit sterilis in aeternum".

${ }^{444}$ Greg. Tur., 5.25, 6.11, 6.45 y 9.32. Véase también Doehaerd 1974, 177-179.

445 Véase el capítulo 6.

446 Wickham 2003; 2005, 794-803; Devroey 2003, 28-31 y 37; Van Ossel 2010. Wickham parece exagerar la prontitud de la recuperación del norte de la Galia (ya en el siglo VI).
} 


\section{4 \\ EL SISTEMA FISCAL}

En este capítulo se analiza el sistema fiscal en el periodo c. 400-c. 550. La descripción de la estructura administrativa bajo imperial con que se inicia deberá, no obstante, retrotraerse a los tiempos de Diocleciano, cuando se fijaron sus cimientos. El desarrollo posterior estará por supuesto enfocado en el caso de la Galia meridional, aunque referencias a otras regiones aparecerán conforme la ocasión lo amerite. El interés estará centrado en analizar, en primer lugar, el impacto que tuvo la presión físcal sobre los contribuyentes -en especial sobre los campesinos- y cómo estos reaccionaron a la misma luego de las invasiones germánicas y, en segundo lugar, la crisis del sistema en occidente y la incapacidad de los reinos sucesores de mantenerlo en funcionamiento.

Una cuestión conceptual a destacar es la de la diferenciación entre impuestos y tributos. Chris Wickham ha planteado que los últimos podrían ser entendidos como sumas debidas por comunidades o individuos a terceros en el marco de relaciones de dominación por las armas. La mayoría de las veces son arbitrarios e irregulares en su incidencia. Por el contrario, los sistemas fiscales se basan en evaluaciones de las riquezas muebles o territoriales de las personas o grupos gravados. De esta manera, los Estados basados en la tributación difícilmente pueden obtener los niveles recaudatorios de los que establecen impuestos, por el simple hecho de que son estos últimos los que saben quiénes son aquellos que tienen recursos para pagar ${ }^{447}$. Esta distinción resulta sumamente sugestiva porque nos invita a no exagerar el carácter arbitrario del sistema

${ }^{447}$ Wickham 2005, 70. 
fiscal. Wickham no pretende dar a entender que los sistemas tardo-romano, bizantino y árabe no entrañaran corrupción, opresión y violencia, sino destacar el hecho de que la explotación se daba en un marco institucional reconocido y relativamente estable ${ }^{448}$. Pero más allá de esto, en la medida en que el problema a tratar será el de la crisis del aparato fiscal tardo-romano, utilizaremos el término "tributo" como sinónimo de "impuesto".

\section{EL APARATO FISCAL TARDO-ROMANO}

El principal propósito de las autoridades imperiales desde el principado fue la obtención y distribución de recursos para el sostenimiento del ejército profesional, encargado de proteger las fronteras y asegurar el orden interno. En este sentido, los gastos militares representaban la mayor partida presupuestaria para el Estado ${ }^{449}$.

Durante el alto imperio, el gobierno central exigía a los habitantes de las ciudades un monto determinado como contribución fiscal anual, dejándoles un margen considerable de autonomía en cuanto a la forma de recaudarlo; quiénes debían contribuir, en qué modo y de acuerdo a qué criterios quedaba librado a la determinación de las autoridades locales ${ }^{450}$. Se pagaba un impuesto a la propiedad (tributum soli) y otro personal (tributum capitis), aunque se desconoce el grado de difusión de este último. Por otro lado, existían a lo ancho del imperio otros gravámenes directos e indirectos, ordinarios y extraordinarios, además de exigencias en corveas y servicios ${ }^{451}$. En general, la política seguida por Roma tras las conquistas consistió en dar continuidad a las exacciones vigentes en las regiones que conocían la explotación pública principalmente en las provincias orientales-y en imponer nuevos principios y prácticas en aquellos lugares que la desconocían o en las que era insatisfactoria -las provincias occidentales, mayormente. Esto tuvo como consecuencia la existencia hasta fines del siglo III de un sistema fiscal con un impacto geográfico muy desigual en el que, por otra

\footnotetext{
${ }^{448}$ Wickham 2005, 72.

${ }^{449}$ E. g. Rathbone 1996.

${ }^{450}$ Goffart 1974, 9-11 y 14-21. De cualquier modo, el grueso de la carga caía con seguridad sobre los sectores inferiores (Hopkins 1980, 121).

${ }^{451}$ Corbier 2005, 367-370; Cerati 1975, 5-6.
} 
parte, las provincias más ricas -en particular África y Asia- eran las que más contribuían $^{452}$.

Diocleciano sentó los fundamentos de lo que sería el aparato fiscal durante todo el periodo tardo-romano al sistematizar y regularizar esas exacciones convirtiéndolas en un impuesto general sobre la tierra y la población rural ${ }^{453}$. La administración de los ingresos imperiales se dividió en tres departamentos independientes, cada uno con sus propios ingresos, tesoro y personal administrativo: el de los prefectos del pretorio, el de las sacrae largitiones y el de la res privata ${ }^{454}$. El prefecto pretoriano se convirtió en el principal recaudador, de modo que el análisis se centrará en su figura luego de repasar someramente la de los otros dos ${ }^{455}$.

Por último, debe señalarse que la fragmentación definitiva del imperio en dos mitades tras la muerte de Teodosio I no supuso una solución de continuidad en el orden administrativo. Solo los cargos burocráticos centrales se vieron alterados con la necesidad de crear una corte para oriente y otra para occidente. Por lo demás, el gobierno de ciudades, provincias, diócesis y prefecturas continuó por los carriles heredados ${ }^{456}$.

\section{$L a$ res privata}

La res privata estaba formada en principio por el conjunto de propiedades de quienes habían accedido a la púrpura. Estos bienes habían sido legados por familiares, parientes y amigos de los emperadores, confiscados a criminales y adquiridos a partir de sucesiones intestadas. Además, lo que quedaba de ager publicus había sido absorbido por la res privata durante el principado. De esta forma, para fines del siglo III, y como resultado de siglos de acumulación de propiedades, la extensión de tierras

\footnotetext{
${ }^{452}$ Corbier 2005, 362-363.

${ }^{453} \mathrm{La}$ reestructuración del aparato fiscal por parte de Diocleciano se engloba dentro de toda una serie de reformas impulsadas durante su gobierno. De acuerdo a la cronología establecida por Jean-Michel Carrié y Aline Rousselle (1999, 192), entre el año 287 y el 300 se impulsaron: la reforma fiscal (año 287), la reforma monetaria (año 296), la creación de las diócesis (año 297) y la institución de las requisiciones de metales preciosos (año 300). Para Durliat (1990, 14-15), la gran reforma de este emperador consistió en una revisión general de los catastros y de las declaraciones individuales relativas al impuesto personal. Se levantaron registros llamados libri censuales, descriptiones y polyptici donde se inscribían los contribuyentes con el montante de impuesto que debía cada uno.

${ }^{454}$ Estas dos últimas denominaciones aparecen durante el reinado de Constantino, aunque las atribuciones de los cargos fueron fijadas con Diocleciano (Carrié y Rousselle 1999, 588-589).

${ }_{455}$ Jones 1964, 411-412; Barnish, Lee y Whitby 2000, 194-195.

${ }^{456}$ Sobre la burocracia imperial de los años 337 a 425, véase Kelly 1998. Para el periodo posterior al primer cuarto del siglo V, consúltese Barnish, Lee y Whitby 2000.
} 
pertenecientes al Estado era muy vasta y de carácter muy disperso. La evolución posterior fue fluctuante, pero al parecer los bienes bajo control del departamento fueron de una cuantía sustancial hasta finales del imperio ${ }^{457}$.

La autoridad máxima a cargo de la gestión de este patrimonio fue, a partir del gobierno de Constantino, el comes rei privatae. Debajo suyo había una organización que contaba con cinco subdepartamentos en la corte imperial, administradores a nivel de las diócesis y las provincias y funcionarios a cargo de las propiedades imperiales. La principal tarea del departamento era la administración y recolección de las rentas de dichas propiedades; pero también era de su incumbencia incorporar y reclamar tierras para el Estado y eventualmente donarlas o venderlas ${ }^{458}$.

Por lo general, sin embargo, las tierras de la res privata se daban en arriendo a grandes contratistas (conductores). La mayoría de los acuerdos estipulados entre estos y el Estado era de tenencia a perpetuidad o en enfiteusis, que en un principio eran diferentes, pero que hacia fines del siglo IV se habían vuelto equivalentes en lo concerniente a estas tierras en particular. Además de una renta anual, los contratistas debían pagar a las autoridades imperiales el impuesto territorial, aunque como compensación estaban excluidos de las contribuciones extraordinarias ${ }^{459}$. Pero a diferencia de lo que ocurría con los departamentos del comes sacrarum largitionum y de los prefectos del pretorio, que tenían asignadas partidas específicas, los ingresos provenientes de la res privata parecen haber estado a disposición de los emperadores para ser utilizados discrecionalmente, particularmente como regalos en la construcción de vínculos políticos ${ }^{460}$.

Durante la época merovingia en la Galia, los reyes también buscaron explotar los dominios fiscales que eran herencia remota de la res privata, pero la necesidad de renovar constantemente el apoyo político de la aristocracia -que como hemos visto en el capítulo previo caracterizó a la monarquía franca- exacerbó la entrega de tierras. Incapaces de cortar la hemorragia, los sucesivos reyes se vieron obligados a incrementar constantemente las propiedades fiscales a través de la guerra ${ }^{461}$.

\footnotetext{
${ }^{457}$ Jones 1964, 414-416 y 420-424. Sabemos por una ley de 422 que la sexta parte de las tierras de la provincia africana de Proconsular pertenecía al emperador (C. Th., 11.26.13; Corbier 2005, 386-387).

${ }_{458}$ Barnish, Lee y Whitby 2000, 171; Jones 1964, 412; Durliat 1990, 35-36.

${ }^{459}$ Whittaker y Garnsey 1998, 283-284; Jones 1964, 416-420.

${ }^{460}$ Jones 1964, 424-426; Corbier 2005, 362.

${ }^{461}$ Devroey 2003, 245-247.
} 


\section{Las sacrae largitiones}

El comes sacrarum largitionum estaba a la cabeza de un elaborado departamento que controlaba las cecas, las minas de oro (y probablemente también las de plata) y los talleres estatales donde se decoraban con metales preciosos las armas y las armaduras. Entre sus responsabilidades se encontraban la de hacer donativos regulares en oro y plata y, realizar ciertos pagos en dinero a soldados y oficiales; además se encargaba de distribuir la producción de vestimenta entre los miembros de la corte, el ejército y la administración civil.

El departamento administraba una serie de impuestos -algunos viejos y otros instituidos por Constantino- que se pagaban en oro y en plata. Recibía derechos sobre exportaciones, importaciones y tránsito interno de productos; percibía el aurum coronarium, que las ciudades otorgaban al emperador en ocasión de su acceso al poder, cada quinto aniversario y en ocasiones de festejos especiales y el aurum oblaticium, ofrecido en las mismas ocasiones por el senado. El monto de estos dos últimos impuestos se libraba a la voluntad de los contribuyentes, aunque el Estado no ahorraba en sugerencias. También recaudaba el aurum tironicum -un gravamen a la conmutación de la leva- y un impuesto a la tierra muy menor en relación al que percibían los prefectos del pretorio ${ }^{462}$.

Dos impuestos instituidos por Constantino merecen especial atención: la collatio glebalis o follis, de carácter anual, y la collatio lustralis, recaudada cada cinco años contando desde la asunción del emperador. La primera se cobraba exclusivamente a los senadores, en base a una declaración completa de sus bienes, y se destinaba a los senados de Roma y Constantinopla. Se desconoce la magnitud a la que ascendía, pero, según Durliat, debió de ser considerable. Por su parte, la collatio lustralis recaía sobre los negotiatores, es decir, sobre todos aquellos que vivían del comercio o del cobro de honorarios, con exclusión de médicos y profesores, los terratenientes y campesinos que vendían sus propios productos y, desde 374 , los artesanos rurales ${ }^{463}$.

Finalmente, cabe mencionar la capitatio plebeia, una fórmula que aparece en cuatro disposiciones emitidas entre 343 y 370 dirigidas al prefecto de las Galias ${ }^{464}$. Según Goffart, no se trataría de un impuesto personal, como se ha sostenido

\footnotetext{
${ }^{462}$ Barnish, Lee y Whitby 2000, 171-172; Jones 1964, 427-437; Durliat 1990, 33-35.

${ }^{463}$ Durliat 1990, 31-33; Jones 1964, 431-432.

${ }^{464}$ C. Th., 12.1.36 (año 343), 11.21.2 (año 362), 13.10 .4 (año 368) y 13.10.6 (año 370).
} 
comúnmente, sino de una responsabilidad fiscal que, como la collatio glebalis o la collatio lustralis, afectaban a un grupo social en particular (aunque no queda claro para Jones que se tratase de la plebe urbana) ${ }^{465}$.

\section{Los prefectos del pretorio}

El departamento fiscal más importante era el de los prefectos del pretorio. En cierto modo, estos funcionarios eran una réplica a escala menor de los emperadores pues tenían atribuciones judiciales y derecho a sancionar edictos; la dignidad conferida al cargo era altísima ${ }^{466}$. Eran además los responsables de la annona, destinada tanto al mantenimiento del ejército y la administración civil como al suministro de grano para alimento de las dos capitales y algunas de las más importantes ciudades del imperio ${ }^{467}$.

Antes de proseguir con la descripción de las facultades de estos funcionarios, es necesario realizar algunas puntualizaciones con respecto al significado del término "annona" y su relación con el aparato fiscal tardo-romano. Durante mucho tiempo se consideró la annona como un suplemento o una pequeña parte del gravamen territorial, aquella evaluada y pagada en especie para mantenimiento del ejército. Posteriormente, se corrigió esta interpretación para sostener que en realidad la res annonaria, entendida como prestaciones en especie, habían constituido lo esencial del impuesto a la tierra durante el bajo imperio. Por otro lado, existió además una tendencia a considerar la annona militaris en sí como un impuesto, porque la "forma annonaria" (en palabras de André Cerati) que el gravamen a la tierra adoptó en el bajo Imperio -es decir, su conmutación en especie- estuvo estrechamente ligada a las necesidades de la organización militar y sufrió sus vicisitudes. Este historiador clarificó el problema hace ya tiempo, diferenciando el concepto de "fiscalidad annonaria", entendida como la parte del impuesto a la tierra que era percibida en especie, y el de "annona militaris", el abastecimiento del ejército ${ }^{468}$.

Los prefectos eran, entonces, los encargados de calcular cada año el monto total a recaudar en función de los gastos que se debían afrontar. Tradicionalmente se pensó que a partir del siglo IV -e incluso desde antes, dada la inflación de la centuria previa-

\footnotetext{
${ }^{465}$ Goffart 1974, 37-38; Jones 1957, 92.

${ }^{466}$ Barnish, Lee y Whitby 2000, 174; Kelly 1998, 166. No obstante, los prefectos del pretorio perdieron sus atribuciones militares a manos de Constantino.

467 Jones 1964, 448.

${ }^{468}$ Cerati 1975, 11-12, 104 y 150-151; Carrié y Rousselle 1999, 589-591.
} 
se había universalizado el cobro de los tributos en especie. Cerati sostuvo que la reintroducción del pago en metálico comenzó a darse solo a partir de c. $380^{469}$. Sin embargo, Jean-Michel Carrié y Aline Rousselle han planteado más recientemente que las políticas imperiales estuvieron dominadas por un pragmatismo que se tradujo en una recaudación ajustada de la forma más conveniente a las particularidades de cada región. El imperio no tenía interés alguno, por ejemplo, en cobrar sus impuestos en productos en las zonas alejadas de las guarniciones o del transporte fluvial y marítimo. No obstante, es cierto que con la Tetrarquía la recaudación en especie alcanzó el punto máximo y que el pago en oro se expandió desde fines del siglo $\mathrm{IV}^{470}$.

Los prefectos recibían anualmente informes de los magistri militum y de los duces sobre las unidades militares bajo su mando y de los officia sobre las necesidades de la administración civil. Los requerimientos del cursus publicus y de las capitales, en cambio, parece que eran más estables y consecuentemente predecibles sobre la base de cálculos anteriores. Con esta información en su haber, estimaban el nivel anual de tributación necesaria para afrontar los gastos de sus jurisdicciones; si las cuentas no cerraban, debía recurrirse a exacciones extraordinarias ${ }^{471}$.

El monto total requerido por cada prefectura se dividía en unidades fiscales uniformes. Todas las tierras agrícolas, cualquiera fuera su uso o calidad, fueron valuadas durante el gobierno de Diocleciano en unidades llamadas generalmente “iuga" ${ }^{472}$. Así, por ejemplo, de acuerdo al Libro de derecho sirio-romano, en las tierras de Siria un iugum equivalía a cinco yugadas de viñedos, veinte de tierra arable, etc. Durliat estima que en la Galia el valor del iugum se mantuvo más o menos constante a lo largo del periodo bajo imperial, entre 8 y 12 ha. de tierra arable. De esta manera, la cantidad de iuga que cada contribuyente debía por el total de sus propiedades era constante, mientras que lo que variaba anualmente -en función de las necesidades recaudatorias del Estado- era el monto del iugum como unidad ${ }^{473}$.

Por otro lado, existe una larga discusión historiográfica sobre el significado de "caput" desde un punto de vista fiscal. Son muchas las interpretaciones que han sido dadas desde el siglo XIX, pero básicamente pueden dividirse en dos grupos: aquellas

\footnotetext{
${ }^{469}$ Cerati 1975, 57-101; Lee 2007, 403-407.

${ }^{470}$ Carrié y Rousselle 1999, 591-592; Barnish, Lee y Whitby 2000, 194.

${ }^{471}$ Jones 1964, 451-452. Con respecto a las exacciones extraordinarias, existían categorías privilegiadas de personas como los contratistas de tierras imperiales, los senadores y la Iglesia, inmunes a estos pagos.

${ }_{472}$ Centuria en África y millena en Italia.

${ }^{473}$ Durliat 1990, 16-19; Goffart 1974, 33-34; Jones 1964, 453.
} 
englobadas en una concepción "unitaria" del sistema fiscal, que interpretaban (e. g. Ferdinand Lot) el caput como una unidad de asignación equivalente al iugum, independiente de la existencia o no de un tributo personal, y las teorías "bivalentes", aquellas que defendían (e.g. Jones) la presencia de dos formas distintas de evaluar el impuesto, una concerniente a las tierras y la otra a las personas ${ }^{474}$. André Déléage diferenció regionalmente los sistemas: Galia e Italia habrían estado gravadas según un sistema bivalente, pero no así Egipto, África o Siria. Esta es también, grosso modo, la posición defendida por Carrié y Rousselle. En su opinión, “caput” se refiere tanto a los individuos mismos como a la unidad de repartición que toma la forma de fracción aritmética que se suma a los iuga en las imposiciones mixtas o bivalentes ${ }^{475}$. En la Galia y en las provincias sometidas a la computación "doble" o "combinada", el cálculo del tributo asociaba superficie y población registrada en la tierra. Este sistema se justificaba más en los lugares en que se necesitaba dinero, mientras que donde se necesitaba recaudar productos se prefería el sistema de impuestos separados. No obstante, en regiones fronterizas donde estaba apostado el ejército (el Rin, por ejemplo) podía darse el pago en especie o las requisiciones en vigencia del sistema de computación doble o combinada $^{476}$.

Resulta ocioso continuar indagando en estas discusiones en la medida en que nuestro interés está puesto en la carga que supuso el impuesto para la población rural y no en la forma en la que era cobrado. En suma, alcanza con señalar que todas las propiedades territoriales, tanto las pequeñas como las grandes, estaban gravadas con una cantidad determinada de capita por las personas allí registradas (el titular, la familia, los esclavos, los coloni adscripti) y de iuga. El monto anual total que cada dominio debía pagar en concepto de las distintas unidades fiscales se establecía, como hemos dicho, en función de las necesidades presupuestarias fijadas por el prefecto del pretorio. La operación consistía en dividir esa cifra total entre las distintas jurisdicciones que mediaban entre la prefectura y las propiedades individuales (diócesis, provincias, ciudades) ${ }^{477}$.

\footnotetext{
${ }^{474}$ Cerati 1975, 192-332.

475 En este sentido, los 7000 capita condonados por el emperador a Autun según el Pan. Lat. 5(8) obedecerían a una revisión del censo. Para Corbier (2005, 378-379), en cambio, el caput podría ser una unidad constante, usada para calcular el impuesto a pagar por las ciudades colectivamente y luego, dentro de cada una, por los individuos residentes, teniendo en cuenta tanto el número de individuos como su riqueza.

${ }_{476}$ Carrié y Rousselle 1999, 598-604.

477 Jones 1964, 454.
} 
Puesto que el iugum era una unidad constante establecida en relación a los atributos del suelo tasado, los cuales podían alterarse en función de desastres naturales o de la acción del hombre, debería de haberse establecido la práctica de revisar frecuentemente el censo a fin de evitar injusticias en la asignación de las cargas fiscales. Hemos analizado en los capítulos anteriores los efectos que sobre los campos tuvo la guerra en términos generales. No obstante, solo hubo revisiones aisladas de catastros de ciertas jurisdicciones o de particulares que lo requirieron puntualmente. Por otro lado, en la mayoría de los casos en que se reclamaba que determinadas tierras habían dejado de ser cultivadas, la política imperial fue la de redistribuir las cargas de esos dominios entre los propietarios vecinos. En cuanto a la capitatio, el mantenimiento de los censos originales tenía como consecuencia que las distintas jurisdicciones fiscales (aldeas, propiedades) pagaban una cantidad determinada más allá de las fluctuaciones poblacionales en su interior ${ }^{478}$.

\section{Los curiales}

Ahora bien, dentro del encadenamiento de instancias burocráticas que iba de los contribuyentes al prefecto del pretorio, el curial -o decurio- ocupaba un lugar destacado como responsable del monto total de la carga fiscal de su civitas ante las instancias superiores ${ }^{479}$. El sistema por el cual la curia (colectivamente) y los curiales (individualmente) eran responsables del pago de los impuestos se estableció en el alto imperio $^{480}$ y continuó durante el periodo tardo-romano ${ }^{481}$. Sin embargo, el poder de los curiales fue decayendo progresivamente en las ciudades a partir del siglo IV, más lentamente en occidente que en oriente, siendo reemplazado por la autoridad más bien de facto de notables y obispos ${ }^{482}$.

\footnotetext{
${ }^{478}$ Durliat 1990, 16; Jones 1964, 454-455.

479 Entre este y el prefecto del pretorio, la recaudación pasaba por los vicarios y los gobernadores provinciales. Anualmente se enviaba personal del gobierno central a cada provincia para la supervisión de las actividades fiscales (Jones 1964, 450).

${ }^{480}$ La práctica anterior era el arrendamiento del cobro de tributos a compañías de publicanos (Nicolet 1976).

${ }^{481}$ Corbier 2005, 371-372. Durliat (1990, 64-71) tiene una visión completamente diferente. En su opinión, el cobro de los impuestos estaba a cargo de los más ricos en régimen de arrendamiento. La tarea de los funcionarios públicos en este universo sería la de controlar. Profundizaremos más adelante la visión de Durliat sobre el funcionamiento del sistema fiscal.

${ }^{482}$ Liebeschuetz 2001, 104-136.
} 
Teniendo en cuenta las obligaciones a las que estos funcionarios estaban sometidos podría parecer que la recolección de los impuestos fue una tarea impopular durante el bajo imperio. Así lo sugirieron muchos historiadores en el pasado, entre los que puede destacarse a Rostovtzeff ${ }^{483}$. Pero lo cierto es que el sistema no estaba a salvo de que los funcionarios encargados de percibir las cargas públicas en las ciudades cometieran injusticias, subvirtiendo lo indicado en los registros catastrales. Lamentablemente, no tenemos ningún periodo para el cual sepamos cómo eran aplicadas las declaraciones del censo por los curiales al dividir el impuesto y calcular la parte correspondiente a cada ciudadano ${ }^{484}$. Claude Lepelley ha señalado que mientras que Libanio caracterizó al curial como una víctima del aparato fiscal de su tiempo, otros autores como Salviano o -menos exageradamente- Temistio, denunciaron su tiranía ${ }^{485}$. Una y otra vez, las autoridades imperiales promulgaron leyes tendientes a castigar a estos funcionarios municipales que se enriquecían a costa de sus conciudadanos ${ }^{486}$. El problema aparece en todas las provincias en el transcurso del bajo imperio y la reiteración de las disposiciones demuestra en opinión de Lepelley la ineficacia del gobierno para torcer estos comportamientos ${ }^{487}$.

En este sentido, algunos historiadores han considerado que la huida de los curiales, que fue condenada y perseguida por la legislación, tuvo más que ver con su incorporación en la burocracia central o en la Iglesia que con problemas derivados de la imposibilidad de hacer frente a las obligaciones fiscales ${ }^{488}$. Así, una disposición enviada al vicario de oriente en 325 imponía penas a los curiales que se escondieran o se mudaran a otra ciudad ${ }^{489}$. Ciertamente, la interpretación de la ley según el argumento precedente no resulta incoherente, pero bien podría haberse aplicado en otros lugares a la persecución de funcionarios municipales que evadían cargas que no querían o no podían soportar. La disposición en cuestión fue seleccionada entre otras similares en la recopilación legal hecha durante el reinado de Alarico II en la Galia visigoda, en un

\footnotetext{
${ }^{483}$ Rostovtzeff [1926], 468-475; Jones 1964, 737-763; de Ste. Croix 1988, 542-552.

${ }^{484}$ Corbier 2005, 372 .

${ }^{485}$ Temistio y Libanio fueron relativamente contemporáneos. Ambos vivieron entre comienzos y fines del siglo IV en la pars orientis.

${ }^{486}$ C. Th., 11.6.3-4 (año 324), 12.6.22 (año 386) y 11.7.20 (año 412).

${ }^{487}$ Se llegó incluso a decretar que los curiales podían ser torturados (C. Th., 8.2.4, año 384).

488 Cameron 1998, 104-105; Liebeschuetz 2000, 208. Véase la enorme cantidad de disposiciones agrupadas en $C$. Th., 12.1 bajo el título De decurionibus.

${ }^{489}$ C. Th., 12.1.12.
} 
periodo y un reino en el que muy probablemente el aparato fiscal se hallara en crisis ${ }^{490}$. Otra orden imperial, enviada en este caso al prefecto del pretorio de las Galias en 409 o 412, recordaba que los curiales debían servir en sus municipalidades por un periodo de quince años, pero aconsejaba tener una política moderada con aquellos que habían huido, obligando a regresar a sus funciones solo a quienes lo habían hecho en los últimos seis años ${ }^{491}$. Si el problema de las fugas no era nuevo, parece que se intensificó desde fines del siglo $\mathrm{IV}^{492}$. Por otro lado, si bien las disposiciones que versan sobre curiales evasores conciernen a ambas partes del imperio, al menos hasta el primer cuarto del siglo $\mathrm{V}$ son más abundantes dentro de las emitidas para occidente las que tienen un contenido preventivo sobre qué hacer ante la fuga. Pareciera como si se hubiese llegado a un punto tal en el que había dejado de tener sentido la persecución de estos desertores para pasar a tener prioridad el establecimiento de una suerte de casuística ante los hechos consumados, a la vez que se intentaba proteger a estos miembros del senado local de terceros como potentes y funcionarios con tendencias autonomistas $^{493}$. En 450 se reinstauró una serie de disposiciones tendientes a asegurar que aquellos curiales que se habían refugiado en el estamento eclesiástico traspasaran cada uno a un sustituto sus antiguas obligaciones cívicas y se desprendieran de parte de su patrimonio en favor de sus hijos, sus parientes o el municipio ${ }^{494}$; asimismo, prohibía el ingreso al clero a quienes no hubiesen cumplido con los años de servicio debido. Pese al tono exagerado, resultan de mucho interés las palabras de los emperadores Teodosio II y Valentiniano III en el prefacio de la ley en cuestión, pues revelan que los pocos hombres que quedaban al frente del servicio municipal no podían sobrellevar la carga y que el traspaso de tierras a manos de personas que no estaban sometidas a las

\footnotetext{
${ }^{490}$ Liebeschuetz 2001, 128.

491 C. Th., 1.12.171. La morigeración de las penas estipuladas con respecto a estos fugitivi fue in crescendo. El plazo de regreso a la curia pasó de ser de cinco días en 395 (C. Th., 12.1.143), a un año en 399 (C. Th., 12.1.161). En el año 416 (C. Th., 12.1.181) se menciona la posibilidad de que los desertores nombraran suplentes que cumplieran con sus obligaciones. En 423 (C. Th., 8.4.28, enviada a oriente) se admite que habiendo cumplido diez años de servicio, un curial que se hubiese refugiado en el ejército podía considerarse libre de la carga; la ley no mencionaba la necesidad de nombrar un sustituto. Esta evolución jurídica ha sido convincentemente interpretada como una resignación de las autoridades imperiales frente a una realidad que les era esquiva (Jordán Montes 1997, 104).

${ }^{492}$ En el año 395 se decretó que era suficiente reunir las dos terceras partes de las asambleas municipales para nombrar nuevos miembros $(C$. Th., 12.1.142). Tres años más tarde, se permitió el ingreso a los senados de las ciudades a paganos y judíos (C. Th., 12.1.157 y 158). Las medidas revelan que en distintas regiones ya existían problemas para completar las curias.

${ }^{493}$ Véanse las referencias en Jordán Montes 1997 y especialmente sus comentarios en pp. 121 y 126.

${ }^{494}$ Evidentemente en este punto se buscaba evitar la pérdida de tierras que tributaban al fisco, como se revela en C. Th., 9.45.3 (año 398).
} 
obligaciones propias de los curiales debilitaba el orden municipal ${ }^{495}$. Debemos tener en cuenta que el contexto de esas disposiciones es el de la pérdida del dominio imperial en África. Finalmente, una ley de Mayoriano de 458 pone de relieve que los curiales estaban huyendo de las ciudades para refugiarse en propiedades rurales de terceros y buscando el patronazgo de los ricos a través de uniones con coloni y esclavas (algo impropio de una elite). Además, la norma reitera que en adelante no sería tolerada la alienación de tierras por parte de quienes debían servir en el municipio ${ }^{496}$. En suma, resulta difícil pensar que en el contexto de un gobierno exigido a incrementar la presión fiscal para poder afrontar múltiples amenazas militares, las fugas referidas estuvieran relacionadas con el camino ascendente de las aristocracias locales.

No obstante, en opinión de Lepelley, la mayoría de las veces las víctimas eran los administrados y no los decuriones ${ }^{497}$. El razonamiento probablemente valga para el periodo y las regiones en las cuales el sistema fiscal funcionó más o menos adecuadamente, puesto que es difícil pensar que un sistema que condenara a sus agentes fiscales a la ruina económica pudiese haber sobrevivido aproximadamente tres siglos en oriente y más de un siglo en buena parte de occidente. Sin embargo, cuando la presión del gobierno por acceder a más recursos se hizo fuerte y/o la rebeldía de los contribuyentes comenzó a acrecentarse la posición del curial comenzó a ser más inestable. Ambas cosas ocurrieron en occidente a partir del siglo V; en la Galia meridional con toda seguridad desde c. 440.

\section{EL PESO DEL IMPUESTO}

\section{La magnitud global de los impuestos hasta c. 400}

\footnotetext{
${ }^{495}$ Nov. Val., 3.1: "In augendo statu urbium singularum, servata catholicae religionis veneratione, tam praecendentia veterum parentumque nostrorum statuta renovamus, quae nostris legibus observanda decernimus, ne passim imminutione municipum, cum numerositas ex abundanti clericatus augentur, publica damna generentur. Non dubium est enim, cum non expletis muniis ad obsequium venerabilis ministerii curialis admittitur, relisum in paucos publicae functionis onus nequaquam posse tolerari, et rursus migrantibus patrimoniis curialium ad personas, quae functionibus municipalibus non tenentur, propriam civitatis nutare substantiam".

${ }^{496}$ Nov. Mai., 7.1. En Nov. Mai., 2 (año 458) el emperador condenaba la recaudación ilegal de impuestos por parte de funcionarios no autorizados, práctica que en su opinión estaba conduciendo a la ruina a propietarios y curiales y dejando las arcas públicas casi vacías. Pareciera que la situación era la de una rebeldía contra las autoridades centrales. Véase infra sobre el problema de la corrupción.

${ }^{497}$ Lepelley 1983, 154.
} 
Comencemos este apartado con una afirmación que puede resultar obvia: la agricultura suponía el grueso del producto total del imperio ${ }^{498}$. Esto tenía su correlato en la procedencia del financiamiento estatal: la parte más importante de los fondos públicos provenía del impuesto territorial ${ }^{499}$. Como hemos visto, los impuestos cobrados por los prefectos del pretorio recaían sobre la tierra y la población rural, mientras que la res privata se alimentaba de las rentas de las tierras imperiales y los ingresos de las sacrae largitiones provenían de gravámenes en oro que eran cobrados principalmente a terratenientes. Únicamente la collatio lustralis, subraya Jones, no era pagada directa o indirectamente por campesinos y solo parte de los donativos a las tropas procedía de tributos directos al comercio y la producción artesanal ${ }^{500}$. Así, prácticamente la totalidad de los gastos públicos - la alimentación y vestimenta del ejército y la administración civil, el mantenimiento del transporte, el sostenimiento de la/s corte/s, el suministro de alimento para las dos capitales, etc.- era sustentado por quienes labraban la tierra.

Interesa ahora examinar aproximadamente qué porcentaje del producto total del imperio se destinaba al pago de obligaciones fiscales. La caracterización del Estado posterior a Diocleciano como una entidad que oprimía a sus súbditos a través del impuesto se remonta muy atrás en el tiempo y tuvo plena aceptación hasta entrada la segunda mitad de la centuria pasada. Como hemos visto en el capítulo 1 de esta tesis doctoral, Jones ubicó esta cuestión en el centro de una explicación sistemática sobre la decadencia y caída del imperio romano. Brevemente, propuso que a partir de fines del siglo III el aumento de las necesidades presupuestarias del Estado se había traducido en un incremento de la presión fiscal que, en la larga duración, había ido generando un círculo vicioso de abandono de las tierras marginales, descenso demográfico y elevación de los impuestos por incapacidad de pago de la base contribuyente. Sin embargo, pocos investigadores sostienen hoy que haya habido una crisis agrícola generalizada en el siglo IV, aunque debe reconocerse que no era esa la opinión mayoritaria cuando Jones escribió su obra ${ }^{501}$.

\footnotetext{
${ }^{498}$ Kehoe 2007, 548. Jones $(1964,465)$ estimó que los ingresos derivados de la agricultura superaban en veinte veces a los de la industria y el comercio durante el bajo imperio. Garnsey y Saller (1991, 61-62 y 71) han criticado este cálculo por estar fundamentado en datos aislados y poco apropiados, pero reconocen que la agricultura "era la fuente del grueso de la riqueza del imperio".

${ }^{499}$ Durliat 1990, 36-37

500 Jones 1964, 464-465,

501 Véase infra.
} 
Un primer jalón en la reconsideración de la imagen que se tenía del aparato fiscal imperial lo constituyó un artículo de Keith Hopkins aparecido en el año 1980 en el que el autor polemizaba con ciertos argumentos centrales de la interpretación sustantivista de la economía imperial propuesta poco antes por Moses I. Finley ${ }^{502}$. Hopkins construyó un modelo explicativo de la economía romana aplicable al periodo 200 a. C.-400 d. C. en el que se proponía que el imperio había constituido una economía unificada gracias, en parte, a que los impuestos y las rentas habían promovido la integración comercial de las regiones que lo conformaban ${ }^{503}$. Nuestro interés se halla especialmente en que en dicho trabajo el autor realizó un cálculo de la proporción del producto bruto imperial que se destinaba al pago de impuestos durante el principado, cuyo resultado arrojó índices sorprendentemente bajos. La operación mediante la cual llegó a esas cifras es relativamente sencilla; partió de las siguientes estimaciones: a) la población imperial en dicho periodo rondó los 60 millones de habitantes; b) la cantidad de alimento, combustible y vestimenta necesaria para la supervivencia de cada uno de ellos equivalía a $250 \mathrm{~kg}$ de trigo al año ${ }^{504}$; c) el promedio de rendimiento de la tierra a nivel imperial era de cuatro veces lo sembrado, lo cual implicaba que un cuarto del total producido debía reservarse para la siembra si se quería volver a cosechar volúmenes similares; d) el precio del modio $(6,55 \mathrm{~kg})$ de trigo promediaba los tres sestercios ${ }^{505}$. Esto significaba, según los cálculos de Hopkins, que la producción anual necesaria para el mantenimiento de la población a un nivel de subsistencia equivalía a 8244 millones de sestercios. Si solo se producía un plus del 10\% con el objetivo de pagar los impuestos (es decir, 824 millones de sestercios), se superaba con creces lo necesario para cubrir la principal partida presupuestaria estatal -el ejército- cuyo mantenimiento costaba al imperio muy probablemente unos 350 millones de sestercios ${ }^{506}$. Pero si se producía por encima del mínimo de subsistencia -lo que efectivamente ocurrió, pues las

\footnotetext{
${ }^{502}$ Finley [1973].

${ }^{503}$ Hopkins 1980. El modelo fue perfeccionado una década y media más tarde en otro artículo (Hopkins [1995]). Es preciso señalar que según este autor, los impuestos durante el alto imperio eran cobrados principalmente en moneda, mientras que la mayor parte de los que se percibían en especie eran cambiados por metálico por los agentes públicos para facilitar su traslado. Por otro lado, para Hopkins la renta también terminaba siendo comercializada por una aristocracia absentista (Hopkins 1980, 104-105; [1995], 225-229).

${ }^{504}$ El autor construye esta cifra basándose en estudios de economistas sobre la ingesta diaria mínima real - no esperada- de la población de países del mundo subdesarrollado contemporáneo (Hopkins [1995], 197, n. 11).

${ }^{505}$ El precio del modio de trigo que emplea el autor es un promedio tomado a partir de la información disponible. Cabe destacar que lo que se pagaba en el mercado fluctuaba enormemente (Hokpins [1995], 199, n. 13). Véase en general Bang 2008.

${ }^{506}$ Hopkins 1980, 117-120.
} 
aristocracias vivían de la explotación de sus dependientes- la relación impuesto/producto imperial se reducía aún más, probablemente a entre 5 y 7/100 507 .

Debe decirse que el cómputo sobre el gasto militar es el único dato sobre el que es posible fiarse; la escasez de información primaria para apoyar el resto de las cifras propuestas es reconocida hasta por el propio autor. No obstante, sus cálculos resultaron convincentes para muchos ${ }^{508}$, en primer lugar porque estaban construidos a partir de estudios anteriores sobre los que existía cierto consenso y en segundo lugar porque Hopkins no utilizó precisamente aquellos números que más le hubieran convenido, los que habrían arrojado resultados aún más favorables a su modelo. Por poner un ejemplo, tomó la relativamente conservadora cifra de 60 millones de habitantes para todo el principado frente a las más arriesgadas que calculan en 120 millones la población hacia finales del siglo I d. C. De haber optado por este último cómputo se habría duplicado la estimación del producto bruto imperial y por lo tanto reducido a la mitad la incidencia del impuesto.

Pero Hopkins había dicho poco del periodo posterior a la crisis del siglo III. El corte cronológico que proponía el título de su artículo resultaba engañoso, porque los cálculos sobre la incidencia del impuesto estaban construidos sobre datos pertinentes para el alto imperio. De todos modos, a partir de su modelo parecía posible afirmar que los gravámenes públicos habían continuado siendo relativamente bajos incluso con posterioridad al incremento del gasto militar que se dio a partir de las reformas de Diocleciano y Constantino.

Esto fue lo que propuso Charles R. Whittaker en un artículo que, es preciso aclararlo, fue publicado el mismo año que el de Hopkins y que por ende no daba cuenta de su modelo. De cualquier forma, las bases argumentales eran similares. Whittaker estimó que la expansión del ejército no había alcanzado siquiera a duplicarse (un cálculo que los investigadores actuales tienden a confirmar ${ }^{509}$ ), mientras que el salario de los soldados probablemente se había reducido ${ }^{510}$. Pero aun si no lo hubiese hecho, lo cierto es que si partimos de las cifras propuestas por Hopkins, tendríamos que para el siglo IV los impuestos no superarían el 15 por ciento del producto imperial. Debe tenerse presente en este punto que buena parte del mundo romano vivió una etapa de

\footnotetext{
${ }^{507}$ Hopkins [1995], 201.

${ }^{508}$ E. g. Carrié y Rousselle 1999, 608; Liebeschuetz 2001, 10.

${ }^{509}$ A. D. Lee $(1998,220)$ calcula que el ejército romano pasó de estar compuesto por entre 350 y 400 mil hombres durante el siglo III a entre 500 o 700 mil en el siglo IV.

${ }^{510}$ Whittaker [1980], 8-9.
} 
relativa prosperidad económica durante esta centuria y que no hay evidencias de marcado descenso demográfico como propusiera Jones en su momento, de modo que las estimaciones de Hopkins concernientes a la producción total se adaptarían al imperio tardío con ajustes relativamente menores ${ }^{511}$.

En una línea similar, Carrié y Rousselle han planteado que no hay razones para pensar que, en la larga duración, la fiscalidad tardo-romana se hubiese convertido en un "infierno", aun cuando resulte difícil identificar quiénes y en qué regiones pudieron haber sido particularmente desfavorecidos en el reparto de las cargas. Retoman a Hopkins para sostener que los gravámenes fueron relativamente bajos también en el siglo IV. Por otro lado, consideran que las denuncias de Lactancio sobre colonos que abandonaban sus campos al ver agotados sus recursos por la enormidad de sus impuestos o las observaciones hechas en el panegírico pronunciado el año 311 en Autun, según las cuales un aligeramiento de las exigencias fiscales revertiría la práctica de limitar los nacimientos que se había adoptado espontáneamente en la Galia en reacción contra los excesos precedentes no serían más que exageraciones que la historiografía tradicional había tomado literalmente ${ }^{512}$.

No obstante, habría que matizar esta posición revisionista. Chris Wickham sostuvo recientemente que hacia el año 400 aproximadamente las cargas fiscales probablemente representaran alrededor de un cuarto del total de la producción, una proporción perfectamente compatible con un funcionamiento relativamente estable del sistema pero aun así elevada ${ }^{513}$. Esta estimación parte de una revaluación de los costos de la administración civil, que suelen minimizarse porque se atiende únicamente al bajo número de funcionarios que formaban parte de la burocracia (unos 24.000 para todo el imperio según Heather ${ }^{514}$ ). Aunque no sepamos bien a cuántos guardias, mensajeros, boyeros públicos, sirvientes de palacio, etc. debía pagarse o alimentarse, parece claro que su mantenimiento debía de representar el desvío de un volumen significativo de recursos del Estado. Wickham ha propuesto que solo la mitad del presupuesto público

\footnotetext{
${ }^{511}$ Whittaker [1976]; Carrié y Rousselle 1999, 513-561.

512 Pan. Lat., 5(8); Carrié y Rousselle 1999, 607-611.

${ }^{513}$ Durliat $(1990,37)$ la calcula en un $20 \%$.

${ }^{514}$ Heather 2000, 438.
} 
anual se destinaba al sostenimiento del ejército, mientras que el resto se asignaba a los gastos de la burocracia civil y al reparto de alimentos en las ciudades ${ }^{515}$.

\section{Evasión fiscal y corrupción}

Por otro lado, es importante dedicar un apartado al estudio de la corrupción y la evasión fiscal en relación con el problema de la presión impositiva. Nos valdremos del análisis de algunas leyes y de los escritos de Amiano Marcelino y de Salviano de Marsella. Estos dos últimos autores deben ser leídos con precaución, habida cuenta del dramatismo con que tiñeron su crítica hacia la manera en que se conducían los asuntos públicos de su tiempo. El cuadro social que presentan resulta exageradamente decadente ${ }^{516}$; la corrupción que ambos denunciaron no llevó al ocaso del Estado como pretendió en algún momento cierta historiografía ${ }^{517}$. No obstante, permiten apreciar la inflexibilidad e injusticia que podía alcanzar el sistema fiscal, perjudicando particularmente a los sectores más vulnerables. Las leyes también encierran cierta dificultad de análisis, toda vez que no nos hablan directamente de cómo era la realidad, sino de cómo el Estado pretendía que fuese. De cualquier forma, su riqueza informativa no debe subestimarse ${ }^{518}$.

Varios pasajes de las Res Gestae de Amiano están dedicados a relatar maniobras de corrupción por parte de altos oficiales civiles y militares -en ocasiones en connivencia con personajes ricos- que consistían en el enriquecimiento personal a

\footnotetext{
${ }^{515}$ Wickham 2005, 66 y 73. Debemos aclarar que su cálculo no refiere específicamente a dicho momento, sino que lo propone como válido para todo el periodo posterior al 400, incluso para el siglo VI en lo que respecta al imperio romano de oriente.

${ }^{516}$ Amiano Marcelino planteaba, por ejemplo, que quienes tenían influencia en la corte de Constancio la utilizaban para enriquecerse a costa de los bienes de sus vecinos (16.8.11-13) y que los amigos y parientes de Valente estaban más preocupados por sus intereses que por la honestidad (30.4.1-2). Por su parte, Salviano sostenía que el imperio estaba muriendo estrangulado por las cuerdas de los impuestos como si fuera a manos de bandidos (De gub. Dei, 4.6.30).

${ }^{517}$ E. g. Frank (1972), que analiza los dichos del historiador tardo-romano asemejándolos con los que Salviano plantearía medio siglo después. Este autor rescata las interpretaciones de S. Dill y N. D. Fustel de Coulanges, seguidas por F. Lot y E. Stein, de la explicación de la caída del imperio centrada en la aparición de una aristocracia "feudal" que evadía en connivencia con la burocracia, haciendo víctimas a los curiales y las clases inferiores, por un lado, y al gobierno central por otro. Algo similar plantea Alföldy (1987), evitando etiquetar las aristocracias tardo-romanas de feudales. Quedará para otro trabajo una crítica exhaustiva de esta tesis, pero valgan ahora los planteos hechos recientemente por Wickham (2005, 56-150) en torno a la continuidad de la maquinaria fiscal hasta el mismo final del imperio. Aunque seamos menos enfáticos que este autor, coincidimos en que no puede explicarse la caída del Estado imperial apelando a una rebeldía fiscal sistemática que se habría iniciado 150 o 200 años antes.

${ }^{518}$ Matthews (2001) desarrolla las complejidades del Código teodosiano como fuente histórica.
} 
través del aparato del Estado ${ }^{519}$. Estos casos no debieron de constituir una rareza en un imperio en el cual el control del emperador sobre todos sus funcionarios era difícil de ejercer $^{520}$. Por otro lado, en opinión del historiador romano las remisiones favorecían generalmente a los ricos ${ }^{521}$. Para Salviano de Marsella la burocracia -en toda su jerarquía- no se dedicaba a otra cosa que saquear y confiscar propiedades, aunque el arquetipo de la corrupción fuese en su opinión el curial, un tirano que asolaba ciudades y pueblos, del cual solo los más poderosos estaban a salvo ${ }^{522}$. Sería pecar de ingenuo tomar literalmente estas diatribas, pero indudablemente permiten constatar que cierto grado de corrupción era corriente. Las propias leyes reconocían su existencia ${ }^{523}$, mientras que el recurso de apelación frente a los abusos de los funcionarios implicaba muchas veces el soborno ${ }^{524}$.

Es dudoso que este último expediente se concretase en algún tipo de protección efectiva cuando era impulsado por sectores ajenos a la aristocracia, máxime cuando en muchas ocasiones los funcionarios a los que se debía recurrir eran los mismos de los cuales se buscaba amparo o estaban relacionados con éstos. Con Graciano, por ejemplo, se determinó que los defensores fueran nombrados por los consejos municipales, lo que en la práctica significaba dejar el cargo a merced de la aristocracia local, que era el grupo que aquellos supuestamente debían controlar ${ }^{525}$. Por ende, si existían abusos fiscales, difícilmente los defensores acudirían en auxilio de algún damnificado que no fuera parte de la aristocracia o personas allegadas -coloni, clientes, etc.

Por otra parte, ciertos personajes parecen haber estado en condiciones de hacer frente a los cobradores de impuestos sin la necesidad de establecer una connivencia con la burocracia, de manera tal de no pagar ellos y evitar el cobro sobre otros. La aparición de milicias privadas en la Galia de fines del imperio podría ser un indicio en esta

\footnotetext{
${ }^{519}$ Amm. Marc., 16.8.11-13, 27.7.1-2, 27.11 y 30.4.1-2.

${ }^{520}$ Sobre los límites del poder central, véase Kelly 1998, 157-162. En lo estrictamente fiscal, el prefecto del pretorio, por ejemplo, podía llegar a tener cierta libertad para determinar el monto a recaudar. Esto al menos parece desprenderse de la negación de Juliano a aprobar un pedido de superindicción por parte del prefecto de las Galias, que este último parece haber interpretado como un agravio personal (Amm. Marc., 17.3.2-5). Frank (1972) exagera el tono, planteando que los prefectos prácticamente actuaban sin control imperial; cf. Kelly 1998.

${ }^{521}$ Amm. Marc., 16.5.15.

${ }^{522}$ De gub. Dei, 4.4.20-21 y 5.4.17-18.

${ }^{523}$ E. g. C. Th., 13.10 .1 (año 311), 7.4 .1 (año 325) y 7.4 .12 (año 364); Nov. Val., 1.3 (año 450); Nov. Mai., 2 (año 458).

${ }^{524}$ Jones 1968, 168-169 y 171-172; Frank 1972, 74

${ }^{525}$ C. Th., 1.29.1-5 (años 368-373) y 1.29.6, (año 387). Valentiniano I había instituido la figura del defensor con el objetivo de proteger a los sectores más vulnerables (Jones 1964, 726-727). El cargo fue desapareciendo, pero Mayoriano intentó restituirlo para proteger los intereses del fisco (Nov. Mai., 3).
} 
dirección ${ }^{526}$. Una ley de Mayoriano, por ejemplo, habla de potentes cuyos actores no pagaban los impuestos de las propiedades que administraban, rebelándose contra los recaudadores y los jueces que actuaban en consecuencia ${ }^{527}$. De todas maneras, las prácticas más frecuentes de evasión seguramente implicaron algún tipo de conexión con la esfera pública mientras el sistema fiscal siguió funcionando con relativa fuerza. En términos generales, que alguien se hiciese con un alto cargo público era motivo de celebración para sus amigos ${ }^{528}$. Más específicamente, el apartado "De patrociniis vicorum" del Código teodosiano reúne una serie de disposiciones legales condenatorias de prácticas clientelares que tenían como objetivo la protección de campesinos contra el cobro de impuestos ${ }^{529}$. Llamativamente las leyes reconocen que dicha protección provenía en ocasiones de la propia burocracia imperial ${ }^{530}$ y aunque no se haga referencia, es probable que muchos de los patronos que no eran funcionarios tuvieran conexiones con el Estado para poder hacer efectiva la evasión. Este parece haber sido el caso de la protección que muchos poderosos de la Galia de c. 440 ofrecían a los campesinos contra el cobro de impuestos según Salviano. Maniobras de este tipo podían perjudicar alternativamente al fisco $^{531}$, al resto de los contribuyentes -que debían hacerse cargo de las obligaciones de los evasores ${ }^{532}$ - o en última instancia a los curiales, que eran responsables del pago de las obligaciones de su jurisdicción, las recaudasen o $\mathrm{no}^{533}$. Finalmente, otra forma de evasión era la dilación en el pago con la esperanza probable de la remisión ulterior o incluso de la obtención de inmunidad fiscal. También en este caso la connivencia con miembros del poder público era de fundamental importancia ${ }^{534}$.

De todas maneras, pueden esgrimirse diversas razones para explicar por qué la mayor parte de la aristocracia accedió de grado más o menos voluntario al pago de los impuestos en el periodo previo a c. 450. En primer lugar, la desmilitarización -a la que haremos referencia en el capítulo 5- colocó a la aristocracia en una posición subordinada desde el punto de vista político al emperador y su ejército. Además, como

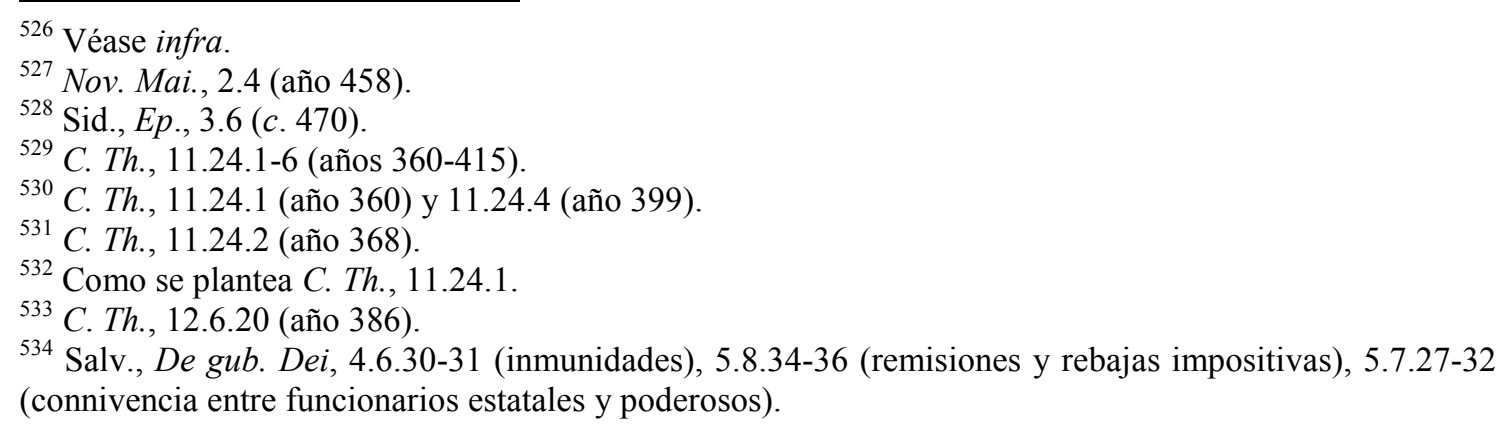


acabamos de ver, los vínculos directos o indirectos con el poder público posibilitaban la evasión, la dilación o las condonaciones fiscales. Finalmente, la búsqueda de cargos obligaba a cierto despojo de los intereses económicos personales en pos de una carrera política que todavía era durante dicho periodo intrínseca a la reproducción social de la propia aristocracia.

No nos parece que debamos interpretar la evasión como una elección que los sectores aristocráticos adoptaron cuando el contexto económico imperial comenzó a dificultar la percepción tributaria como sugiere John F. Drinkwater ${ }^{535}$. Sin embargo, el aumento de las necesidades presupuestarias en un contexto de reducción de la base contribuyente que, como veremos, caracterizó la coyuntura iniciada a comienzos del siglo $\mathrm{V}$ en la parte occidental, debió de restringir las posibilidades de la elite de enriquecerse a través del impuesto y por ende pudo haber favorecido la rebeldía fiscal.

Finalmente, otros historiadores coinciden en la apreciación de que la evasión tributaria por parte de grandes propietarios parece haber sido un mal endémico durante el bajo imperio ${ }^{536}$. Pero esto no obstruía el normal funcionamiento del aparato tributario. El imperio no atravesaba ninguna crisis fiscal cuando el emperador Constantino decretó que se expropiase a aquellas personas que continuamente eludieran sus obligaciones ${ }^{537}$. Por otra parte, el Estado tardo-romano no parece haber sido particularmente corrupto; las entidades políticas organizadas en función de la extracción de tributo suelen tener que hacer frente a este tipo de problemas ${ }^{538}$.

\section{Renta e impuesto}

Merece un apartado propio el problema de la comparación entre el peso del impuesto y los niveles de las rentas. Antes de abordarlo, destaquemos una vez más el hecho de que los grandes terratenientes -o al menos buena parte de ellos- tenían a su alcance resortes políticos que les permitían acceder a reducciones en sus impuestos o ser

\footnotetext{
${ }^{535}$ Drinkwater 1992, 211-212.

${ }^{536}$ Whittaker y Garnsey 1998, 298-299; Wickham 1989, 18.

537 C. Th., 11.7.4: “Quoniam succlamatione vestra merito postulastis, ne qua his, qui praestationes fiscales differunt, reliquorum laxitas proveniret, specialiter praecipimus observari, ut res eorum, qui fiscalibus debitis per contumaciam satisfacere differunt, distrahantur: comparatoribus data firmitate perpetua possidendi etc".

${ }_{538}$ Pero cuando la corrupción, la evasión fiscal y el clientelismo cobraban ímpetu el Estado puede verse seriamente debilitado, como ocurrió a finales de la dinastía Tang en China (Wickham [1985], 11-12, esp. n. 17).
} 
los primeros en beneficiarse de las condonaciones generales, mientras que los pequeños propietarios eran quienes sufrían más directamente el yugo del Estado.

Chris Wickham ha abordado la cuestión a partir de datos provenientes de Egipto y Ravena en el siglo VI. Los de la región africana provienen de un registro completo de impuestos de Antinópolis de probablemente el 527; los de la ciudad italiana de una cesión que el Estado hiciera a la iglesia del lugar, del 555 aproximadamente. Las cifras de Egipto muestran que los gravámenes fiscales superaban en dos veces los de las rentas en la región, mientras que en Ravena la proporción impuesto/renta era de 57 a 43 . Considerando la totalidad del imperio, Wickham calcula que los pequeños propietarios debían de pagar en concepto de carga pública los promedios perfilados en estos documentos o incluso más. En términos de fracción del producto, esto ascendía probablemente a entre un cuarto y la mitad. Con respecto al momento en que el impuesto comenzó a superar en términos relativos a la renta, en su opinión habría que retrotraerse a finales del siglo $\mathrm{IV}^{539}$.

En trabajos anteriores seguimos el análisis de Wickham, considerando que a pesar de la falta de información precisa era posible concluir que en la Galia el impuesto había sobrepasado a la renta durante la primera mitad del siglo $\mathrm{V}^{540}$. Asimismo, implícitamente dimos a entender que los coloni podrían haberse hallado incluso en una posición ventajosa con respecto a los pequeños propietarios, en la medida en que la renta y la parte personal del impuesto podían globalmente ser inferiores a la suma de iuga y capita a la que tenían que hacer frente quienes labraban su propia tierra ${ }^{541}$. Un pasaje del De gubernatione Dei referente a campesinos que aparentemente optaban por convertirse en coloni por conveniencia parecía apoyar el argumento ${ }^{542}$.

Sin embargo, esta hipótesis nos parece ahora discutible. No solo es imposible hacer una estimación del nivel global de la renta en la Galia meridional en el periodo analizado, sino que además los montos debieron de variar sensiblemente incluso a nivel micro regional. Drinkwater ha sugerido que entre c. 400 y c. 450, como resultado de las invasiones bárbaras, la guerra civil, las enfermedades y el hambre, la población gala tuvo que haber sufrido una caída demográfica de importancia que debería de haber derivado -en circunstancias "normales"- en una caída de la renta, dada la mayor

\footnotetext{
${ }^{539}$ Wickham 1989, 13-14.

${ }^{540}$ Sarachu 2005; 2009.

${ }^{541}$ En su momento retomamos la propuesta de Durliat (1990, 22-23) de que el impuesto personal (caput) representaba aproximadamente la vigésima parte del impuesto a la tierra.

${ }^{542}$ Salv., De gub. Dei, 5.8.43. Véase la transcripción en el próximo capítulo, n. 684.
} 
disponibilidad de tierra y la escasez de mano de obra. Omitiendo el hecho de qué es lo que habría de considerarse por "normal" en una economía precapitalista, el autor da cuenta de cómo, no obstante, una serie de cuestiones relacionadas con la evolución particular de las aristocracias y del Estado en la Galia del siglo V debieron de afectar de forma diversa los niveles de renta en distintas regiones. De esta manera las exigencias privadas habrían aumentado en el sur porque a pesar de la escasez de brazos hubo una fuerte demanda de tierra a causa de la inmigración de sectores aristocráticos del norte ${ }^{543}$. Sin embargo, el autor también recoge el testimonio de Salviano referente a quienes optaban por hacerse coloni para aducir que en determinados sitios la renta pudo haber disminuido.

La conclusión que se impone es la de la prudencia en el análisis a falta de datos concretos. Podríamos aventurar que las rentas debieron de ser elevadas, pero en la medida en que dependían de la negociación constante entre tenentes y señores los niveles debieron de variar de un sitio a otro. Por otro lado, habría que poner en duda las pretendidas "ventajas" que conllevaba hacerse colonus de un terrateniente, tanto si se daba el caso de que la renta fuera menor al impuesto como si el propietario de la tierra lograba por los mecanismos que fuese evadir o aminorar la carga fiscal. Es difícil pensar que en el primer caso el campesino hiciese un cálculo económico de conveniencia que supusiese la pérdida de la heredad familiar o que, en el segundo, los beneficios del señor se tradujesen en una reducción de las exigencias a sus tenentes. Volveremos a analizar algunas de estas cuestiones en el capítulo siguiente y estudiaremos el pasaje aludido de la obra de Salviano con mayor detenimiento.

\section{La presión fiscal desde c. 406 en occidente y en la Galia}

El peso global del impuesto alcanzó cotas muy elevadas a comienzos del siglo $\mathrm{V}$, es decir, luego de las invasiones que se produjeron a través del Rin.

Conviene ahora volver los pasos sobre algunos planteos hechos previamente para relacionarlos con la cuestión fiscal. Hemos señalado que los conflictos bélicos debieron de afectar seriamente la producción agraria de las regiones que fueron teatro de operaciones. Los más perjudicados debieron de ser con toda probabilidad los

${ }^{543}$ Drinkwater 1992. 
pequeños campesinos ${ }^{544}$. Por otro lado, los gastos de defensa crecieron al tiempo que los territorios provinciales se perdían frente a los germanos o por impulso de sectores que ya no pretendían formar parte del Estado romano. El inicio de esta coyuntura de aumento del gasto militar debe retrotraerse a la batalla de Adrianópolis del año 378. A partir de ese momento el ritmo de reclutamiento se aceleró, no solo porque fue necesario presentar más efectivos en los frentes de batalla, sino porque la prolongación de los conflictos multiplicó las bajas. Debe tenerse en cuenta además que la demanda de recursos del ejército aumentaba cuando este se encontraba en campaña ${ }^{545}$. Por último, hay que agregar que los requerimientos militares no vinieron solo del frente "externo", sino que también lo hicieron del "interno", constituido por usurpadores y rebeldes. Esto encajaría con los cálculos de la relación global impuesto/producto de Wickham para $c$. 400, referidos anteriormente. La consecuencia lógica de las devastaciones y la pérdida de territorios fue el incremento en las obligaciones de las regiones que aún tributaban, pues las erogaciones del imperio no disminuían. La situación presupuestaria se tornó dramática luego de la pérdida de los ingresos africanos tras la conquista vándala de Cartago en 439, como revelan las leyes de Valentinano y Mayoriano referidas en el capítulo 2 .

El aumento global de la carga fiscal producido entonces desde comienzos del siglo $\mathrm{V}$ se tradujo con toda seguridad en una presión muy dura para buena parte del campesinado. Podemos constatar este fenómeno para la Galia meridional de c. 440 a partir del testimonio de Salviano de Marsella. El carácter dramático de este escrito admonitorio no resta en este caso verosimilitud al relato ${ }^{546}$. Según el presbítero, muchos contribuyentes pobres (tributarii pauperes et egestuosi), presionados por las cargas públicas, no tenían otra opción que ponerse bajo la protección y el cuidado de los poderosos, cediéndoles el derecho a la herencia de sus propiedades a cambio de la promesa de un auxilio que muchas veces no se cumplía ${ }^{547}$. Analizaremos con más detalle las consecuencias de este patrocinium en el siguiente capítulo. Recordemos que

\footnotetext{
${ }^{544}$ Véase Garnsey 2003 sobre la vulnerabilidad de la economía campesina en la Antigüedad.

${ }^{545}$ Lee 2007,402 y 411.

${ }^{546}$ Opina igual a nosotros Lepelley $(1983,150)$; no así Lambert $(2000,130)$.

${ }^{547}$ Salv., De gub. Dei, 5.8 .38 ("tradunt se ad tuendum protegendumque maioribus, dediticios se divitum faciunt et quasi in ius eurum decionemque transcendunt"), 5.8 .39 ("Omnes enim hi qui defendi videtur, defensoribus suis omnem fere substantiam suam prius quam defendantur addicunt") y 5.8 .42 ("quod plerique paupercolurum atque miserorum spoliati resculis suis, et exterminati agellis suis, cum rem amiserint amissarum tamen rerum tributa patiuntur! Cum possessio ab his recesserit, capitatio non recedit! Proprietatibus carent, et vectigalibus obruuntur!"). Sobre el aumento de la presión fiscal en la Galia véase también Drinkwater 1992, 211.
} 
poco antes Paulo Orosio había sostenido que en Hispania los romanos preferían vivir bajo el dominio de los bárbaros antes que pagar impuestos públicos ${ }^{548}$.

Pese a que las reformas implementadas por Diocleciano habían limitado la discrecionalidad en la distribución de las cargas por parte de las civitates, lo cierto es que las aristocracias municipales, o al menos parte de ellas, continuaban imponiendo su voluntad. Por ello Salviano denunció en su De gubernatione Dei al curial como arquetipo de la corrupción pública. En este contexto, un aumento global de las exigencias públicas se traducía en una férrea presión sobre los más vulnerables. Como hemos visto, el sacerdote indica también la existencia de maniobras evasoras por parte de los ricos, consistentes en la dilación en el pago con la esperanza probable de la remisión ulterior o incluso de la obtención de inmunidad fiscal ${ }^{549}$. Sabemos que Sidonio Apolinar obtuvo del emperador Mayoriano una condonación de las cargas públicas para Lyon. Sin embargo, el testimonio de Salviano permite dudar de que el otorgamiento de la gracia hubiese comportado beneficios sustanciales para los sectores más desprotegidos $^{550}$. Por otro lado, debemos recordar que el principio de la solidaridad colectiva, según el cual el conjunto de los contribuyentes de un distrito tenía que hacerse cargo de lo eventualmente adeudado por alguno de ellos también debió de perjudicar a los sectores más vulnerables, particularmente a los campesinos propietarios que no gozaban de la protección de sectores aristocráticos vinculados a los gobiernos municipales $^{551}$.

\section{CRISIS Y SUPERVIVENCIA DEL SISTEMA EN LA GALIA POST-ROMANA}

Ciertamente, esta crisis no supuso el fin inmediato del sistema fiscal en la Galia al sur del Loira. La información disponible permite constatar que continuaron

\footnotetext{
548 Oros., 7.41.7.

${ }^{549}$ Véase supra.

${ }^{550}$ Sid., Carm., 5.574-587, 13.15-21 y 13.35-41.

${ }^{551}$ C. Th., 10.25 (año 406), 11.7.3 (año 320) y 11.24.1 (año 360).
} 
cobrándose impuestos no solo hasta los últimos años del gobierno imperial en la región, sino incluso durante el periodo merovingio ${ }^{552}$.

Como hemos observado en el capítulo 1, hay quienes han sugerido a partir de estas evidencias que los reinos romano-germánicos sostuvieron con éxito el sistema tributario tardo-romano, conservando las características centrales que había tenido desde su implantación a fines del siglo III. No queda entonces más que remitirnos al desarrollo anterior e insistir en que la forma más radical de esta tesis fue esgrimida por los llamados "fiscalistas", pero que sus raíces se prolongan en los planteos de Walter Goffart acerca del carácter de los asentamientos germánicos y, más atrás, en las últimas elaboraciones de Henri Pirenne ${ }^{553}$.

Interesa ahora plantear que aunque los "fiscalistas" no hayan convencido a todos con sus opiniones, hay autores que sostienen que el aparato tributario tardo-romano sobrevivió de manera más o menos estable por lo menos durante el siglo VI e incluso posteriormente. Para Ian Wood, por ejemplo, pese a que resulta difícil aseverar la regularidad en la recolección de impuestos a partir de los dichos de Gregorio de Tours que en su opinión se centra en situaciones excepcionales-, un pasaje de los Decem libri historiae concerniente a una intervención del obispo de Poitiers en favor de la reasignación de los tributos de la ciudad podría ser un indicio en tal sentido ${ }^{554}$. Según este historiador, la referencia anterior sugeriría incluso que las exacciones podían organizarse de manera relativamente efectiva y de forma más o menos justa. En su opinión, el Estado no habría comenzado a encontrar dificultades en el cobro sino en el trascurso del siglo VII ${ }^{555}$.

Actualmente se tiende a sostener más bien la idea de que los reinos sucesores tuvieron serias dificultades para mantener el funcionamiento de la maquinaria fiscal heredada y que los logros fueron dispares según las regiones. Edward James destacó

\footnotetext{
${ }^{552}$ Sid., Ep., 2.1, 5.7, 7.12 y 8.8, que datan aproximadamente de la década de 470. Para el siglo VI tenemos los testimonios de Ces., Serm., 34.3 y 154.2; V. Caes., 1.20 y Greg., Hist., 5.28, 5.34, 6.22, 6.28, 9.30 y 10.7 .

${ }^{553}$ Ya nos hemos referido en el capítulo anterior a la tesis de Goffart sobre los asentamientos de los germanos. Es preciso aclarar, sin embargo, que a diferencia de Durliat, para aquel los impuestos se transformaron en parte en rentas privadas y en parte en servicio militar durante el periodo merovingio (Goffart [1972]; [1982a] y [1982b]).

${ }^{554}$ Greg., Hist., 9.30 ("Childeberthus vero rex discriptores in Pectavo, invitante Maroveo episcopo, iussit abire, id est Florentianum maiorem domus reginae et Romulfum palatii sui comitem, ut scilicet populus censum, quem tempore patris reddiderat, facta ratione, innovata re, reddere deberet. Multi enim ex his defuncti fuerant, et ob hoc viduis orfanisque ac debilibus tributi pondus insiderat. Quod hi discutientes per ordinem, relaxantes pauperes ac infirmus, illos quos iustitiae conditio tributarius dabat censo publico subdiderunt").

${ }^{555}$ Wood 1994, 62-63.
} 
hace algún tiempo que los reyes francos tuvieron poco éxito en el establecimiento de nuevos impuestos y que aquellos que databan de la época romana -particularmente el territorial que gravaba a la población libre propietaria- fueron desapareciendo por el otorgamiento de inmunidades. Un pasaje del Liber in gloria confessorum de Gregorio de Tours retrotrae la inmunidad fiscal de la región lionesa al último cuarto del siglo $\mathrm{V}$. Sin que podamos estar seguros de que la datación sea fidedigna, queda de manifiesto que el origen de la exención era lo suficientemente remoto como para que un obispo viajado y enterado de los asuntos de otras diócesis como el turonense lo ignorase ${ }^{556}$. Por otro lado, es posible que aquellos descendientes de romanos que fueron progresivamente identificándose como "francos" reclamasen la inmunidad fiscal correspondiente a su nueva condición, aunque ella comportase la obligación de servir en la corte o el ejército y presumiblemente debieran pagar otros impuestos como peaje y aduana ${ }^{557}$. Quizás se tratase precisamente de guerreros que ya cumplían con deberes militares.

Más recientemente, Jean Pierre Devroey ha planteado que las posiciones continuistas en materia fiscal pecan de "literalismo" en la lectura de la documentación, sobrestimando las ordenanzas, los textos normativos y subestimando el funcionamiento social real. No hay nada en los Estados bárbaros comparable a los grandes departamentos de la administración central y de las provincias, que sí se perpetuaron en

\footnotetext{
556 62: ("Leonis autem Romani imperatoris filia, cum ab spiritu vexaretur inmundo et per loca sancta duceretur, assidue clamabat nequam spiritus: 'Non hinc egrediar, nisi archidiaconus Lugdunensis adveniat; et nisi ipse me de hoc vasculo quem ad quaesivi eiciat, nullatenus hinc sum egressurus'. Audiens haec imperator, diregit suos in Gallias. Quem illi repertum suppliciter exorant, ut cum eis ad visitandam puellam Roma dignaretur accedere. Ille vero contradicens et se indignum, per quem Christus miracula ostenderet, esse vociferans, admonitus episcopi sui consilio, cum eosdem missos diregit, et ad imperatorem veniens, cum honore suscipitur. Audiens autem de infirmitate puellae, se ad basilicam beati Petri apostoli confert; ibique continuato cum vigiliis et orationibus triduano ieiunio, quarta die per invocationem domini nostri Iesu Christi et crucis vixillo inmundum spiritum a corpore puellae depellet. Qua sanata, tria ei centenaria auri imperator offer; sed ille vir altioris spiritus caducas divitias pro nihilo respuit, dicens: 'Si', inquid, 'me tuis muneribus locupletari desideras, illud quod cunctae proficiet civitati largire'. 'Tributum', ait, 'in tertio circa muros miliario civitatis, quod tuis debetur stipendiis, populis cede. Hoc utriusque animabus salubre beneficium erit. Aurum vero tuum necessarium non habeo. Pauperibus illum pro tua tuorumque felicitate dispensa'. Quod ille non abnuens, aurum pauperibus erogat et tributum petitum civitati concedit. Unde usque hodie circa muros urbis illius in tertio miliario tributa non redduntur in publico").

${ }^{557}$ James 1988, 191-194. Los impuestos de peaje y aduana parecen haber tenido una supervivencia mayor según James, aunque su control parece haber ido pasando del rey y los condes a manos privadas. Véase también Devroey 2003, 240-241. El mencionado cambio de una identidad se inserta en el problema más amplio de la llamada "etnogénesis". James 2006, cap. 5 es una buena introducción al debate en torno a esta cuestión. En su opinión (p. 121), muchos galo-romanos debieron de comenzar a pensarse como francos desde el reinado de Clodoveo, quizás al principio con un sentido meramente político, como súbditos de un rey franco. Ello no era incompatible, por otro lado, con la continuidad de una identidad urbana. Vale decir que alguien podía ser arverno y franco.
} 
oriente. El supuesto "Estado tributario" franco no dejó ni manuales, ni leyes, ni útiles económicos y administrativos que revelen su funcionamiento. Todas las evidencias se reducen, según el autor, a los testimonios antifiscales hallados en Gregorio de Tours en un contexto polémico y en defensa de los intereses de la Iglesia ${ }^{558}$. Sin embargo, Devroey omite mencionar fuentes hagiográficas que, como veremos, avalan la idea de un rechazo generalizado a la tributación.

Por otro lado, Raymond Van Dam ha afirmado que antes que un sistema fiscal propiamente dicho, el cobro de obligaciones públicas durante el siglo VI en la Galia habría obedecido más bien a la capacidad de cada rey para ejercer la intimidación y la subordinación. Los monarcas enviaban condes a las ciudades para obtener tanto juramentos de lealtad como tributos ${ }^{559}$. En tal caso estaríamos en presencia de una explotación que podría entenderse como tributaria en lugar de impositiva, según la distinción que hemos fijado al comienzo del capítulo; no podríamos hablar de una exacción regular más allá de la arbitrariedad. En este sentido, el párrafo siguiente al pasaje de Gregorio de Tours que Wood cita en apoyo a la idea de una pervivencia más o menos estable del cobro apuntalaría, por el contrario, la tesis de la dificultad del poder público para reintroducir una forma estable de percepción de impuestos en jurisdicciones que por la razón que fuera habían dejado de estar gravadas. Dice allí el obispo que luego de que se lograra reorganizar de manera más justa el criterio de cobro de tributos en Poitiers, los oficiales reales se dirigieron a Tours con el objetivo de fijar impuestos a la población local. Para ello se proponían poner en evidencia los registros fiscales del reinado de Clotario (511-561). Gregorio comenta en el pasaje la explicación que dio a los enviados. Aquellos libros fueron quemados por orden del propio Clotario para que no se cobraran más impuestos en Tours. La decisión había sido respetada por su sucesores Chariberto, Sigiberto y Childeberto II, aunque menciona que el conde Gaiso reimpuso ilegalmente el cobro durante un breve periodo ${ }^{560}$. El episodio deja en

\footnotetext{
${ }^{558}$ Devroey 2003, 231-235.

${ }^{559}$ Van Dam 2005, 210.

${ }^{560}$ Greg. Tur., Hist., 9.30 ("Et sic Toronus sunt delati. Sed cum populis tributariam functionem infligere vellent, dicentes, quia librum prae manibus haberent, qualiter sub anteriorum regum tempore dissolvissent, respondimus nos, dicentes: 'Discriptam urbem Toronicam Chlothari regis tempore, manifestum esse, librique illi ad regis praesentiam abierunt; sed, conpuncto per timorem sancti Martini antestitis rege, incensi sunt. Post mortem vero Chlothari regis Charibertho rege populus hic sacramentum dedit; similiter etiam et ille cum iuramento promisit, ut leges consuetudinesque novas populo non infligeret, sed in illo, quo quondam sub patris dominationem statu vixerant, in ipso hic eos deinceps reteneret; neque ullam novam ordinationem se inflicturum super eos, quod pertinerit ad spolium, spopondit. Gaiso vero comes eiusdem temporis, accepto capitulario, quem anteriores scriptores
} 
evidencia que Tours había gozado de una inmunidad fiscal prácticamente ininterrumpida durante al menos tres décadas y media. La postura de Van Dam resulta entonces interesante, pues permite comprender la información disponible acerca de la existencia de tributos públicos no como parte de un continuum que se retrotraería al periodo tardo-romano, sino más bien como sucesivos intentos de reimponer un sistema que ya había entrado en crisis.

La discusión historiográfica podría plantearse ahora en términos de cómo se interpreta dicha crisis. Para Chris Wickham, lo que ocurrió en los reinos vándalo, visigodo o franco, con distintos ritmos y con características particulares, fue que el Estado dejó de interesarse en el cobro de impuestos a causa de que los soldados de sus ejércitos ya no eran asalariados sino que se mantenían a través de la renta obtenida sobre las tierras que ocupaban ${ }^{561}$. Debemos decir que el argumento nos resulta poco persuasivo, en primer lugar porque a priori parece improcedente suponer que el poder público renunciara sin más a la extracción sistemática de excedente. En este sentido, Wickham no puede interpretar sino como una "paradoja" el hecho de que los vándalos conservaran con éxito durante un tiempo considerable un sistema de impuestos que significaba para el Estado unos ingresos desproporcionadamente mayores a los pocos gastos que tenían, a pesar de que luego evalúe su decadencia como un ejemplo paradigmático de cómo un aparato fiscal podía colapsar en condiciones favorables si no era estructuralmente necesario para el sistema político ${ }^{562}$. Lo cierto es que resulta difícil explicar qué los llevó a mantener por un tiempo el sistema si no partimos de la base de

\footnotetext{
fecisse commemoravimus, tributa coepit exegere. Sed ab Eofronio episcopo prohibitus, cum exacta parvitate ad regis direxit praesentiam, ostendens capitularium, in quo tributa continebantur. Sed rexingemiscens ac metuens virtutem sancti Martini, ipsum incendio tradedit; aureus exactus basilicae sancti Martini remisit, obtestans, ut nullus de populo Toronico ullum tributum publico redderit. Post cuius obitum Sigyberthus rex hanc urbem tenuit nec ullius tributi pondus invexit. Sic et nunc XIIII. anno Childeberthus post patris obitum regnans, nihil exegit, nec ullo tributi onere haec urbs adgravata congemuit. Nunc autem potestatis vestrae est, utrum censeatis tributum, an non; sed vidite, ne aliquid noceatis, si contra eius sacramentum ambulare disponitis'. Haec me dicente, responderunt: 'Ecce librum prae manibus habemus, in quo census huic populo est inflictus'. Et ego aio: 'Liber hic a regis thesauro delatus non est nec umquam per tot convaluit annus. Non est mirum enim, si pro inimicitiis horum civium in cuiuscum que domo reservatus est. Iudicavit enim Deus super eos, qui pro spoliis civium no strorum hunc post tanti temporis transacto spatio protulerunt'. Dum autem haec agerentur, Audini filius, qui librum ipsum protulerat, ipsa die a febre correptus, die tertia expiravit. Post haec nos transmisimus nuntios ad regem, ut, quid de hac causa iuberit, mandata remitteret. Sed protinus epistulam cum auctoritate miserunt, ne populus Toronicus pro reverentia sancti Martini discriberetur. Quibus relictis statim viri, qui ad haec missi fuerant, ad patriam sunt regressi").

${ }^{561}$ Wickham 2005, 80-124.

${ }^{562}$ Wickham 2005, 91-92.
} 
que efectivamente hubo una voluntad decidida de perpetuarlo por parte de los reyes ${ }^{563}$. Esto vale para juzgar lo sucedido en los otros reinos post-romanos. Pero además la documentación disponible contradice su tesis. En la Galia contamos, por un lado, con referencias a episodios de resistencia al pago de los gravámenes que nos han llegado a través de los escritos de Gregorio de Tours ${ }^{564} \mathrm{y}$, por otro, con evidencias de presencia de impuestos en el valle del Loira hasta incluso los comienzos del siglo IX $^{565}$. Es cierto que las primeras no son abundantes, pero ello no invalida la posibilidad de que haya existido una oposición sorda y constante de la que no nos ha llegado noticia. La última de las referencias de Gregorio de Tours es un indicio en tal sentido: los recaudadores habían encontrado cada vez mayores dificultades para continuar con el cobro de impuestos en Clermont Ferrand. Una resistencia de tal guisa explicaría los niveles relativamente bajos de tributación que pueden deducirse de otros pasajes de la obra del turonense ${ }^{566}$, así como la existencia de una extendida intolerancia a que los reyes francos se atribuyesen la potestad de modificar el statu quo fiscal a través de la legislación, la imposición de nuevas cargas o la persecución de la evasión, según revelan fuentes hagiográficas ${ }^{567}$. Además, es preciso recordar los constantes pedidos de

\footnotetext{
${ }^{563}$ Los historiadores suelen coincidir al menos en la existencia de esta voluntad, no así en el grado de éxito en la reproducción de las estructuras administrativas heredadas.

${ }^{564}$ Greg. Tur., Hist., 3.36 ("Franci vero cum Parthenium in odio magno haberent, pro eo quod eis tributa ante dicti regis tempore inflixisset, eum persequi coeperunt. Ille vero in periculum se positum cernens, confugium ab urbe facit ac duobus episcopis suppliciter exorat, ut eum ad urbem Treverecam deducentes, populi saevientes seditionem sua prae dicatione conpraemerent"), 5.28 ("Chilpericus vero rex discriptiones novas et gravis in omne regno suo fieri iussit. Qua de causa multi relinquentes civitates illas vel possessiones proprias, alia regnas petierunt, satius ducentes alibi peregrinare quam tali pericolo subiacere. Statutum enim fuerat, ut possessor de propria terra unam anforam vini per aripennem redderit. Sed et alii functionis infligebantur multi tam de reliquis terris quam de mancipiis; quod implere non poterat. Lemovicinus quoque populus, cum se cernerit tali fasci gravari, congregatus in Kalendas Martias Marcumque refrendarium qui haec agere iussus fuerat, interficere voluit; et fecisset utique, nisi eum episcopus"), 7.15 ("Habebat tunc temporis secum Audonem iudicem, qui ei tempore regis in multis consenserat malis. Ipse enim cum Mummolo praefecto multos de Francis, qui tempore Childeberthi regis seniores ingenui fuerant, publico tributo subegit. Qui post mortem regis ab ipsis spoliatus ac denudatus est, ut nihil ei, praeter quod super se auferre potuit, remaneret. Domus enim eius incendio subdederunt; abstulissent utique et ipsam vitam, nisi cum regina aeclesiam expetisset") y 10.7 ("In supradicta vero urbe Childeberthus rex omnem tributum tam eclesiis quam monasteriis vel reliquis clericis, qui ad eclesiam pertinere videbantur, aut qui cumque eclesiae officium excolebat, larga pietate concessit. Multum enim iam exactores huius tributi expoliati erant, eo quod per longum tempus et succedentum generationes, ac divisis in multis partibus ipsis possessionibus, colligi vix poterat hoc tributum; quod hic, Deo inspirante, ita praecipit emendare, ut, quod super haec fisco debitur, nec exactore damna percuterent nec eclesiae cultorem tarditas de officio aliqua revocaret").

${ }_{565}$ Wickham 2005, 111-112.

${ }^{566}$ Greg. Tur., Hist., 5.28; Wickham 2005, 108. Esta cifra implicaría regresar a guarismos similares a los del alto imperio en un contexto distinto, de relajación de los vínculos de dominación privado.

${ }^{567}$ Goffart [1982b], 225.
} 
inmunidad fiscal de eclesiásticos y laicos, a los que los reyes debieron atender en la búsqueda de apoyo político $^{568}$.

\section{UNA HIPÓTESIS EXPLICATIVA SOBRE LA CRISIS FISCAL}

Creemos que para poder comprender la crisis del sistema fiscal debería atenderse a la dinámica de los actores involucrados en su funcionamiento, es decir, al poder público y los contribuyentes. Esto impone una recapitulación.

El sistema funcionó sin mayores sobresaltos hasta c. 400 porque el Estado logró instrumentar el cobro a través de unas aristocracias locales que, en su mayoría, o bien se beneficiaban en el proceso de exacción a partir de los mecanismos ya mencionados, o bien lograban aminorar el peso sobre sus tierras gracias al contacto con las esferas municipales y/o centrales del poder público. Esto suponía la exclusión de ciertos segmentos de estas elites, aquellos desvinculados de las autoridades locales como resultado de las luchas facciosas por el acceso al poder ${ }^{569}$. Estos sectores sí eran vulnerables a las maniobras de los curiales $^{570}$. En una carta del año 474, cuando la situación financiera del imperio hacía tiempo que era crítica, Sidonio le advertía a un amigo que de persistir en su decisión de no involucrarse en los asuntos públicos iba a sufrir la carga de los agentes recaudatorios ${ }^{571}$. Con todo, el hecho de que el impuesto no representara a inicios de siglo una parte excesivamente grande del producto bruto total del imperio facilitó el funcionamiento de esta dinámica.

El cambio comenzó a producirse desde inicios del siglo $\mathrm{V}$, con el aumento progresivo de una carga tributaria que ya era pesada. Pero ello no explica por sí solo la rebelión contra el fisco, sino que es más bien el contexto global de crisis, desatado a

\footnotetext{
${ }^{568}$ Greg. Tur., Hist., 4.2, 9.30 y 10.7; Goffart [1982b], 226-229; Devroey 2003, 242.

569 Así como presupuso un proceso previo de sujeción de las aristocracias fundiarias a la burocracia cívico-militar que se hizo con el control del Estado imperial durante el siglo III (García Mac Gaw 2003b). ${ }^{570}$ Incluso los propios curiales podían resultar las víctimas si no lograban recaudar lo debido. Sin embargo, esto probablemente no fuera tan frecuente como pretendió la historiografía tradicional (Lepelley 1983).

571 Sid., Ep., 8.8.3: "Neque dixerim sapienti viro rem domesticam non esse curandam, sed eo temperamento, quo non solum quid habere sed quid debeat esse consideret. Nam, si ceteris nobilium studiorum artibus repudiatis sola te propagandae rei familiaris urtica sollicitat, licet tu deductum nomen a trabeis atque eboratas curules et gestatorias bratteatas et fastos recolas purpurissatos, is profecto inveniere, quem debeat sic industrium quod latentem non tam honorare censor quam censitor onerare".
} 
partir de las invasiones bárbaras, el que avivó el conflicto social general, quebrando incluso en muchas regiones la voluntad aristocrática de continuar apoyando al Estado imperial $^{572}$. En la Galia del norte pudo haber ocurrido incluso antes y con mayor fuerza que en el $\operatorname{sur}^{573}$.

En torno al año 440, según Salviano, no todos los patronos que protegían a los evasores actuaban en connivencia con las autoridades locales y quienes lo hacían estaban de todos modos socavando el statu quo dada la situación de reducción significativa de la base contribuyente y el aumento galopante de las necesidades fiscales. En el mediano plazo la inestabilidad del orden público y las guerras continuas en la Galia meridional redundaron en la multiplicación de núcleos campesinos autónomos, nutridos no solo de quienes huían del fisco, sino también de esclavos y, posiblemente, coloni que escapaban de sus señores ${ }^{574}$. Este escenario de lucha social intensa caracterizó el periodo post-romano; en los reinos francos, los funcionarios se vieron impedidos de mantener con éxito el sistema fiscal, a pesar de que a todas luces lo intentaron.

Por otro lado, ha sido esgrimido como factor explicativo central para el derrumbe del sistema fiscal el papel jugado por los sectores aristocráticos. Devroey destaca que la resistencia a las reiteradas tentativas de regenerar el impuesto en la Galia provino principalmente de los potentes. Esto puede verse claramente no solo en los testimonios ya mencionados de Gregorio de Tours y de ciertos hagiógrafos, sino también en la imposición durante la alta Edad Media del principio generalizado de que el rey debía vivir de lo suyo y ser liberal, que no podía establecer de cara a sus súbditos una relación de inequidad ${ }^{575}$. Hemos analizado esta ideología del don en el capítulo precedente. Pero el cambio no es meramente de orden cultural; el fundamento es la fusión de las elites bárbaras con sectores de la antigua aristocracia senatorial romana deseosos de servir a los reyes militar o civilmente. Como plantea Matthew Innes, los asentamientos bárbaros crearon una clase de terratenientes libres de impuestos, cuya

\footnotetext{
${ }^{572}$ Liebeschuetz 2001, 342 y 348-350.

${ }^{573}$ Podría aducirse - aunque se trate de una especulación difícil de probar- que la imprecisa mención de Amiano Marcelino (27.2.11) a ciertas batallas poco glorificantes ganadas en la región por el emperador Valentiniano I encerrase una referencia a levantamientos antifiscales. E. A. Thompson ([1952], 344) y G. E. M. de Ste. Croix $(1988,557)$ piensan que lo que el emperador reprimió fueron levantamientos de bagaudas (interpretados como rebeliones campesinas), lectura que no es necesariamente incompatible con la anterior.

${ }_{574}^{57}$ Ampliaremos el tratamiento de la cuestión en el siguiente capítulo.

${ }^{575}$ Devroey 2003, 242-244.
} 
posición estaba anclada en el servicio de armas al rey. Este proceso impuso una forma de libertad que difería de la del ciudadano con respecto al emperador, la cual admitía la posibilidad de estar sujeto a cargas fiscales. En la medida en que las antiguas familias senatoriales se convirtieron en servidores del rey pudieron aspirar a estar exentas de la imposición fiscal ${ }^{576}$. El fenómeno está íntimamente relacionado con el proceso de etnogénesis que borró las distinciones entre bárbaros y romanos para el siglo VII ${ }^{577}$.

De todas formas, Devroey plantea que la eliminación de los impuestos no debió de tener mayor relevancia para los campesinos; en todo caso, el producto de su trabajo se lo habrían quedado en adelante los aristócratas a título individual. Este argumento retoma la tesis de Goffart según la cual los impuestos se convirtieron gradualmente en rentas y va en contra de la caracterización más general de la economía temprano medieval del propio Devroey. Profundizaremos esta cuestión en los capítulos siguientes, pero adelantemos una vez más que en nuestra opinión, el poder de la aristocracia sobre aquellos de status inferior también se hallaba en crisis en el periodo analizado. En este sentido, es probable que la rebeldía fiscal fuera impulsada tanto por los sectores aristocráticos como por el resto de los contribuyentes ${ }^{578}$.

\footnotetext{
${ }^{576}$ Innes 2006, 66.

${ }^{577}$ Innes 2006, 42-45. Véase supra la referencia a la cuestión de la etnogénesis.

578 Devroey 2003, 242-244; Goffart [1982b]. James $(1988,192)$ plantea la posibilidad de que la reluctancia a la imposición de nuevos impuestos por parte de los reyes merovingios proviniese de las reacciones populares.
} 


\title{
ARISTÓCRATAS Y CAMPESINOS (I):
}

\author{
c. $400-$ c. 480
}

Este capítulo y el próximo están dedicados a los vínculos entre la aristocracia y el campesinado. El presente se inicia con una definición aproximada de ambos grupos sociales y continúa con un análisis de la cuestión circunscripta, grosso modo, al periodo comprendido entre los inicios del siglo $\mathrm{V}$ y la desaparición final del poder imperial en la Galia.

\section{CUESTIONES DE DEFINICIÓN}

\section{Aristócratas}

Según Michael T. W. Arnheim, la "nobleza" o "aristocracia" del bajo imperio romano estaba compuesta únicamente por los senadores de nacimiento clarissimi, es decir, por los hijos de los senadores ${ }^{579}$. Esta definición excluye no solo a los sectores socialmente dominantes a nivel local, sino incluso a quienes habían obtenido el rango

\footnotetext{
${ }^{579}$ Leyes emitidas durante los reinados de Valentiniano y Valente institucionalizaron las distinciones de status dentro del orden senatorial. Se establecieron tres grados: clarissimi (gobernadores consulares y algunos burócratas inferiores); spectabiles (gobernadores proconsulares, los cuatro comites consistoriani, duces y altos funcionarios militares) y los illustres (prefectos del pretorio, prefectos urbanos, cónsules y magistri militum y altos generales) (Jones 1964, 143-144 y 528-529). Por otro lado, como hemos dicho, el rango de clarissimi era a su vez hereditario (Heather 1998, 190-191).
} 
senatorial a partir de una concesión imperial -los considerados por los clarissimi de nacimiento como novi nobiles ${ }^{580}$. La interpretación de este autor retoma fundamentalmente la mirada que la cúspide de la elite tenía de lo que debía considerarse como nobilitas y resulta así poco operativa para los objetivos de este capítulo y de esta tesis; no obstante, es útil para iniciar una discusión conceptual. Utilizaremos la noción de "aristocracia" en un sentido más lato. Siguiendo a Chris Wickham, podemos considerarla más bien una elite política que en general era propietaria de tierras y que tenía capacidad para ejercer poder gracias a su condición. La caracterización es amplia y vaga, pero resulta adecuada para englobar tanto a la poderosa aristocracia de la época tardo-romana como a la más débil del mundo temprano medieval ${ }^{581}$.

Los distintos sectores que componían este grupo compartían en mayor o menor medida una misma forma de sustento económico -la explotación de campesinos en tierras de su propiedad- y un acceso directo, indirecto o potencial al poder político. Ello no implica soslayar las diferencias entre ellos, sino considerarlas como distinciones de status entre miembros de una misma clase. En este sentido, es pertinente retomar la vieja discusión historiográfica existente entre aquellos que estiman que las sociedades de la Antigüedad clásica deben analizarse a partir de las categorías de "orden" y "status" y quienes se inclinan por estudiarlas según la categoría de "clase social" de Karl Marx. En su estudio seminal sobre la economía antigua de 1973, Moses I. Finley propuso que la existencia de distinciones jurídicas (como el derecho de ciudadanía o la pertenencia a un orden estamental determinado) y de status (como la definición de un grupo según criterios de ascendencia, procedencia, comportamiento público, etc.) tuvieron tal importancia en la Antigüedad clásica que el concepto de "clase social" definido de acuerdo al posicionamiento de los actores sociales en relación a los medios de producción y el proceso productivo resultaba poco operativo para el análisis

\footnotetext{
${ }^{580}$ Arnheim 1972, 8.

${ }^{581}$ Wickham 2005, 153-154. El autor menciona además seis criterios a modo de guía para identificar estos sectores: distinción de ascendencia; riqueza basada en la tierra; posición en una jerarquía oficial; favor imperial o real (lo que los alemanes llaman Königsnähe, la "cercanía al rey"); reconocimiento por parte de otros líderes políticos y estilo de vida. En su opinión, ninguno de ellos debe considerarse como autónomo, mientras que el reconocimiento o reputación tiende a depender de la performance del miembro en los otros cinco. Esta caracterización a la manera de un "tipo ideal" weberiano nos interesa menos, en la medida en que estos conceptos suelen estar construidos a partir de selecciones más o menos arbitrarias de atributos comunes de aristocracias de distintos casos históricos. Se corre el riesgo de oscurecer antes que iluminar la comprensión del sujeto histórico concreto que se pretende estudiar, como bien demuestra Laura da Graca (2008, 288-293) para el caso de las aristocracias francas de los siglos VI-VII, propietarias de grandes extensiones de tierras pero incapaces de explotarlas eficientemente.
} 
sociológico $^{582}$. Geoffrey E. M. de Ste. Croix lo criticó duramente años más tarde en su Lucha de clases en el mundo griego antiguo, reivindicando el valor heurístico del concepto de "clase social" y su importancia medular para la comprensión de la sociedad antigua, sin desechar por ello la importancia que tenían los grupos jurídicos en cuanto a los privilegios y deberes que entrañaban ${ }^{583}$. El nudo del problema no es otro que el hecho de que la explotación se producía por medio de una coacción extraeconómica. Un concepto atractivo, que incorpora en una relación jerárquica a los mencionados anteriormente, es el de "clase estamental" (ständische Klassen), pensado por Ludolf Kuchenbuch y Brend Michael para el campo de la historia medieval. Para ellos, la fusión estructural de economía y política significa que las clases económicas aparecen “trabadas" en una estructura estamentaria jurídico-política estratificada verticalmente y diferenciada horizontalmente (local y regionalmente) ${ }^{584}$. De acuerdo con estos criterios, aquello que Arnheim entiende por aristocracia no sería más que un sector diferenciado estamentalmente del resto de su clase. El concepto resulta operativo a su vez para el estudio del campesinado, en tanto dentro de este también existían distinciones jurídicas fundamentales, como entre servi y libres ${ }^{585}$.

La jerarquía eclesiástica también formaba parte de la aristocracia. Desde el siglo IV sus miembros se convirtieron paulatinamente al cristianismo y comenzaron a apropiarse de los cargos de mayor rango dentro de las iglesias ${ }^{586}$. Este desarrollo está bien documentado para la Galia meridional, cuyas sedes episcopales -al menos en las ciudades más importantes- comenzaron a ser ocupadas por las principales familias locales a partir del siglo $\mathrm{V}^{587}$. Su cronología precede a regiones con una mayor cantidad de senadores como Italia ${ }^{588}$. Por otro lado, el mundo monacal también fue penetrado por estos sectores, que fundaron y lideraron algunas de las comunidades más importantes

\footnotetext{
${ }^{582}$ Finley [1973], cap. 2.

583 de Ste Croix 1988, cap. 2 (esp. 116-118).

${ }^{584}$ Kuchenbuch y Michael [1977] 1986, esp. 39.

${ }^{585}$ Véase infra la misma cuestión para el estudio del campesinado. Sobre la utilización del concepto de "clase estamental" véase también Astarita 2001, 30.

${ }^{586}$ Salzman 2002. Véase también Liebeschuetz 2001, 155-167, sobre la posición de los obispos en las ciudades occidentales entre los siglos V y VI.

587 Van Dam 1985, 141-156; Mathisen 1989, 7-9; Jones 2011, 117-128. En la Vita Eutropi, el protagonista rechaza convertirse en obispo de Orléans porque la sede no tenía el status ni la riqueza suficientes (véase la referencia en Mathisen 1999, 19, n. 5).

${ }^{588}$ Rapp 2005, 190-191.
} 
del periodo; el caso del monasterio de Lérins - “cuna de obispos”- es quizás el más destacado $^{589}$.

Una cuestión más complicada supone la inclusión dentro de nuestro concepto de aristocracia de los escalafones más elevados del ejército. A comienzos del siglo IV se consolidó la división entre las esferas civil y militar del poder público imperial, profundizándose así el carácter no guerrero de los sectores aristocráticos tradicionales $^{590}$. Los altos mandos quedaron entonces en manos de generales de carrera, unos cuantos de origen germánico ${ }^{591}$. Sin embargo, esta realidad comenzó a transformarse con el correr del siglo V. Charles Whittaker planteó hace varios años que el fenómeno de soldados (y más probablemente oficiales) adquiriendo tierras fue in crescendo desde probablemente el siglo II, pero adquirió vigor, particularmente en las regiones fronterizas, durante el siglo $\mathrm{IV}^{592}$. Por otro lado, aparecieron milicias privadas comandadas por aristócratas; contamos con legislación de los siglos IV y $\mathrm{V}$ que evidencia este hecho (una ley en particular denuncia y castiga la recurrente práctica de que los soldados entrasen al servicio de privados ${ }^{593}$ ). De todos modos, creemos que Whittaker exagera la magnitud de la "fusión" entre la vieja aristocracia romana y los nuevos guerreros germanos (landlords devenidos en warlords y viceversa), sobre todo si analizamos el siglo IV y las regiones no fronterizas ${ }^{594}$. En estas últimas la propiedad de la tierra continuó estando durante buena parte del siglo $\mathrm{V}$ en manos de la vieja elite. Sin embargo, tampoco parece apropiado fechar el proceso de militarización de esta última hacia fines del siglo VI, como pretende Wickham ${ }^{595}$. Resultan convincentes en este punto los planteos de Matthew Innes, quien fecha más tempranamente la fusión de

\footnotetext{
${ }^{589}$ Nouailhat 1988; Mathisen 1989, 76-84; Wood 1994, 22-24. De todos modos, es importante señalar que durante el siglo $\mathrm{V}$ se crearon muchos monasterios menores en la Galia como resultado de emprendimientos individuales. Se trató de comunidades pequeñas e informales, establecidas a modo de retiro religioso por los aristócratas en sus casas o villae para su círculo más íntimo. Su cuantía resulta incierta y es posible que se disolvieran con la muerte de sus fundadores. Por otro lado, también se construyeron durante esa centuria grandes basílicas sobre tumbas o reliquias de santos que eran servidas por el clero o los monjes de un monasterio ligado (Dunn 2003, 90-92).

${ }^{590}$ Carrié y Rousselle 1999, 652-665; Wickham 2005, 158. La exclusión de los senadores del comando de legiones se retrotrae a Galieno (Campbell 2005, 117-118).

${ }^{591}$ No obstante, muchos generales recibían posteriormente el rango senatorial (Jones 1964, 143-144 y 528-529).

${ }^{592}$ Whittaker (1993b, 284) cita como ejemplo los casos de Arbogasto y Merobaudes, líderes francos al servicio de Roma, ambos con propiedades territoriales en el imperio. Sobre sus carreras, véase respectivamente PLRE, 1, 95-97 y 598-599.

${ }^{593}$ C. Th., 7.1.15 (año 396): "Si quis posthac militem in privato obsequio repertus fuerit retinere, quinque libras auri multae nomine feriatur". Véanse además las diecisiete leyes agrupadas en C. Th., 7.18.

${ }^{594}$ Whittaker 1993 b.

595 Wickham 2005, 159.
} 
al menos parte de la aristocracia senatorial con las elites bárbaras ${ }^{596}$. En las cartas de Sidonio encontramos testimonios en apoyo de esta tesis ${ }^{597}$. El servicio militar permitía estrechar lazos con el rey y de tal modo acceder a la concesión de tierras, un beneficio no menor para una elite que había sufrido y estaba sufriendo la expropiación de sus tierras. La alternativa era la carrera episcopal ${ }^{598}$.

En línea con los criterios argumentales esbozados anteriormente, deberemos tener en cuenta que aquello que entendemos por "aristocracia" en el periodo analizado fue cambiando sensiblemente su fisonomía, pues por un lado los líderes militares comenzaron a controlar de manera privada ciertos territorios (desde el siglo IV sobre todo en la región renana y en el norte de la Galia, pero con el fin del imperio también en el sur) y por otro algunos miembros de antiguas familias de la elite romana se transformaron en guerreros (mientras otros continuaron ocupando cargos episcopales, como lo hicieran desde el siglo V). La razón de la exclusión de los sectores castrenses de la categoría de aristocracia durante el periodo en el que continuó existiendo el Estado imperial obedece a que tenían una lógica de reproducción social distinta de la del terrateniente. Como burocracia militar estos generales y soldados, en su mayoría germanos $^{599}$, vivían de la paga del Estado y por ende eran favorables al orden fiscal romano. La aristocracia terrateniente, en cambio, solo lo era en tanto se beneficiase de sus frutos por estar directa o indirectamente vinculada al aparato burocrático; pero en cualquier caso el impuesto afectaba económicamente a sus miembros a título individual $^{600}$. Esta distinción es de enorme importancia para el análisis de la situación de la Galia meridional de la primera mitad del siglo V (y antes), cuando la desmilitarización de las aristocracias todavía era una realidad palpable.

\section{Campesinos}

Seremos un poco más breves en este apartado. Es oportuno comenzarlo con la caracterización que hace Theodor Shanin de la sociedad campesina, pero no para

\footnotetext{
${ }^{596}$ Innes 2006, 65-67.

${ }^{597} \mathrm{Sid}$, Ep., 3.3 (474), 5.12 (474) y 5.16 (474).

598 Gilliard 1979.

${ }^{599}$ Lee 1998, 222-224; Whitby 2000, 290-291.

${ }^{600}$ Véase el capítulo 4. Un caso de aristócrata propietario de tierras y vinculado directamente al poder político central como burócrata fue el de Ausonio, en una de cuyas cartas deja en evidencia que el salario oficial no era ni indigno, ni desdeñable (Ep., 8.27-34).
} 
adoptarla sino para descartarla. Este autor considera campesina una sociedad en donde la granja se presenta como la unidad básica de su organización. El jefe de la casa y su familia trabajan la tierra para consumo personal y, eventualmente, para generar un excedente del cual se apropian los sectores dominantes. Su principal actividad económica está constituida por una agricultura de bajo nivel relativo de especialización, de modo que la tenencia de la tierra se convierte en el factor decisivo de la estratificación social en términos de riqueza, poder y prestigio. Por otro lado, las sociedades campesinas poseen en su opinión una cultura tradicional específica, relacionada con la forma de vida de las pequeñas comunidades; la aldea provee, además, de vínculos de parentesco y de cooperación laboral. Por último, el campesinado se caracteriza por estar subordinado política, económica y culturalmente a "outsiders".

Como veremos, hay varios puntos de su definición que se adaptan mal al mundo tardo-romano y temprano medieval (para el segundo, por ejemplo, la última de las consideraciones). Shanin caracteriza como "marginales" a grupos que cuantitativa y cualitativamente fueron relevantes en el periodo y región analizados en esta tesis y que no pueden dejar de considerarse como campesinos. Son los casos de los trabajadores agrícolas sin lote de tierra propio - o con uno insuficiente para la propia sustentaciónque se ganan la vida como jornaleros rurales o urbanos; los habitantes rurales que obtienen sus principales ingresos de la artesanía y el comercio y que a menudo trabajan cierta cantidad de tierra; los agricultores que viven más o menos aisladamente y aquellos propietarios que han logrado evitar la subordinación. Por otra parte, una definición como la de este sociólogo no es operativa a la hora de comprender cómo esos distintos grupos se relacionaban entre sí y con los otros sectores en el periodo analizado $^{601}$.

Resulta más conveniente, por lo tanto, adoptar un sentido general del concepto. Proponemos entender por "campesinos" a los pobladores rurales que vivían de la explotación de la tierra que habitaban con su familia, fueran o no propietarios de ese suelo y sin importar su estatuto jurídico. A partir de esta definición "mínima" profundizaremos la comprensión de nuestro objeto de estudio analizando sus atributos

\footnotetext{
${ }^{601}$ Se trata de un "tipo ideal" construido a partir de una combinación de rasgos de distintas sociedades campesinas concretas. Véase supra n. 3, sobre la inconveniencia en la utilización de tipos ideales.
} 
históricamente determinados. Fundamental en este punto será la valoración de sus vínculos con los sectores aristocráticos ${ }^{602}$.

Retomando los planteos hechos anteriormente en torno al concepto de "clase estamental", proponemos finalmente jerarquizar en el análisis la situación socioeconómica de los grupos sociales por sobre las condiciones legales sin desmerecer la incidencia de estas últimas. Recientemente, Alice Rio ha puesto en evidencia a partir del análisis de las formulae de los siglos VI a IX y de los polípticos carolingios que el estatuto jurídico era una dimensión mucho menos determinante de la condición de vida de los campesinos que su situación concreta en el contexto comunitario y, cuando se trataba de tenentes, en relación al propietario legal de la tierra que explotaba ${ }^{603}$. La autora plantea además la sugerente hipótesis de que esta realidad podría retrotraerse al periodo tardo-romano, para el que lamentablemente no contamos con una documentación similar a las formulae ${ }^{604}$. En lo que sigue, intentaremos en parte abonar a esta idea para la región de la Galia meridional. En nuestra opinión, la situación del campesinado $c .400$ fue diametralmente distinta a la de $c$. 550/600 precisamente porque a pesar de la continuidad de la existencia de servi y coloni fue diferente su realidad socioeconómica.

\section{ARISTOCRACIA Y CAMPESINADO}

\section{La gran propiedad}

Tradicionalmente, historiadores de distintas corrientes que se han dedicado al estudio del mundo antiguo han coincidido en que el periodo bajo imperial se caracterizó - particularmente en occidente- por la concentración de la riqueza en pocas manos ${ }^{605}$.

\footnotetext{
${ }^{602}$ Shanin 1972.

${ }^{603}$ Las formulae revelan por ejemplo que los servi podían tener propiedades, recibir donaciones de tierras o pagos por servicios y formar parte de los ejércitos. Muestran además que la servidumbre podía ser temporal y reversible y que incluso personas libres con propiedades se vendían a sí mismas (Rio 2009, 223-232).

${ }^{604}$ Rio 2009, 223. Disentimos con esta autora cuando plantea que la cuestión del status personal era una "estrategia" en manos de los campesinos o que estos disponían de su libertad como de una "mercancía" (Rio 2009, 234-235). Véase la crítica a Allen Jones en el próximo capítulo.

${ }^{605}$ Con matices y desde posturas interpretativas diversas sostenían esto Jones (1964, 767-823), Finley ([1973], 131-171 y 1982, 160-194), de Ste. Croix (1988, 542-586) y Alföldy (1987, 212-290). Incluso Brown ([1971], 46-56 y 151), que en muchos aspectos promovió una profunda renovación de los estudios
} 
Para citar un ejemplo, Finley sostuvo que los últimos siglos de la Antigüedad fueron los de mayor concentración de la propiedad privada de la tierra. La acumulación de la propiedad territorial fue un proceso ininterrumpido que se dio a costa de los pequeños propietarios dado el cese de la incorporación de nuevos territorios al imperio ${ }^{606}$. Las prospecciones arqueológicas han demostrado por su parte la presencia de grandes villae en los siglos finales del imperio, particularmente en occidente ${ }^{607}$.

Pero antes de proseguir con el examen de la gran propiedad en la Galia, es necesaria una aclaración con respecto a qué se entiende aquí por villa. No solo los romanos utilizaban este término para nombrar cosas diferentes (durante la Antigüedad tardía incluso se empleaba para referirse a una aglomeración aldeana), sino que tampoco existe unanimidad de criterio entre los investigadores modernos. Para los historiadores del arte la villa se identifica específicamente con la pars urbana de una finca con unas determinadas características arquitectónicas (habitaciones destinadas a baños; utilización de mosaicos decorativos; etc.). El sentido que le daremos aquí, en cambio, es el seguido en general por arqueólogos e historiadores: una explotación agrícola que tenía una parte residencial más o menos importante y construida en materiales sólidos, a la manera romana ${ }^{608}$.

En la Galia meridional es clara la presencia de grandes propiedades en el siglo V. En principio, contamos con gran cantidad de datos que testimonian la presencia de sectores aristocráticos galo-romanos en los siglos IV y $\mathrm{V}^{609}$. Se trataba, como hemos visto, de una aristocracia civil, anclada en la tierra. Pero hay información más precisa, tanto textual como arqueológica, que permite hacerse una idea de la magnitud de la gran propiedad en el periodo y región analizados. Salviano dedica pasajes extensos de su $D e$ gubernatione Dei a la descripción del accionar de potentes que se apropiaban de las tierras de sus vecinos más humildes ${ }^{610}$. En su Ad Ecclesiam, por otro lado, indica la existencia de "fundos interminabiles" 611 . Otras referencias son más puntuales. E1 aquitano Paulino de Pella se exilió en Marsella, donde invirtió en el mejoramiento de las

del periodo, coincidía sobre estos lineamientos generales. Whittaker y Garnsey 1998, Marcone 1998 y Ward-Perkins 2000 son referencias más recientes.

${ }^{606}$ Finley 1982, 172-175.

${ }^{607}$ Véase por ejemplo Dyson 2003, 90-95.

${ }^{608}$ Leveau 2002, 5-26

${ }^{609}$ Matthews 1975, 345-351; Mathisen 1993, esp. 9-16; Durand y Leveau 2004, 225; Wickham 2005, 6972.

${ }^{610}$ Véase infra.

${ }^{611}$ Salv., Ad Eccl., 1.18. 
propiedades que su familia tenía allí y puso otras en arrendamiento, lo que le permitió al menos temporalmente- afrontar los gastos que le imponía su status ${ }^{612}$. Sidonio Apolinar, por su parte, ha dejado testimonio de la existencia de villae con espacios para el ocio al estilo tradicional ${ }^{613}$ y de otras en las que se habían construido defensas (el burgus de Poncio Leoncio, en Aquitania) ${ }^{614}$. Son numerosas sus referencias generales a tierras de la aristocracia ${ }^{615}$.

Otras grandes propiedades estaban en manos de las iglesias. Nos han llegado escritos reclamando la donación de bienes por parte de los feligreses ${ }^{616}$ y de aquellos que pretendían ingresar en la institución eclesiástica ${ }^{617}$. Muchos aristócratas cedieron propiedades a la Iglesia antes de ingresar a monasterios o de inclinarse por la vida ascética $^{618}$ o como un acto piadoso ${ }^{619}$. No obstante, desde el punto de vista económico, no parece haber existido diferencias sustanciales entre estas y las de la elite laica ${ }^{620}$.

John Percival ha sugerido que las villae que pervivieron en la región lo hicieron en las dos formas sugeridas por Sidonio. Sin embargo, esto no debe opacar el hecho de que muchas otras fueron abandonadas. El autor se apoya en este sentido en información arqueológica que evidencia la reutilización de villae con objetivos diferentes: refugios temporales ocupados por pequeños grupos de personas; asentamientos de individuos que trabajaban tierras cercanas, que habrían comenzado a construir casas alrededor de sus ruinas dando origen a suertes de aldeas; cementerios, con la eventual construcción

\footnotetext{
${ }^{612}$ Paul. Pell., Euch., 530-538: “verum exigui iactura laboris / suasit et in vacuum culturae impendere curam / vix plena exesi per iugera quattuor agri / et fundare domun summa in crepidine saxi, / ne quid de spatio terrae minuisse viderer. / Porro autem expensas, vitae quas posceret usus, conductis studui ex agris sperare paratas, / donec plena magis servis mansit domus et dum / maiores melior vires mihi praebuit aetas".

${ }^{613}$ Sid., Ep., 2.2, 2.9 y 8.4. Para Sidonio los veranos debían dedicarse al ocio en el campo (Ep., 2.2).

${ }^{614}$ Sid., Carm., 22 (en Aquitania). También sabemos que estaba fortificada una propiedad del prefecto Dáradano, en Narbonense II, en los comienzos del siglo V (PLRE, 2, 347).

${ }^{615}$ Sid., Ep., 1.6, 2.1, 2.9, 2.12, 2.13, 2.14, 3.1, 3.5, 4.8, 4.18, 4.21, 5.11, 5.20, 8.9 y 9.6. Existe acuerdo en que la descripción de la primera está inspirada en Plin., Ep., 2.17 y 5.6. De cualquier forma, esto no quita que existiesen este tipo de villae, como atestigua el registro arqueológico (Zadora-Rio 2009, 79). Para la discusión en torno al grado de crédito que debe otorgarse a estas descripciones de Sidonio, véase Bowes y Gutteridge 2005, 418-419.

${ }^{616}$ Salv., Ad Eccl., passim; Salv., Ep., 9.11; Paul. Nol., Ep., 39

${ }^{617}$ Iohan. Cass., Inst., 1.3; Salv., De gub. Dei, 3.3.14-15; Salv., Ad Eccl., 2.4.14 y 2.9.37-43; Klingshirn 1994, 75-82 (referencias a los escritos de Juliano Pomerio).

${ }^{618}$ Sobre la cuestión en general para el mundo occidental del periodo, ver Nouailhat 1988, 95-98. Para la Galia, hay casos concretos en Sulp. Sev., V. Mart., 25.4 (sobre Paulino de Pela, aquitano); Hil. Arel., V. Hon., 2.11; Finn 2006, 90-91 (referencia a la Vita Hilarii). El monasterio de Lérins administraba los bienes legados por sus hermanos (Hil. Arel., V. Hon., 4.20).

${ }^{619}$ Sid., Ep., 3.1.2-3.

${ }^{620}$ Giardina 2007, 768; Wickham 2011, 223.
} 
de una iglesia ${ }^{621}$. Estudios posteriores han revelado que en la región provenzal se produjo en los siglos IV y $\mathrm{V}$ una concentración de la población alrededor de unidades más importantes que en los periodos previos y que el número de villae disminuyó allí y en Languedoc entre los siglos III y V, pero que no desaparecieron ${ }^{622}$.

Esta información brindada por la arqueología no es fácil de interpretar. Desconocemos si los miembros de las familias que reutilizaban los espacios edilicios de las antiguas villae residenciales eran libres o no, o si estaban sujetos al pago de renta a los eventuales propietarios de esas tierras. No obstante, otras evidencias materiales testimonian la fuerte presencia de sectores aristocráticos en la región que nos ocupa en el periodo tardo-romano: epitafios, mausoleos, sarcófagos, sitios funerarios $\mathrm{y}$ cultuales $^{623}$. En suma, los datos arqueológicos parecen avalar el proceso de concentración de la propiedad de la tierra durante los siglos IV y V que sugieren las fuentes escritas ${ }^{624}$.

\section{Relaciones de explotación}

Ahora bien, ¿en qué forma las aristocracias explotaban sus propiedades? Podemos esbozar aquí brevemente un estado de la cuestión acerca de la vieja discusión sobre el fin de la esclavitud y el "colonato", aunque ya hemos visto en el primer capítulo de este trabajo la opinión de algunos historiadores al respecto. Hasta hace al menos unos treinta años, estuvo extendida en el mundo académico la idea de que el occidente romano había sido una sociedad esclavista hasta la crisis del siglo III y que $a$ posteriori de esa fecha, por la razón que se adujese, había comenzado a imperar la explotación de campesinos semi-libres (así se entendía el llamado “colonato"). Podemos nombrar a Perry Anderson y a M. I. Finley como exponentes de distinto cuño de esta tesis, si bien este último reconocía tanto que el esclavismo no había sido hegemónico en todo occidente como que los esclavos no habían desaparecido luego del siglo IV ${ }^{625}$.

Dejando a un lado la cuestión de en qué medida puede considerarse la sociedad romana tardo-republicana y alto imperial como "esclavista" (la idea está siendo revisada

\footnotetext{
${ }^{621}$ Percival 1992.

${ }^{622}$ Carru y otros. 2001; Trément 2001.

${ }^{623}$ Trément 2001, 286-287.

${ }^{624}$ Ripoll y Arce 2001, 44.

${ }^{625}$ Anderson [1974]; Finley 1982, 160-194.
} 
de forma convincente incluso para la Italia de los siglos II a. C. a II d. C. ${ }^{626}$ ), la tesis de la decadencia del esclavismo comenzó a ponerse en duda hace ya varios años. Hemos hecho referencia previamente a los historiadores etiquetados generalmente como "fiscalistas", que plantearon, grosso modo, la pervivencia de las estructuras sociales y políticas antiguas hasta aproximadamente el año 1000, pero incluso podríamos retrotraernos a un artículo de Marc Bloch editado post-mortem en el que se daba cuenta de la ingente presencia de servi en la documentación temprano medieval, que en su opinión no eran otra cosa que esclavos. Asimismo, el historiador francés destacaba la importancia de su explotación como mano de obra rural ${ }^{627}$. Décadas después, Pierre Bonnassie dedicó una comunicación académica al análisis de la "supervivencia y extinción del régimen esclavista" entre los siglos IV y XI en la que propuso que incluso había habido un recrudecimiento en el número de servi en occidente entre los siglos $\mathrm{V}$ y VII ${ }^{628}$. En años recientes tendió a aceptarse la idea de que, en mayor o menor grado, una parte importante de la población del mundo latino de las primeras centurias medievales tenía status servil ${ }^{629}$, aunque a partir de la publicación de Framing the Early Middle Ages la postura minimalista (ya no "decadentista") ha vuelto a ganar terreno ${ }^{630}$. Un problema distinto, sobre el que volveremos, es el del rol de esos esclavos en el proceso productivo.

Una discusión íntimamente relacionada a la del final de la esclavitud es la del "colonato". La historiografía consideró tradicionalmente al colonus tardo-imperial como un campesino arrendatario que había ido perdiendo progresivamente sus derechos hasta convertirse en un tenente semi-libre ${ }^{631}$. M. I. Finley conectó de hecho ambos desarrollos en el último capítulo de Esclavitud antigua e ideología moderna, en el que se analiza la

\footnotetext{
${ }^{626}$ García Mac Gaw 2006 y en prensa. Esto invita a revisar el viejo tópico de que hacia los siglos II-III d. C. se había producido una transición de la explotación intensiva de esclavos a la de terrazgueros (servi quasi coloni). No obstante, la idea de la existencia de un "modo de producción esclavista" sigue siendo sostenida (e. g. Giardina 2007, 755-757).

${ }^{627}$ Bloch [1947].

${ }^{628}$ Bonnassie 1991.

${ }^{629}$ Prácticamente no hay obras generales recientes sobre la esclavitud en la temprana Edad Media. Bondue (2010) profundiza poco en las fuentes, aunque es útil como material de consulta. Para esto último es fundamental Verlinden (1955 y 1977). Véase además Davies 1996 y las referencias a trabajos sobre áreas específicas en Harper 2011, 162.

630 Wickham 2005, 258-302. Harper $(2011,499-504)$ parte del planteo del primero de que aproximadamente entre los años 400 y 700 dominó el modo de producción campesino en Europa occidental (aunque sabemos que Wickham matiza esto) para proponer que los esclavos y sus propietarios fueron crecientemente excepcionales -"marginales"- en el periodo analizado.

${ }^{631}$ Jones [1958]; Whittaker y Garnsey 1998, 288-296. Más recientemente, Giardina 2007, 749-753; Banaji 2011, 121-124.
} 
transformación de las relaciones de explotación en el mundo rural occidental de los siglos IV-V. Allí propuso que la lenta erosión de los derechos y la progresiva pérdida de la propiedad de la tierra habían dejado al campesinado romano a merced de la explotación de los potentes. La esclavitud, que se había expandido a causa de la incapacidad previa de estos sectores de avanzar sobre sus conciudadanos más humildes, se había vuelto ahora innecesaria ${ }^{632}$.

Esta interpretación acerca del colonato fue seriamente cuestionada hace tres décadas por Jean-Michel Carrié. En su opinión, las leyes sobre coloni emitidas desde Constantino en adelante y conservadas en el Codex Theodosianus y el Codex Justinianus tenían como objetivo fijar una serie de derechos y deberes de estos hacia el Estado. En este punto, la postura no era necesariamente novedosa, puesto que A. H. M. Jones también había destacado en su tratamiento del problema esta cuestión (en su opinión las leyes habían indirectamente beneficiado a los propietarios ${ }^{633}$ ). Pero a diferencia de este, Carrié consideró que esas medidas, y en particular la adscripición a las propiedades en las que los coloni estaban censados ${ }^{634}$, no tuvieron consecuencias en el vínculo legal entre ellos y los titulares de esas tierras. No sostuvo que los coloni fueran arrendatarios libres; simplemente que las relaciones sociales de producción estaban, en todo caso, sujetas a otra dinámica de fuerzas, independiente de la relación de los actores con el Estado ${ }^{635}$.

El artículo de Carrié reavivó la discusión sobre la cuestión; las contribuciones a favor y en contra se han sucedido en las últimas tres décadas ${ }^{636}$. Wickham ha planteado recientemente que al analizar el problema muchos historiadores parten del presupuesto de que los códigos son recopilaciones exhaustivas de las leyes existentes y que estas eran habitualmente aplicadas. En su opinión hay información suficiente para poner en duda que las normas fueran conocidas por un espectro amplio de la población e incluso cuando lo eran, que fuesen puestas en vigor si se oponían a intereses de personajes con poder $^{637}$. Por otro lado, las leyes presumen una homogeneidad social que no se condice con lo que se sabe de algunas áreas concretas, como por ejemplo Egipto. Finalmente,

\footnotetext{
${ }^{632}$ Finley 1982, 160-194.

${ }^{633}$ Siguiendo lo registrado en C. J., 11.51 .1 (año 386).

${ }^{634}$ C. Th., 5.17.1 (año 332), C. J., 11.68.3 (año 364), 11.53 .1 (año 371) y 11.52 .1 (años 392-395).

${ }^{635}$ Carrié 1982 y 1983 . Véase también Carrié y Rousselle 1999, 607-614 y 680-686.

${ }^{636}$ Véase las bibliografía citada en Wickham 2005, 522, n. 6.

${ }^{637}$ Harries $(1999,77-98)$ sostiene que muchas leyes eran emitidas en respuesta a demandas de particulares, para ser aplicadas por particulares. Pero las normas sobre coloni tenían un claro interés fiscal.
} 
propone que las normas hablan más de los valores imperiales y del imaginario de los legisladores que de las prácticas concretas. Así por ejemplo, el hecho de que los coloni llegaran a ser considerados como "esclavos de la tierra" (servi terrae) ${ }^{638}$ y asemejados a prisioneros de guerra (quadam dedictii servitute) ${ }^{639}$ no habría tenido por qué reflejar una situación concreta o favorecer un cambio social en determinada dirección. En conclusión, Wickham otorga la derecha a Carrié e indica que para comprender las relaciones sociales rurales la mirada debe posarse en las relaciones de poder determinadas a nivel local ${ }^{640}$.

Creemos ahora que hay que atender parcialmente a los argumentos de estos historiadores ${ }^{641}$. Las relaciones sociales de producción debieron de variar a lo ancho del imperio y en el transcurso del tiempo en que las distintas normas se fueron sucediendo. Es importante tener en cuenta además que los coloni tampoco eran un grupo homogéneo desde el punto de vista legal; quienes tenían propiedades estaban censados en ellas y por lo tanto no estaban adscriptos a las tierras que trabajaban como tenentes ${ }^{642}$. Ello implica que lo que planteamos con respecto a la región que nos incumbe no necesariamente se aplica a otras. No obstante, no se debe soslayar el hecho de que las leyes fueron una herramienta beneficiosa en manos de la aristocracia; Wickham reconoce esto ${ }^{643}$. Los coloni -aunque no todos- tenían derechos básicos, por ejemplo a la propiedad ${ }^{644}$ y al

\footnotetext{
${ }^{638}$ C. J., 11.52 .1 (399): "[1] Et ne forte colonis tributariae sortis nexibus absolutis vagandi et quo libuerit recedendi facultas permissa videatur, ipsi quidem originario iure teneantur, et licet condicione videantur ingenui, servi tamen terrae ipsius cui nati sunt aestimentur nec recedendi quo velint aut permutandi loca habeant facultatem, sed possessor eorum iure utatur et patroni sollicitudine et domini potestate; [2] Si quis vero alienum colonum suscipiendum retinendumve crediderit, duas auri libras ie cogatur exsolvere, cuius agros transfuga cultore vacuaverit, ita ut eundem cum omni peculio suo et agnatione restituat".

${ }^{639}$ C. J., 11.50 .2 (396): "Coloni censibus dumtaxat adscripti, sicuti ab his liberi sunt, quibus eos tributa subiectos non faciunt, ita his, quibus annuis functionibus et debito condicionis obnoxii sunt, paene est ut quadam servitute dediti videantur. [1] Quo minus est ferendum, ut eos audeant lite pulsare, a quibus ipsos utpote a dominis una cum possessionibus distrahi posse dubium non est. [2] Quam de cetero licentiam submovemus, ne quis audeat domini in iudicio nomen lacessere, et cuius ipsi sunt, eiusdem omnia sua esse cognoscant. [3] Cum enim saepissime decretum sit, ne quid de peculio suo cuiquam colonorum ignorante domino praedii aut vendere aut alio modo alienare liceret, quemadmodum contra eius personam aequo poterit consistere iure, quem nec propria quidem leges sui iuris habere voluerunt et adquirendi tantum, non etiam transferendi potestate permissa, domino et adquirere et habere voluerunt? [4] Sed ut in causis civilibus huiusmodi hominum generi adversus dominos vel patronos et aditum intercludimus et vocem negamus exceptis superexactionibus, in quibus retro principes facultatem eis super hoc interpellandi praebuerunt, ita in criminum accusatione quae publica est non adimitur eis propter suam suorumque iniuriam experiendi licentia".

${ }^{640}$ Wickham 2005, 522-524.

${ }^{641}$ Corregimos así lo sostenido en Sarachu 2009.

${ }^{642}$ Carrié y Rousselle 1999, 613. Jones ([1958], 330) sugiere que el número de adscripti debió incluso de descender con el tiempo.

${ }^{643}$ Wickham 2005, 524-525.

${ }^{644}$ C. Th., 11. 24.1 (año 360).
} 
matrimonio $^{645}$. Por otro lado, como ha planteado Andrea Giardina recientemente, a diferencia de ciertas personas que estaban vinculadas legalmente a determinadas ocupaciones o profesiones (como los curiales, los transportistas, los hijos de veteranos), las ataduras de los colonos no eran con la comunidad en general sino con un terrateniente en particular, en una relación por definición asimétrica ${ }^{646}$. En última instancia, la capacidad para ejercer la dominación a nivel local dependía de un contexto social más amplio y de un poder público que lo apoyara. Esto corría tanto para el poder de los propietarios sobre los coloni como para el de los amos frente a los esclavos.

Es posible ahora abordar el problema de la forma en que esclavos y coloni eran explotados. Uno de los resultados más importantes de los estudios arqueológicos recientes ha sido el de hacer visible la enorme cantidad de pequeñas granjas que existieron en el mundo rural romano alto y bajo imperial. Las villae explotadas por grupos de esclavos encadenados no fueron dominantes en el campo y el campesinado libre y los granjeros tenentes deben de haber sido comunes en muchas áreas ${ }^{647}$. Pero es prácticamente imposible identificar a partir de los restos materiales el estatuto jurídico de los ocupantes de una tierra y, en el caso de los tenentes e incluso de los esclavos, desentrañar la naturaleza de su relación con el propietario legal de la misma; para ello sigue siendo fundamental la evidencia escrita ${ }^{648}$. Contamos con algunos testimonios específicos para el periodo, como la ya citada referencia de Paulino de Pella al arriendo de sus tierras o la solicitud de Sidonio al obispo Censorio de que condonase el pago de la renta de una propiedad de su diócesis en la que un diácono se había instalado ${ }^{649}$. Si nos apoyamos en documentación tardía, parecería que esta práctica fue la más común en

\footnotetext{
${ }^{645}$ C. J., 11.68 .4 (año 367).

${ }^{646}$ Giardina $2007,751$.

${ }^{647}$ Dyson 2003, 40-46. Dice el autor en p. 46: "The emphasis in most [archaological] survey has been on settlements and residential units. They have demonstrated that most of the Roman countryside supported diverse settlement types. While survey achaeology does not allow us to reconstruct precise social and economic structures, some generalizations cab be made from the evidence. Slave-based villas certainly existed in large numbers, but the chain-gang did not dominate the Roma countryside. Both a free peasantry and tenant farmers must have been common in many areas. Clearly much of the Roman countryside was tied into a market economy, with all the positives and negatives that entailed".

${ }_{648}^{64}$ Sodini 2003, 26-27.

${ }^{649}$ Sid., Ep., 6.10 (473): "Gerulum litterarum levitici ordinis honestat officium . hic cum familia sua depraedationis Gothicae turbinem vitans in territorium vestrum delatus est ipso, ut sic dixerim, pondere fugae; ubi in re ecelesiae, cui sanctitas tua praesidet, parvam sementem semiconfecto caespiti advena ieiunus iniecit, cuius ex solido colligendae fieri sibi copiam exorat. Quem si domesticis fidei deputata humanitate foveatis, id est, ut debitum glaebae canonem non petatur, tantum lucelli praestitum sibi computat (peregrini hominis ut census, sic animus angustus), ac si in patrio solo rusticaretur. Huic si legitimam, ut mos est, solutionem perexiguae segetis indulgeas, tamquam opipare viaticatus cum gratiarum actione remeabit. Per quem si me stilo solitae dignationis impertias, mihi fraternitatique istic sitae pagina tua veluti polo lapsa reputabitur. Memor nostri esse dignare, domine papa".
} 
las grandes propiedades del midi galo ${ }^{650}$. Sin embargo, la cuestión sigue generando controversias $^{651}$. A través de Sidonio sabemos de la existencia de administradores (actores) que explotaban tierras con viñedos y olivares ${ }^{652}$.

El asunto del empleo de esclavos en las propiedades rurales de la región analizada en esta tesis durante la época tardo-romana es particularmente espinoso. Kyle Harper indica que existió una extendida explotación de la mano de obra servil en el periodo 275-425 en las zonas más ricas de occidente como el norte de África, el norte de Italia y el sur de la Galia, pero que la documentación sobre el ámbito rural es escasa, particularmente para esta última ${ }^{653}$. Hasta hace algunas décadas, era común la opinión de que durante ese tiempo había dominado un tipo de mano de obra dependiente distinta, nominalmente libre ${ }^{654}$. Ross Samson criticó esta postura, planteando la hipótesis de que buena parte de las granjas campesinas debió de estar ocupada por esclavos $^{655}$. Sabemos, por ejemplo, que a fines del siglo IV la compra de no libres era accesible a miembros de la comunidad monacal de Martín de Tours ${ }^{656}$. La captura y comercialización continuó durante el siglo $\mathrm{V}$, avivada por los conflictos militares ${ }^{657}$. Salviano se refiere en numerosas ocasiones a los esclavos en su De gubernatione Dei, aunque prácticamente siempre en términos vagos y generalizadores, sin referencias a situaciones concretas, en el contexto de argumentaciones moralizantes. Menciona a amos que confiaban la administración o cuidado de bienes muebles a sus esclavos ${ }^{658} \mathrm{y}$ llama a evitar el servilismo de los domésticos ${ }^{659}$. Los concilios galos dan cuenta del

\footnotetext{
${ }^{650}$ Devroey 2003, 298.

651 Banaji sostiene que los terratenientes romanos nunca abandonaron la explotación directa de sus propiedades y que incluso legaron esta "tradición" a la aristocracia franca (Banaji 2011, 129-131, contra Wickham 2005, 268-283).

${ }^{652}$ Sid., Ep., 5.20 (461-467): "Praeterea tibi Arelate profecturo est venerabilis in itinere mater fratres amantes redamantisque patriae solum, ad quod et praeter occasionem voluptuose venitur; tum domus propria, cuius actorem, vineam messem olivetum, tectum quoque ipsum, vel dum praeterveharis, inspicere res commodi est. Quapropter, missus a nobis, et tibi pervenis; namque erit talis viae tuae causaeque nostrae condicio, ni fallor, atque opportunitas, ut pro beneficio civitati posse imputare quandocumque videaris, quod tuos videris". Posiblemente la propiedad referida en Sid., Ep., 4.21 también fuese explotada de un modo similar.

${ }^{653}$ Harper 2011, 187.

${ }^{654}$ Wightman 1978; Drinkwater 1983, 170 y ss.; MacMullen 1987.

${ }^{655}$ Samson 1989; 1992, 221-222.

${ }^{656}$ Sulp. Sev., Dial., 3.15.

${ }^{657}$ Samson 1992, 227. Véase Sid., Ep., 6.4.

${ }^{658}$ Salv., De gub. Dei, 3.2.7: "Sicut enim servi hominum divitum aut procuratores, quibus vel supellectiles copiosae vel cellaria opulenta creduntur, fideles absque dubio dici non queunt, si res sibi traditas devorarint: sic profecto etiam Christiani homines infideles sunt, si bona sibi a deo adsignata corruperint".

${ }^{659}$ Salv., De gub. Dei, 3.8.39: "Unde est illud etiam, quod in sequentibus ait dominus: si scandalizat te oculus tuus, erue eum, et si scandalizat te manus tua, abscide eam: expedit tibi ut pereat unum
} 
fenómeno de la manumisio in ecclesia, hecho que evidenciaría que la presencia de no libres en la Galia era relevante ${ }^{660}$. La mayoría de los datos más concretos con que contamos se refiere a esclavos vinculados al espacio doméstico o no precisan su ubicación u ocupación ${ }^{661}$, pero en algunos es inequívoca su pertenencia al mundo rural $^{662}$. Por otro lado, Paulino de Pella y la Crónica gala de 452 registran conflictos sociales en los que estuvieron involucrados servi provenientes probablemente de este ámbito $^{663}$. Estas informaciones - ciertamente fragmentarias- abonarían a la idea de una presencia importante de esclavos en la Galia meridional del periodo tardo-romano, incluso en el campo.

La documentación para estudiar a los coloni es aún más pobre. Las referencias concretas son aisladas, como la de Sidonio en la epístola 5.19. Las leyes remitidas específicamente a prefectos de la Galias confirman su presencia, pero debe tenerse en cuenta que la jurisdicción cuyo mandato tenían estos funcionarios incluía, además de la región homónima, Hispania, Britana, Germania y Mauritania Tingitana ${ }^{664}$. En este contexto, Salviano es uno de nuestros mejores testimonios. A continuación veremos que durante los años de mayor presión fiscal en la Galia muchos campesinos propietarios se vieron obligados a buscar protección contra los recaudadores en vecinos más poderosos. El precio a pagar era la pérdida de sus bienes y el corolario del proceso su conversión en tenentes. Esto daría la pauta de que los coloni fueron relevantes en la Galia meridional en el periodo analizado.

De cualquier forma, nos interesa menos analizar el grado de diferenciación o acercamiento en cuanto al estatuto legal entre esclavos y coloni, que indagar en la forma en que eran explotados. Debería ser patente a esta altura que ello no resulta sencillo. Whittaker planteó hace algún tiempo que durante la época tardo-romana se produjo una progresiva transformación en las relaciones de dependencia rural consistente en una

membrorum tuorum, quam totum corpus tuum mittatur in gehennam. Si igitur iuxta dei verbum in gehennam scandalis trahimur, recte profecto, ut gehennam vitare possimus, etiam manibus nostris nos oculisque multamus, non quod membris suis quis privare se debeat, sed, quia tam necessariae nobis sunt quaedam domesticorum obsequiorum necessitudines, ut his quasi oculis in terdum aut manibus utamur, recte nobis praesentium ministeriorum officia subtrahimus, ne aeterni ignis tormenta patiamur: ubi enim de ministerio agitur et vita, rectius profecto Christiano est ministerio carere quam vita".

${ }^{660}$ Conc. Orange (441), c. 6; Conc. Agde (511), c. 29; Conc. Orléans (549), c. 7.

${ }^{661}$ Dial., 2.14, 3.3-4 y 3.14; V. Mart., 2, 17; Ep., 2; Paul. Pell., Euch., 207 y 537; Sid., Ep., 1.6., 3.9, 4.8, $4.12,4.18,4.24,5.19,6.5,7.2,8.11$ y 9.6 .

${ }^{662}$ Sulp. Sev., V. Mart., 8; Hil. Arel., V. Hon., 1.7; Sid., Ep., 4.9.

${ }^{663}$ Paul. Pell., Euch., 329-442; Chron. Gall. a. CCCCLI, 117 (año 435); Harper 2011, 279.

${ }^{664}$ C. J., 11.48 .6 (año 366) y 11.48 .7 (año 371) (véase con respecto al remitente de esta última ley Grey 2007, 168, n. 67); C. Th., 4.23.1 (año 400) y 12.19.2 (año 400). 
mayor capacidad de los señores para imponer servicios laborales a los campesinos, en un contexto de creciente debilitamiento de las autoridades centrales. Su tesis se asemeja a interpretaciones ya referidas, pero conviene traerla a colación en este punto pues se centra particularmente en el testimonio de Salviano. En su opinión, los campesinos propietarios perdieron progresivamente su tierra quedando sometidos a formas de dependencia personal que en definitiva dieron origen a la servidumbre medieval. Por otro lado, los esclavos se habrían asimilado a esa nueva clase sometida ${ }^{665}$. Goffart ha planteado ahora una crítica a esta interpretación mencionando entre otras cosas $-\mathrm{y}$ acertadamente- que el bajo imperio fue antes un periodo de afirmación del poder estatal central que de debilitamiento. Un importante mecanismo de caída en dependencia del campesinado propietario estaba íntimamente relacionado con el incremento de la presión fiscal, es decir, con el avance del Estado. Sin embargo, el autor ha propuesto en su lugar la idea de que los coloni habrían sido una suerte de arrendatarios acomodados, con ciertas restricciones en sus derechos producto de una serie de medidas fiscales, es cierto, pero que a su vez explotaban mano de obra dependiente (esclavos) ${ }^{666}$. No coincidimos con sus planteos. El propio Carrié ha sugerido hace algunos años que la Galia era una región con una fuerte subordinación de la mano de obra "libre", donde el "ius colonatus" no habría modificado las relaciones precedentes ${ }^{667}$. Por otro lado, aunque insiste en que las leyes no son idóneas para estudiar las relaciones de dependencia (privadas), admite que su contenido confirma los abusos de autoridad de los propietarios sobre sus coloni ${ }^{668}$. En base a esto y a la forma en que, como veremos, Salviano describe la situación de aquellos que se convertían en tenentes tras la pérdida de su tierra, resulta difícil no arribar a la conclusión de que la mayoría de los coloni debían de ser campesinos en un contexto económico cercano a la subsistencia, explotados tanto por los propietarios de las tierras que trabajaban como por el Estado.

Es imposible hacer una estimación numérica de la presencia de esclavos y coloni en el área rural de la Galia meridional. En base a lo desarrollado anteriormente, cabría argumentar que ambos tuvieron una presencia destacada en un periodo (hasta $c .450$ ) en el que existía un claro sometimiento de buena parte del campesinado a los sectores aristocráticos. Por otro lado, teniendo en cuenta lo anteriormente planteado en torno al

\footnotetext{
${ }^{665}$ Whittaker [1987], 111-114.

${ }^{666}$ Goffart 2009, 281-287.

${ }^{667}$ Sigue en este sentido la línea planteada por Wightman y Drinkwater (véase supra).

${ }^{668}$ Carrié y Rousselle 1999, 685-686.
} 
concepto de "clase estamental", podemos plantear ahora que, excepto en lo relativo al pago de impuestos, los coloni diferían poco de los esclavos; socioeconómicamente pertenecían a la misma clase social.

\section{El pequeño propietario}

Peter Garnsey y Charles Whittaker advierten sobre la frecuencia con que se olvida que entre los muy ricos y los tenentes había en el imperio una clase de granjeros libres propietarios de un lote de tierra que podía variar entre un tamaño medio -como podía ser el del curial de una ciudad modesta- y uno pequeño. No es de extrañar, sin embargo, que solo excepcionalmente aparezcan reflejados en los textos que nos han llegado, escritos principalmente por y para la aristocracia. La información arqueológica, por otra parte, tiene las limitaciones que ya hemos presentado. Si bien se han registrado gran número de sitios de tamaño medio en las provincias occidentales durante los siglos IV y V y se ha constatado una reducción de los de tamaño pequeño, no sabemos si estas tierras pertenecían a campesinos propietarios o a tenentes ${ }^{669}$.

A pesar de la fuerte concentración de la propiedad territorial en pocas manos, el campesinado propietario sobrevivió en la Galia meridional durante todo el periodo tardo-romano. En algunas provincias existía población rural que no estaba registrada en las tierras que trabajaban como arrendatarios. La existencia de estos coloni no adscriptos -que se extendía a otras provincias- evidencia indirectamente la presencia de campesinos propietarios. En este caso se trataba con toda probabilidad de unidades demasiado pequeñas, pues el titular debía de arrendar otra parcela para poder mantener a su familia ${ }^{670}$. Otro indicio es la presencia de jornaleros en las explotaciones de los grandes terratenientes en los periodos de mayor intensidad laboral del año agrícola ${ }^{671}$. Finalmente, también resulta de suma importancia para constatar la existencia de campesinos propietarios el testimonio de Salviano de Marsella. El sacerdote denuncia los mecanismos por los cuales quienes vivían en agelli, resculae, habitatiunculae perdían sus tierras a manos de los potentes o huían con los bárbaros ${ }^{672}$. Difícilmente

\footnotetext{
${ }^{669}$ Whittaker y Garnsey 1998, 297. Véase también Garnsey 1998, 98-104.

${ }^{670}$ C. J., 11.48 .6 (año 366); Jones 1964, 797-798.

${ }^{671}$ Jones 1964, 794-795.

${ }^{672}$ Salv., De gub. Dei., 5.8.37-38: “Et miramur, si non vincuntur a nostris partibus Gothi, cum malint apud eos esse quam apud nos Romani? Itaque non solum transfugere ab eis ad nos fratres nostri omnino nolunt, sed ut ad eos confugiant, nos relinquunt. Et quidem mirari possim quod hoc non omnes omnino
} 
podamos entender otra cosa que pequeñas propiedades a partir de la terminología empleada.

Por otra parte, una cuestión fundamental desde nuestra óptica es la de distinguir al campesino propietario del bajo imperio del campesino independiente que comienza a emerger antes de la caída de Roma y que se consolida durante el primer siglo medieval. Entre ambos pudo existir una continuidad genealógica - es decir, familias que retuvieron su alodio en el transcurso del periodo analizado-, pero solo podemos conjeturar la magnitud del caso. De cualquier manera, la diferencia fundamental es que a pesar de ser libre y propietario, el primero se encontraba sometido a una muy dura explotación por parte del poder público, mientras que, en un contexto de debilidad estatal y de las aristocracias, el segundo no estaba sujeto al pago de rentas ni impuestos o bien la cuantía de estos tenía un carácter prácticamente simbólico. Esto ha sido debidamente analizado en el capítulo previo. Como veremos más adelante, no pretendemos que todos los campesinos de mediados del siglo VI fueran independientes, pero sí es probable que lo haya sido una importante mayoría.

\section{PATRONAZGO Y PATROCINIO}

Antes de comenzar con el desarrollo del tema de este apartado es necesaria una precisión semántica. En nuestra opinión, el patrocinium que describe Salviano en su De gubernatione difiere del clientelismo rural preexistente en el hecho de que mientras que este último es un vínculo de relativa reciprocidad entre desiguales que existe al margen del papel del Estado, el primero es una relación que conduce a la caída en dependencia y en la que el poder público juega un papel decisivo. Con el propósito de hacer más clara la exposición entenderemos entonces por "patrocinium" o "patrocinio" el fenómeno novedoso que presenta el sacerdote de Marsella, mientras que "clientelismo" o "patronazgo" referirá a las relaciones clientelísticas preexistentes o "tradicionales".

Lo expuesto en el capítulo previo acerca de la presión fiscal que sufrió la población a posteriori de las invasiones germánicas impone que se atienda a la

facerent tributarii pauperes et egestuosi, nisi quod una tantum causa est quare non faciunt, quia transferre illuc resculas atque habitatiunculas suas familiasque non possunt. Nam cum plerique eorum agellos ac tabernacula sua deserant ut vim exactionis evadant, quomodo non quae compelluntur deserere vellent, sed secum, si possibilitas pateretur, auferrent?". 
dimensión estatal a la hora de intentar comprender el fenómeno del patrocinium rural que describe Salviano en el De gubernatione Dei, su tratado moralizante. Podría considerarse que esto va de suyo, en tanto el propio presbítero vincula explícitamente la protección a la evasión fiscal. Sin embargo, no todos los historiadores que han analizado el problema parecen haber considerado las implicancias profundas que la cuestión tuvo para la estructuración y la dinámica de los patrocinios. Algunos incluso parecen minimizar el rol que jugó el Estado tardo-romano como extractor de excedente en la aparición misma del fenómeno, enfatizando la continuidad de formas anteriores de patronazgo. Retomamos aquí algunos planteos ya publicados ${ }^{673}$.

Para Garnsey y Woolf, el patrocinium tardo-romano fue parte de un fenómeno de más larga duración, inscripto en una sociedad atravesada por relaciones clientelísticas. La novedad del periodo habría radicado en la aparición de una mayor competencia entre patronos dada por el surgimiento de un conflicto entre los curiales y los miembros activos o retirados de la burocracia central. Los pobres, entonces, habrían tenido la posibilidad de optar entre el patronazgo de unos o de otros. En este sentido, las fuentes evidenciarían un aumento de la oferta de patronos. Si bien esta tesis parte del discutible presupuesto de que los actores sociales de la Antigüedad -particularmente los campesinos- elegían libremente las relaciones que establecían entre ellos, de manera análoga a como los factores económicos interactúan en un mercado moderno, cabe decir que podría ser plausible para interpretar la denuncia que Libanio hace de la protección que jefes militares estaban haciendo sobre sus propios coloni en la Siria de fines del siglo $\mathrm{IV}^{674}$. Pero de ninguna forma es aceptable para entender el patronazgo rural de la Galia del siglo V. La idea de un aumento de la "oferta" de patronos y de la posibilidad de optar por unos o por otros, llevaría a pensar que los campesinos estaban en condiciones de negociar favorablemente los términos de la relación. Esto no se condice para nada con el testimonio de Salviano y con el contexto histórico y desestima además la importancia que tuvo el cobro de impuestos como mecanismo opresor sobre el campesinado $^{675}$.

Las formas anteriores de patronazgo serían consustanciales con la definición corriente de clientelismo que dan las ciencias sociales: un vínculo relativamente recíproco y voluntario entre personas de riqueza, poder o status desiguales. En este tipo

\footnotetext{
${ }^{673}$ Sarachu 2011 b.

${ }^{674}$ Véase Carrié 1976 para el patronazgo oriental.

${ }^{675}$ Garnsey y Wolf 1989.
} 
de relación, el patrono se encuentra en posición de poder suministrar bienes o servicios que el cliente necesita, pero no de imponer unilateralmente su voluntad ${ }^{676}$. La lógica es la del don y contra-don, por la cual las partes deben llegar a un acuerdo que mantenga un intercambio relativamente igualitario. Por supuesto, la dinámica social no impide que la relación se desvirtúe en una de explotación si el patrono logra imponerse por sobre el cliente $^{677}$. James Scott ha propuesto situar el fenómeno estudiado dentro de un continuиm que iría desde los lazos personales entre iguales hasta los vínculos puramente coercitivos $^{678}$. En nuestra opinión, esta definición conduce a restar importancia al salto cualitativo que implica el paso de una diferenciación de status a una de clase -permitida por la apropiación de excedente-, confundiendo clientelismo y explotación en un mismo vínculo con tantos matices como casos puedan existir.

Ciertamente, y a pesar de que sea difícil su rastreo para la Galia alto imperial, puede sostenerse la hipótesis de cierto grado de continuidad en la presencia de lazos de patronazgo tradicionales entre sectores campesinos más acomodados y aristócratas ${ }^{679}$. Los patrocinios de los que habla Salviano constituyen, en cambio, un fenómeno distinto y con otra dinámica; un nuevo proceso en el que el estado tributario jugó un rol central.

Cabe preguntarse, entonces, qué es lo que se dice concretamente en el De gubernatione Dei acerca de esos patrocinia. Salviano señala que muchos pobres, presionados por las cargas fiscales, no tenían otra opción que ponerse bajo la protección y el cuidado de los poderosos. Por medio de este expediente, pasaban a sus jurisdicciones y se convertían en sus cautivos ${ }^{680}$. Se trataba indudablemente de pequeños campesinos propietarios, por un lado, y de miembros de la aristocracia laica,

\footnotetext{
${ }^{676}$ Véase $e$. g. Gellner 1985 y Wolf 1980.

${ }^{677}$ Garnsey 2003, 90.

${ }^{678}$ Scott 1985.

${ }^{679} \mathrm{La}$ continuidad de las relaciones de patronazgo en todo el periodo romano en la Galia es sostenida con diferentes matices por Drinkwater (1989) y Van Dam (1985, 25-56). Para este último, los vínculos de patronazgo entre los líderes locales y los sectores populares fueron una constante que incluso se remontaría al periodo pre-romano. Algo similar plantea Drinkwater, que sin embargo critica la idea de Van Dam de una continuidad lineal de los liderazgos aristocráticos, poniendo énfasis, en cambio, en las rupturas marcadas por la desaparición de determinadas familias y la emergencia de otras. Finalmente, mientras Van Dam considera que Salviano no hace referencia a ningún fenómeno nuevo -sino que, en todo caso, critica a algunos aristócratas por no brindar la seguridad debida a sus protegidos-, Drinkwater sostiene que hubo un cambio hacia el bajo imperio en el sentido de una intensificación del fenómeno del patronazgo.

${ }^{680}$ Salv., De gub. Dei, 5.8.38: "Nam cum plerique eorum agellos ac tabernacula sua deserant, ut vim exactionis evadant, quomodo non quae compelluntur de serere vellent, sed secum, si possibilitas pateretur, auferrent? Ergo quia hoc non ualent quod forte mallent, faciunt quod unum ualent: tradunt se ad tuendum protegendumque maioribus, dediticios se diuitum faciunt et quasi in ius eorum dicionemque transcendunt".
} 
por el otro ${ }^{681}$. Este arreglo, dice Salviano, consistía en la cesión por parte de los primeros del derecho a la herencia de sus propiedades en favor de los patronos, a cambio de la promesa de un auxilio que muchas veces no se cumplía ${ }^{682}$. El cuadro final era el del incremento de las propiedades de los protectores y la mendicidad de los protegidos, muchos de los cuales debían continuar pagando impuestos como si todavía conservasen sus propiedades ${ }^{683}$.

Es necesario hacer un paréntesis para señalar que esto no supuso ni la desaparición del pequeño campesinado propietario, ni el colapso del sistema fiscal en la Galia, toda vez que Salviano nos relata un proceso en plena vigencia. Como planteamos en el capítulo precedente, el cobro de impuestos parece haber continuado funcionando hasta los últimos años de gobierno imperial en la región, e incluso con posterioridad, si bien mucho más débilmente. Hemos dejado patente nuestro alejamiento de quienes ven una decadencia inexorable del aparato estatal casi desde las reformas de Diocleciano, advirtiendo al mismo tiempo que a partir de la generación anterior a la caída del imperio el sistema fiscal encontró dificultades cada vez mayores para funcionar.

Salviano también nos informa acerca del carácter de la relación que se establecía a través de estos patrocinia. El pasaje inmediato al último referido resulta de sumo interés para la materia. El autor dice allí que solo algunos de los protegidos se convertían en coloni, los que eran muy precavidos o a quienes la necesidad había vuelto precavidos ${ }^{684}$. Pero esta situación aparentemente ventajosa contrasta con lo que plantea a continuación, cuando sugiere que esos mismos perdían sus domicilios y heredades a causa de las invasiones o de los exactores (es decir, por los recaudadores de impuestos);

\footnotetext{
${ }^{681}$ Véase supra, la referencia a los términos utilizados por Salviano para denominar las propiedades de quienes se ponían en protección. Que se trataba de la aristocracia laica queda patente en su reiterada utilización del vocablo potente.

${ }^{682}$ Salv., De gub. Dei, 5.8.39: “Omnes enim hi qui defendi uidentur, defensoribus suis omnem fere substantiam suam prius quam defendantur addicunt; ac sic, ut patres habeant defensionem, perdunt filii hereditatem: tuitio parentum mendicitate pignorum comparatur".

${ }^{683}$ Salv., De gub. Dei, 5.8.42-43: “quod plerique pauperculorum atque miserorum spoliati resculis suis et exterminati agellis suis cum rem amiserint, amissarum tamen rerum tributa patiuntur! cum possessio ab his recesserit, capitatio non recedit! proprietatibus carent et uectigalibus obruuntur! [43] Quis aestimare hoc malum possit? Rebus eorum incubant peruasores et tributa miseri pro peruasoribus soluunt! Post mortem patris nati obsequiis iuris sui agellos non habent et agrorum muniis enecantur. Ac per hoc quid aliud sceleribus tantis agitur, nisi ut qui priuata peruasione nudati sunt publica adflictione moriantur, et quibus rem depraedatio tulit, uitam tollat exactio?".

${ }^{684}$ Salv., De gub. Dei, 5.8.43: "Itaque nonnulli eorum de quibus loquimur, qui aut consultiores sunt aut quos consultos necessitas fecit, cum domicilia atque agellos suos aut peruasionibus perdunt aut fugati ab exactoribus deserunt, quia tenere non possunt, fundos maiorum expetunt et coloni diuitum fiunt". Modificamos ligeramente lo sostenido en Sarachu 2009 donde de manera terminante se planteaba que el derrotero inexorable de los "protegidos" había sido convertirse en coloni sin propiedades.
} 
que huían a los castella $^{685}$ para someterse al vil yugo de la servidumbre, siendo recibidos como extraños en las tierras de los ricos y tomados como parte de su propiedad. Salviano plantea incluso que al hacerlo se transformaban en sus esclavos, de la misma forma en que Circe había convertido a los hombres en bestias ${ }^{686}$. Para Whittaker, como hemos dicho, Salviano estaría hablándonos en este pasaje de un tipo particular de colonato, de una dependencia ligada más al servicio personal que a la tierra y por el que se pagaba un tributo ${ }^{687}$. En verdad, esta interpretación podría ser apropiada para pensar el derrotero de los segmentos campesinos más desesperados, pero no para aquellos que, según el presbítero, habían sido "precavidos".

La caída en servidumbre era evidentemente un riesgo latente para los humildes. Antes de continuar con el análisis centrado en el testimonio de Salviano es pertinente traer a colación una carta escrita por Sidonio en torno al 472. Se refiere en ella a un nativo de Clermont, nacido en una familia de libres que había ocupado cargos eclesiásticos, sin pretensiones de encumbrarse socialmente, pero que tampoco corría riesgos de caer en servidumbre. Esto último es de particular interés. Claramente la familia a la que se refiere Sidonio podría ser ubicada dentro de la baja aristocracia o de los sectores libres "medios". Pero el hecho de que indique expresamente que su condición jurídica no corría riesgo daría la pauta de que esto era una posibilidad latente. Si era este el caso para la baja aristocracia, tanto más lo sería para libres menos acomodados, como era el caso de los campesinos ${ }^{688}$.

\footnotetext{
${ }^{685}$ Recuérdese que muchas de las propiedades rurales de los grandes terratenientes se habían fortificado para el periodo analizado.

${ }^{686}$ Salv., De gub. Dei, 5.8.44-5.9.45: "Ac sicut solent aut hi qui hostium terrore compulsi ad castella se conferunt, aut hi qui perdito ingenuae incolumitatis statu ad asylum aliquod desperatione confugiunt, ita et isti, quia tueri amplius uel sedem uel dignitatem suorum natalium non queunt, iugo se inquilinae abiectionis addicunt, in hanc necessitatem redacti ut extorres non facultatis tantum, sed etiam condicionis suae atque exulantes non a rebus tantum suis, sed etiam a se ipsis ac perdentes secum omnia sua et rerum proprietate careant et ius libertatis amittant. [45] Et quidem, quia ita infelix necessitas cogit, ferenda utcumque erat extrema haec sors eorum, si non esset aliquid extremius. Illud grauius et acerbius quod additur huic malo saeuius malum. Nam suscipiuntur ut aduenae, fiunt praeiudicio habitationis indigenae; et exemplo quondam illius maleficae praepotentis quae transferre homines in bestias dicebatur, ita et isti omnes qui intra fundos diuitum recipiuntur, quasi Circaei poculi transfiguratione mutantur. Nam quos suscipiunt ut extraneos et alienos, incipiunt habere quasi proprios; quos esse constat ingenuos, uertuntur in seruos".

${ }_{687}$ Whittaker [1987], 113 .

${ }^{688}$ Sid., Ep., 7.2: "Arverni huic patria; parentes natalibus non superbis sed absolutis, et sicut nihil illustre iactantes, ita nihil servile metuentes, contenti censu modico sed eodem vel sufficiente vel libero; militia illis in clericali potius quam in Palatino decursa comitatu. Pater istius granditer frugi et liberis parum liberalis quique per nimiam parsimoniam iuveni filio plus prodesse quam placere maluerit. Quo relicto tunc puer iste vos petiit nimis expeditus, quod erat maximum conatibus primis impedimentum; nihil est enim viatico levi gravius".
} 
Regresemos al relato de Salviano. Acaso parte de aquellos que según el sacerdote se colocaban al servicio de un señor no fueran precisamente el tipo de campesinos desesperados por los impuestos. Miembros de la baja aristocracia pudieron haber recurrido a esta salida ante el riesgo de la caída en servidumbre que hemos comentado anteriormente ${ }^{689}$. Esto ayudaría a explicar lo que de otro modo sería un sinsentido por parte de Salviano ${ }^{690}$. Esos "algunos" (nonnulli) podrían no ser quienes se sometían a dependencia personal, sino campesinos relativamente acomodados que establecían relaciones de cierta reciprocidad con los patronos, mediante las cuales recibían protección contra los cobradores de impuestos a cambio de servicios deferenciales, de una prestación militar o bien del pago de una renta simbólica. Incluso lo que aparentaba ser una pérdida de la propiedad de la tierra podía ser nada menos que una maniobra legal para evadir al fisco ${ }^{691}$. Esto implica, por supuesto, que los terratenientes que ofrecían esta protección eran capaces de evadir impuestos mediante este tipo de fraudes. En este sentido podemos aceptar que la teoría de Goffart de los coloni como arrendatarios acomodados encierra una verdad parcial.

Tenemos otros indicios que apuntan a la existencia de una clientela más acomodada. Una esclava de Sidonio Apolinar había sido raptada por el hijo de la nodriza de un tal Prudencio. Aparentemente, este último no tenía la intención de

\footnotetext{
${ }^{689}$ Salviano (De gub. Dei, 5.5.21) incluía entre los desesperados que huían hacia los bárbaros a personas de ascendencia preclara y educación liberal. Véase la transcripción en n. 727.

${ }^{690}$ Contra la interpretación tradicional de que Salviano estaba siendo sarcástico en este pasaje, Cam Grey (2006, 179-182) sugiere que se trataría más bien de una desaprobación de ciertos procedimientos practicados por pequeños campesinos relativamente acomodados, basada en actitudes aristocráticas tradicionales hacia el trabajo banáusico y la dependencia personal. Esta lectura se encuadra dentro de la hipótesis de que el patrocinium rural del que se habla a lo largo del De gubernatione Dei se inscribía dentro de una serie de "estrategias" que los campesinos más o menos acomodados adoptaban con el fin de administrar el riesgo. En nuestra opinión, los pauperes de quienes habla Salviano eran en gran proporción -aunque no en su totalidad- pequeños campesinos en una situación de riesgo mucho más apremiante que la que supone Grey y que difícilmente les permitiera desplegar "estrategias" de acción.

${ }^{691}$ Grey (2006, 178-179), relaciona la práctica denunciada por Salviano con evidencias de fuentes del periodo que hablan de transferencia fraudulenta de propiedades con el objeto de escapar a las obligaciones impositivas (C. Th., 12.1.33, año 342: “Quoniam sublimitas tua suggessit multos declinantes obsequia machinari, ut privilegia rei privatae nostrae colonatus iure sectantes curialium nominationes declinent, sancimus, ut, quicumque ultra XXV iugera privato dominio possidens ampliorem ex re privata nostra iugerationis modum cultura et sollicitudine propria gubernaverit, omni privilegiorum vel originis vel cuiuslibet excusationis alterius frustratione submota curiali consortio vindicetur. Illo etiam curiae similiter deputando, qui minus quidem quam XXV iugerorum proprietatem habeat, ex rebus vero nostris vel parvum vel minorem iugerationis modum studio cultionis exercet. Ita ut omni fraude submota si qui venditione simulata praescriptas lege minuat facultates, omne, quod simulata venditione ad alium transtulit, fisci nostri viribus vindicetur. Quam poenam illi etiam sustinebunt, qui captiosa supplicatione delata speciale rescriptum in fraudem sanctionis extorserint"). De todas maneras, la existencia de este tipo de ardides no va en desmedro de la efectiva transferencia de propiedad en buena parte de los casos que involucraban a campesinos desesperados.
} 
prohibir la relación de concubinato que había surgido entre el perpetrador y su víctima; de hecho había pedido a Sidonio que perdonase la ofensa cometida. El auvernio le escribe entonces para acceder al requerimiento de Prudencio, a condición de que este eleve el status original de su dependiente -descripto también como tributarius e inquilinus - al de cliente, dejando así de ser su dominus para pasar a ser su patronus; de esta forma el vínculo de la pareja quedaría institucionalizado, pues Sidonio se comprometía a liberar a su esclava ${ }^{692}$. La carta -a la que hemos hecho referencia más arriba- revela dos cuestiones significativas: en primer lugar, que entre Prudencio y su colonus existía una relación de dependencia personal, puesta en evidencia por la propia utilización del término dominus (amo), pero también por el hecho de que solo a este correspondiera elevar el status de su colonus; y en segundo lugar, que la relación patrono-cliente era considerada de una naturaleza claramente distinta de la anterior, pues un patronus no podía ser de ningún modo dominus de un cliens. Cabe además una última reflexión: si el colonus fuese un arrendatario acomodado que incluso podía explotar esclavos, como pretende Goffart, ¿cómo explicar una socialización cercana a una esclava e incluso una unión matrimonial?

De manera similar, en la descripción que realiza del estilo de vida de un tal Vectio al que ha visitado recientemente, Sidonio diferencia claramente lo que son sus servi - de la ciudad y de sus tierras- de lo que son los huéspedes y clientes que se sientan a su mesa. En este último lugar, dice, reina la humanitas y la sobriedad ${ }^{693}$. Excluyendo a los huéspedes, resulta claro que el convite vincula sujetos de status desigual. Aunque no se nos indique expresamente en qué consistía el servicio de dichos clientes -ni tampoco el del patrono-, la misma descripción de Sidonio parece enseñarnos un acto de deferencia: al acudir a la mesa de su patrono, los clientes

\footnotetext{
${ }^{692}$ Sid., Ep., 5.19: "Nutricis meae filiam filius tuae rapuit: facinus indignum quodque nos vosque inimicasset, nisi protinus scissem te nescisse faciendum. Sed conscientiae tuae purgatione praelata petere dignaris culpae calentis impunitatem. Sub condicione concedo: si stupratorem pro domino iam patronus originali solvas inquilinatu. Mulier autem illa iam libera est; quae tum demum videbitur non ludibrio addicta sed assumpta coniugio, si reus noster, pro quo precaris, mox cliens factus e tributario plebeiam potius incipiat habere personam quam colonariam. Nam meam haec sola seu compo sitio seu satisfactio vel mediocriter contumeliam emendat; qui tuis votis atque ami citiis hoc adquiesco, si laxat libertas maritum, ne constringat poena raptorem". Es interesante que uno de los términos que Sidonio utiliza para calificar a ese colonus sea justamente el de tributarius, categoría que para Whittaker ([1987], 113) haría referencia a campesinos que habían caído en dependencia personal.

${ }^{693} \mathrm{Sid} .$, Ep., 4.9: "Interveni proxime Vectio inlustri viro et actiones eius cotidianas penitissime et veluti ex otio inspexi. Quas quoniam dignas cognitu inveni, non indignas relatu existimavi. Primore loco, quod iure ceteris laudibus anteponemus, servat inlaesam domino domus par pudicitiam; servi utiles (rustici morigeri, urbani amici) oboedientes patronoque contenti; mensa non minus pascens hospitem quam clientem; humanitas grandis grandiorque sobrietas".
} 
probablemente estuvieran cumpliendo con un ritual semejante al de la mejor documentada salutatio de tiempos tardo-republicanos y alto imperiales ${ }^{694}$.

Además de la deferencia, puede que en ocasiones, y sobre todo hacia fines del imperio, determinados vínculos entre patronos y clientes relativamente acomodados implicaran el servicio de $\operatorname{armas}^{695}$. En una carta del año 474 a su cuñado Ecdicio, Sidonio recuerda cómo tiempo atrás este había defendido Clermont-Ferrand de los enemigos, primero con una pequeña compañía propia de tan solo dieciocho hombres y luego reclutando un ejército digno de la fuerza pública ${ }^{696}$. Durante el siglo $\mathrm{V}$, el desinterés o la imposibilidad por parte del gobierno central de presentar fuerzas militares en todos los escenarios de conflicto, forzó la autodefensa de muchas regiones. Dependientes de la aristocracia patrullaban los caminos adyacentes a sus propiedades $^{697}$. Además de la Galia, se puede constatar la aparición de milicias locales en Britania desde 410 y en Nórico desde aproximadamente 460. En Hispania sabemos de reclutamientos de esclavos hechos por dos aristócratas contra el usurpador Constantino III $^{698}$. Esto no debe llevarnos a suponer que la defensa recayera principalmente en manos de los habitantes locales, caso que parece haberse dado únicamente en Britania. En el resto de las regiones occidentales quienes cumplieron ese rol fueron las tropas bárbaras federadas y los ejércitos regulares ${ }^{699}$. De todas formas, la aparición eventual de milicias locales lideradas por aristócratas dio lugar al reclutamiento tanto de campesinos dependientes y esclavos -como ocurrió en la Hispania del siglo V- como de clientes. Pero mientras que para los primeros el servicio militar era una obligación a cumplir, para los segundos representaba una prestación a intercambiar por algún beneficio.

\footnotetext{
${ }^{694}$ Saller 1982, 128-129.

${ }^{695}$ Este tipo de clientelismo parece que existió en la Galia pre-romana, como sugiere Drinkwater (1989, 189-191), pero no podemos sostener la existencia de una continuidad hasta fines de la Antigüedad.

${ }^{696}$ Sid., Ep., 3.3: "Illud in te affectum principaliter universitatis accendit, quod quos olim Latinos fieri exegeras barbaros deinceps esse vetuisti. Non enim potest umquam civicis pectoribus elabi, quem te quantumque nuper omnis aetas ordo sexus e semirutis murorum aggeribus conspicabantur. Cum interiectis aequoribus in adversum perambulatis et vix duodeviginti equitum sodalitate comitatus aliquot milia Gothorum non minus die quam campo medio, quod difficile sit posteritas creditura, transisti. [...] Taceo deinceps collegisse te privatis viribus publici exercitus speciem parvis extrinsecus maiorum opibus adiutum et infrenes hostium ante discursus castigatis cohercuisse populatibus". Según Sidonio, la última de las levas se había realizado sin la ayuda de los poderosos de la ciudad. Esto indicaría que era relativamente accesible para los sectores aristocráticos recurrir a fuerzas militares privadas, ya fuera de manera directa o mediada a través de otros actores.

${ }^{697}$ Sid., Ep., 2.9.

${ }^{698}$ Oros., Hist., 7.40.5-7.

${ }^{699}$ Wood 2000, 505-507.
} 
Llegados a este punto es oportuno hacer un balance, deteniéndonos en una cuestión que resulta de crucial importancia en cuanto a la conceptualización que estamos haciendo del patronazgo. Hemos planteado anteriormente que se puede inferir, a partir de las expresiones de Salviano, que determinados sectores campesinos un poco más acomodados lograron evadir las responsabilidades fiscales a través del establecimiento de vínculos personales con sectores más poderosos en términos que reportaban un provecho. Asimismo, hemos corroborado la existencia de formas de patronazgo "tradicional" a través del testimonio de Sidonio. Lo que nos interesa subrayar ahora es que el Estado no era un actor necesario para que se llevaran a cabo este tipo de relaciones. La huida del fisco no era el elemento que determinaba que el cliente "buscara" la protección del patrono, aunque el beneficio consistiera efectivamente en la evasión de los impuestos.

Podemos citar, finalmente, una última referencia a este tipo de clientelismo. Se trata de la ya mencionada carta en la que Sidonio solicita al obispo Censorio que auxilie a un diácono empobrecido que ha huido de las devastaciones godas. Concretamente, le pide que le condone el pago de la renta por una tierra de su diócesis en la que el diácono se ha instalado y que ha cultivado. Sidonio le garantiza a Censorio que el clérigo encomendado le estará sumamente agradecido $^{700}$. El lazo descrito beneficiaría notoriamente al cliente potencial, que se establecería sobre una parcela sin la obligación de pagar los cánones corrientes, pero probablemente también al obispo Censorio, que quizás necesitara gente leal dentro de su iglesia o simplemente consiguiera reforzar a través de este favor su relación de amistad con Sidonio. Es sugestivo, asimismo, el interés de Sidonio por el porvenir del diácono, que no parece ser otra cosa que un cliente suyo. Este tipo de vínculos sí se asemejan bastante a la definición corriente de patronazgo: son relativamente igualitarios -aunque vinculen a personas de diferentes status - y voluntarios $^{701}$. El Estado no tenía porqué condenarlos.

Anteriormente planteábamos que cierta historiografía no captó acabadamente el rol que jugó el Estado tardo-romano en la aparición de este nuevo patrocinium. Lo que deberíamos dejar en claro en primer lugar es el hecho de que la escasez de fuentes no nos permite constatar el fenómeno en todo el imperio, por más que muy a menudo así se

\footnotetext{
${ }^{700}$ Sid., Ep., 6.10. Véase supra la transcripción, n. 649.

${ }^{701}$ Voluntad que debe contextualizarse históricamente. El episodio mencionado en esta carta da cuenta de los límites de la libre elección de los individuos en el paso de la Antigüedad a la Edad Media. En este caso, las relaciones interaristocráticas -reglamentadas consuetudinariamente por medio de la amicitiadeterminaron el accionar de Sidonio, Censorio y el diácono encomendado.
} 
haga $^{702}$. Pero tampoco se puede negar su existencia fuera de las zonas documentadas ${ }^{703}$. El concepto de Wickham del patronazgo como gemelo malvado del Estado tributario puede ayudarnos a resolver este problema ${ }^{704}$. Podemos suponer que cuando el Estado presionaba mucho sobre sus contribuyentes, abonaba el terreno para la emergencia de prácticas evasivas entre las que podía aparecer el patronazgo. Pero a partir de este punto es necesario ser cautos y no solo atenernos al análisis de las regiones para las cuales contamos con información adecuada, sino también a las peculiaridades de su situación histórica concreta.

La noción de gemelo malvado tiene otras derivaciones que hay que resaltar. Muchos historiadores han asociado los patrocinios con la debilidad del estado antes que con su fortaleza. Su planteo encierra una lógica de círculo vicioso, al proponer que cuanto más se afanaba el imperio por aumentar la recaudación, más crecía la evasión fiscal, que iba cercenando regiones cada vez más amplias del dominio central. La solución de continuidad a este encadenamiento de causas y efectos no habría sido otra que la propia desaparición del Estado ${ }^{705}$. Entendemos que esta tesis debe corregirse. Siria y Egipto, son los dos distritos orientales para los cuales tenemos documentada de manera específica la evasión de impuestos, a través de Libanio y de leyes del Codex Theodosianus respectivamente ${ }^{706}$. En estas regiones, el pago del impuesto no estaba de

${ }^{702}$ E. g. Alföldy 1987, 285-290 y Jones 1964, 775-778, aunque este último diferencia una modalidad oriental de otra occidental.

${ }^{703}$ Hay datos específicos sobre Siria (Lib., Or., 47) y Egipto (C. Th., 11.24.1 y 11.24.3), además de los ya mencionados sobre la Galia. El resto de las leyes del Código Teodosiano englobadas bajo el título "De patrociniis vicorum" están dirigidas a los prefectos del pretorio de Oriente, no a Egipto en particular como afirman, por ejemplo, Garnsey y Woolf $(1989,163)$. Véase PLRE, 2, 1250-1252, sobre esta cuestión.

${ }^{704}$ Wickham 2005, 528.

705 Alföldy 1987, 285-290. Whittaker y Garnsey (1998, 310-311) son menos exagerados, pero subrayan la aparición durante el siglo $\mathrm{V}$ de terratenientes que habían dejado de ser leales a Roma, relacionando directamente este hecho a la evasión fiscal y el debilitamiento del Estado. Cabe agregar, además, que en este trabajo Garnsey adopta un punto de vista bastante diferente al sostenido junto a Woolf en 1989 con respecto al patrocinium, destacando tanto el carácter antiestatal del fenómeno como la pérdida de la propiedad por parte de los campesinos que se sometían a la protección de los terratenientes. No hay mención alguna a la anterior hipótesis de una mayor competencia entre patronos. Por último, hay que decir que Garnsey (2003) plantea la idea de que el patronazgo en la Galia tardo-romana se convirtió en una relación considerablemente más "explotativa" que antes debido a una presencia más fuerte de los terratenientes a nivel local. El autor parte allí del supuesto de que el patronazgo tradicional entre grandes propietarios absentistas y campesinos tenía un carácter laxo. Como consecuencia, permitía a estos últimos desarrollar más libremente vínculos de ayuda horizontal, pero a la vez les brindaba escasa asistencia en situaciones apremiantes, a diferencia del patronazgo tardo-romano. En nuestra opinión, la idea de que un patrono absentista no podía establecer relaciones cercanas con los campesinos desestima el rol que podían jugar los agentes que administraban las grandes propiedades en nombre de los aristócratas, los cuales podían actuar como sus mediadores (brokers). Jones $(1964,788-792)$ trata brevemente el problema de la administración de propiedades rural por parte de aristócratas absentistas.

${ }^{706}$ Véase la nota 125. 
ninguna manera amenazado por los patronos privados. Aquí cobra toda su dimensión el concepto de patronazgo como gemelo malvado, como producto derivado del cobro de impuestos: una forma de poder rural que dependía para su aparición de una estructura estatal en funcionamiento ${ }^{707}$. Por supuesto, esto no implica que el Estado tolerara estas prácticas.

El caso de la Galia tampoco se ajusta plenamente a la idea de un Estado moribundo. Los planteos de Salviano podrían inducirnos a creer esto, pero lo cierto es que constituyen la denuncia de una situación de corrupción sobre un sistema en funcionamiento, no de un colapso físcal. Recordemos además que la connivencia con el poder público fue un componente que estuvo muy presente en estas prácticas.

Ahora bien, hemos dejado en claro también que el funcionamiento del aparato tributario desde al menos los tiempos de Salviano en adelante distaba de ser óptimo en la Galia del sur y en occidente en general. Como veremos, un efecto disruptivo de la incipiente crisis eran las huidas.

Para cerrar este apartado, queremos insistir sobre una consideración en torno a este tipo de patronazgo. Según nuestra óptica, este vínculo fue desde un comienzo una relación de explotación, involucrara o no la pérdida de la propiedad. Excluimos de esta consideración, por supuesto, los casos analizados de patronazgo que colocaban en el papel de clientes a segmentos más acomodados del campesinado o incluso sectores de la baja aristocracia. Los campesinos más empobrecidos que buscaban la protección de los poderosos ya eran una clase explotada, en tanto buena parte de su cosecha se la quitaba el poder público. Como solución contra una explotación recurrían a otra, tal vez un poco más flexible o que le permitía un desahogo inicial, pero que muchas veces incluso terminaba en la pérdida de la propiedad. Ver en los patrocinios una alianza entre señores y campesinos contra el Estado -como hacen algunos autores- nos parece que sobredimensiona la posibilidad de una comunidad de intereses donde en realidad hay

\footnotetext{
${ }^{707}$ Wickham $(2005,527-535)$ propone además que cuando el sistema fiscal dejó de existir el patronazgo que se daba en su contra perdió su propósito. Esto podría conducir a una confusión entre "génesis" y "funcionamiento" de las relaciones de dominación. La crisis del aparato tributario interrumpió efectivamente una forma de construcción de relaciones de dependencia, pero esto no implicó que muchos vínculos de subordinación que tuvieron este origen continuaran existiendo, en la medida en que su dinámica discurría ahora por otros carriles. Resulta difícil pensar, por ejemplo, en campesinos obteniendo graciosamente de sus señores la supresión del pago de renta porque el impuesto cuya evasión constituyó en algún momento la causa de su caída en dependencia hubiese dejado de recaudarse. Según nuestro criterio, lo que determinó la debilidad a largo plazo de las aristocracias frente al campesinado fue la crisis general del orden político que sustentaba su dominio social.
} 
clases en conflicto $^{708}$. Tampoco deberíamos analizar la protección como si se tratara de una elección libre por parte del campesino ${ }^{709}$. Más bien habría que sospechar lo contrario, habida cuenta del celo que en general muestra esta clase por la naturaleza recíproca de sus relaciones horizontales y verticales ${ }^{710}$. Salviano es categórico al plantear que los campesinos no tenían otra opción que ponerse bajo protección de los poderosos. La exageración de su tono no desvirtúa la crudeza de la realidad.

\section{LAS BAGAUDAS}

Si bien los historiadores modernos han exagerado en ocasiones la importancia de las bagaudas en el derrotero histórico del imperio romano, el fenómeno reviste una relevancia incontestable para el problema abordado en esta tesis ${ }^{711}$. Lo primero que es preciso señalar al comenzar su tratamiento es que la documentación para determinar siquiera sus atributos fácticos básicos es muy parca. Las bagaudas aparecieron en la Galia en el siglo III y en el V. En 285, poco después de que Diocleciano obtuviera la púrpura, estalló la primera de las revueltas. Las invasiones bárbaras y las luchas dinásticas habían afectado particularmente a la región, minando allí la autoridad imperial. Las informaciones que manejaba el Estado indicaban que se trataba de un ejército de campesinos y bandoleros que habían saqueado los campos y atacado las ciudades. Una vez en el trono, Diocleciano tomó cartas en el asunto, enviando a Maximiano y logrando una rápida pacificación ${ }^{712}$.

Más de un siglo después, vuelven a aparecer menciones a "bagaudas". En 409 se produjo un levantamiento en el Tractus Armoricanus que no fue aplastado hasta $417^{713}$. Esta sublevación tuvo lugar tras los ataques sajones a Britania, Belgica II y el Tractus Armoricanus mismo. En este último lugar, Tibatón lidera otra revuelta en 435-437, en momentos en que Roma luchaba contra los visigodos en el sur y con los burgundios en

\footnotetext{
${ }^{708}$ Van Dam 1985, 25-56; Alföldy 1987, 246-290.

${ }^{709}$ Como se desprende de Wickham 1989.

710 Scott 1985, 43-49.

711 Sobre la etimología del término "bacauda" véase Sánchez León 1996b, 31-34. Por "bagauda" entendemos aquí tanto el fenómeno en sí como a sus integrantes (los "bagaudas").

712 Thompson [1952], 334-335 y 340-341. Las fuentes sobre las bagaudas están recopiladas en Sánchez León 1996a.

${ }^{713}$ Zos., 6.5.3.
} 
Bélgica $^{714}$. En 442, una vez reanudada la paz con los visigodos, Aecio estableció en suelo galo a los alanos de Goar, muy probablemente con el objetivo de controlar las bagaudas $^{715}$. En 446 Tours se defendió de los armoricanos ${ }^{716}$. Finalmente, los alanos derrotaron en 448 a los bagaudas y su líder, el médico Eudoxio, huyó con los hunos ${ }^{717}$. Por otra parte, también estallaron revueltas en los Alpes a comienzos de siglo. La primera noticia que se tiene de ellas data de 407/408, cuando el general Saro, perseguido por los generales del usurpador Constantino III, debió tributar a los bagaudas a cambio del libre paso hacia Italia $^{718}$. Es probable que Constantino haya reprimido esta revuelta en 410 , camino hacia Italia, aunque también cabe la posibilidad de que sobreviviera hasta $417^{719}$. En tiempos de Salviano todavía había bacaudae en actividad $^{720}$. Finalmente, debe mencionarse que también se produjeron revueltas en Hispania, en la zona de Tarraconense ${ }^{721}$.

A la hora de comprender estos procesos, debe señalarse en primer término que no parece existir ningún continuum entre las bagaudas del siglo III y las del siglo V. Según John Drinkwater, el término "bacauda" sufrió durante esta última centuria un cambio semántico para pasar a utilizarse peyorativamente como sinónimo de bandido $^{722}$. En tal sentido, las fuentes presentarían fenómenos distintos bajo una misma etiqueta. Los análisis modernos del problema han derivado en tres líneas argumentativas principales $^{723}$. La primera de ellas es la de los historiadores que las entienden como revueltas campesinas. Para Edward A. Thompson, esto habría derivado en la instauración en Armórica de una sociedad sin terratenientes, con un aparato estatal rudimentario y con una justicia más equitativa. Aquí es fuerte su fundamentación en el Querolus, una comedia de inicios del siglo V en la que de un modo algo críptico se haría referencia a que al norte del río Loira imperaría un ius gentium y los campesinos

\footnotetext{
${ }^{714}$ Chron. Gall. a. CCCCLII, 117 (año 435) y 119 (año 437); Const., V. Germ., 28 y 40.

${ }^{715}$ Chron. Gall. a. CCCCLII, 127 (año 442); Bachrach 1973, 63.

${ }^{716}$ Sid., Carm., 5.210-211.

${ }^{717}$ Chron. Gall. a. CCCCLII, 133 (año 448).

${ }^{718}$ Zos., 6.2.5. Sulpicio Severo indica que había bandidos (latrones) en los Alpes en V. Mart., 5, pero la referencia no puede tomarse como testimonio claro de las bagaudas como pretende Thompson ([1952], 341, n. 24).

719 Sánchez León 1996b, 17-18.

${ }^{720}$ El sacerdote se refiere a los bagaudas sin hacer mención del lugar en el que se encontraban, pero probablemente estuviese pensando en la Galia (De gub. Dei, 5.6.22 y 24-26).

${ }^{721}$ Hyd., Chron., 125 (año 441), 128 (año 443), 141 (año 449) y 158 (año 454).

722 Drinkwater 1992, 208.

${ }^{723}$ Véase Sánchez León 1996 b, 155-168 para referencias a trabajos del siglo XVI en adelante.
} 
tendrían allí el poder de decisión ${ }^{724}$. Sin embargo, no hay en dicha obra mención concreta a las bagaudas y el testimonio ha sido descartado por otros autores ${ }^{725}$. Tanto las bagaudas como los bárbaros habrían sido para Thompson válvulas de escape para un campesinado extremadamente oprimido ${ }^{726}$. En este punto, la interpretación retomaba casi al pie de la letra lo sostenido por Salviano en su De gubernatione dei respecto a que aquellos que perseguidos por los recaudadores fiscales no se ponían bajo protección de potentes, sino que huían con los bárbaros o las bagaudas ${ }^{727}$.

Van Dam esbozó otra interpretación a mediados de la década de 1980. En su opinión, las bagaudas estuvieron encabezadas por personajes con fuerte poder local. En este sentido, se habrían constituido como una garantía de asistencia y seguridad para el campesinado y no como unas formas comunitarias más o menos igualitarias fundadas en las márgenes de la civilización romana. Se encuadrarían, según este autor, en una tradición local muy asentada de relaciones de patronazgo, la cual tendía a hacerse más fuerte cada vez que la presencia imperial en estas tierras se debilitaba o desaparecía ${ }^{728}$.

Finalmente está la interpretación ofrecida por Drinkwater. La novedad del análisis de este autor reside en su caracterización de los actores involucrados. Apoyándose principalmente en la última cita de Salviano, sostiene la hipótesis de que las bagaudas habrían estado integradas por individuos de buena cuna y educación, miembros de una clase curial en aprietos por sus responsabilidades fiscales y víctima de las actividades de expropiación -latrocinium - de los más ricos. No habrían estado, entonces, encabezadas por coloni, atados psicológica y económicamente a las tierras

\footnotetext{
${ }^{724}$ Quer., 2.30:

LAR. Ha, ha, he, latrocinum non potentiam requiris. Hoc modo nescio edepol quemadmodum praestari hoc possit tibi. Tamen inueni: habes quod exoptas. Vade, ad Ligerem uiuito. QVER. Quid tum?

LAR. Illic iure gentium uiuunt homines; ibi nullum est praestigium, ibi sententiae capitales de robore proferuntur et scribuntur in ossibus; illic etiam rustici perorant et priuati iudicant; ibi totum licet. Si diues fueris, patus appellaberis: sic nostra loquitur Graecia. O silvae, o solitudines, quis uos dixit liberas? Multo maiora sunt quae tacemus. Tamen interea hoc sufficit.

${ }^{725}$ Golvers (1984) plantea que el pasaje del Querolus podría ser una referencia despectiva a la vida en el monasterio de Manmourtier. Drinkwater $(1992,210)$ avala esta lectura.

${ }^{726}$ Thompson [1952].

${ }^{727}$ Salv., De gub. Dei, 5.5.21-22: “Inter haec vastantur pauperes, viduae gemunt, orfani proculcantur, in tantum ut multi eorum, et non obscuris natalibus editi et liberaliter instituti, ad hostes fugiant, ne persecutionis publicae adflictione moriantur, quaerentes scilicet apud barbaros Romanam humanitatem, quia apud Romanos barbaram inhumanitatem ferre non possunt. Et quamvis ab his, ad quos confugiunt, discrepent ritu, discrepent lingua, ipso etiam, ut ita dicam, corporum atque induviarum barbaricarum foetore dissentiant, malunt tamen in barbaris pati cultum dissimilem quam in Romanis iniustitiam saevientem. Itaque passim vel ad Gothos vel ad Bacaudas vel ad alios ubique dominantes barbaros migrant, et commigrasse non paenitet; malunt enim sub specie captivitatis vivere liberi quam sub specie libertatis esse captivi". Véase también De gub. Dei, 5.5.24-26.

${ }^{728}$ Van Dam 1985, 25-55.
} 
que trabajaban, ni por los grandes terratenientes, sino por la baja aristocracia. Para Drinkwater, las bagaudas del siglo $\mathrm{V}$ pudieron haber adoptado, grosso modo, tres formas distintivas:

1) Las aristocracias venidas a menos habrían migrado desde sus tierras en el sur de la Galia hacia las tierras desiertas y abandonadas por la administración central con sus dependientes y con campesinos libres, ofreciendo a su vez liderazgo a las poblaciones rurales indígenas.

2) Los migrantes, con o sin sus dependientes, se habrían trasladado a zonas abandonadas por la administración romana, pero se sometieron a la autoridad de los grandes aristócratas allí establecidos y que no se habían trasladado al sur como otros pares suyos. Esta interpretación se asemeja a la de Van Dam.

3) Los refugiados habrían migrado a un área que, aunque nominalmente romana, parecía un Estado bárbaro a los ojos de aquellos que se habrían quedado en el sur. Allí -quizás pudiera ser el caso de las bagaudas de Armórica- aquellos se habrían resistido a cualquier tipo de control por parte de la administración central, estableciendo un orden social más equitativo, en el sentido de impedir la conformación de una aristocracia poderosa. Este modelo se acerca a las ideas de Thompson $^{729}$.

Al parecer estamos en presencia de un problema complejo y plural, mal documentado, de procesos diversos unidos solo por el descrédito de una etiqueta peyorativa. De cualquier forma, en la medida en que su epicentro parece haber tenido lugar en el norte de la Galia, no incumbe a este trabajo indagar en profundidad en él. Interesa rescatar, en cambio, el hecho de que al parecer grupos de campesinos e incluso miembros de la baja aristocracia, acosados por los impuestos, migraron a regiones en las que existían movimientos catalogados como bagaudas. La referencia de Salviano es escueta y no permite cuantificar el fenómeno.

${ }^{729}$ Drinkwater 1992. 
6

\section{ARISTÓCRATAS Y CAMPESINOS (II):}

c. $480-$-c. 550

\section{EL CONFLICTO DE CLASES}

Hemos planteado en el capítulo anterior que el problema de si las sociedades precapitalistas eran sociedades de clase o de status podría ser saldada a partir del concepto de "clase estamental" propuesto por Kuchenbuch y Michael. Sin embargo, resulta provechoso retomar ahora la noción de "lucha de clases" de G. E. M. de Ste. Croix:

Utilizo el término lucha de clases para la relación fundamental existente entre las clases (y sus respectivos componentes individualmente considerados), que implica fundamentalmente explotación o resistencia a ella. No supone necesariamente una acción colectiva por parte de una clase como tal, y puede incluir o no una actividad en el plano político, si bien dicha actividad política resulta cada vez más probable a medida que se agudiza la tensión de lucha de clases. Se supone asimismo que una clase que explote a otras empleará formas de dominación política y opresión contra ellas siempre que pueda: la democracia mitigará semejante proceso $^{730}$.

$[\ldots]$

\footnotetext{
${ }^{730}$ de Ste. Croix 1988, 61.
} 
La verdadera existencia de las clases, en el sentido en que he definido el término (siguiendo, en mi opinión, a Marx), supone inevitablemente tensión y conflicto de clases $^{731}$.

Pero si bien el conflicto es inherente a las sociedades de clases, desde mediados del siglo $\mathrm{V}$ se abre un periodo de agudización en el que las distintas formas de resistencia a la explotación comienzan a resquebrajar el orden social existente. La caída del Estado romano acelera esta dinámica.

\section{Fugitivos}

El destino de los campesinos que huían de los impuestos no era siempre el brazo protector de un poderoso local. Salviano menciona cómo los pobres, las viudas, los huérfanos e incluso personajes de posición relativamente acomodada se fugaban hacia los bárbaros frente a las persecuciones del poder público ${ }^{732}$. Se sabe a partir de otros testimonios que a comienzos del siglo $\mathrm{V}$ personas pertenecientes a sectores marginales se unieron a las tropas invasoras con el objetivo de encontrar alivio sirviendo como solados $^{733}$. Hemos hecho referencia al caso de los habitantes de Hispania que según Orosio huyeron hacia los bárbaros. Pero Salviano parece estar refiriéndose a un fenómeno distinto, pues los fugitivos de quienes habla no tenían como destino ejércitos en movimiento o acantonados circunstancialmente sino territorios controlados por el enemigo, en los cuales probablemente pudieran asentarse en términos más convenientes. De ahí que el otro derrotero mencionado para estos mismos migrantes, en términos análogos al anterior, fueran las bagaudas ${ }^{734}$. Las leyes también dan cuenta de este

\footnotetext{
731 de Ste. Croix 1988, 67.

${ }^{732}$ Salv., De gub. Dei, 5.5.21 (véase la transcripción en el capítulo anterior, n. 727). Queda claro que Salviano está pensando principalmente en las clases inferiores -en particular en el campesinado. Esto queda patente cuando afírma que la opresión pública la sufrían "omnibus ferme humilioribus" (5.7.27: "Ita ergo et cum omnibus ferme humilioribus agitur: una enim re ad duas diversissimas coartantur. Vis summa exigit, ut adspirare in libertatem velint, sed eadem vis posse non sinit, quae velle compellit").

${ }^{733}$ Liebeschuetz 1990, 17. Este fenómeno no fue exclusivo de occidente. A fines del siglo IV, Tribigildo saqueó el interior de Asia menor al mando de frigios, pero en el camino se le unieron esclavos y desarraigados (Zos., 5.13).

${ }^{734}$ Salv., De gub. Dei, 5.5.22 y 5.5.24-26. Otros fugitivos convergían en estas corrientes empujados por causas puntuales. Tenemos por ejemplo información del año 400 acerca de desertores en la región de la prefectura de las Galias, en una ley que preveía castigos para los soldados que, encargados de volver a reclutarlos, incurrieran en abusos contra los campesinos (C. Th., 7.18.10: "Si qui desertores oberrare in provinciis fuerint comprehensi, eos et comprehendi protinus volumus et ad iudicem deduci, ut auditi, cum de crimine desertionis suae confessi fuerint, carceris custodiae deputentur: de quorum nominibus ad
} 
fenómeno. En 458, a través de una disposición de Mayoriano emitida a todos los gobernadores provinciales de occidente se admitía la escasez de defensores en las ciudades pequeñas por causa de las huidas. A su vez, la misma ley, que instaba a dichas jurisdicciones a no dejar vacante el cargo mencionado para que los poderosos no pudieran actuar impunemente sobre los débiles, ponía de manifiesto que los desprotegidos de la ciudad buscaban amparo de los abusos de los funcionarios del físco en el área rural ${ }^{735}$.

Por otro lado, existen noticias sobre coloni y servi fugitivi. La citada carta de Sidonio Apolinar en la que solicitaba a su amigo cambiar el status del colonus que había establecido una relación de concubinato con su esclava testimonia una huida que resultó en un regreso para mejorar la posición. Los fugitivos podían establecer así relaciones más convenientes con la aristocracia en un contexto que, como veremos, era de escasez de brazos. Por supuesto, esto era objeto de condena legal. Valentiniano III emitió una serie de disposiciones concernientes a coloni vagi y advenii en 451, tendientes a fijarlos a la tierra. Importa menos el detalle de lo que se disponía en la ley que lo que revela: la presencia corriente de coloni originarii que habían abandonado la tierra en la que estaban adscriptos y que cambiaban repetidamente de residencia, por un lado, y de inmigrantes pobres que trabajaban temporalmente al servicio de terceros en la ciudad o

tuam sublimitatem subditis confessionibus referatur, ut instructi magistri militum, quid de his fieri oporteat, pro sui auctoritate constituant. Sin vero inventi resistendum atque armis obtinendum putaverint, tamquam rebelles in ipsis temeritatis suae conatibus opprimantur").

${ }^{735}$ Nov, Mai., 3.1 (año 458, emitida a todos los gobernadores provinciales): "De civitatum per omnes provincias positarum raritate cogitantes, quibus, fugientibus incolis, defensorum auxilio destitutis, qui unumquemque civium ab improbitatibus insolentum antiquae ordinationis studio vindicare consueverant, sollicitudo nostris ordinationibus summovenda possidendi, priscae consuetudinis morem revocandum esse censuimus, ut probis moribus, honestate, providentia viri iudico universitatis electi, auctoritatem tuendae in civitatibus suis plebis accipiant, et quaecunque utilitatem publicam respiciunt, concessae per leges privilegio dignitatis vel exsequendi vel insinuandi auribus mansuetudinis nostrae habeant potestatem. Hoc enim modo fieri potest, ut, repressis per eos insolentiae vitiis quoque, qui accidentia in provinciarum nostrarum parte tractatum intenti curis maioribus ignoramu, eorum ad emendandum suggestionibus instruamur, et ii, qui per iniuriam compulsorum rurales habitationes et solitudines expetunt, sub defensorum tuitione degentes publicis se urbium conspectibus, repetiti domicilii habitatione, restituant. Quapropter praeceptionis nostrae tenore comperto, universarum civitatum, quae sunt, inhabitantium frequentia celebres, in tuae potestatis arbitrio constitutae, municipes, honoratos plebemque commoneat, ut adhibito tractatu atque consilio sibi eligant defensoremm factumque dematuren, ut sub hac solennitate Desideria urbium singularum ad nostram mansuetudinem dirigan (quia ipsos provinciales propter expensas vel itineris laborem ad comitatum venire non patimur), ut compertis eorum moribus arque personis, quos praeter ambitum dignos tali ministerio et honore iudicemus, idóneos defensores confirmatio constituat". 
en el campo pero que tenían tendencia a retomar el desplazamiento ${ }^{736}$. Finalmente, Salviano menciona la fuga de esclavos como una realidad cotidiana ${ }^{737}$.

La huida expresaba una rebeldía facilitada por una dificultad creciente para sostener los vínculos de dependencia. Tras la caída de Roma, a los Estados sucesores se les hizo cada vez más cuesta arriba preservar el orden establecido. Las dificultades de las autoridades públicas burgundias para mantener el aparato represivo se evidencian en algunas normas concernientes a los condes, como la que los exhortaba a que "si podían" hallaran a los ladrones de caballos y de casas que delinquían públicamente con total impunidad $^{738}$ o la que les recordaba que debían castigar a los culpables de actos criminales ateniéndose a las leyes ${ }^{739}$. También es sintomática la norma establecida en respuesta a quejas presentadas por los condes, que sancionaba a quienes golpearan a los dependientes públicos encargados de ejecutar sentencias y cobrar multas ${ }^{740}$.

El mismo juicio sobre la ausencia de orden social aparece en varias epístolas de Sidonio, como hemos visto anteriormente ${ }^{741}$. En el capítulo 3 analizamos el proceso de debilitamiento de los poderes públicos entre los siglos V y VI y aludimos a la cuestión de los fugitivi en ese contexto. Las huidas no se producían meramente porque los campesinos (esclavos, coloni o libres) se encontraban sometidos a una explotación que

\footnotetext{
${ }^{736}$ Nov. Val., 31.1.1-7.

${ }^{737}$ Salv., De gub. Dei, 4.3.15: "Quod autem de furtis servorum dicimus, hoc etiam de fuga: immo hoc rectius de fuga, quia ad fugam servos non miseriae tantum, sed etiam supplicia compellunt".

${ }^{738}$ Const. Ext., 19.1: "Multorum relatione cognovimus, caballorum fures et effractores domuum tantum se ad hanc insaniam prorupisse, ut non occulte, verum etiam publice crimina et omnia mala committant. Ideoque praeceptionem ad vos dedimus, ut, si quos caballorum fures aut effractores domuum, criminosos quam suspectos, invenire potueritis, statim capere et ad vos adducere non morentur: futurum ut is, qui capitur et ante vos adductus fuerit, si se innocentem potuerit adprobare, cum omnibus rebus suis liber abscedat neque calumniam pro eo, quod ligatus aut captus est, movere praesumat".

739 Const. Ext., 21.11: "Illut specialiter praecipientes, ut omnes comites, tam Burgundionum quam Romanorum, in omnibus iudiciis iustitiam teneant: in his, qui violentiam fortasse, superventum vel quodlibet crimen admiserint, ita fortiter distringant et vindicent, ut nullus hoc intra regionem nostram praesumat admittere. Omnes omnino causas ex legibus iudicentur, ut iustitiae ordine teneatur, sicut lex parentum nostrorum continet. Nam sic fieri manifeste cognovimus: de diversis sceleribus conpositiones inter paren tes vestros facitis, et causae legibus non iudicantur; ita popul[us vitiatur], ut similia praesumant admittere. Si quis conpositionis ita facere praesumpserit, ut ex lege expresse iudicare distulerit, multam se noverit inlaturum". La disposición se asemeja a Lib. Const., 79.4: "Quapropter omnes comites, quotiens de praefatis causis contentio fuerit generata, secundum ordinem legis istius iudicare curabunt".

${ }^{740}$ Lib. Const., 76.1: “Comitum nostrorum querela processit, quod aliqui in populo nostro eiusmodi praesumptionibus abutantur, ut pueros nostros, qui iudicia exsequuntur, quibusque multam iubemus exigere, et caede conlidant et sublata iussu comitum pignera non dubitent violenter auferre. Qua de re praesenti lege decernimus: ut quicumque post haec pueros nostros ceciderit et insolenter abstulerit, quod ex ordinatione iudicis docebitur fuisse prae sumptum, tripla satisfactione teneatur obnoxius, hoc est: ut per singulos ictus, pro quibus singuli solidi ab his inferuntur, ternos solidos is, qui percusserit, cogatur exsolvere".

${ }^{741}$ Véase el capítulo 2.
} 
podía tornarse insoportable, sino porque comenzaban a generarse condiciones objetivas para su consecución: concretamente, espacios de recepción para quienes se fugaban. Aunque en un contexto socioeconómico distinto, esto se constata en las colonias americanas, en Brasil por ejemplo ${ }^{742}$. Con el debilitamiento del sistema producto de la crisis del Estado antiguo, los fugitivos dejaron de convertirse en marginales para pasar a engrosar núcleos de campesinos independientes frente a los cuales la aristocracia no podía establecer relaciones de dominación estables. Lamentablemente, la información textual para demostrar esta hipótesis es escasísima. Un canon eclesiástico determinaba la excomunión para aquellos que tomasen como cautivos "almas que vivían tranquilas desde hacía mucho tiempo". Esto podría estar refiriéndose a antiguos fugitivos que habían logrado instalarse como libres de facto $^{743}$. En el concilio de Agde de 506 se autorizó a los obispos a vender los siervos de la iglesia que hubieren sido recuperados tras haberse escapado, pero que aún así no pudieren ser retenidos ${ }^{744}$. Sabemos que en otras regiones se incrementaron durante los siglos VI y VII las comunidades campesinas libres, nutridas muchas veces por servi fugados ${ }^{745}$. Este fenómeno puede además vincularse a las transformaciones que durante el periodo se operaron en los patrones de asentamiento, visibles, como veremos en el próximo apartado, en el registro arqueológico.

Una consecuencia directa de la dinámica bélica descrita en el capítulo 3 fue la captura de prisioneros para ser vendidos o explotados como esclavos. A modo de ejemplo para la región y el periodo que nos incumben podemos mencionar los numerosos burgundios y francos que tras ser capturados durante la reconquista ostrogoda de Provenza fueron alojados en basílicas y otros edificios públicos a la espera de un rescate o de su venta ${ }^{746}$. Años antes, Sidonio daba cuenta del funcionamiento de

\footnotetext{
${ }^{742}$ Flory 1979.

${ }^{743}$ Conc. Lyon (567-570), c. 3: “Et quia peccatis facientibus multi in perniciem animae suae ita conati sunt aut conantur assurgere, ut animas longa temporis quiete sine ulla status sui competitione viventes nunc improba proditione atque traditione aut capitavaverint aut captivare conentur, si iuxta praceptum domini regi emendare distulerint, quosqque hos, quos abduxerunt, in loco, in quo longum tempus quiete vixerunt, restaurare debeant, ecclesiae communion priventur". La disposición es aún más interesante por el hecho de ser una reinstauración de Vetus Gallica, 50, 3, hecho que evidenciaría que el fenómeno se repetía.

${ }^{744}$ Conc. Agde (506), c. 46: "Fugitivos domos suas aut familias deserentes, qui, etiamsi revocati fuerint, teneri non possunt, simili ratione ab episcopis, si voluerint aut si ita illi meruerint, distrahantur".

${ }^{745}$ Astarita 2007, 258-259.

${ }^{746}$ V. Caes., 1.32 ("Fugatis denique obsidionibus et Arelato Gothis cum captivorum inmensitate reversis, replentur baselicae sacrae, repletur etiam domus ecclesiae constipatione infidelium, eisque in grandi penuria alimenta pariter et vestitum homo Dei in pertitur affatim, donec singulos redemptionis munere liberaret") y 1.38 ("Interea omnes cautivos deultra Druentiam maximeque Arausici oppidi, qui ex toto
} 
redes de bandidos dedicadas al menos en parte al rapto de mujeres libres que luego eran vendidas. Su reflexión sobre la cuestión evidenciaba palmariamente el contexto social: si no se hace justicia, se demostrará que "en regiones y tiempos como los nuestros" no hay mejor situación al final de una disputa que al inicio ${ }^{747}$. Para un espectro espaciotemporal más amplio contamos con las abundantes referencias de los Decem libri historiarum y otras obras de Gregorio de Tours ${ }^{748}$. Pierre Bonnassie vio correctamente en este fenómeno el medio principal de aprovisionamiento de mano de obra dependiente en Europa entre los siglos VI y VIII, pero desatendió las consecuencias que estas prácticas tuvieron en la estabilidad de las relaciones de explotación ${ }^{749}$. Se adquirían

fuerat captivitati contraditus, cuius etiam partem Arelate liberaverat redimendo, mox inventos in Italia redemit, ut potuit. Et ut eis libertas plenior redderetur, imposuit cum sumptu iumentis et plaustris in via suorumque solatio et ordinatione fecit ad propria revocare"); Klingshirn 1985, 189-192.

${ }^{747} \mathrm{Sid}$., Ep., 6.4 (año 472): "Praepter officium, quod incomparabiliter eminenti apostolatui tuo sine fine debetur, etsi absque intermissione solvatur, commendo supplicum baiulorum pro nova necessitudine vetustam necessitatem, qui in Arvernam regionem longum iter, his quippe temporibus, emensi casso labore venerunt. Namque unam feminam de affectibus suis, quam forte Vargorum (hoc enim nomine indigenas latrunculos nuncupant) superventus abstraxerat, isto deductam ante aliquot annos isticque distractam cum non falso indicio comperissent, certis quidem signis sed non recentibus inquisivere vestigiis. atque obiter haec eadem laboriosa, priusquam hi adessent, in negotiatoris nostri domo dominioque palam sane venumdata defungitur, quodam Prudente ( hoc viro nomen), quem nunc Tricassibus degere fama divulgat, ignotorum nobis hominum collaudante contractum; cuius subscriptio intra formulam nundinarum tamquam idonei adstipulatoris ostenditur. Auctoritas personae, opportunitas praesentiae tuae inter coram positos facile valebit, si dignabitur, seriem totius indagare violentiae, quae, quod gravius est, eo facinoris accessit, quantum portitorum datur nosse memoratu, ut etiam in illo latrocinio quendam de numero viantum constet extinctum. Sed quia iudicii vestri medicinam expetunt civilitatemque, qui negotium criminale parturiunt, vestrarum, si bene metior, partium pariter et morum est, aliqua indemni compositione istorum dolori, illorum periculo subvenire et quodam salubris sententiae temperamento hanc partem minus afflictam, illam minus ream et utramque plus facere securam; ne iurgii status, ut sese fert temporis locique civilitas, talem descendat ad terminum, quale coepit habere principium. Memor nostri esse dignare, domine papa".

${ }^{748}$ En ocasiones se tomaba prisioneros con el objetivo de ser negociados por un rescate. Gregorio de Tours se refiere tanto a la captura (Hist., 3.6, 3.13, 3.34, 4.23, 4.29, 4.42, 5.29, 6.8.12, 8.30, 8.35, 9.7, 9.18 y 10.3), como a su rescate o liberación graciosa (Hist., 6.8, 6.23, 6.31, 7.1, 8.33, 10.6 y 10.11). Esto no excluye que en el trascurso de su cautiverio pudieran ser explotados como esclavos, como se desprende del caso ya mencionado que nos ha transmitido Enodio de Pavía o de la esclavización de un grupo de senadores relatada en Greg. Tur., Hist., 3.15. También menciona esclavos (no prisioneros) capturados en conflictos bélicos o razzias (Greg. Tur., Hist., 3.11, 3.13, 4.42, 4.49, 5.31, 9.7 y 9.24). Véase asimismo el caso de libertos de la Iglesia que estaban siendo arbitrariamente reducidos a la esclavitud tratado en Conc. Orléans (549), c. 7 ("Et quia plurimorum suggestione conperimus eos qui in ecclesiis iuxta patrioticam consuetudinem a servitio fuerint absoluti, pro libito quorumcumque iterum ad servitium revocari, impium ese tractavimus, ut, quod in ecclesia Dei consideratione a vinculo servitutis absolitur, irritum habeatur, adeo pietatis causa communi consilio placuit observandum, ut, quacumque mancipia ab ingenuis dominis servitute laxantur, in ea libertate maneant, quam tunc a dominis perceperunt. Huiusmodi quoque libertas si a quocumque pulsata fuerit, cum iustitia ab ecclesiis defendatur, praeter eas culpas, pro quibus leges conlatas servis revocari iusserunt libertates").

${ }^{749}$ Bonnassie 1991, 47-48. 
tantos esclavos como se perdían a manos de los ejércitos y las bandas armadas, de modo que la situación era la de un constante flujo y reflujo entre unas y otras regiones ${ }^{750}$.

Por otro lado, la existencia de entidades políticas en constante conflicto dificultaba la persecución de esclavos que huían de unas a otras ${ }^{751}$. Sidonio se refiere a servi que huían hacia territorio bretón ${ }^{752}$. Como hemos visto en el capítulo 3 , numerosas leyes burgundias concernientes a fugitivi dan cuenta de la extensión del fenómeno en el centro-sudeste de la Galia entre fines del siglo V y comienzos del VI. Las huidas de esclavos del reino burgundio que tenían como destino los territorios alamán y franco debieron de ser lo suficientemente frecuentes como para que se estableciesen dos disposiciones específicas con respecto a quienes volvían a adquirir estos esclavos, instalándolos nuevamente en el reino ${ }^{753}$. El fenómeno no era en modo alguno privativo de este Estado, pues una disposición contenida en las Constitutiones Extravagantes establecía que si un esclavo que había sido vendido fuera del país volvía a su lugar de origen debía gozar del status de libre ${ }^{754}$. Suspicazmente, la ley se desentendía del estatuto legal del inmigrante, lo que conduce a pensar que se trataba de personas que aún eran servi. La disposición invita a pensar, además, que el Estado no tenía un interés particular por el mantenimiento de la esclavitud como institución, más allá de la protección de los derechos de propiedad de sus súbditos. De haberlo tenido, quizás las normas concernientes a la persecución de fugitivi habrían tenido una mayor presencia en las compilaciones legales. No lo sabremos nunca, pero en cualquier caso, ese desinterés relativo otorga mayor fuerza probatoria a las leyes en cuestión con respecto al problema estudiado. Finalmente, a menudo los pactos que regulaban los límites entre Estados estipulaban el intercambio de fugitivos ${ }^{755}$.

Otras referencias confirman que la fuga de esclavos era un fenómeno extendido a toda la Galia ${ }^{756}$.

\footnotetext{
${ }^{750}$ Como sostiene Bonnassie (1991, 49-51) los esclavos de los siglos V-VIII provenían en su mayoría del interior de las propias sociedades, no del exterior.

${ }^{751}$ Greg. Tur., Hist., 3.15, 5.48-49 y 6.31 .

${ }^{752}$ Sid., Ep., 3.9: "Gerulus epistularum humilis obscurus despicabilisque etiam usque ad damnum inno centis ignaviae mancipia sua Britannis clam sollicitantibus abducta deplorat".

${ }^{753}$ Lib. Const., 56.1 y Const. Ext., 21.9 (véase la transcripción de estas leyes en el capítulo 3, notas 381 y 387 respectivamente).

${ }_{755}^{754}$ Const. Ext., 21.3 (véase la transcripción en el capítulo 3, n. 387).

${ }^{755}$ Smith 2005, 158 .

${ }^{756}$ Sid., Ep., 5.19; Greg. Tur., Hist., 5.3, 5.48, 6.31, 7.46, 8.21, 9.6, 9.38, 10.2 y 10.15; Greg. Tur., Glor. Conf., 66 y 67 (y quizás 92 y 93); Greg. Tur., V. Pat., 16.3 y 19.1; Conc. Orléans (511), c. 3; Conc. Épaône (517), c. 39 y Conc. de Orléans (541) cc. 24 y 30.
} 
La rebeldía de los explotados se expresaba también mediante el uso de la violencia. Sidonio menciona en una de sus cartas el asesinato de un aristócrata a manos de sus propios esclavos. El hecho de que finalmente hubiera sido posible castigar a los responsables podría ser esgrimido contra lo que venimos planteando. Pero Sidonio no se engaña: pese a que se ha ajusticiado a los criminales, la historia lo ha llenado de horror y no puede sino pensar en ella ${ }^{757}$. El tono parece esconder un miedo real ante un peligro latente y no una mera exageración retórica. Una disposición burgundia establecía que sin importar cuán a menudo un mismo esclavo fuese acusado de un delito, debía observarse la práctica de llevarlo ante el juez y proceder a la investigación del hecho ${ }^{758}$. Sucesos similares son narrados por Gregorio de Tours en sus Decem libri Historiarum $^{759}$. Recuérdese en este sentido lo antedicho en torno a la extensión del delito menor en la sociedad temprano medieval.

Esta es la diferencia más importante entre las fugas producidas entre c. 275-c. 425 y las del periodo que estamos estudiando. En su análisis de las huidas de esclavos en la época tardo-romana, Kyle Harper ha planteado que pese a que el fenómeno estuvo claramente presente, los amos tenían a su disposición medios públicos y privados para prevenir y recuperar a sus dependientes. Hay evidencias de redes privadas para detectar y apresar fugitivos. En cuanto al Estado, prestaba su ayuda de varias formas, según este autor: 1) obligaba a los vendedores a reportar huidas anteriores; 2) castigaban mediante leyes a los fugados; 3) prestaba ayuda material para su detección y recuperación y 4) castigaba a quienes les prestaran auxilio ${ }^{760}$. Para Harper, los fugados del periodo tardoromano debieron de haber tenido pocas chances de éxito, pero en el transcurso del siglo $\mathrm{V}$ esta fue una posibilidad cada vez más concreta para los dependientes romanos. Esto era percibido por los contemporáneos: Sidonio vincula en una de sus cartas la presencia de fugitivos de las haciendas con la ausencia de un poder público determinado a

\footnotetext{
757 Sid., Ep., 8.11 (año 480): “namque confuso pectori maeror, et quidem iure, plurimus erat, cum paginis ista committerem sola. Neque enim satis mihi aliud hoc tempore manu sermone consilio scribere loqui volvere libet".

${ }^{758}$ Lib. Const., 77.1: “Quotiens servus, vocatus in crimine, necesse est, ut iudici sub inscriptione tradatur, haec habendae discussionis forma servabitur: ut servi domino tantum pretium numeretur; et si servus obiectum sibi crimen sub tormentis fuerit confessus, solidi, qui inlati fuerant, accusantis partibus reformentur, servus morte debita condemnetur. Quo facto, criminosi servi dominus eum, qui rem perdiderit, simpla solutione legibus reddat indemnem".

${ }^{759}$ Greg. Tur., Hist., 7.46-47, 10.2, 10.18 y 10.25.

${ }^{760}$ Harper 2011, 257-260.
} 
impedirlo $^{761}$. Por supuesto que los Estados post-romanos continuaron condenando la fuga de esclavos; la diferencia está en su capacidad para hacer efectivo el castigo de los culpables. Entre las leyes de castigo a los fugitivi del siglo IV había una que se encargaba especialmente de quienes migraban a territorio bárbaro, lo que pone en evidencia que la presencia cercana de otro Estado u entidad política podía favorecer el éxito de la empresa ${ }^{762}$. Podemos trazar nuevamente una analogía con el Nuevo Mundo: los esclavos del sur de los Estados Unidos intentaban fugarse a los Estados del norte del país o a Canadá para mayor seguridad ${ }^{763}$. Las invasiones y el establecimiento de unos reinos post-romanos con dificultades para mantener el orden facilitaron entonces las fugas.

Estas podían tener objetivos menos ambiciosos. Gregorio de Tours nos refiere el caso de Porciano, santo de origen servil que siendo esclavo de cierto bárbaro tenía por costumbre refugiarse en un monasterio, obligando a su abad a devolverlo ${ }^{764}$. La anécdota revela una práctica habitual, corroborada por los cánones de los concilios merovingios ${ }^{765}$ y por dos referencias en cartas de Ruricio de Limoges y de Avito de Vienne $^{766}$. Estas prácticas probablemente también contribuyeran a una relajación de las relaciones entre los aristócratas y sus dependientes. Debemos insistir en este punto en el carácter históricamente determinado de las relaciones de explotación. La esclavitud fue una institución con unas similares definiciones legales en la Grecia del siglo V a. C., en la Galia del s. VI d. C. o en las plantaciones del Nuevo Mundo, pero ello no quiere decir

\footnotetext{
${ }^{761}$ Sid., Ep., 2.1 (c. 470): 'Duo nunc pariter mala sustinent Arverni tui. 'Quaenam?' inquis. Praesentiam Seronati et absentiam tuam. [...] Totum quod concupiscit quasi comparat nec dat pretia contemnens nec accipit instrumenta desperans; in concilio iubet in consilio tacet, in ecclesia iocatur in convivio praedicat, in cubiculo damnat in quaestione dormitat; implet cotidie silvas fugientibus villas hostibus".

${ }^{762}$ C. J., 6.1 .3 (año 317-323): "Si fugitivi servi deprehendantur ad barbaricum transeuntes, aut pede amputato debilitentur aut metallo dentur aut qualibet alia poena adficiantur".

${ }^{763}$ Brion Davis 2006, 258.

${ }^{764}$ Greg. Tur., V. Pat., 5.1: "Beatissimus igitur Portianus ab ineunte aetate Deum quaerere caeli semper etiam inter terrena servitia conabatur. Hic enim servus fertur fuisse cuiusdam barbari. Idem cum plerumque ad monasterium confugiret, ut eum domino suo abba redderet excusatum, ad extremum fugiens, dominus eius de vestigio sequitur et abbatem calumniari coepit, reputans, quod ipse eum seduceret, ne sibi saus famulus deserviret. Cumque de consuetudine, ut eum redderet, calumniando abbatem insisteret, dicit abba Portiano: 'Quid vis, ut faciam?' Et ille: 'Redde', inquid, 'me excusatum'. Cumque excusatus redditus fuisset, et dominus eius reducere eum domi velit'.

${ }^{765}$ Conc. Orléans (511), c. 3; Conc. Épaône (517), c. 39; Conc. Orléans (541), c. 24 y 30; Conc. Orléans (549), c. 6 y 22. Estas disposiciones no refieren estrictamente a esclavos refugiados en monasterios, sino en la Iglesia en general. También buscaban asilo algunos libres, empujados por la necesidad: Conc. Orléans (541), c. 21.

${ }^{766}$ Rur., Ep., 2.20 (c. 490-500); Av., Ep., 44 (c. 499-516).
} 
que los vínculos entre amos y esclavos hayan tenido las mismas características en aquellas sociedades ${ }^{767}$.

Por último, debemos encarar la espinosa cuestión acerca de quiénes eran los fugados. Las fuentes no permiten hacer una evaluación profunda de su procedencia, si se trataba principalmente de domésticos, de trabajadores de la ciudad (artesanos, tenderos), de aquellos que trabajaban bajo vigilancia de un vilicus en las tierras de su amo o de tenentes (servi casati). Como hemos planteado en el capítulo precedente, es probable que la explotación de la tierra mediante un régimen de tenencia fuera mayoritaria en este periodo con respecto a la explotación centralizada. Por otro lado, la contracción de las ciudades (dramática desde el siglo V) produjo lógicamente la disminución de la cantidad de esclavos que desempeñaban funciones en dicho ámbito (y probablemente se redujera mucho más la presencia de artesanos y tenderos que de domésticos, pues parte de la aristocracia continuó teniendo un arraigo urbano) ${ }^{768}$. A partir de la documentación que se explaya con mayor o menor detalle sobre casos concretos de fugitivi -que hemos venido comentando-, pareciera que la iniciativa corría principalmente por cuenta de esclavos que convivían o tenían trato cercano con sus amos. Pero esto no es óbice para descartar la posibilidad de que los casati se fugaran, si nos apoyamos en la información -que también hemos citado- de huidas de coloni y de campesinos propietarios. Puede que aquí estemos enfrentándonos al problema de la disímil representación de los diferentes tipos de casos en la documentación.

\section{NUEVAS FORMAS DE OCUPACIÓN DE LA TIERRA}

\section{El fin de la villa}

El registro arqueológico da cuenta de un empobrecimiento material global para el siglo VI, de la casi desaparición de las villae y del desarrollo de nuevos núcleos de asentamiento rural donde se percibe o bien la ausencia de objetos que denoten una

\footnotetext{
${ }^{767}$ Con respecto a los esclavos romanos, su situación podía variar también en función de la ocupación que tuvieran (como domésticos, como artesanos o tenderos, como trabajadores agrícolas en regímenes de explotación directa, etc.). En la medida en que nuestro interés se centra en el ámbito rural en un periodo en el que es probable que fuera hegemónica la fragmentación de las propiedades de la elite en tenencias estos problemas pasan a un segundo plano. Véase Harper 2011, 100-200 para el periodo tardo-romano.

${ }^{768}$ Liesbeschuetz 2001, 82-89.
} 
diferenciación social sustancial o bien la presencia de restos materiales que indicarían la presencia de una elite laica o eclesiástica destacada más por su status que por su riqueza.

Aunque nuestro interés está enfocado en el área de la Galia que continuó bajo dominio imperial hasta bien entrada la segunda mitad del siglo $\mathrm{V}$, es necesario comenzar este apartado con un análisis espacio-temporal más abarcativo. Kim Bowes y Adam Gutteridge han criticado recientemente los planteos de Tamara Lewitt de que las transformaciones documentadas en las villae post-romanas no indicarían el reemplazo de elites por ocupantes pobres, sino el de la mutación de la apariencia material de una misma aristocracia que sobreviviría en términos sociológicos. Dichos cambios referirían a la conversión de espacios residenciales lujosos en espacios subdivididos de pobre calidad para funciones residenciales, artesanales, agrícolas o mortuorias y el gradual reemplazo de estructuras edilicias en ladrillo por otras hechas de piedra seca o madera. Estos nuevos espacios serían consistentes con una población agrícola viviendo en el nivel de subsistencia o superándolo apenas. Hasta aquí coincidimos con la argumentación ofrecida a partir de la crítica a Lewitt. Sin embargo, para Bowes y Gutteridge el cambio hacia formas de asentamientos aglutinados habría sido impulsado por una elite necesitada de manipular localmente a la población ante la incapacidad de mantener formas tradicionales de identificación asociadas a la adquisición de bienes importados ${ }^{769}$. En nuestra opinión, el establecimiento de esas nuevas formas de hábitat debió de obedecer a impulsos ajenos a la capacidad de control por parte de las aristocracias. Que estas luego se vieran en la necesidad de relacionarse según otras lógicas con esas aldeas en germen es una cuestión distinta.

Nos ocupamos ahora del midi galo. En Provenza, región desde la cual escribió Salviano, se constata durante los siglos IV y V la reocupación de numerosas villae por parte de campesinos. Muchas de las residencias rurales lujosas presentan signos de destrucción o deterioro en contextos de continuidad de ocupación, lo que lleva a pensar en su reconversión en simples granjas ${ }^{770}$. Estos datos cobran mayor relevancia si tenemos en cuenta que miembros de la aristocracia senatorial de la Galia del norte se instalaron en el sur durante dicho periodo ${ }^{771}$. Esa migración no logró revertir el proceso

\footnotetext{
${ }^{769}$ Lewitt 2003; Bowes y Gutteridge 2005. Sobre la desaparición de las villae en occidente, véase en general Ripoll y Arce 2001.

${ }^{770}$ Carru y otros 2001, 478.

${ }^{771}$ Drinkwater 1992, 213-214.
} 
en marcha, aunque podría explicar la mayor continuidad de las villae en el litoral de la región $^{772}$. Un sermón pronunciado por Cesáreo de Arlés en las primeras décadas del siglo VI nos presenta una denuncia similar a la que hiciera Salviano, en la que se tilda de moralmente reprobables ciertas maniobras vigentes mediante las cuales los ricos se apropiaban de las tierras de sus vecinos más pobres. El accionar desplegado incluía la confabulación con el poder público de quien quería realizar la expropiación, a fin de que el rigor del fisco se hiciera sentir con énfasis sobre la víctima elegida ${ }^{773}$. Esta práctica localizada demuestra la continuidad residual de las estructuras antiguas, incluida la del aparato tributario.

Como los documentos escritos, los restos materiales no hablan por sí solos. En este sentido, las posturas continuistas también se han apoyado en estos últimos para reforzar sus argumentos. Christophe Pellecuer y Hervé Pomarèdes han planteado, por ejemplo, que los resultados de los estudios micro-regionales de los últimos años del siglo pasado permitirían refrendar la tesis de la permanencia de los establecimientos dominiales durante la Antigüedad tardía, reinsertando a la villa dentro de la "red" (maillage) del hábitat rural. Sin embargo, los propios autores reconocen que la ocupación de villae de Narbonense I -región en la que centran su análisis- retrocede lentamente desde el siglo II d. C. hasta c. 450-500, cuando se acelera bruscamente. Esto es explicado como una "mutación del paisaje", frase que presenta como procesos naturales lo que son transformaciones sociales que en nuestra opinión se conectan con la

\footnotetext{
${ }^{772}$ Carru y otros 2001, 482.

773 Ces., Serm., 154.2: "Praegnans est, qui res alienas concupiscit: nutriens est, qui iam rapuit quod concupierat. Et ut hoc apertius etiam simplices intellegere possint, aliquam similitudinem proponamus. Concupiscit aliquis villam alienam, et dicit: bona est ista villa vicini mei: o si mea esset! o si adiungerem illam, et facerem de isto fundo et de illo unitatem! amat et avaritia unitatem: quod amat, bonum est, sed ubi amandum sit nescit. Si forte dives est vicinus ille, qui habet villam bonam, et suspicatur quod illam non possit tollere, quia potens homo est, et praevalet se contra illum defendere, nec concupiscit, nec inpraegnatur; nihil sperans non concipit, non est praegnans animo. Si vero iuxta aliquis vicinus sit pauper, qui vel in necessitate positus est ut possit vendere, vel potest obprimi ut cogatur vendere, inicitur oculus, sperat se posse tollere aut villam aut colonicam vicini pauperis, et inmittit illi aliquas tribulationes: verbi gratia, agit secretius apud eos qui possunt, ut illum exactores aut faciant inplicatum, aut allectum in aliqua publica et damnosa administratione constringant; ex quibus contractis debitis multis necesse habeat infelix vendere casellam, unde aut ipse aut filii sui sustentabantur. Necessitate ergo conpulsus venit ad illum, per cuius nequitiam premitur et adfligitur; et nesciens quod ipsius inmissione hoc patitur, dicit ad eum: da mihi, domine, rogo te, paucos solidos; patior necessitatem, urgeor a creditore. Et ille: non habeo modo in manibus. Ideo se dicit in manibus non habere, ut ille obpressus calumnia necesse habeat vendere. Denique cum ei dixerit, quod pro nimia adflictione sua conpellatur villam distrahere, statim ille respondet: et si non habeo pecuniam propriam, undecumque studeo mutuare, ut tibi amico meo subveniam; et si ita necesse est, etiam argenticulum meum distraho, ne tu iniuriam patiaris. Quando beneficium petebat, professus est penitus non habere: at ubi dixit quod possessionem suam venderet, quasi amico subvenire se dicit; et cum eum ad hanc necessitatem adduxerit, dicit illi ut venditionem facere debeat, et casellam, pro qua prius verbi gratia forte centum solidos offerebat, ut eum opprimi viderit, nec medietatem pretii dare adquiescit".
} 
argumentación que venimos planteando, o bien como un "cambio cultural" sobre cuyo origen no se profundiza. La reocupación es susceptible de ser interpretada como núcleos campesinos bajo dominación débil -inspirándonos en los planteos de Bowes y Gutteridge- y no como dominios según proponen Pellecuer y Pomarèdes. Este es el punto en el que la documentación escrita permite arrojar luz sobre el material arqueológico. Finalmente, como en Provenza, la región narbonense presenta diferencias internas que oscilan entre la ruptura brusca y el declive lento, pero en forma alguna hay evidencia de estabilidad o crecimiento de sus villae. Además está atestiguada en la región la aparición de nuevos núcleos de asentamiento, como veremos ${ }^{774}$.

Es preciso ahora volver sobre la explicación "cultural” de las transformaciones percibidas en el registro arqueológico, que constituye el núcleo de argumentos como los de Lewitt. La cuestión puede derivar fácilmente en el dilema del huevo o la gallina: ¿es el fin de una forma de ostentación del status producto de la incapacidad de sostenerlo, o bien el empobrecimiento material es consecuencia de una "militarización" derivada a su vez de los cambios políticos del periodo? Wickham plantea que la mutación en el hábitat rural y específicamente en las prácticas edilicias de la elite del norte franco pudo haber sido producto de transformaciones identitarias ${ }^{775}$. Sin embargo, como indica Laura da Graca, el autor incurre en una contradicción al proponer, al mismo tiempo, que la aristocracia merovingia vivía en palacios -que no han sido descubiertos aún por los arqueólogos-; vale decir que considera que el tipo de residencia continúa expresando la diferenciación social y que la forma de manifestación del status no habría cambiado durante la temprana Edad Media ${ }^{776}$. Sidonio envió en el año 472 o 473 una carta a su amigo Aper preguntándole cuándo regresaría a la ciudad y si estaba pasando el tiempo en los baños de Baiae o acampando en los castella de las montañas en busca de refugio $^{777}$. La epístola es reveladora de las transformaciones que estamos analizando. Algunos miembros de la aristocracia continuaban teniendo una residencia urbana y aferrándose a un modo de vida tradicional (el otium en las partes urbanas de sus villae), pero esta era una realidad cada vez más difícil de mantener. En otra carta, elogia a Elafio por haber concluido -después de un largo tiempo- la construcción de un

\footnotetext{
${ }^{774}$ Pellecuer y Pomarèdes 2001.

${ }^{775}$ Wickham 2005, 476-477, 486 y 506-507.

776 da Graca 2008, 293-294.

777 Sid., Ep., 5.14: “Calentes nunc te Baiae et scabris cavernatim ructata pumicibus aqua sulpuris atque iecorosis ac phthisiscentibus languidis medicabilis piscina delectat? An fortasse montana sedes circum castella et in eligenda sede perfugii quandam pateris ex munitionum frequentia difficultatem?".
} 
baptisterio en tiempos en los que otros apenas tienen el coraje de reparar los existentes $^{778}$. Aunque se trate en este caso de un edificio eclesiástico, las palabras de Sidonio revelan las dificultades materiales que tenían los obispos para continuar ejerciendo el poder en la forma en la que tradicionalmente lo habían hecho: mediante la construcción $^{779}$. La militarización de la aristocracia se produjo y lo cambios culturales existieron, pero no es este el lugar para analizar estas cuestiones en profundidad. Lo que pretendemos destacar en todo caso es que los cambios en las formas de identificación de las elites estuvieron íntimamente relacionadas con su incapacidad para extraer productos del campesinado con los cuales sostener las formas tradicionales de ostentación del status: edificios en piedra o ladrillo, bienes de lujo, etc. Por otro lado, la militarización no es por sí misma una explicación satisfactoria de, por ejemplo, la aparición de la construcción de residencias aristocráticas en madera. Jean-Pierre Sodini ha sostenido que los miembros de alto rango del ejército habitaron en edificios lujosos similares a los de la aristocracia laica durante el periodo tardo-romano. El mismo argumento se sostiene con respecto a las residencias de las jerarquías eclesiásticas de la época, de modo que tampoco la cristianización podría ser esgrimida como factor explicativo de los cambios que vienen analizándose ${ }^{780}$.

\section{Los nuevos núcleos}

En Provenza y Languedoc reaparece con cierta importancia la ocupación de sitios de altura y fortificados, a menudo sobre antiguos oppida pre-romanos. Según los expertos, el estado actual de los conocimientos no está lo suficientemente desarrollado como para realizar una síntesis o comparaciones con otras regiones, aunque los datos disponibles permiten extraer algunas conclusiones. En primer lugar, hay reocupaciones que se remontan al siglo $\mathrm{V}$ y tienen continuidad en el VI e incluso en el VII, que presentan claros signos de presencia aristocrática. Este dato es interesante y podría relacionarse con información documental sobre sectores de la aristocracia que se estaban desligando de la civitas $^{781}$. Otros sitios fortificados -que datarían de fines del siglo IV- revelan que allí hubo construcciones eclesiásticas. Laurent Schneider los ha

\footnotetext{
${ }^{778}$ Sid., Ep., 4.15.1: "Siquidem res est grandis exempli eo tempore a vobis nova ecclesiarum culmina strui, quo vix alius auderet vetusta sarcire".

${ }_{779}$ Rapp 2005, 264-265.

${ }^{780}$ Sodini $2003,33$.

${ }^{781} \mathrm{Sid} .$, Ep., 1.6 (467), 2.2 (461/467), 7.15 (c. 470) y 8.8 (474).
} 
vinculado con el proceso de organización de la Iglesia y el traslado de la prefectura de las Galias a Arlés ${ }^{782}$, priorizando una explicación fundamentada en la reorganización administrativa y la implantación de las estructuras eclesiásticas por sobre la tesis tradicional que relacionaba este tipo de ocupación con huidas en el marco de las invasiones bárbaras o la depresión económica. Sin embargo, el propio Schneider reconoce que la ocupación de sitios de altura no concierne solo a un tipo de hábitat campesino $^{783}$. En nuestra opinión, podría pensarse que muchos de ellos fueron asentamientos nucleados de campesinos libres o sometidos a un leve tutelaje por parte de autoridades laicas o eclesiásticas. Esto no implica adscribir a las tesis tradicionales sobre los efectos inmediatos de la conquista (la ocupación de oppida como refugio).

Otro fenómeno del periodo en la Galia mediterránea es la ocupación de grutas, antaño también interpretado como efecto de las calamidades bélicas y económicas del bajo imperio. Claude Raynaud ha calificado esta tesis de argumento circular: se parte de la suposición -fundada en fuentes escritas- de que hubo huidas de población, para constatarla en los restos materiales de ocupación de grutas. Esta crítica se encuadra dentro de las corrientes que en la Arqueología amonestan a quienes van a buscar en los restos materiales objetos que ilustren la Historia ${ }^{784}$. Pero a pesar de que este argumento tiene razones de fuerza, encierra la idea de que el plano de la documentación escrita y el de los restos materiales no pertenecen a una misma realidad histórica. Una cuestión parece incontestable en cuanto a la información brindada por las prospecciones: la ocupación de grutas asciende bruscamente en los siglos V y VI, para luego descender con mayor fuerza aún. Debe darse alguna interpretación sobre estos datos. Raynaud desestima la teoría de que se traten principalmente de refugios, planteando la existencia de grutas utilizadas como santuarios, talleres artesanales, abrigo para poblaciones pastoriles y hábitat de eremitas. Su balance, provisorio a fuerza de la precariedad de la información disponible hasta el momento, se inclina por la diversidad de móviles en la ocupación de estos espacios. Nuestro aporte a la cuestión sería repensar el concepto de "refugio" en términos más amplios, no circunscriptos a la huida de los bárbaros, sino referentes a la búsqueda de nuevos espacios independientes por parte de campesinos y como variable compatible con las distintas formas de ocupación de grutas enumeradas

\footnotetext{
${ }^{782}$ Incluso un número considerable de ellos se convirtieron luego en centros administrativos en tiempos carolingios.

${ }^{783}$ Schneider 2001.

${ }^{784}$ Véase Lavan 2003, xiii.
} 
por el autor ${ }^{785}$. A juzgar por los trabajos de este último y de Schneider, parecería que en el esfuerzo por criticar las tesis "catastrofistas" que vinculaban la ocupación de grutas o antiguos oppida con las invasiones, ciertos arqueólogos han sido incapaces de pensar la posibilidad de que el fenómeno pueda ser explicado a partir del proceso más general de debilitamiento de las aristocracias y liberación del campesinado.

Estas pautas que hemos delineado se constatan en otras regiones del sur, como en el valle medio del Ródano, corazón del reino burgundio en el periodo post-romano. Allí también se ha detectado la reocupación de antiguos oppida de altura en forma de hábitats concentrados y la ocupación temporal de grutas y de edificios abandonados. Benoit Ode y Thierry Odiot han desestimado la vinculación directa entre estos últimos y los fugitivi, a pesar de que la relación es sugestiva y se ajusta al contexto ${ }^{786}$. En cuanto a los hábitats concentrados, cabe destacar que algunas prospecciones han descubierto la presencia de recintos amurallados y residencias más prósperas que otras ${ }^{787}$, lo que podría interpretarse como comunidades con desigualdad interna, algo que tampoco desentona con los resultados arrojados para otras regiones.

\section{Cambios en el hábitat rural y expansión del campesinado independiente}

Queremos cerrar este apartado haciendo hincapié en un aspecto central para la historia de occidente: la transformación de un hábitat rural caracterizado por el dominio de la propiedad fundiaria (representado por la villa) a uno hegemonizado por aldeas que funcionaban como centros de territorios ${ }^{788}$. Este proceso también se dio, con ritmos diferenciados, en toda la Europa occidental temprano medieval ${ }^{789}$. En palabras de JeanPierre Devroey, “[e]l paisaje característico de los pueblos merovingios es el de un asentamiento compuesto de pequeñas aldeas dispersas, con una multitud de campos pequeños separados por tierras sin cultivar, 790 .

\footnotetext{
${ }^{785}$ Raynaud 2001.

${ }^{786}$ Ode y Odiot 2001, 227.

${ }^{787}$ Ode y Odiot 2001, 230-232.

${ }^{788}$ Wickham 2001, 566-567. Esto no implica negar la existencia de aldeas en occidente en época romana, sino otorgarle un rol marginal con respecto a las granjas aisladas y las villae aristocráticas. Sobre el tema, véase Ward-Perkins 2000a, 332-333.

${ }^{789}$ Wickham 2005, 470.

${ }^{790}$ Devroey 2002, 112.
} 
Lo anterior implica revisar la tesis de que la aldea había aparecido en el año 1000, propuesta por Jean Chapelot y Robert Fossier en $1980^{791}$. En nuestra opinión esto se relaciona íntimamente con una crisis de la clase dominante romana. El cambio tuvo su génesis en un periodo caracterizado por desarrollos ambiguos que hemos intentado reflejar en el capítulo anterior. Si durante un tiempo se mantuvieron las relaciones de dependencia heredadas y se gestaron nuevas a partir de la desintegración de pequeñas propiedades de campesinos, pronto los vínculos de explotación comenzaron a relajarse, haciendo surgir núcleos independientes que contribuirían más adelante a la formación de una sociedad de base campesina, ya en pleno siglo VI. Hubo un periodo de solapamiento, pero la primera de estas lógicas evolutivas fue progresivamente marginada por la segunda, lo cual, insistimos, supuso la pervivencia de formas residuales de explotación "antigua" de coloni y servi, incluso micro-regionalmente relevantes ${ }^{792}$. El hecho de que estas últimas estén mejor documentadas que el campesinado relativamente independiente no debe hacernos caer en el frecuente error de confundir la parte con el todo.

Creemos que existe una conexión entre la transformación del hábitat y la emergencia de un campesinado independiente. En el capítulo 3 recogimos la interpretación de Matthew Innes respecto al proceso de transferencia de la propiedad territorial en el reino burgundio de manos romanas a manos bárbaras. En ese mismo trabajo el autor plantea que el reconocimiento en las leyes burgundias de derechos de los romanos sobre parte de las tierras de su propiedad roturadas por los burgundios evoca un hábitat en proceso de transición, que como hemos visto puede constatarse en el registro arqueológico ${ }^{793}$. Cabría pensar la hipótesis de que quienes se apropiaran de estas tierras no fueran únicamente (ni siquiera principalmente) miembros de las aristocracias germánicas sino campesinos de diversos orígenes, muchos de ellos autóctonos, que comenzaron a servir en los ejércitos de estos nuevos reinos y que como consecuencia de ello pasaron a ser burgundios (o francos o godos) por un proceso de etnogénesis. Todo ello no excluye que miembros de las propias aristocracias también dejaran de ser romanos al militarizarse, como bien plantea Innes.

\footnotetext{
${ }^{791}$ Citado en Zadora-Rio 2009, 77.

${ }^{792}$ Pequeñas "manchas" dentro de un universo campesino que Wickham $(2005,535-551)$ representa apelando a la imagen de la piel de un leopardo.

${ }^{793}$ Innes 2006, 72.
} 


\section{ARISTÓCRATAS DÉBILES Y CAMPESINOS INDEPENDIENTES}

El campesinado ganó independencia con el transcurso de la coyuntura abierta hacia mediados del siglo V. Hemos señalado ya lo difícil que resulta determinar su importancia. Contamos con un poco más de información para periodos posteriores. Sabemos que en la región contenida entre el río Loira y los Pirineos dominó entre los siglos VI y VII el alodio campesino o las tenencias gravadas con rentas poco elevadas, como el agrarium o la tasca, del orden del décimo de los cereales cosechados. Para Devroey, el testamento de Abbon (739) y los polípticos de Mauriac y Marsella hacen pensar en un señorío rentista con mano de obra esclava y una clientela de pequeños campesinos, herederos de los colonos o servi casati. Estaríamos en presencia de sociedades campesinas menos autónomas, más directamente encuadradas por los agentes locales del señorío y directamente amenazadas por los abusos de poder de las elites $^{794}$. De cualquier forma esto no invalidaría que el punto de partida de esta realidad propia del siglo VIII fuera una mayor autonomía en los siglos VI-VII, hecho que se reflejaría en los bajos niveles de renta señalados. El mismo autor plantea en otro trabajo que el siglo VIII ve la puesta en marcha de nuevas formas de ingreso por iniciativa real: impuestos elevados por no acudir al ejército; introducción de corveas para el rezo del señor; difusión del diezmo parroquiano ${ }^{795}$.

El Estado y la aristocracia, laica o eclesiástica, encontraron serias dificultades para encuadrar una explotación estable. Ya nos hemos referido a la debilidad del impuesto. La Iglesia, por su parte, halló obstáculos durante el siglo VI para retener bienes que le eran donados. Se dispusieron repetidamente en los concilios galos medidas tendientes a impedir que las propiedades que eran ofrecidas a la Iglesia fueran reclamadas por terceros ${ }^{796}$. Esto incluía seguramente tierras de los campesinos. El concilio de Orléans de 549 es muy claro en sus canon 16: las disposiciones valen tanto para los grandes como para los humildes (maiorum aut mediocrum personarum) ${ }^{797}$. Por

\footnotetext{
${ }^{794}$ Devroey 2003, 298

${ }^{795}$ Devroey 2005, 339.

${ }^{796}$ Véanse e. g. los concilios de Clermont (535), c. 14; Orléans (541) c. 14 y 19; París (556-573), c. 1; Lyon (567-570), c. 2; Mâcon (581-583), c. 4.

797 Conc. Orléans (549), c. 16: "Quisquis etiam maiorum aut mediocrium personarum quodcumque muneris vel facultatis sacerdotibus aut exxclesiis aut quibuslibet locis sanctis studio mercedis cum iustitia
} 
otro lado, tenemos datos de monjes que se veían obligados a labrar la tierra solo con sus manos o junto a sus escasos dependientes. Los Statuta ecclesiae antiqua aconsejaban al clero menor ganarse la vida cultivando o practicando un oficio ${ }^{798}$ : ¿era esto hacer de la necesidad virtud? La misma pregunta cabe formularse acerca del caso de Niceto, obispo de Lyon de orígenes senatoriales, quien por razones religiosas -según Gregorio de Tours- vivió en casa de su madre una vez que enviudó, trabajando a la par de los esclavos $^{799}$. El canon 8 del concilio de Épaône de 517 prohibía a los abades la manumisión de los esclavos donados a los monjes, pues estimaba injusto que estos últimos se encargaran de los quehaceres agrícolas mientras los primeros gozaban del ocio de la libertad $^{800}$. Cabe preguntarse si la necesidad de fuerza de trabajo en los monasterios podría explicar en parte la popularidad de la regla de Juan Casiano a comienzos de la Edad Media. Marilyn Dunn nos recuerda que Gregorio de Tours, Gregorio Magno, Casiodoro y Benito de Nursia recomendaban su lectura. Sus Instituciones hacían mucho hincapié en la prescripción laboral a los hermanos de los cenobios $^{801}$. Recordemos que Lupicio y Romano tuvieron que trabajar la tierra con sus propias manos en los inicios de Condat en los Jura, alrededor del año 435; años después, rechazaron el ofrecimiento de campos y viñedos por parte del rey Chilperico, pero en cambio le solicitaron sus frutos, hecho que podría deberse a que no tenían forma de explotarlos $^{802}$. Por último, la incapacidad de la Iglesia para sostener relaciones de dominación estables sobre su feligresía se evidencia en sus frustrados intentos por universalizar el pago del diezmo ${ }^{803}$.

pro Dei contemplatione contulerit aut ea, quae a parentibus donata noscuntur, postmodum auferre praesumpserit, superiori sententia ut necator pauperum a communione privabitur".

${ }_{798}$ Klingshirn 1994, 79.

${ }^{799}$ Greg. Tur., V. Pat., 8: "Defuncto antem patre, hic cum genetrice iam clericus in domo paterna resedens, cum reliquis famulis manu propria laborabat, intellegens, commotions corporeas non aliter nisi laboribus et aerumnis obpremi posse".

800 "Presbyter dum diocesim tenet, de his quae emerit aut ecclesiae nomine scripturam faciat aut ab eius quam tenuit ecclesiae odinatione discedat. Similis quoque de venditionibus, quas abbates faccere praesumserint, forma servabitur, ut quidquid sine episcoporum notitia venditum fuerit, ad potestatem episcopi revocetur. Mancipia vero monachis donata ab abbate non liceat manumitti; iniustitum enim putamus, ut monachis cotidianum rurale opus facientibus servi libertatis otio potiantur".

${ }^{801}$ Cass., Inst. 2.5, 2.12-15, 3.2, 4.12, 4.14, 5.38, 7.7, 7.16-19, 9.1, 10.2, 10.8, 10.19, 10.22-24, 11.11, 11.13; Dunn 2000, 81.

${ }^{802}$ Greg. Tur., V. Pat., 1.2: "Cumque iam beati heremitae populis, ut diximus, publicati fuissent, fecerunt sibi monasterium, quod Condatiscone vocitari voluerunt, in quo, succisis a silvis et in plana redactis, de laboribus manuum propriarum victum quaerebant"; 1.5: "Rex vero haec audiens, ait: 'Accipite agros vineasque, de quibus possetis vivere ac necessitates vestras explere'. Qui respon dit: 'Agros et vineas non accipiemus, sed, si placet potestati vestrae, aliquid de fructibus deligate. Quia non decet, monachos facultatibus mundanis extolli, sed in humilitate cordis Dei regnum iustitiamque eius exquerere"'.

${ }^{803}$ Ello ocurriría durante el siglo IX (Devroey 2006, 452). 
La propia aristocracia era un grupo sumamente inestable. Casi todos los funcionarios de rango de los siglos VI y VII mencionados por Venancio Fortunato, Gregorio de Tours o Fredegario perdieron la vida y/o su cargo poco después de haber accedido a las altas esferas del poder ${ }^{804}$. Como plantea Devroey, el hecho de que durante la temprana Edad Media el discurso social ignore la idea de que una función civil podía conferir ennoblecimiento confirma la hipótesis de que la nobleza constituía un grupo fluido, con fronteras vagas. Por ello no existía la figura retórica del "hombre nuevo" $" 805$.

Recordemos una vez más que esto no supuso la desaparición de la explotación en el seno de las grandes propiedades. Fréderic Trément ha planteado la hipótesis de que durante los dos últimos siglos de gobierno imperial se produjo un enrarecimiento de las villae en un contexto de continuidad de los dominios rurales, pero Dominique Carru, Fabienne Gateau, Philippe Leveau y Nadège Renaud han sostenido que pese a que es evidente la presencia de grandes propiedades en la región y periodos analizados, no es posible hablar de continuidad en la economía dominial ${ }^{806}$. Esta postura resulta más convincente a juzgar, como veremos, por los signos generales de empobrecimiento material.

El fenómeno más general de relajación de los vínculos de dependencia obligó a unas elites en proceso de transformación a plantear nuevos vínculos con un campesinado ahora cada vez más libre. Una forma de construir liderazgo se dio a través del accionar de los santos. Sabemos que las autoridades eclesiásticas alentaron su culto una vez muertos; les atribuyeron la capacidad de curar, exorcizar demonios, asegurar la fertilidad de los campos y defender a los fieles ${ }^{807}$. Pero tomemos el ejemplo de un beato vivo, proveniente de una región adyacente a la de nuestro interés. Gregorio de Tours relata la historia de Senoch, quien se convirtió en patrono de cientos de hombres al liberarlos de la esclavitud y las cárceles. En ese rol, ayudó a sus clientes a construir puentes y otras obras para frenar inundaciones, hecho que le permitió convertirse en un clérigo localmente distinguido ${ }^{808}$. El caso es por demás interesante porque pone en evidencia la forma de construir poder a partir de la reciprocidad.

\footnotetext{
${ }^{804}$ Devroey 2006, 127.

${ }^{805}$ Devroey 2006, 106.

806 Trément 2001; Carru y otros 2001.

807 Jones 2011, 89-90.

${ }^{808}$ Greg. Tur., V. Pat., 15.1: "Conferebat ei devotio fidelium plerumque pecuniam, sed non eam in abditis loculis, sed in paupe rum marsupiis condebat, illud dominici eloquii oraculum saepe commemorans:
} 
Otra forma de construir liderazgo, propia de las aristocracias laicas, fue la conformación de comitivas armadas. Recordemos una vez más que la guerra fue una realidad cotidiana durante el periodo estudiado. La caída del Estado romano supuso la desaparición del ejército profesional financiado por el aparato fiscal y su reemplazo por uno campesino. Ya hemos analizado la vinculación entre los reyes y las aristocracias en las expediciones militares. La misma lógica de reparto de los despojos se dio entre soldados rasos y comandantes. Los jefes militares se embarcaban continuamente en campañas de corta duración en busca de botín. Como hemos visto en el capítulo 3, existían además bandas armadas que en tiempos de guerra se incorporaban a los ejércitos, pero que en tiempo de paz se dedicaban al pillaje. Diego Santos se apoya en la interpretación más general de Guy Halsall para estudiar el caso galo e ilumina la cuestión de nuestro interés:

El ejército campesino no implicó el aumento del número de combatientes de los ejércitos sino, por el contrario, la multiplicación de mesnadas reducidas. Se debía recurrir al aprovisionamiento sobre el propio terreno, lo que implicó que cada campaña militar tuviera que ser al mismo tiempo una incursión en búsqueda de rapiña. Guy Halsall piensa que hay que abandonar el uso de números de tropas dados por las fuentes.Un ejército de 5000 personas representaba cien veces la población de los asentamientos rurales. Los intereses de un comandante debieron haber sido levantar un número pequeño de tropas bien equipadas y llevarlas a un territorio hostil lo más rápidamente posible. 5000 o 6000 combatientes representan para él la cifra máxima de una fuerza militar capaz de ser mantenida, a los que habría que añadir un número de sirvientes no guerreros ${ }^{809}$.

Es posible entonces que la militarización de las aristocracias implicara un nuevo tipo de acercamiento con un campesinado que ahora podía protegerse mejor al estar armado. Retomando nuevamente a Santos: "la posibilidad de los campesinos libres de sumarse a bandas reducidas provocó que su capacidad para resistir a la extracción de su excedente por parte de las autoridades distritales exacerbara los conflictos entre los

\footnotetext{
Nolite thesaurizare vobis thesaurum super terram, quia, ubi fuerit thesaurus tuus, illic erit et cor tuum. Dabat enim hic quae accipiebat pro Dei intuita in diversis necessitatibus indigentum. Unde factam est, ut in vita sua de his amplius quam ducentos a nexu servitutis debitique onere sublevasset". [...] Omnes enim quoscumque per eum a diversis infirmitatibus dextera divina salvavit, si inopes fuissent, ipse cibum vestitumque dispensatione hilari porregebat; tantaque ei cura de aegentibus fait, ut etiam pontes super alveos amnium diligenter instrueret, ne quis, inundantibus aquis, naufragia saeva lugeret".

${ }^{809}$ Santos 2011, 162.
} 
poderosos, quienes los movilizaron para conseguir botín a expensas de otros" ${ }^{\text {810 }}$. Pero también los servi parecen haber formado parte de las comitivas armadas ${ }^{811}$.

Una última reflexión en torno a estas cuestiones. En un trabajo reciente Allen Jones caracteriza como "estrategias" las distintas vías a través de las cuales tanto la elite como los grupos "no aristocráticos" (ingenui, pauperes, servi) perseguían el ascenso social. Las prácticas que hemos venido comentando quedarían incluidas dentro de esta conceptualización, como vínculos clientelísticos sellados de común acuerdo entre grupos subalternos y miembros de la elite para beneficio de ambas partes. No negamos la operatividad de la noción de "estrategia", que puede ayudar a comprender, por ejemplo, las alianzas matrimoniales que establecían las familias más encumbradas en busca de mejoramiento de su posición social. Sin embargo, puede llevarnos a la idea errada de que la aristocracia imponía y controlaba los vínculos con los grupos inferiores, pues estos competían entre sí para ganarse su favor. Jones da cuenta, por ejemplo, de una serie de casos documentados de servi que escalaron posiciones en la Iglesia o en la corte. En contraposición a esto, hemos hecho notorio en esta tesis el hecho de que los esclavos se fugaban constantemente. En tal sentido, la reunión de algunas o varias referencias a pauperes y servi que ascendieron socialmente podría llevar a la equivocada conclusión de que este fue un derrotero más extendido del que en general se cree y que incluso la movilidad social era fluida ${ }^{812}$. En nuestra opinión los intereses inmediatos de la mayor parte de los grupos "no aristocráticos" eran distintos a los que Jones propone. El carácter endémico de la violencia no era meramente el producto de las querellas entre miembros de la elite, sino también de una "multiforme lucha social", como plantea Carlos Astarita ${ }^{813}$. Insistimos entonces en que el fenómeno del clientelismo podría entonces ser pensado no tanto como un acuerdo entre un servus o un pauper que buscaba ascender socialmente y un aristócrata que accedía a ser su patrono, sino más bien a partir de la incapacidad por parte de la elite de establecer relaciones de dependencia con buena parte del campesinado y los sectores urbanos inferiores y de la consecuente necesidad de plantear vínculos de relativa reciprocidad. Si en Salviano veíamos a campesinos obligados a someterse a un tipo de patronazgo que encubría una

\footnotetext{
${ }^{810}$ Santos 2011, 163.

${ }^{811}$ Rio 2009, 227.

812 Jones 2011, 338-339.

${ }^{813}$ Astarita 2007, 259.
} 
relación de explotación, ahora vemos a miembros de la aristocracia que deben apelar a la reciprocidad para reconstruir su poder social.

\section{CONTRACCIÓN ECONÓMICA Y DEBILIDAD ARISTOCRÁTICA}

Hemos hablado anteriormente de los efectos económicos negativos de este estado de guerra permanente. Pero la simplificación de la vida material se relaciona de una forma más estructural con la referida debilidad de los lazos de dominación, con la incapacidad por parte de las aristocracias y de los Estados de extraer un excedente estable de la población campesina.

Existe actualmente cierto acuerdo entre los académicos en lo que respecta a los rasgos medulares de la realidad material de la Europa occidental temprano medieval. Para Michael McCormick, por ejemplo, se perciben dos procesos fundamentales a fines de la Antigüedad a través de los hallazgos arqueológicos: una disminución en la densidad de los asentamientos (hay una menor cantidad de sitios poblados encontrados) y las últimas etapas del flujo de la cerámica africana y oriental a los rincones de la Europa occidental que aún se hallaba integrada en el mundo del Mediterráneo. En su opinión hay una contracción económica general en el periodo c. 200-c. 700 que se origina en el noroeste del continente y se extiende progresivamente hacia el este y el sur. Se apoya en estudios sobre la extracción de metales y la producción artesanal para fechar el inicio de la declinación económica en Europa occidental hacia el siglo V. El elemento primordial es en su opinión el descenso demográfico, pero ello llevaría a pensar que se trata de un problema de magnitud de la producción y de los intercambios. Como bien ha planteado Bryan Ward-Perkins, no se trata de una simple contracción como si la economía del siglo VII fuese similar a la del IV pero en una escala reducida-, sino de un importante cambio cualitativo en la vida material. Grandes áreas de especialización e intercambio desaparecieron e incluso, en algunas regiones, la tecnología básica dejó de existir ${ }^{814}$.

Es similar la caracterización de la economía hecha por Chris Wickham para los años 400-800. En su opinión existen tres grandes regiones -el norte, el Mediterráneo

${ }^{814}$ McCormick 2001, 29-33 y 42-61; Ward-Perkins 2000b, 361. 
occidental y el Mediterráneo oriental- que tienen procesos históricos diferentes. Plantea que en la segunda de estas geografías se habría producido una simplificación de las estructuras económicas y que las elites se habrían vuelto más pobres. El cuadro general no excluiría, por otra parte, diversidades regionales (como hemos visto este autor permanece seducido por las interpretaciones de las últimas décadas que ven una fuerte continuidad en el poder de la antigua aristocracia senatorial de la Galia meridional durante el periodo merovingio) ${ }^{815}$.

En este sentido, Devroey caracteriza acertadamente a la sociedad del periodo post-romano como relativamente pobre e indiferenciada desde el punto de vista material; de allí que la riqueza del ornamento se convirtiera en un signo de distinción muy importante ${ }^{816}$. En este punto, el autor se aleja junto a nosotros de la postura de Wickham. Considera que debería ubicarse hacia mediados del siglo VI el punto de mayor hundimiento de un proceso de crisis general en el occidente europeo. La documentación escrita y arqueológica permite constatar un cuadro de depresión agrícola, solución de continuidad entre el hábitat antiguo y medieval, escasa ocupación del suelo, degradación marcada de la salubridad, fuerte impacto de las epidemias, frecuencia de las crisis. Son estos atributos centrales de un periodo marcado por un "regreso a la naturaleza". La nueva valorización de lo inculto y del mundo salvaje que se desarrolla en la temprana Edad Media -y que es ajena a la urbanidad antigua-estaría íntimamente relacionado con estos cambios ${ }^{817}$.

Entre los tantos signos de pobreza material, podemos destacar a modo de ejemplo el de las fortificaciones. Durante los primeros siglos medievales hay una ausencia palmaria de defensas en los asentamientos rurales, incluso en las propiedades aristocráticas. Esto difícilmente pueda ser considerado una elección en un periodo en el que, insistimos, la guerra era una realidad cotidiana. Las fuentes nos hablan de mal estado y colapsos en las murallas existentes en las ciudades. Hay que esperar hasta el siglo IX, con ocasión de los ataques de vikingos y árabes, para encontrar una reconstrucción sistemática de las fortificaciones ${ }^{818}$. El contraste con los siglos III-IV es en este sentido ostensible. Fueron extendidas las tareas de construcción de defensas en

\footnotetext{
${ }^{815}$ Wickham 2005, 169-204, 721-759 y 820-823. Véanse las referencias a las interpretaciones continuistas en el capítulo 1.

${ }^{816}$ Devroey 2003, 213.

${ }^{817}$ Devroey 2003, 33-48, 213 y 312. Un cuadro similar ya era planteado por Fourquin (1975, 320-338) y Doehaerd (1974, 9-194).

${ }^{818}$ Halsall 2003, 215-218. Greg. Tur., Hist., 2.37; Fred., Chron., 2.60.
} 
la Galia entre el gobierno de Diocleciano y la muerte de Teodosio I, hecho que sugiere que la región contaba con excedentes sustanciales de recursos humanos, materiales y animales para sostener la empresa ${ }^{819}$.

Por otro lado, la retracción general de la economía tuvo su impacto en la circulación de bienes. Trataremos aquí de forma indistinta el comercio y los intercambios no comerciales, no porque desestimemos la importancia de la diferencia entre la circulación de productos a través del mercado y por fuera del mismo, sino porque en el presente estudio nuestra atención está puesta en cómo la circulación -del tipo que sea- evidencia la producción de excedentes. Vale decir que nos interesa analizar qué tipos de bienes se intercambiaban y en qué magnitud (si es que esto último se puede ponderar) ${ }^{820}$.

Los intercambios dependieron de la capacidad de las aristocracias y de los Estados para extraer excedente de los campesinos y no de factores políticos puntuales como pretendió Pirenne ${ }^{821}$. Durliat da cuenta de la disminución del flujo mercantil de alcance regional y de larga distancia (no así del local) para el siglo VI en el mar Mediterráneo. Esto habría sido producto de un descenso en la demanda proveniente de la elite, pero la atribuye a una tendencia hacia a la autarquía productiva y no a una incapacidad para costear productos como es nuestro parecer. Por otra parte, en su opinión habría continuado existiendo una importante circulación de bienes en forma de impuestos que los súbditos pagaban al Estado, algo que, como hemos visto en el capítulo 4, resulta a juicio nuestro difícil de sostener para los reinos germánicos ${ }^{822}$. Parece acertada, en cambio, la interpretación de Wickham, quien asocia el colapso del sistema de intercambios centrado en la hegemonía africana con el del sistema fiscal en occidente $^{823}$. La continuidad de los intercambios a través del Mediterráneo durante los

\footnotetext{
${ }^{819}$ Bachrach 2010. La incapacidad del Estado para afrontar obras públicas no se circunscribía a las defensas urbanas. En Nîmes y en Arlés, por ejemplo, han sido detectados arreglos en los acueductos durante el siglo IV e incluso a comienzos del V, pero se sabe que para el VI el uso de aquellos se detiene y pasan a servir de cantera (Fixot 2000, 48-49). Recordemos, por otro lado, la carta de Sidonio citada más arriba en la que se ponía de manifiesto el esfuerzo de muchos eclesiásticos para hacer frente a la refacción edilicia (Ep., 4.15.1).

${ }^{820}$ Sobre esta distinción véase Whittaker [1983] y, especialmente, Wickham 2005, 694-707. Es conocido el debate entre primitivistas y modernistas en lo concerniente al comercio y los intercambios en el mundo de la Antigüedad clásica. Véase la presentación de la cuestión por parte de Peter Bang (1997) y su interesante comparación del comercio romano con el bazar indio, un tipo de mercado caracterizado por la incertidumbre, la impredictibilidad y la segmentación, en el que los actores involucrados buscan dominar los altos niveles de riesgo (2006).

${ }^{821}$ Pirenne [1935].

${ }^{822}$ Durliat 1998.

${ }^{823}$ Wickham 2005, 713.
} 
siglos VI-VII más bien debería de vincularse a la continuidad de la estructura imperial romana en oriente, que por sí sola mantenía los medios y el motor para el transporte de bienes entre regiones ${ }^{824}$.

En lo que respecta a los intercambios para la Galia meridional, los estudios arqueológicos no son todavía concluyentes. Varios autores sostienen que la circulación siguió siendo intensa hasta avanzado el siglo VI, pero admiten que faltan más investigaciones para refinar el conocimiento y que resulta difícil cuantificar los volúmenes intercambiados ${ }^{825}$. R. B. Hitchner habla de continuidad en los vínculos de la región con África y el Mediterráneo oriental hasta el siglo VII, pero plantea que otros indicadores sugieren que el alcance de la economía del sur galo fue esencialmente regional $^{826}$. Loseby reconoce su incapacidad para establecer magnitudes en el flujo del tráfico a través de Marsella ${ }^{827}$. Las fuentes escritas, por su parte, permiten constatar la existencia de mercaderes (negotiatores) en el periodo. En un pasaje de los Decem Libri Historiae de Gregorio de Tours no encontramos con el enriquecimiento de los comerciantes de Verdún, que se habría originado cuando el obispo Desiderato distribuyó dinero - que a su vez había obtenido como préstamo del rey Teudeberto- a la población hambrienta de la ciudad $^{828}$. De todas maneras, como hemos visto en el capítulo 2, era más común que en casos como este último los obispos recurriesen a recursos propios para atender a su comunidad ${ }^{829}$. Los mercaderes estaban comprometidos más bien en la circulación de bienes demandados por sectores aristocráticos y no tanto en la venta de productos corrientes, que debieron de ser comerciados por los propios productores en ferias locales ${ }^{830}$. Sidonio Apolinar recomendaba en torno a los años en los que se desmoronaba el poder imperial romano el servicio de un mercader que a pesar de tener un modesto pasar, era capaz de conseguir

\footnotetext{
${ }^{824}$ Panella 1993; Loseby 2005, 625-626.

${ }^{825}$ Bonifay y Renaud 2007, 146; Devroey 2003, 154-155; Hitchner 1992.

${ }^{826}$ Hitchner 1992, 130.

${ }^{827}$ Loseby 1992, 173.

${ }^{828}$ Greg. Tur., Hist., 3.34: “apud Viredunensim urbem potiretur, videns habitatoris eius valde pauperes atque distitutus, dolebat super eos; et cum ipse per Theudoricum de rebus suis remansisset extraneus nec haberet de proprio, qualiter eos consolaretur, bonitatem et clementiam circa omnes Theudoberthi regis cernens, misit ad eum legationem, dicens: 'Fama bonitatis tuae in universam terram vulgatur, cum tanta sit tua largitas, ut etiam non petentibus opem praestis. Rogo, si pietas tua habet alequid de pecunia, nobis commodis, qua cives nostros relevare valeamus; cumque hi negutium exercentes responsum in civitate nostra, sicut reliquae habent, praestiterint, pecuniam tuam cum usuris legitimis reddimus'. Tunc ille pietate commotus, septim t ei u milia aureorum pristitit, qua ille accipiens per cives suos erogavit. At illi negutia exercentes divites per hoc effecti sunt et usque hodie magni habentur".

${ }^{829}$ Sid., Ep., 6.12 (474). Véase también V. Caes., 2.9 y V. Gen., 35.

${ }^{830}$ Santos 2009, 8.
} 
dinero para la compra de mercadería gracias a la reputación que se había ganado ${ }^{831}$. No parece ser la realidad de un buhonero, aunque tampoco faltan testimonios sobre este tipo de comerciantes ${ }^{832}$. Otros documentos nos hablan de comerciantes que, en cambio, habían acumulado un patrimonio considerable. Es el caso del sirio que fue forzado a entrar a la Iglesia por el obispo Bertrán de Burdeos, quien buscaba quedarse con sus propiedades $^{833}$. A fines del siglo VI, otro sirio, Eusebio, consiguió hacerse con la sede episcopal parisina a pesar de sus orígenes mercantiles; para llevar a cabo tal empresa seguramente debió de valerse de su capital social y económico ${ }^{834}$.

Parece claro, sin embargo, que se produjo una contracción considerable en el comercio de bienes de lujo. Como señala Wickham apoyándose en Lebecq, la importación de productos mediterráneos (muchos de ellos suntuarios) a través de Marsella fue lo suficientemente importante como para hacer de ella uno de los centros comerciales más exitosos del siglo VI, pero no como para dejar rastros arqueológicos una vez que los bienes eran distribuidos por el territorio franco ${ }^{835}$. Debemos tener en cuenta, además, que Marsella se convirtió prácticamente en el único puerto marítimo meridional de la región, desplazando a otros que habían continuado activos durante el

\footnotetext{
${ }^{831}$ Sid., Ep., 6.8 (c. 472): “Apicum oblator pauperem vitam sola mercandi actione sustentat; non illi est opi ficium quaestui, militia commodo, cultura compendio; (ob) hoc ipsum, quod mercennariis prosecutionibus et locaticia fatigatione cognoscitur, fama quidem sua sed facultas crescit aliena. Sed tamen quoniam illi fides magna est, etsi parva substantia, quotiens cum pecuniis quorumpiam catapli recentis nundinas adit, creditoribus bene credulis sola deponit morum experimenta pro pignore. Inter dictandum mihi ista suggesta sunt, nec ob hoc dubito audita fidenter asserere, quia non parum mihi intumos agunt quibus est ipse satis intumus. Huius igitur teneram frontem, dura rudimenta commendo; et, quia nomen eiusdem lectorum nuper albus accepit, agnoscitis profecturo civi me epistulam, clerico debuisse formatam; quem propediem non iniuria reor mercatorem splendidum fore, si hinc ad vestra obsequia festinans frigoribus fontium civicorum saepe fontem mercatoribus anteferat. Memor nostri esse dignare, domine papa" (Ep., 7.2, 7.7, 7.10 y 9.4).

${ }^{832}$ Greg. Tur., Glor. Mart., 58.

${ }^{833}$ Greg. Tur., Hist., 7.31: "Interea proditur ab episcopo Berthramno Eufron neguciator per inimicitiam, quia invitum aliquando eum totunderat, inhians facultatem eius. Quod ille dispiciens, ad aliam urbem transiens, caesariae crescente, regreditur". Otro mercader tenía dos esclavos que habían huido robándole dinero (7.46: "His diebus Cristoforus negutiatur ad Aurilianensem urbem abiit. Audierat enim, quod ibidem multum vini delatum fuisset. Abiens ergo, conparato vino et lintribus invecto, accepto a sccero pecunia multa, cum duobus pueris Saxonibus viam equitando terebat. Pueri vero diu dominum exosum habentes et plerumque fuga labentes, eo quod crebrius gravissime verberarentur, cum venissent in quadam silva, praecedente domino, puer unus iaculata valide lancea dominum suum transfixit. Quo ruente, alius cum framea capud eius dilaceravit. Et sic ab utroque in frustra decisus, exanimis est relictus. Hii vero accipientes pecuniam, fuga dilapsi sunt").

${ }^{834}$ Greg. Tur., Hist., 10.26: "Ragnimodus quoque Parisiacae urbis episcopus obiit. Cumque germanus eius Faramodus presbiter pro episcopato concurreret, Eusebius quidam negotiator genere Syrus, datis multis muneribus, in locum eius subrogatus est; hisque, accepto episcopato, omnem scola decessoris sui abiciens, Syrus de genere suo eclesiastieae domui ministros statuit. Obiit et Sulpitius Bituricae urbis pontifex, cathedramque eius Eustasius Agustidunenss diaconus est sortitus".

${ }^{835}$ Wickham 1998, 283; Lebecq 1998.
} 
periodo tardo-romano ${ }^{836}$. Por último, pero no menos importante, la endémica violencia debió de convertir la actividad de los intercambios en un asunto sumamente riesgoso, sobre todo para aquellos negotiatores que no contaban con la protección de los poderosos $^{837}$. En suma, coincidimos con McCormick cuando plantea que Pirenne subestimó los cambios ocurridos en la economía de la Galia mediterránea anterior al islam $^{838}$.

La cerámica es otro gran indicador de la declinación de la vida material. Comenzó a tener una facturación más tosca y una circulación más acotada, hecho que encaja perfectamente con la caracterización que hemos hecho de las transformaciones socioeconómicas y que el propio Wickham encuentra difícil de cuadrar con su idea de que la riqueza aristocrática habría sido una peculiaridad de la Galia meridional. En su opinión los cambios en la producción y circulación de este tipo de objetos no evidenciarían formas más complejas de demanda; en todo caso, faltaría hallar para esta región tipos de cerámica que han sido encontrados en otras partes y que se asocian con un intercambio aristocrático ${ }^{839}$. Otros autores, como Bryan Ward-Perkins, sostienen que si la cerámica en general tenía una pobre factura y era hecha localmente, entonces otros productos también debieron de tener la misma falta de sofisticación ${ }^{840}$.

La documentación escrita, por su parte, podría estar reflejando la escasez de mano de obra especializada. En una carta a un tal Celso, Ruricio de Limoges le envía un vidriero que aquel le había pedido, comentando de paso que su trabajo debería ser imitado por su brillantez ${ }^{841}$. En otra de las epístolas de este obispo que han sobrevivido, vuelve a aparecer la referencia a un artesano; en esta ocasión se trata de un pintor, que a pesar de estar trabajando para Ruricio, es enviado por este a una tal Cerania que solicita

\footnotetext{
${ }^{836}$ Loseby 1992, 181-182.

${ }^{837}$ Loseby 2005, 636; Santos 2009, 6-7. Mercaderes fueron saqueados y asesinados en Poitiers por los hijos de Waddo, según el relato de Gregorio de Tours (Hist., 10.21: "Filii autem ipsius Waddonis per Pectavum vagantes, diversa committebant scelera, homicidia furtaque nonnulla. Nam inruentes ante hoc tempus super negutiatores, sub noctis obscuritate eos gladio trucidant abstuleruntque res eorum"). En cuanto a los comerciantes protegidos por poderosos, además del caso de Amancio, cliente de Sidonio, nótese el de Prisco, servidor de Chilperico (Gregorio de Tours, Hist., 6.5 y 6.17). Recuérdese, finalmente, la inseguridad que reinaba en los caminos, apuntada en el capítulo 3.

${ }^{838}$ McCormick 2001, 119. Wickham también critica a Pirenne (2005, 821-823).

${ }^{839}$ McCormick 2001, 60 y Wickham 2005, 746-747 y 758. Bonifay y Renaud (2007) tienen una postura más continuista, en línea con la tesis de Pirenne.

${ }^{840}$ Ward-Perkins 2000b, 348.

${ }^{841}$ Rur., Ep., 1.12 (475/485): "Sed ne exhibeat vobis seu ineptia seu longior sermo fastidium, salve largissimum dico et vitrarium, sicut iussistis, me destinasse significo, cuius opus nitore non fragilitate oportet imitetur, ut dilectio, quae nobis a parentibus relicta, a magistro tradita, vitae communione firmata est, secundis elimetur, adversis nulla penitus turbinum procella frangatur".
} 
sus servicios ${ }^{842}$. Esto podría leerse como dos anécdotas aisladas, pero parecen representativas del orden socioeconómico que estamos reconstruyendo. Renée Doehaerd planteó hace ya varios años que los técnicos cualificados fueron escasos durante toda la temprana Edad Media. Tanto en la época merovingia como en los siglos posteriores se escribía a enormes distancias para obtener sus servicios ${ }^{843}$. Astarita ha señalado que muchos de los servi fugados durante el periodo fueron artesanos que se instalaron como libres en aldeas. Esto habría convertido a la manufactura en un componente más de una economía campesina destinada a la prosecución de la subsistencia. Habría existido una continuidad en el conocimiento de los oficios en un marco al amparo del control aristocrático ${ }^{844}$. Para el sur de la Galia, las prospecciones arqueológicas han detectado la presencia de actividades artesanales en las aldeas situadas en altura en el periodo $c .450-700^{845}$.

En este punto es pertinente retomar la conceptualización que ha hecho recientemente Wickham acerca del papel de las aristocracias en el desarrollo económico temprano medieval. La contracción evidenciada en los documentos (textuales y arqueológicos) tendría como causa la debilidad de los lazos de dependencia. Esto presupone considerar que el crecimiento material en sociedades precapitalistas está dado por la capacidad de las aristocracias de extraer riquezas del campesinado (y en menor medida de los artesanos). No es la originalidad lo que nos lleva a retomar a este autor, sino la ordenada aplicación que hace de esta premisa para el periodo que nos importa. Wickham ha desarrollado con mayor detalle estas ideas en un artículo reciente en el que analiza el papel de las fuerzas productivas en la economía europea de los siglos V-XIII, a modo de comentario sobre críticas hechas a Framing the Early Middle Ages. Arroja luz allí sobre una inconsistencia de particular interés para nosotros, que acertadamente señalara Astarita: en Framing, el desarrollo es atribuido en algunas ocasiones al comercio (se generan "oportunidades" económicas por la apertura de un mercado, las cuales se aprovechan intensificando la explotación) y en otras a la capacidad de las aristocracias para extraer excedente y generar demanda. Devroey demuestra una

\footnotetext{
${ }^{842}$ Rur., Ep., 2.15 (495/500): "Ut pictorem vobis antea non transmitterem, haec res fecit, quia adventu novi iudicis te occupatam esse credidi atque ita deterritam, ut de his rebus cogitare non posses; sed quia deo propitio vos et litteris et relatione vestrorum ex sententia agere ac valere cognovi, salutatione praelata, pictorem, quamlibet hic esset occupatus, cum discipulo destinavi, quia malui meae detrahere necessitati, unde vestrae satisfacerem petitioni".

${ }^{843}$ Doehaerd 1974, 159-161.

${ }^{844}$ Astarita inédito.

${ }^{845}$ Zadora-Rio 2009, 81-83.
} 
confusión similar cuando oscila entre una explicación de la contracción de los mercados - ahora para el caso específico de la Galia- centrada en la ausencia de la capacidad de compra por parte de la aristocracia y otra basada en la interrupción de los canales tradicionales de tráfico ${ }^{846}$. Es importante destacar al respecto que, como indica Astarita, "[e]n sistemas precapitalistas, la circulación no es el objeto de la producción; surge como excedente del consumo y no como objetivo económico. Ese objetivo era la producción de valores de uso que, en ciertas condiciones, se lograba por mediación del mercado" ${ }^{847}$. Esta idea es la que ha sistematizado recientemente Wickham. A partir de las evidencias acerca de la reducción de los intercambios y de la simplificación de la producción cerámica, concluye que

[cuanto] más rica era una elite -tanto si sus miembros eran terratenientes que percibían rentas como si se trataba de una burocracia que percibía impuestos- mayor era la complejidad de los intercambios. Pero a su vez, por supuesto, la riqueza de la elite dependía de la explotación de los productores primarios, esto es, del campesinado. De modo que cuanto mayor era la explotación, mayor era la complejidad económica. Lo primero podía obedecer a que la explotación en sí fuera más intensiva o bien a que fueran más los campesinos explotados, como por ejemplo cuando la aristocracia terrateniente creció a expensas del campesinado independiente (un proceso bien documentado en Francia, Italia y Alemania durante el siglo IX; España durante el siglo X y nuevamente Francia durante el siglo XI) ${ }^{848}$.

Bryan Ward-Perkins plantea la hipótesis de la continuidad en la Galia de la producción de excedente, la cual se habría canalizado en una mejor alimentación del campesinado y en un consumo suntuario aristocrático que no habría dejado huellas arqueológicas, como bienes perecederos y joyas que luego eran fundidas. Sin embargo, lo dicho hasta acá invalida el sustento de esta hipótesis que se enfrenta incluso con la idea de contracción económica general defendida por el propio autor ${ }^{849}$. Sencillamente hay que abandonar la idea de una continuidad en los lazos tradicionales de explotación. Lo que en definitiva se impuso fue una sociedad de base campesina.

\footnotetext{
${ }^{846}$ Devroey 2003, 224 y 154-155 (respectivamente).

${ }^{847}$ Astarita 2007, 263.

${ }^{848}$ Wickham 2012, 13-14. Véase también Wickham 1988.

${ }^{849}$ Ward-Perkins 2000b, 380.
} 


\section{CONSIDERACIONES FINALES}

Es preciso concluir esta tesis doctoral con una síntesis de lo expuesto hasta aquí y con una definición de lo que entendemos por "sociedad de base campesina". En cuanto a lo primero, no se trata meramente de resumir los distintos capítulos, sino de priorizar ahora una exposición de la lógica interna del problema estudiado por sobre la complejidad y matices del proceso histórico.

Comencemos por el funcionamiento del aparato fiscal. Hemos planteado que para el año 400 las exigencias públicas eran muy elevadas; probablemente ascendieran a un cuarto del total del producto imperial. No obstante, el sistema no se hallaba en crisis ni estaba afectando de modo negativo en lo económico a las regiones que tributaban. Un punto clave para su éxito era que no encontraba grandes resistencias por parte de las elites locales. Quienes ocupaban los gobiernos municipales o los que estaban vinculados a aquellos por lazos de amicitia lograban beneficiarse de la instrumentación del cobro o al menos aminorar o evadir las responsabilidades como contribuyentes. La corrupción estaba a la orden del día; el sistema era opresivo y su puesta en funcionamiento estaba plagada de injusticias. No faltamos a la verdad si planteamos que en general estas últimas perjudicaban a los peldaños más bajos de la escala social, aunque también parte de las elites corrieron esta suerte. Todo dependía de cuán alejado se estaba de los resortes del poder. En cualquier caso, la mayor parte de los gastos del Estado era financiada con el sudor de los campesinos.

Este funcionamiento más o menos estable del sistema comenzó a verse en peligro luego de 406. La necesidad de destinar más fondos a la defensa militar obligó al 
Estado a incrementar la presión fiscal, tanto mayor cuanto la base contribuyente comenzó a contraerse como producto de la pérdida de territorios o la devastación de algunas regiones. Si bien no puede sostenerse una lectura catastrofista sobre los efectos de las incursiones bárbaras en el periodo 406-416, la región de la Galia meridional se vio perturbada por la presencia prolongada de varias decenas de miles de germanos dedicados a una economía del saqueo. Detrás de las exageraciones retóricas de las fuentes es posible ver las consecuencias materiales de la guerra. Hubo pequeñas coyunturas favorables en los años siguientes, pero en el largo plazo la presencia germánica en el territorio imperial se dejó sentir de manera cada vez más fuerte. Por otro lado, las primeras incursiones empezaron a crear inestabilidad en la estructura social rural, pues sabemos que los ejércitos invasores fueron un polo de atracción para los dependientes. De todos modos, este fenómeno debió de ser marginal en la región de nuestro estudio durante esos años.

El periodo transcurrido entre el asentamiento visigodo en Aquitania y la pérdida de África no fue el de una paz que permitiera una tranquila reconstrucción. Los visigodos aprovecharon cada momento propicio para quebrar el acuerdo con el imperio y realizar incursiones de saqueo; Aecio debió hacer frente a bagaudas, burgundios y francos entre 435 y 439; el imperio continuó perdiendo territorios de la Galia (buena parte del noroeste y del noreste y Aquitania) y se extendieron las huidas hacia los enemigos (ahora también a las bagaudas, como testimonia Salviano). La pérdida de las provincias de Bizacena y Proconsular fue el golpe de gracia a las finanzas imperiales. El hecho se evidencia en las leyes promulgadas por el emperador Valentiniano III en los años inmediatos y en la premura de la corte por emprender la reconquista. El fracaso en esta tarea fue debilitando aún más al imperio, que continuó perdiendo dominios a manos de los bárbaros. Incluso había regiones en las que aparecían formaciones políticas autónomas, como en el norte de la Galia. El gobierno central ya no cumplía con su función protectora.

De todos modos, para la región que nos ocupa fueron con seguridad muchos más duros los efectos indirectos de las guerras en el periodo circunscrito entre las invasiones de 406 y el fin del orden imperial. Probablemente al promediar la década de 430 Roma solo contara con un tercio de los territorios que administraba al comenzar el siglo. Esto significó una mayor presión fiscal sobre los territorios que todavía se hallaban bajo su control. 
El aumento global de la carga fiscal producido desde comienzos del siglo V se tradujo en una presión muy dura para el campesinado. Podemos constatar que esto se dio con particular crudeza en la Galia meridional gracias al De gubernatione Dei de Salviano de Marsella. También sabemos a partir de este texto que las aristocracias tradicionales aún controlaban los asuntos municipales y que incluso lograron someter a dependencia a parte de ese campesinado a través del patrocinium. La propiedad de la tierra había ido acaparándose en cada vez menos manos durante el periodo tardoromano en occidente; el proceso está documentado textual y arqueológicamente para la Galia meridional. En la primera mitad del siglo V la presión fiscal contribuyó con toda probabilidad a una mayor concentración y al aumento del número de dependientes. El patrocinium que protegía contra los recaudadores de impuestos se convirtió en un mecanismo de pérdida de la propiedad y de la independencia para muchos campesinos. Buena parte de la masa rural -fueran esclavos o coloni- se hallaba entonces sometida a vínculos de dependencia privados y a explotación pública.

Los conflictos militares comenzaron a tener un impacto más directo en la Galia meridional desde el último tercio del siglo V. Visigodos, burgundios y francos se lanzaron en distintos momentos a una política decididamente expansiva, lo que tuvo como consecuencia que la región se convirtiera recurrentemente en teatro de operaciones bélicas. El fin de la empresa de conquista de Clodoveo no supuso una solución de continuidad a esta dinámica, pues los distintos herederos de la familia merovingia siguieron luchando por acrecentar sus dominios. La propia lógica del poder empujaba a los soberanos a obtener tierras y riqueza con las que recompensar el apoyo de las aristocracias.

Pero además las fuentes dan cuenta de la ubicuidad de otro tipo de violencia, menor, cotidiana, impulsada por el accionar de bandas armadas. Cuando las campañas de los reyes sufrían alguna interrupción aquellos que integraban los ejércitos continuaban dedicándose al saqueo y al pillaje, aunque a otra escala; los soldados se transformaban en salteadores y bandidos.

Toda esta violencia tuvo graves consecuencias materiales en la región estudiada. No solo era dañino el ataque puntual, el asedio de una región, sino también el mero paso de un ejército. Lo vimos con el ejemplo del viaje de la comitiva de Rigunta. La constancia en el robo de animales, en el incendio de edificios rurales, en el saqueo de las 
cosechas dificultaba enormemente las posibilidades de recuperación de los territorios afectados.

El aparato fiscal entró en crisis en la segunda mitad del siglo V. Aunque las fuentes evidencian la presencia de cobro de gravámenes en las últimas décadas de dominio romano y durante el siglo VI, lo cierto es que no hubo una continuidad del sistema. Hemos defendido la hipótesis de que los reinos merovingios tuvieron serias dificultades para mantenerlo, a pesar de que lo intentaron. Se constata en todo caso la existencia de exacciones irregulares en el tiempo y en el espacio. Algunos reyes encontraron dificultades para mantener las prácticas heredadas, mientras que otros lograron reimponer el cobro temporalmente. Pero allí donde sobrevivieron, los impuestos no parecen haber sido gravosos.

Detrás de este proceso se hallaba menos la indiferencia del poder público que la resistencia de los contribuyentes. En última instancia esto se conecta con la lenta caída de las estructuras estatales romanas como producto de las invasiones germánicas. El prolongado enfrentamiento con los bárbaros avivó el conflicto social interno. Un Estado incapaz de ofrecer seguridad exigía impuestos cada vez más elevados. Esto fue minando el consenso de las aristocracias locales, que encontraron dificultades para beneficiarse de la puesta en funcionamiento del sistema y que además se hallaban muchas veces a merced de los invasores (o ante el peligro latente de una incursión). Sin este apoyo a nivel celular difícilmente podía mantenerse con vida el sistema. Por otro lado, las aristocracias fueron militarizándose, lo que les permitió establecer un vínculo más igualitario con las nuevas autoridades bárbaras. El impuesto pasaría a ser percibido por ellas como una marca de falta de libertad.

Pero además la inestabilidad del orden público y las guerras continuas en la Galia meridional redundaron en la multiplicación de núcleos campesinos autónomos, nutridos no solo de quienes huían del fisco, sino también de servi y coloni que escapaban de sus señores. En nuestra opinión, las fugas que encontramos evidenciadas desde la segunda mitad del siglo $\mathrm{V}$ eran la consecuencia de problemas crecientes para sostener los lazos de dependencia. El fenómeno se incrementó con la caída del Estado romano, porque los reinos bárbaros fueron incapaces de montar un aparato represivo eficaz. Los señores ya no tenían a su disposición medios públicos y privados para prevenir y recuperar a aquellos de sus subordinados que se fugaban. Asimismo, la existencia de entidades políticas en permanente conflicto facilitaba la búsqueda de 
refugio fronteras afuera. En este contexto, incluso la amenaza de huida o la fuga misma podían utilizarse como expediente para mejorar las condiciones laborales. Pudieron haber continuado existiendo esclavos y colonos que tenían un vínculo más laxo con sus señores; ello podría explicar las bajas rentas pagadas en el midi que encontramos en fuentes del siglo VIII. Por otro lado, la toma de prisioneros para exigir un rescate o para ser vendidos como esclavos se vio incrementada por el pulular constante de bandas armadas. El constante flujo y reflujo de servi también dificultaba la estabilidad de los lazos de dominación. Por último, la proliferación de dichas bandas en el periodo postromano redundó en un beneficio para los campesinos que se integraron a ellas. Estos sectores podían ahora proteger sus intereses mediante las armas; estaban mejor posicionados para negociar su vinculación (y la de sus allegados) con los aristócratas.

Hemos visto que es difícil demostrar la conformación de estos núcleos independientes con documentación escrita disponible; pero también que las transformaciones ocurridas en la ocupación de la tierra -visibles en el registro arqueológico- encuentran una explicación plausible en la emergencia de dicho proceso. Para el siglo VI se constata un empobrecimiento material en la Galia meridional. Se percibe arqueológicamente el desarrollo de asentamientos rurales de un nuevo tipo (en los antiguos oppida, en las ruinas de las villae, en las grutas). No se han hallado allí objetos que denoten una desigualdad social sustancial o más bien se perciben rastros que indicarían una diferenciación tenue, lo que evidenciaría la presencia de una aristocracia laica y eclesiástica destacada más por su status que por su riqueza. La innovación en la forma de ostentación de ese status superior fue la adaptación a una realidad de pobreza material relativa (el ornamento pasó a destacarse, la construcción en piedra de las residencias privadas desapareció). No se trató de un cambio identitario, sino de la imposibilidad de extraer excedentes explotando a otros. Los sectores aristocráticos se vieron obligados a comenzar a construir liderazgo a partir de lazos horizontales con el campesinado: es lo que vemos en el accionar de los santos y de los líderes de las comitivas armadas. Pero como sabemos, la elite se tornó un grupo fluido durante el periodo, lo que siembra dudas sobre el éxito de esa empresa. Recordemos que no existía la figura retórica del homo novus: no había advenedizos, por ende no había aristocracia tradicional. Si en el siglo $\mathrm{V}$ veíamos a campesinos obligados a someterse a un tipo de patronazgo que encubría una relación de explotación, ahora vemos a miembros de la elite que deben apelar a la reciprocidad para reconstruir su poder social. 
Por otro lado, el proceso descrito encuentra su correlato en la caracterización general de la economía de los siglos V y VI. Hemos retomado en la tesis los planteos que sostienen que el crecimiento material en sociedades precapitalistas se produce cuando determinados grupos logran diferenciarse y extraer riquezas del campesinado (y en menor medida de los artesanos). La simplificación de la vida material remite, inversamente, a la incapacidad por parte de las aristocracias y de los Estados de obtener un excedente estable. Las fuentes escritas y los restos arqueológicos dejan traslucir la depresión agrícola. La cerámica de volvió más rudimentaria en su elaboración y más localizada en su circulación, atributos que podrían generalizarse a la manufactura en general. Los técnicos cualificados fueron escasos en la temprana Edad Media y la Galia del siglo VI no parece haber sido la excepción. Muchos de los servi fugados durante el periodo fueron artesanos que se instalaron como libres en aldeas, convirtiendo la manufactura en un componente más de una economía campesina destinada a la prosecución de la subsistencia. Finalmente, los intercambios se hicieron menos frecuentes y más locales.

En síntesis, si en la primera mitad del siglo V hubo continuidad en las relaciones de dependencia e incluso se gestaron nuevas a partir de los vínculos de patrocinia, en la segunda fueron incrementándose los núcleos campesinos independientes que hegemonizarán el paisaje rural en pleno siglo VI. Detrás del cambio están los complejos efectos de una desestabilización provocada por acontecimientos político-militares también complejos. Existió un periodo de solapamiento entre los procesos descritos que es necesario destacar, aunque sea difícil establecer su cronología y caracterizar su naturaleza. Pero en cualquier caso, la primera de las dinámicas descritas -la caída en dependencia- fue progresivamente marginada por la segunda -la obtención de la libertad-; no obstante, ello no supuso la desaparición de las relaciones de explotación en el área rural. Esclavos y colonos continuaron existiendo.

Surgió entonces una sociedad de base campesina. Hemos caracterizado someramente lo que entendemos por este concepto en los inicios de esta tesis, pero es oportuno ahora volver sobre el mismo con cierto detalle. Ello nos obliga a regresar también sobre la noción de "modo de producción campesino", cuya definición resulta controvertida. En el capítulo 1 expusimos la interpretación dada por Wickham, que se inspiraba en los trabajos de Alexander V. Chayanov y algunos antropólogos, entre ellos 
Marshall Sahlins. Para el autor ruso, los campesinos son productores agrícolas que organizan sus actividades económicas con el propósito de satisfacer las necesidades de subsistencia de sus familias. Su motivación es diferente de la de un empresario, que como resultado de la inversión de su capital recibe la diferencia entre el ingreso bruto y los gastos generales de producción, pero se asemejaría, en todo caso, a la de un obrero, que en un sistema a destajo determina por sí mismo el tiempo y la intensidad de su trabajo $^{850}$. Para Chayanov los campesinos tienen una particular racionalidad económica, basada en el balance entre la necesidad familiar de satisfacción del consumo y el desinterés por las actividades laborales. Lo que define el producto de la unidad campesina es el grado de auto-explotación de la fuerza de trabajo familiar, que se establece a partir de las necesidades de consumo de dicha unidad. Lograda la satisfacción de las demandas del consumo del hogar -la meta de producción del campesino- se produce un equilibrio entre trabajo y consumo. La producción se detiene en ese punto porque cualquier otro aumento en el desgaste de fuerza laboral resulta subjetivamente desventajoso $^{851}$. Por otra parte, el nivel de dicho equilibrio está determinado por el tamaño y las características de la familia, es decir, por cuáles de sus miembros son activos y cuáles no, por la relación entre consumidores y productores. Marshall Sahlins llamó "regla de Chayanov" a la situación generalizada por la cual en una comunidad conformada por grupos domésticos de productores cuanto mayor es la capacidad relativa de trabajo de las unidades, menos se esfuerzan sus miembros ${ }^{852}$. Finalmente, la eventual obligación del pago de rentas o de prestaciones de servicios hacia otros no cambia en nada, para el autor ruso, el comportamiento económico de los campesinos $^{853}$.

No es pertinente que nos explayemos ahora sobre las distintas críticas que se han hecho a la teoría chayanoviana del funcionamiento de la unidad productiva campesina y al concepto de "economía campesina", excepto las planteadas por Pierre Vilar en 1980. Este historiador desconfiaba de la idea de una economía formada enteramente por unidades productivas familiares, capaces de reducir o aumentar constantemente la producción según las variables necesidades de consumo, sin déficits

\footnotetext{
${ }^{850}$ Chayanov [1925], 33-34. Véase también Heynig 1982, 128-129 y Cortés y Cuéllar 1986, 84-85.

${ }^{851}$ Chayanov [1924], 54-55 y 80-85. Consúltese también Heynig 1982, 129 y Tannenbaum 1984, 27. Cf. Vilar 1980, 25, que señala que la pretendida "auto-explotación" no es otra cosa que "explotación del núcleo familiar".

${ }^{852}$ Sahlins 1983, 103; Chayanov [1924], 57.

${ }^{853}$ Chayanov [1924], 66-67.
} 
fuertes ni acumulación de excedentes. Las objeciones son atendibles, pero se vinculan a los problemas que Vilar veía en la aplicación del concepto al análisis de la transición al capitalismo desde una sociedad en la que el campesinado ya se encontraba sometido a relaciones de explotación:

[No existe] un campesinado, un problema campesino. Lo que existe en una sociedad rural son campesinos socialmente diferenciados, los cuales, en la transición del feudalismo al capitalismo, ya no tienen la unidad original de su clase -ésta derivaba de la sumisión y de los derechos que todo campesino debía al señor-. La economía mercantil, cuando penetra en la economía campesina en sus distintos niveles, determina en el seno del campesinado una jerarquía significativa, subrayada periódicamente por las crisis alimenticias ${ }^{854}$.

Por lo tanto, la noción de "sociedad campesina" podría adaptarse al estudio de otras realidades, no solo a la de las sociedades llamadas "primitivas" sino incluso a la del periodo temprano medieval, es decir, sociedades en donde, para Vilar, "todas las clases sociales y los mismos poderes políticos tenían como denominador común el ambiente rural" $" 855$. Sahlins concluyó a partir de sus estudios antropológicos que las relaciones políticas y de parentesco entre las unidades domésticas promueven la producción más allá de lo corriente en ciertas casas que se encuentran en condiciones de hacerlo, mientras que en otras se produce la situación inversa. Sin embargo, en las sociedades “primitivas" la diferenciación no conduce en su opinión a una acumulación por parte de las unidades productoras de excedente porque el trabajo más intensivo de unos se neutraliza con el menos intensivo de otros ${ }^{856}$. La cuestión de la posibilidad de la diferenciación interna campesina es importante y atañe a una mejor definición del concepto con el que estamos tratando, pero no ha sido nuestro centro de interés en esta tesis $^{857}$. Lo que hemos querido establecer aquí es que muchos núcleos poblacionales de la Galia meridional no evidenciaban grandes diferencias de riqueza. El registro arqueológico permite ver en algunas aldeas la presencia de un sector diferenciado levemente de sus vecinos, una elite que bien podría haberse originado internamente. Hemos planteado que la inserción de campesinos en las bandas armadas del periodo

\footnotetext{
${ }^{854}$ Vilar 1980, 286.

${ }^{855}$ Vilar 1980, 295.

${ }^{856}$ Sahlins 1983, cap. 3 .

${ }^{857}$ Henning (2008) ha planteado la existencia de excedente campesino apropiado por los mismos productores en algunas regiones durante la temprana Edad Media.
} 
mejoró probablemente su posición de cara a la aristocracia para la que guerreaba; podría pensarse asimismo la hipótesis de que esto fue el basamento para la diferenciación sobre sus vecinos. En cualquier caso, estaríamos cerca de esa "unidad original de clase" de la que hablaba Vilar.

Tendiendo presentes estas consideraciones, creemos posible definir mínimamente el "modo de producción campesino", entendiendo el mismo no como un "tipo ideal" -como pretende Wickham-, sino como una abstracción conceptual en una realidad histórica de la forma concreta en que una determinada sociedad organiza la producción. A nuestro juicio el modo de producción campesino se basa en el control del proceso productivo por parte de los hogares campesinos, cuyo objetivo es la reproducción de la casa y el mantenimiento de los vínculos con el exterior, que tienden a ser igualitarios (tanto los que se establecen con las otras células campesinas como con las aristocracias). Por ende, esta forma de producción tiende a excluir la explotación. Pero esto no quiere decir que no pueda coexistir con otros modos. Hemos argumentado a lo largo de esta investigación que la extracción de excedente por parte del Estado y de las aristocracias entró en crisis en la segunda mitad del siglo $\mathrm{V}$, pero también que resulta evidente que no desaparecieron. Agreguemos ahora que cada una de estas formas de explotación de los campesinos constituye un modo de producción particular, puesto que los mecanismos por los cuales se extrae el excedente inciden directamente en la estructura de la sociedad (de otra manera entenderíamos mal el conflicto de intereses entre las aristocracias y el Estado, dos clases dominantes distintas). Esto implica considerar los llamados "elementos superestructurales" como parte constitutiva de los modos precapitalistas ${ }^{858}$.

Llegados a este punto, resulta operativo valernos del concepto de "formación económico-social", entendido como la articulación en una sociedad dada de distintos modos de producción, donde uno de ellos es dominante ${ }^{859}$. Esto no supone, como ha planteado Carlos García Mac Gaw, desplazarnos de un nivel abstracto (el modo de producción) a uno concreto (la formación económico-social), sino movernos dentro de un mismo nivel de abstracción de la realidad ${ }^{860}$. Entonces, por "sociedad de base campesina" debe entenderse la formación económico-social en la que el modo

\footnotetext{
${ }^{858}$ García Mac Gaw 2003a.

${ }^{859}$ Una discusión más amplia sobre el concepto de "formación económico-social" en Luporini y otros 1986.

${ }^{860}$ García Mac Gaw 2003a, 221.
} 
campesino se impuso sobre las formas públicas y privadas en que continuó organizándose - aunque de modo regresivo- la extracción de excedente ${ }^{861}$. El objetivo de esta tesis ha sido estudiar su génesis. Hacia mediados del siglo VI los reyes ya no eran capaces de imponer exacciones públicas sobre sus súbditos y las aristocracias encontraban obstáculos para explotar regularmente al campesinado. No se impuso, sin embargo, una sociedad igualitaria. Las elites laicas y eclesiásticas lograron mantener con éxito variable- el dominio directo sobre una parte de la población; continuaron existiendo servi y coloni y la extracción del excedente que producían alimentó aún los circuitos comerciales. Pero en términos generales los núcleos poblacionales independientes se hicieron mayoritarios e impusieron su lógica al conjunto de la sociedad. Esto se vio reflejado en la incapacidad del poder público para mantener el orden social pretendido, en la búsqueda de nuevas formas de ostentación del status y en la necesidad por parte de reyes y de aristócratas de ir a la guerra para obtener riquezas y apoyo por parte de sectores más amplios de la sociedad.

\footnotetext{
${ }^{861}$ Huelga aclarar que no consideramos que todas las formas de apropiación privada del excedente constituyan un mismo modo de producción. Estamos pensando aquí en la que predominó en el periodo analizado, la extracción de renta a coloni y servi.
} 


\section{APÉNDICE CARTOGRÁFICO}




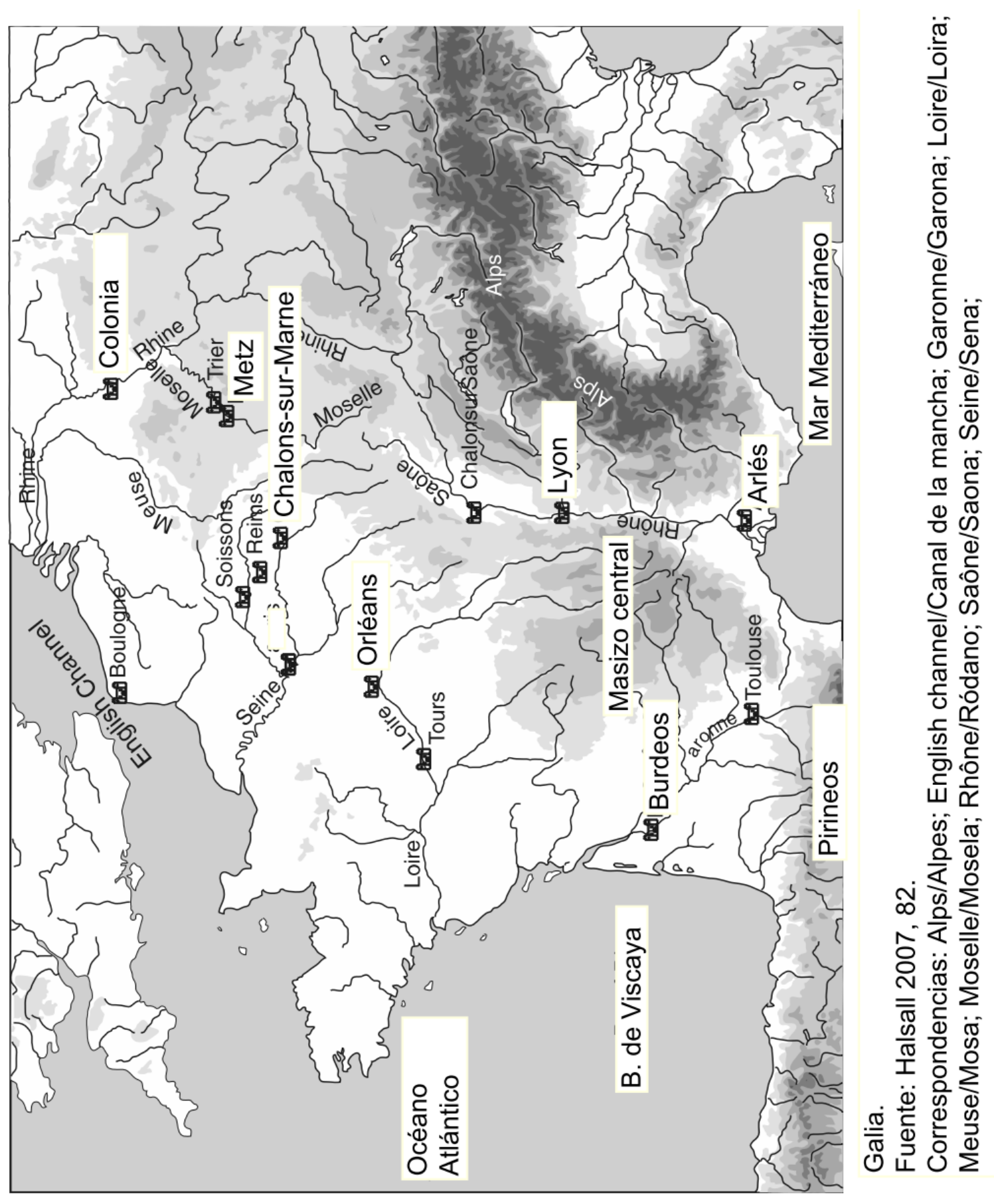




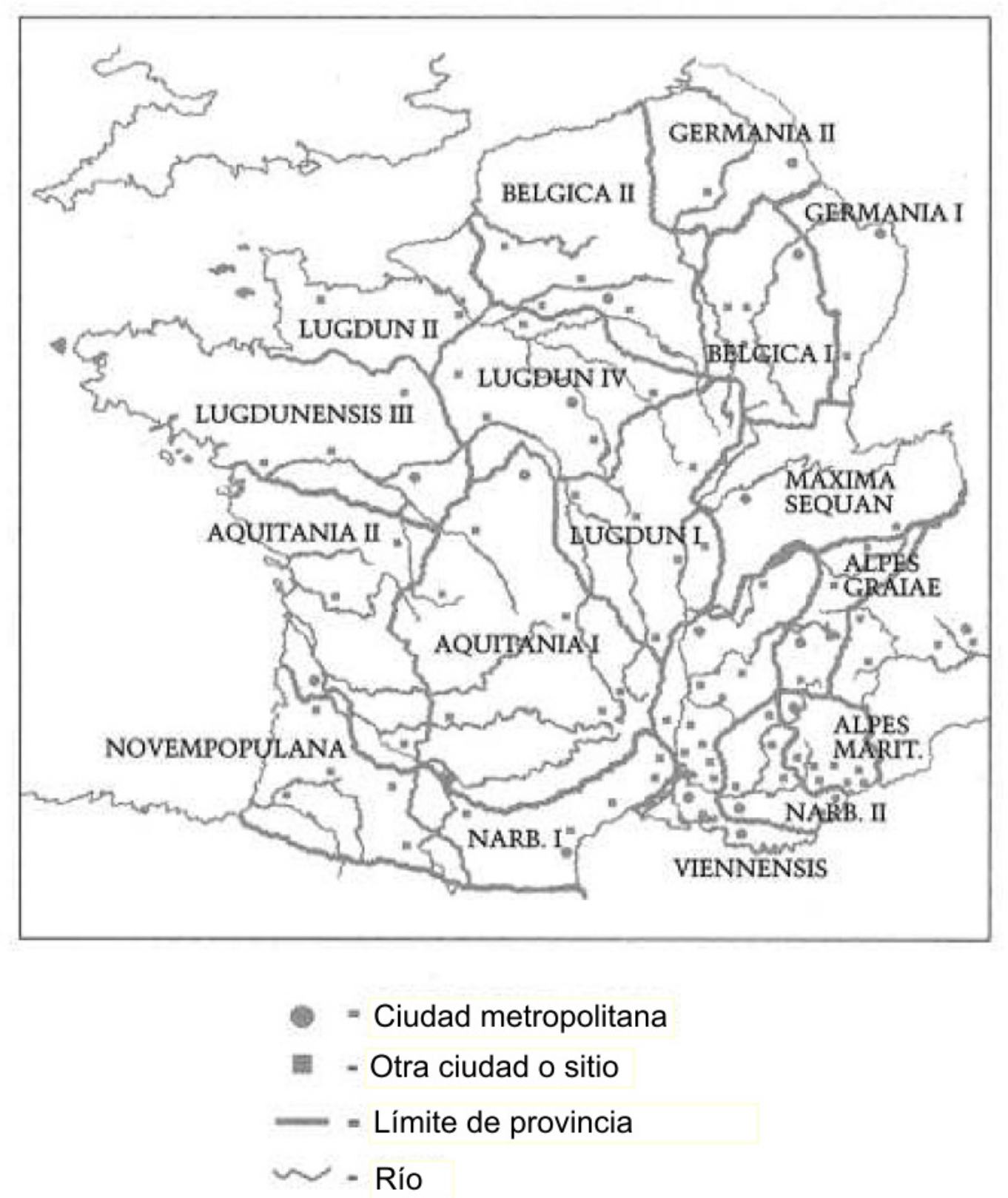

Provincias de la Galia en el siglo V.

Fuente: Mathisen 1993, 3. 

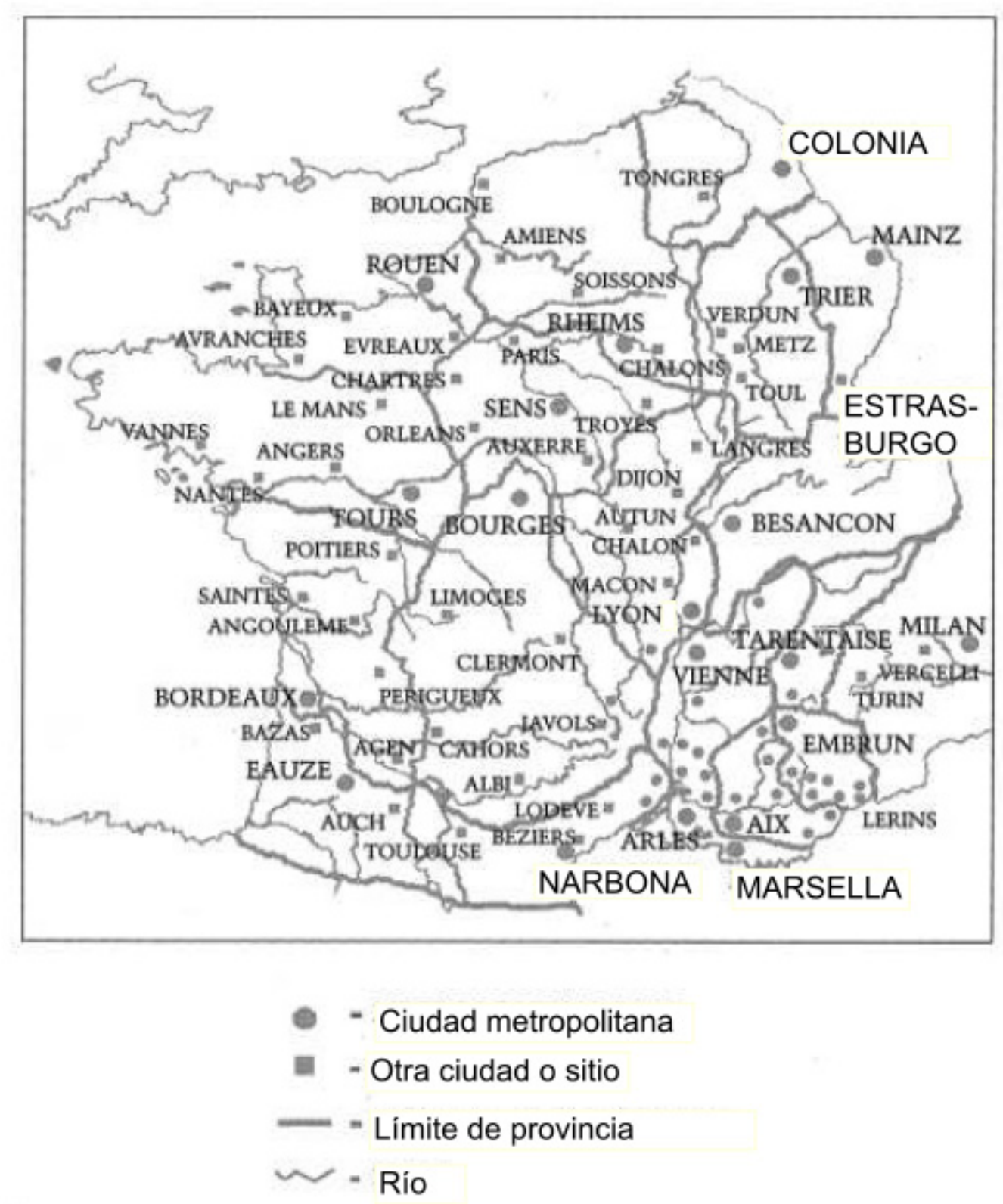

Ciudades de la Galia tardo-antigua.

Fuente: Mathisen 1993, 4. 


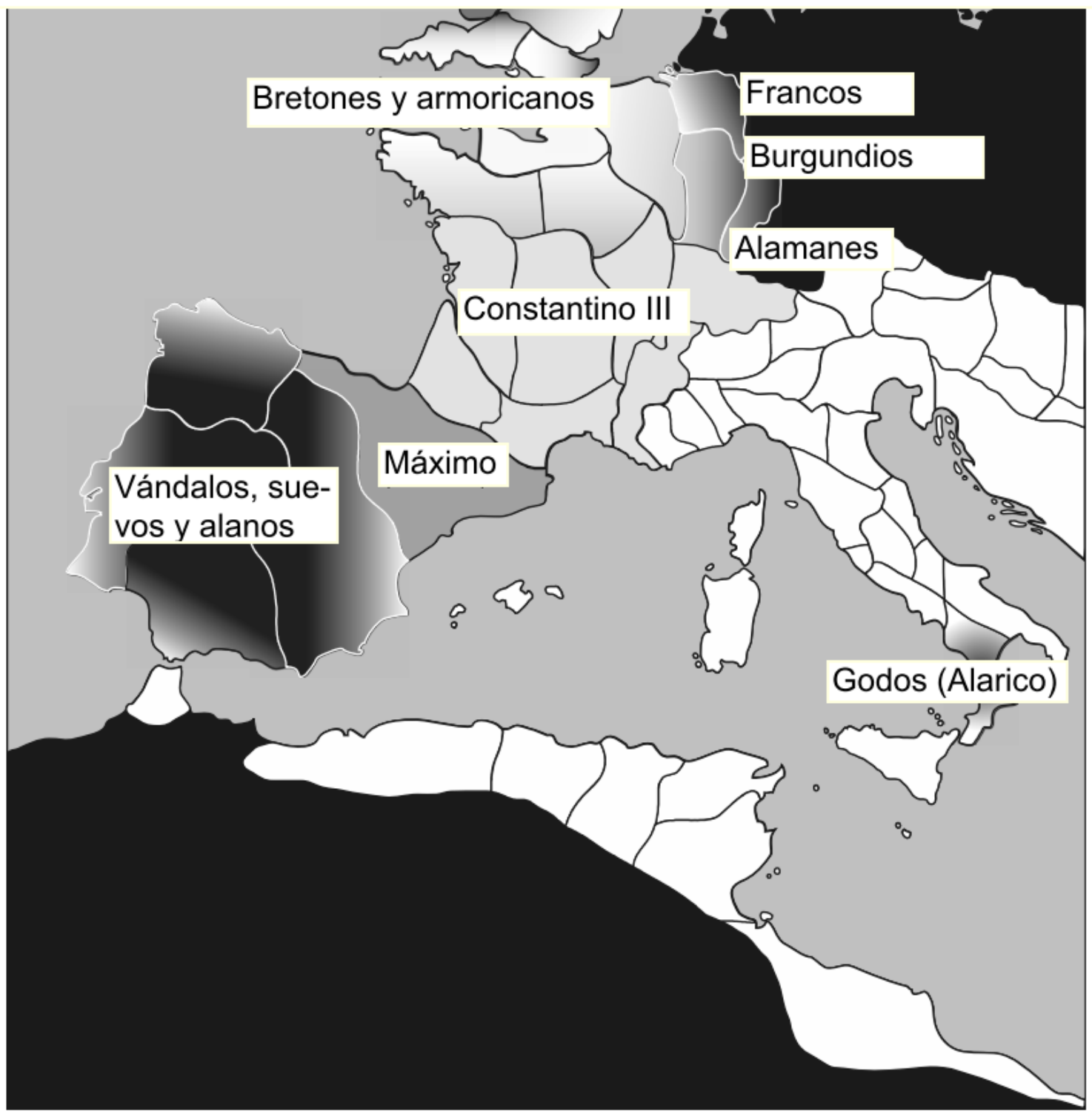

El imperio romano de occidente hacia 410.

Fuente: Halsall 2007, 221. 


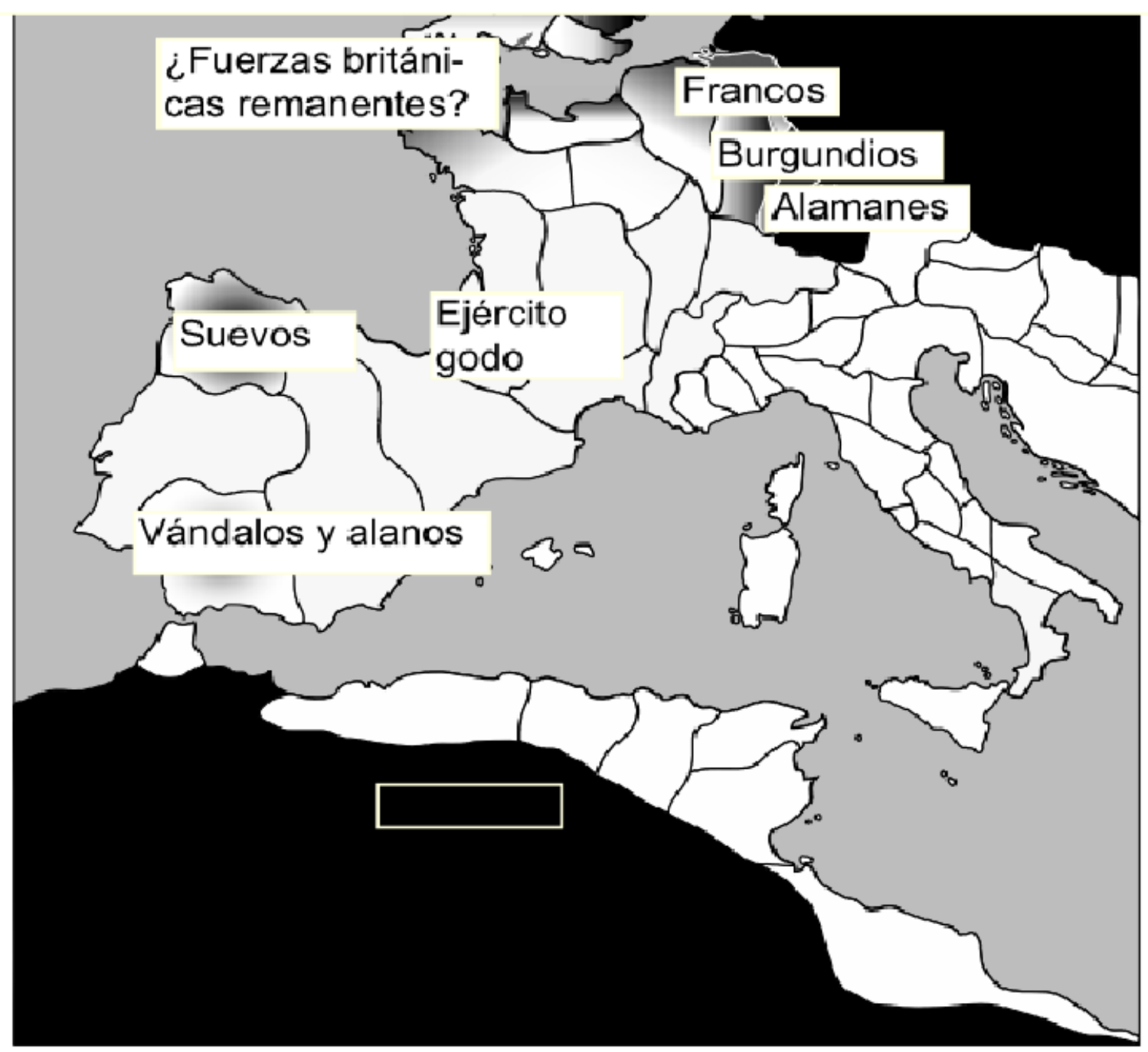

El imperio romano de occidente en 421 (muerte de Flavio Constancio). Fuente: Halsall 2007, 235. 


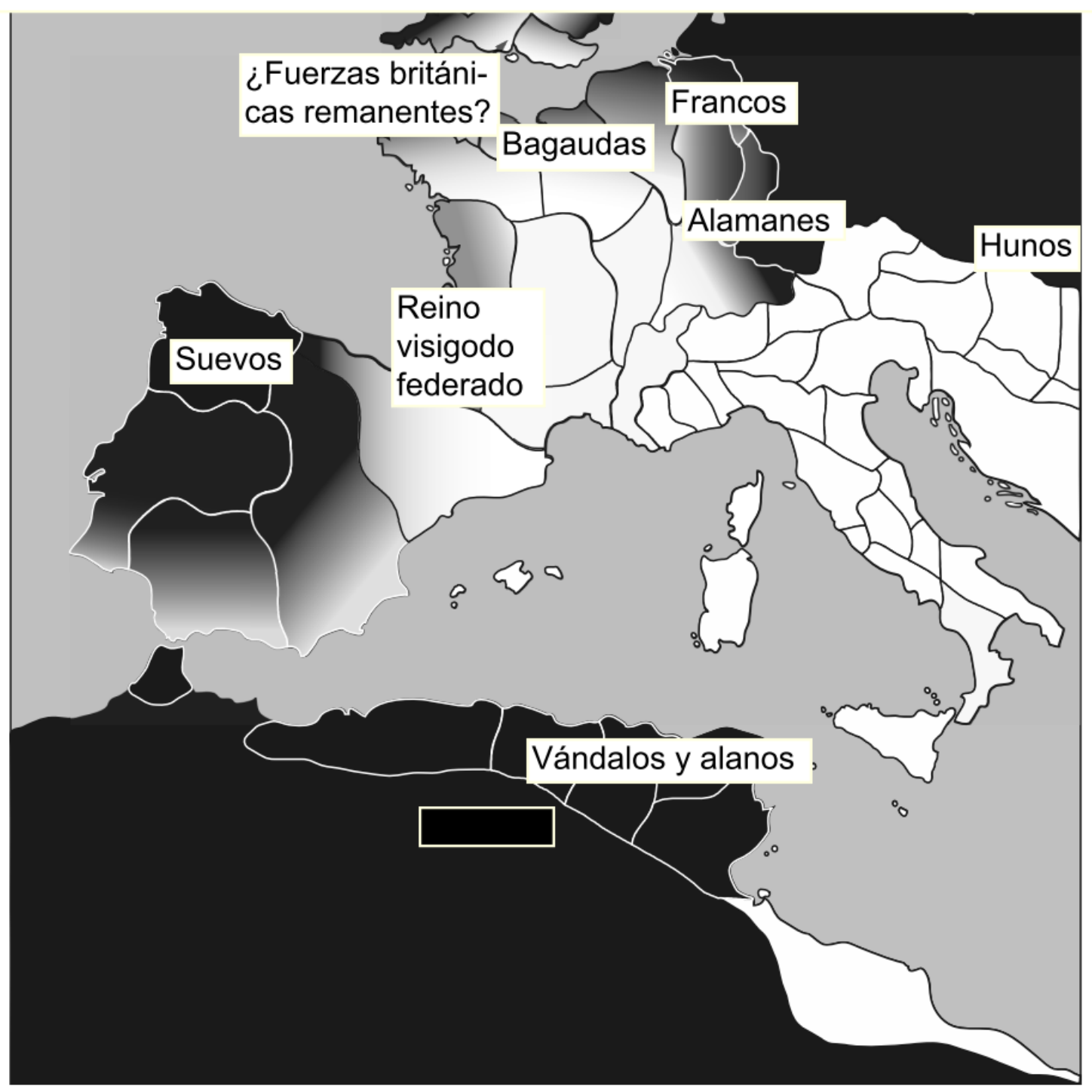

El imperio romano de occidente luego de 439.

Fuente: Halsall 2007, 246. 


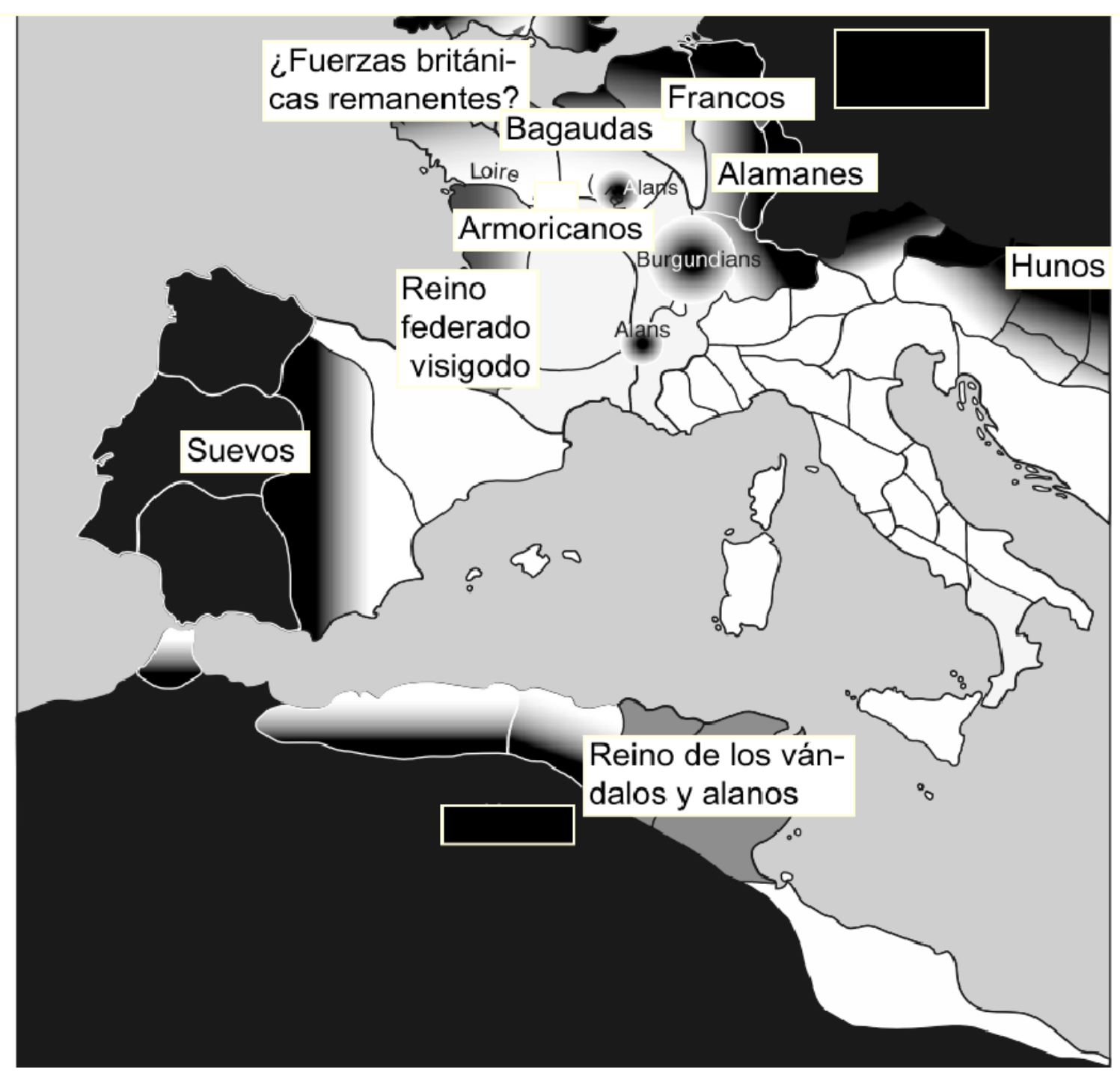

El imperio romano de occidente hacia 455.

Fuente: Halsall 2007, 256.

Correspondencias: Alans/Alanos; Burgundians/Burgundios; Loire/Loira. 


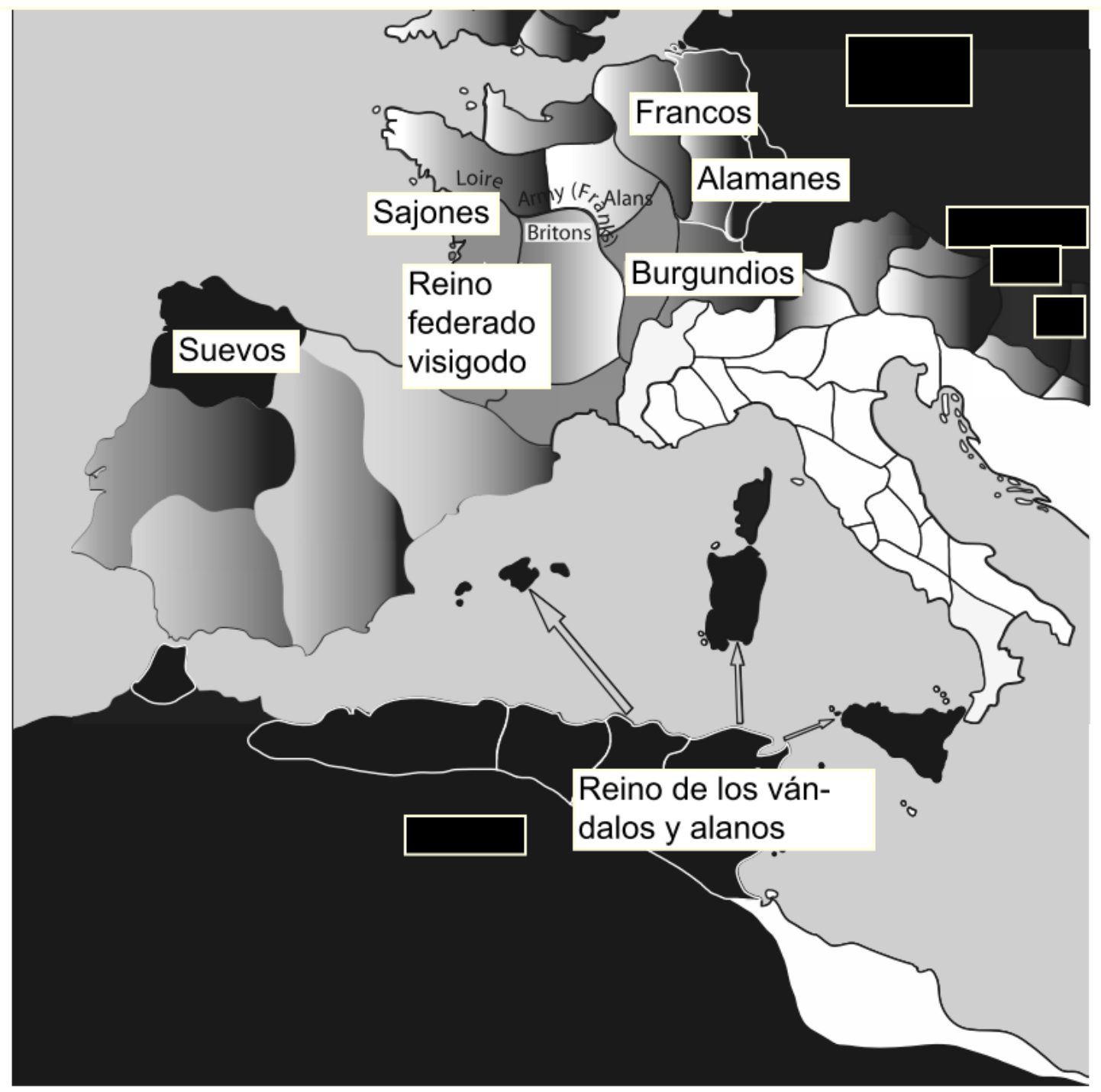

El imperio romano de occidente c. 470.

Fuente: Halsall 2007, 275.

Correspondencias: Alans/Alanos; Army (Franks)/Ejército de francos;

Britons/Bretones; Loire/Loira. 


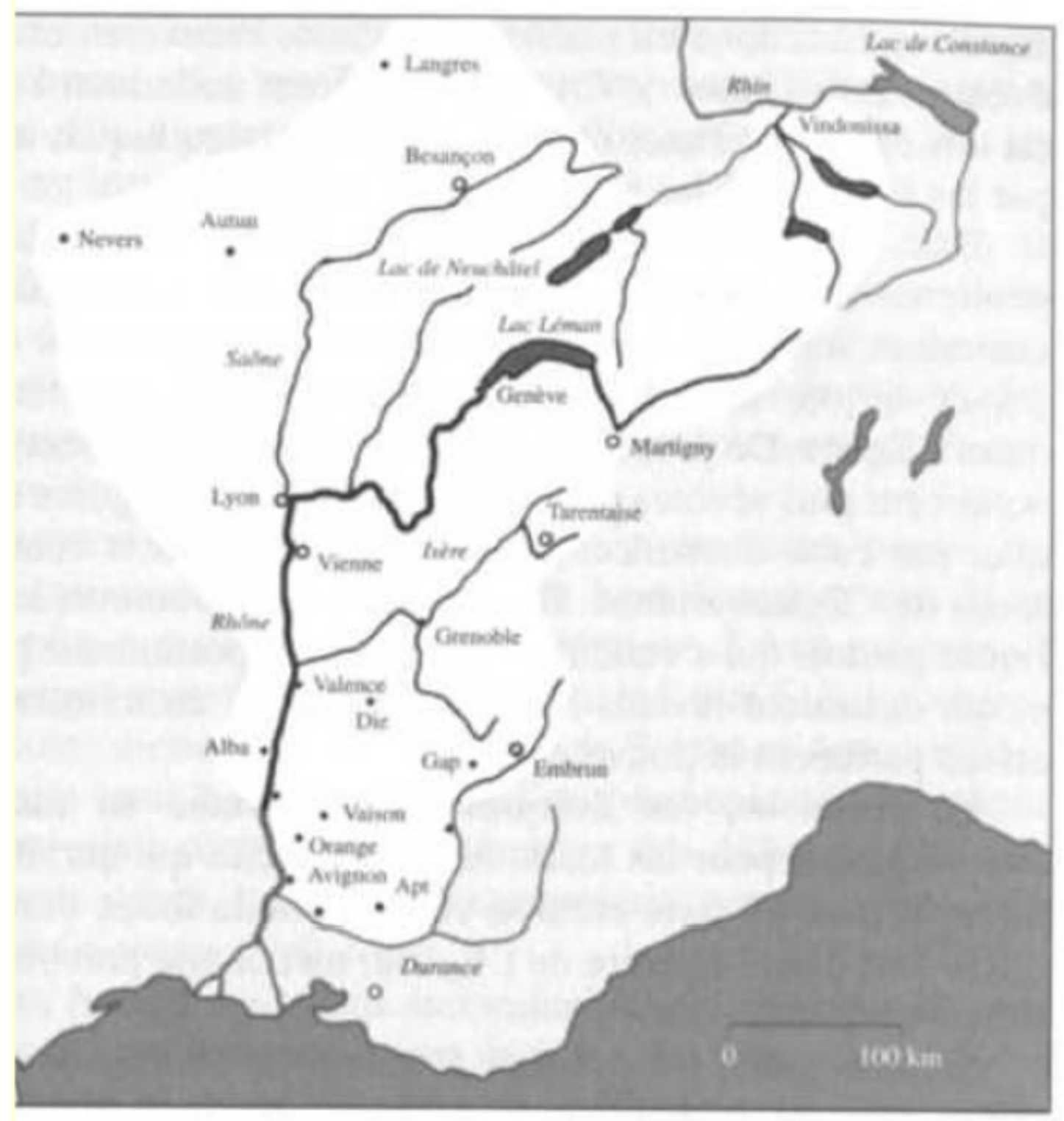

El reino burgundio en 517.

Fuente: Favrod 2002, 109.

Correspondencias: Lac/Lago; Rhin/Rin; Rhône/Ródano. 


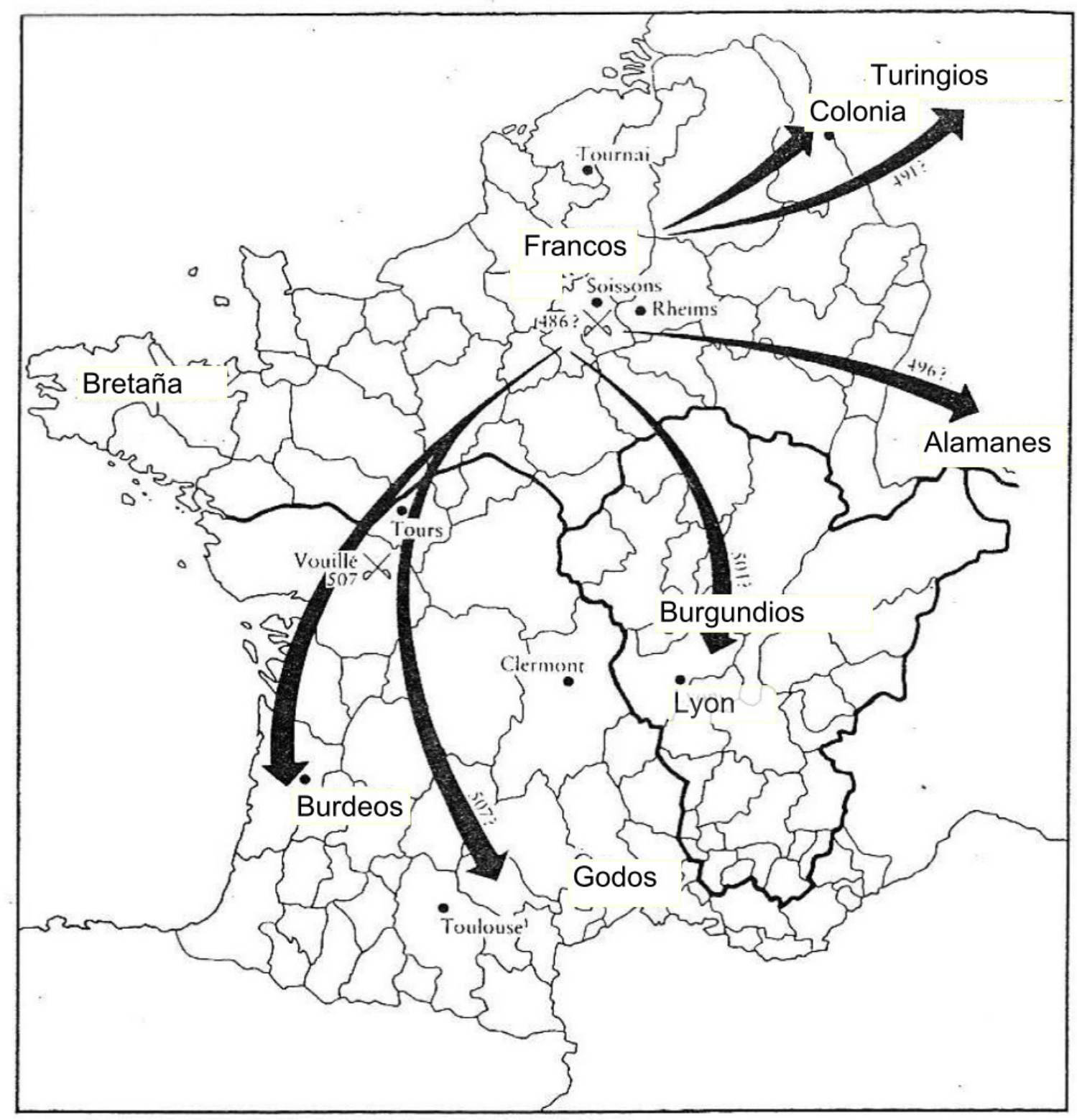

Campañas de Clodoveo. Las fronteras son las de c. 506 y las divisiones internas se corresponden con los límites de las civitates.

Fuente: James 1988, 80. 


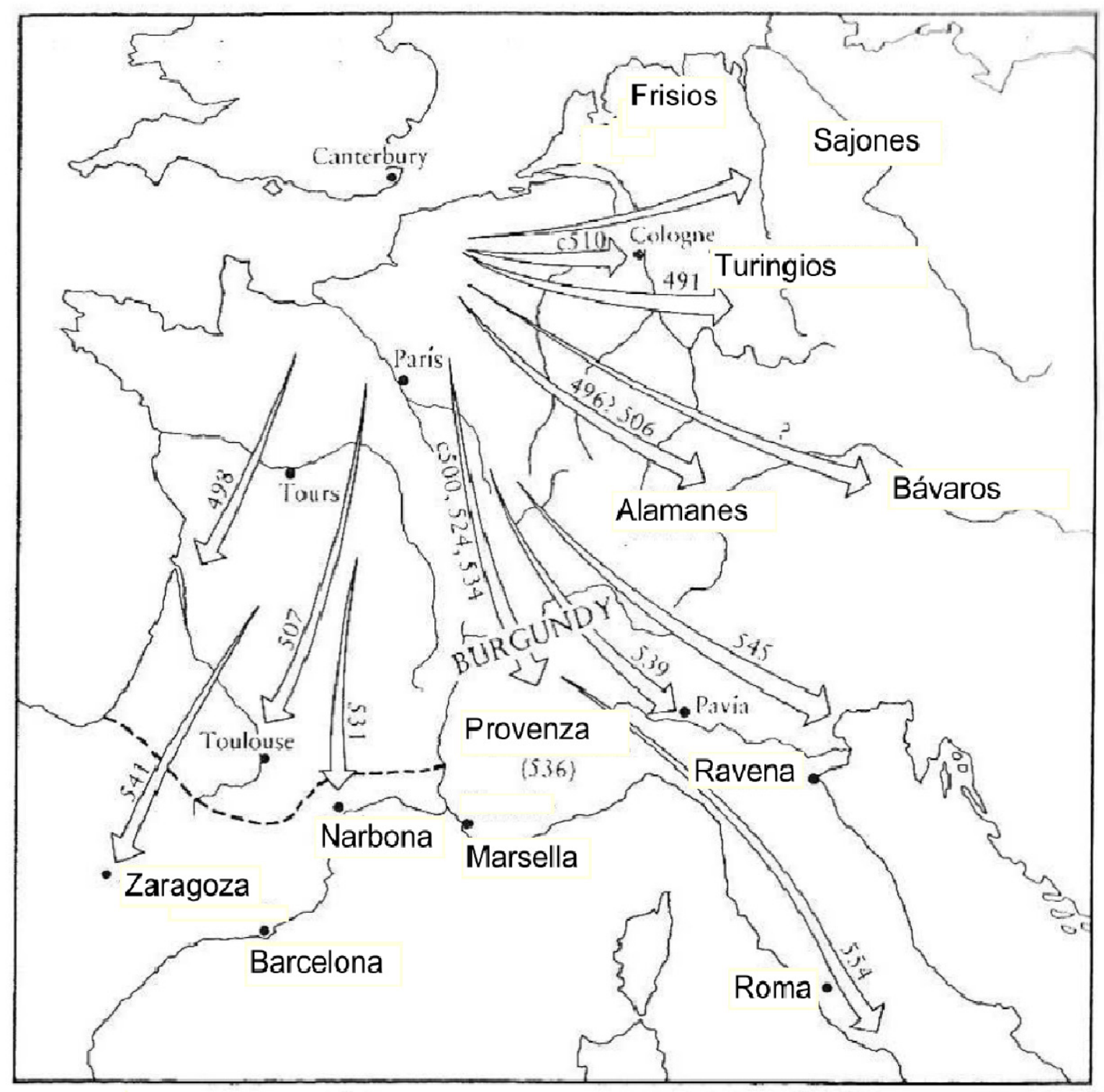

Conquistas francas hasta mediados del siglo $\mathrm{VI}$.

Fuente: James 1988, 95.

Correspondencias: Burgundy/Burgundia; Cologne/Colonia. 


\section{BIBLIOGRAFÍA}

Abreviaturas

CAH, vol. 12: Bowman, A., Garnsey, P. y Cameron, A. (eds.). (2005). The Cambridge Ancient History, vol. 12. Cambridge University Press, Cambridge.

CAH, vol. 13: Cameron, A. y Garnsey, P. (eds.). (1998). The Cambridge Ancient History, vol. 13. Cambridge University Press, Cambridge.

$C A H$, vol. 14: Cameron, A., Ward-Perkins, B. y Whitby, M. (eds.). (2000). The Cambridge Ancient History, vol. 14. Cambridge University Press, Cambridge.

CSEL: Corpus Scriptorum Ecclesiastorum Latinorum.

MGH, AA: Monumenta Germaniae Historica, Auctores antiquissimi.

MGH, LL. nat. Germ.: Monumenta Germaniae Historica, Leges nationum germanicarum.

MGH, SRM: Monumenta Germaniae Historica, Scriptores rerum merovingicarum.

NCMH, vol. 1: Fouracre, P. (ed.). (2005). The new Cambridge Medieval History, vol. 1. Cambridge University Press, Cambridge.

PL: Patrologia latina.

PLRE, 1: Jones, A. H. M., Martindale, J. R. y Morris, J. (1971). The Prosopography of the Later Roman Empire, vol. 1. Cambridge University Press, Cambridge.

PLRE, 2: Martindale, J. R. (1980). The Prosopography of the Later Roman Empire, vol. 2. Cambridge University Press, Cambridge. 


\section{Primaria}

Amiano Marcelino, Res Gestae. Ed. W. Seyfarth (1978), 2 vols., Berlín. Trad. M. L. Harto Trujillo (2002), Historia, Madrid.

Ausonio. Epistulae, Ed. y trad. H. G. Evelyn-White (1919), Ausonius, vol. 2, Cambridge (Massachusetts).

Avito de Vienne, Epistuale. Ed. R. Pieper (1883), MGH, AA, t. 6.2, Berlín, 29-103. Trad. D. Shanzer e I. Wood (2002), Letters and selected prose, Liverpool.

Cesáreo de Arlés, Sermones. Ed. G. Morin (1953), 2 vols., Turnhout. Trad. M. M. Mueller (1956-1972), St. Caesarius of Arles Sermons, 3 vols., Washington.

Casiodoro, Variae. Ed. T. Mommsen (1894), MGH, AA, t. 12, Berlín. Trad. S. J. B. Barnish (1992), Cassiodorus: Variae, Liverpool.

Chronica Gallica A. CCCCLII. Ed. T. Mommsen (1892), MGH, AA, t. 9, Berlín. Trad.

A. C. Murray (2000), From Roman to Merovingian Gaul. A reader, Petersborough, 77-85.

Chronica Galliica A. DXI. Ed. T. Mommsen (1892), MGH, AA, t. 9, Berlín. Trad. A. C. Murray (2000), 98-100.

Chronicarum quae dicuntur Fredegarii scholastici libri IV. Ed. B. Krusch (1888), $M G H, S R M$, t. 2, Hannover. Ed. y trad. (libro IV). O. Devilllers y J. Meyers (2001), Chronique des temps mérovingiens (Livre IV et Continuations), Tournout.

Claudiano, In Rufinum. Ed. y trad. M. Platnauer (1922), Claudian, Cambridge (Massachusetts) y Londres, 24-97.

Concilia Galliae a. 511-695. Ed. y trad. J. Gaudemet y B. Basdevant (1989), Les canons des Conciles Mérovingiens (VI'-VII siècles), París.

Constancio de Lyon, Vita Germani episcopi autisiodorensis. Ed. y trad. R. Borius (1965), Vie de Saint Germain d'Auxerre, París.

Corpus Iuris Civilis. Ed. P. Krueger y otros (1895), 3 vols., Berlín. Trad. S. P. Scott (1932), The Civil Law, Cincinnati.

Enodio de Pavía, Opera. Ed. F. Vogel (1985), $M G H, A A$, t. 7, Berlín.

Epistolae Austrasicae. Ed. W. Gundlach (1892), MGH, Epistolae, t. 3, Berlín, 110-153. 
Formulae Arvernenses. Ed. K. Zeumer (1886), MGH, Formulae Merowingici et Karolini aevi, Hannover, 26-32.

Gregorio de Tours, Decem Libri Historiarum. Ed. B. Krusch y W. Levison (1951). $M G H, S R M$, t. 1.1, Hannover. Trad. L. Thorpe (1974). The history of the franks. Londres.

Gregorio de Tours, Liber in gloria confessorum. Ed. B. Krusch y W. Levison (1885), $M G H, S R M$, t. 1.2, Hannover, 744-820. Trad. R. Van Dam (2004), Glory of the Confessors, Liverpool.

Gregorio de Tours, Liber in gloria martyrum. Ed. B. Krusch y W. Levison (1885), $M G H, S R M$, t. 1.2, Hannover, 484-561. Trad. R. Van Dam (1988). Glory of the Martyrs, Liverpool.

Gregorio de Tours, Liber vitae patrum. Ed. B. Krusch y W. Levison (1885), MGH, $S R M$, t. 1.2, Hannover, 661-744. Trad. E. James (1985), Life of the fathers, Liverpool.

Hilario de Arlés, Sermo De Vita Sancti Honorati Episcopi Arelatensis. Ed. J.-P. Migne (1844-1855), PL, t. 50, París, cols. 1249-1272b.

Hidacio, Continuatio chronicarum Hieronymianorum. Ed. T. Mommsen (1894), MGH, $A A$, t. 11, Berlín, 1-36. Trad. A. C. Murray (2000), 86-98.

Jerónimo, Epistolae. Ed. J.-P. Migne (1865), PL, t. 30, 645-902. Trad. M. A. Freemantle (1892), Jerome: The Principal Works of St. Jerome, Nueva York.

Jordanes, Getica. Ed. T. Mommsen (1882), MGH, AA, t. 5.1, Berlín, 53-138.Trad. O. Devillers (1995), Jordanès. Histoire des Goths, París.

Juan Casiano, Institutiones. Ed. y trad. J.-C. Guy (1965), Institutions cenobitiques, París.

Libanio, Orationes. Ed. y trad. A. F. Norman (1969-1977), Selected Orations, 2 vols., Londres y Cambridge (Massachusetts). 
Liber Contitutionum sive Lex Gundobada et Constitutiones Extravagantes. Ed. L. R. de Salis (1892), MGH, LL. nat. Germ., t. 2.1., Hannover. Trad. K. Fischer Drew (1972), The burgundian code, Pennsylvania.

Mario de Avenches, Chronica a. CCCCLV-DLXXXI. Ed. y trad. J. Favrod (1993), La chronique de Marius d'Avenches, Lausana.

Olimpiodoro, Fragmentos. Ed. y trad. R. C. Blockley (1983), The Fragmentary Classicising Historians of the Later Roman Empire: Eunapius, Olympiodorus, Priscus and Malchus, Liverpool, vol. 2, 152-220.

Orientius Auscensis, Commonitorium. Ed. J.-P. Migne (1847), PL, t. 61, París, 9771006. Trad. L. Bellanger (1902), Étude sur le poème d'Orientius, París.

Pactus legis salicae. Ed. K. A. Eckhardt (1962), MGH, LL. nat. Germ., t. 4.1. Hannover. Trad. K. Fischer Drew (1991), The Laws of the Salian Franks, Filadelfia.

Panegyrici latini. Ed. y trad. E. Galletier (1949-55), Panégirics latins, 3 vols., París.

Paulino de Béziers, Epigramma. Ed. C. Schenkl (1888), CSEL, t. 16, Viena, 503-505.

Paulino de Pella, Eucharisticus. Ed. y trad. H. G. Evelyn-White (1921), Ausonius, vol.

2, Cambridge (Massachusetts).

Paulino de Nola, Epistulae. Ed. G. de Hartel (1894), Sancti Pontii Meropii Paulini Nolani Epistulae, CSEL, t. 29, Viena.

Paulo Orosio, Historiae adversus paganos. Ed. C. Zangemeister (1882), Pauli Orosii Historiarum Adversum paganos libri VII, CSEL, t. 5, Viena. Trad. E. Sánchez Salor (1982), Paulo Orosio. Historias, 2 vols., Madrid.

Plinio, Epistulae. Ed. y trad. B. Radice (1927-1931), Letters and Panegyricus, 2 vols., Cambridge (Massachusetts). Trad. J. C. Martín (2007), Plinio el Joven. Epistolario (Libros I-IX). Panegírico del Emperador Trajano, Madrid.

Prisco, Fragmentos. Ed. y trad. R. C. Blockley (1983), vol. 2, 222-379.

Próspero de Aquitania, Carmen de Providentia Dei. Ed. y trad. M. Markovich (1989), Prosper of Aquitaine. De Providentia Dei, Leiden. Ed. y trad. R. Villegas Martín (2010), Pseudo-Próspero de Aquitania. Sobre la Providencia de Dios, Barcelona. 
Próspero de Tiro, Epitoma de chronicon. Ed. T. Mommsen (1892), MGH, AA, t. 9, Berlín, 385-485. Trad. A. C. Murray (2000), 62-76.

Querolus. Ed y trad. C. Jacquemard-Le-Laos (1994), Querolus (Aulularia). Le Grincheux (comédie de la petite marmite), París.

Ruricio de Limoges, Epistulae. Ed. B. Krusch (1887), MGH, AA, t. 8, Berlín. Trad. R. Mathisen (1999), Ruricius of Limoges and Friends. A Collection of Letters from Visigothic Gaul, Liverpool.

Rutilio Namaciano, De reditu Suo. Ed. y trad. J. W. Duff y A. M. Duff (1934), Minor Latin Poets, Cambridge (Massachusetts), 764-829. Trad. A. García-Toraño Martínez (2002), Rutilio Namaciano. El retorno. Geógrafos latinos menores, Madrid, 43-82.

Salviano de Marsella, Operae. Ed. y trad. G. Lagarrigue (1975), Salvien de Marseille. Oeuvres, 2 vols., París.

Sidonio Apolinar, Epistulae et Carmina. Ed. y trad. W. B. Anderson (1936-65), Poems and letters, 2 vols., Cambridge (Massachusetts).

Sozomeno, Historia Ecclesiastica. Ed. y trad. A.-J. Festugière y B. Grillet (1983-2008), Sozomène. Histoire Ecclesiastique, 4 vols., París.

Sulpicio Severo, Operae. Ed. K. Halm (1866), Sulpicii Severi Opera, CSEL, vol. 1, Viena. Trad. A. Roberts (1994), The Works of Sukpitius Severus, Nicene and Post-Nicene Fathers, vol. 11, Peabody, 1-122.

Tácito, Germania. Ed. y Trad. J. Perret (1997), Tacite. La Germanie, París.

Theodosiani libri XVI cum Constitutionibus Sirmondianis et Leges novellae ad Theodosianum pertinentes. Ed. T. Mommsen y P. M. Meyer (1905), Berlín. Trad. C. Pharr y otros (1952), The Theodosian Code and Novels and the Sirmondian Constitutions, Nueva Jersey.

Vita Genovefae virginis Parisiensis. Ed. B. Krusch (1896), MGH, SRM, t. 2, Hannover, 215-238. 
Vita sancti Caesarii Episcopi Arelatensis. Ed. B. Krusch (1888), MGH, SRM, t. 3, Hannover, 433-501.

Vitae Patrum Iurensis. Ed. y trad. F. Martine (1968), Vie des Pères du Jura, París.

Victor de Vita, Historia persecutionis Africanae provinciae. Ed. y trad. S. Lancel (2002), Histoire de la persécution vandale en Afrique, París, 93-212.

Zósimo, Historia Nova. Trad. J. M. Candau Morón (1992), Nueva Historia, Madrid.

Secundaria

Alföldy, G. (1987). Historia social de Roma. Alianza, Madrid.

Amin, S. [1973] (1986). El desarrollo desigual. Planeta-De Agostini, Barcelona.

Anderson, P. [1974] (1995). Transiciones de la Antigüedad al feudalismo, Siglo XXI, Madrid.

Arnheim, M. T. W. (1972). The senatorial aristocracy in the Later Roman Empire. Clarendom Press, Oxford.

Astarita, C. (1994). "La discutida universalidad del Modo de Producción Tributario". Studia Historica. Historia medieval, 12, 191-201.

Astarita, C. (2001). "Historia y Ciencias Sociales. Préstamos y reconstrucción de categorías analíticas”. Sociohistórica, 8, 13-43.

Astarita, C. (2007). "Construcción histórica y construcción historiográfica de la temprana Edad Media”. Studia historica. Historia medieval, 25, 247-269.

Astarita, C. (inédito). “Orígenes del artesano medieval”.

Bachrach, B. S. (1972). Merovingian military organization. 481-751. University of Minnesota Press, Minneapolis.

Bachrach, B. S. (1973). A history of the alans in the west. From Their First Appearance in the Sources of Classical Antiquity through the Early Middle Ages. University of Minnesota Press, Minneapolis.

Bachrach, B. S. (2010). "The fortification of Gaul and the Economy of the Third Century". Journal of Late Antiquity, 3/1, 38-64. 
Banaji, J. (2011). "Late Antiquity to the Early Middle Ages: What Kind of Transition?". Historical Materialism, 19/1, 109-144.

Bang, P. F. (1997). “Antiquity between 'primitivsm' and 'modernism'. The revival of ‘modernism"”. Versión electrónica en www.hum.au.dk/ckulturf/pages/publications/pfb/antiquity.htm.

Bang, P. F. (2008). The Roman Bazaar. Cambridge University Press, Cambridge.

Barbero, A. y Loring, M. I. (2005). "The formation of the Sueve and Visigothic kingdoms in Spain". En NCMH, vol. 1, 162-192.

Barnish, S., Lee, A. D. y Whitby M. (2000). "Government and administration". En CAH, vol. 14, 164-206.

Baynes, N. (1922). "Stillicho and the barbarian invasions". Journal of Roman Studies, $12,207-220$.

Birley, A. R. (2005). The Roman Government of Britain. Oxford University Press, Oxford.

Bloch, M. [1947] (1989). “Cómo y porqué terminó la esclavitud antigua”. En AA. VV. La transición del esclavismo al feudalismo. Akal, Madrid, 159-194.

Blockley, R. C. (1998). “The dynasty of Theodosius”. En CAH, vol. 13, 111-137.

Bondue, D. (2011). De servus à sclavus. La find de l'esclavage (371-918). Presses de l’Université Paris-Sorbonne, París.

Bowersock, G. W. (1996). "The Vanishing Paradigm of the Fall of Rome”. Bulletin of the American Academy of Arts and Sciences, 49/8, 29-43.

Bowes, K. y Gutteridge, A. (2005). "Rethinking the later Roman landscape". Journal of Roman Archaeology, 18, 405-413.

Bonifay. M. y Raynaud, C. (2007). "Échanges et consommation”. Gallia, 64, 93-161.

Bonnassie, P. (1991). "Supervivencia y extinción del régimen esclavita en el occidente de la alta Edad Media (siglos IV-XI)”. En Bonnassie, P. Del esclavismo al feudalismo en Europa occidental. Crítica, Barcelona, 13-75.

Brion Davis, B. (2006). Inhuman Bondage: The Rise and Fall of Slavery in the New World. Oxford University Press, Oxford.

Brown, P. [1971] (1989). El mundo en la Antigüedad tardía. Taurus, Madrid.

Brown, P. [1978] (1993). The making of late antiquity. Harvard University Press, Cambridge (Massachusetts). 
Burns, T. S. (1992). "The settlement of 418”. En Drinkwater, J. F. y Elton, H. (eds.). Fifth-Century Gaul: A crisis of identity? Cambridge University Press, Cambridge, 53-63.

Cameron, A. (1998). El mundo mediterráneo en la Antigüedad Tardía (395-600). Crítica, Barcelona.

Campbell, B. (2005). “The army”. En CAH, Vol. 12, 110-130.

Carrié, J.-M. (1976). "Patronage et propriété militaires au IV S. Objet rhétorique et objet réel du Discours sur les patronages de Libanius". Bulletin de Correspondance Hellenique, 100, 159-176.

Carrié, J.-M. (1982). “Le 'colonat du Bas-Empire’: un mythe historiographique?”. Opus. Rivista internazionale per la storia economica e sociale dell'antichità, 1, 351-370.

Carrié, J.-M. (1983). "Un roman des origines: les genealogies du 'colonat du BasEmpire"”. Opus. Rivista internazionale per la storia economica e sociale dell'antichità, 2, 205-51.

Carrié, J.-M. y Rousselle, A. (1999). L’Empire romain en mutation. Des Sévères á Constantin, 192-337. Seuil, París.

Carru, D. y otros (2001). "Les villae en Provence aux IV et V $V^{\mathrm{e}}$ siècles: apports et limites des inventaires archéologiques". En Ouzoulias, P. y otros (dirs.). Les campagnes de la Gaule à la fin de l'Antiquité. Actes du IV colloque de l'association AGER. Éditions APDCA, Antibes, 475-501.

Cerati, A. (1975). Caractère annonaire et assiette de l'impôt foncier au Bas-Empire. Librairie générale de droit et de jurisprudence R. Pichon et R. Durand- Auzias, París.

Chayanov, A. V. [1924] (1981). Sobre la teoría de los sistemas económicos no capitalistas. En AA. VV. Chayanov y la teoría de la economía campesina. Cuadernos de Pasado y Presente, México, 49-76.

Chayanov, A. V. [1925] (1985). La organización de la unidad económica campesina. Nueva Visión, Buenos Aires.

Clover, F. M. [1973]. “Geiseric and Attila”. Reimpreso en Clover, F. M. (1993). The Late Roman West and the Vandals. Variorum Collected Studies, Aldershot, 104-117. 
Collins, R. (2000). “The western kingdoms". En CAH, vol. 14, 112-134.

Corbier, M. (2005). "Coinage and taxation: the State's point of view”. En CAH, vol. 12, 327-392.

Cortés, F. y Cuéllar, O. (1986). "Lenin y Chayanov, dos enfoques no contradictorios". Nueva Antropología, 31, 63-101.

Courcelle, P. (1948). Histoire littéraire des grandes invasions germaniques. Librairie Hachette, París.

Curran, J. (1998). "From Jovian to Theodosius". En CAH, vol. 13, 78-110.

da Graca, L. (2008). "Reflexiones metodológicas sobre el estudio comparativo de Chris Wickham". Edad Media. Revista de Historia, 9, 265-297.

Davies, W. (1996). “On servile status in the Early Middle Ages”. En Bush, M. L. (ed.). (1996). Sefdom and Slavery: studies in legal bondage. Longman, Londres y Nueva York, 225-246.

de Ste. Croix, G. E. M. (1988). La lucha de clases en el mundo griego antiguo. Crítica, Barcelona.

Delaplace, Ch. (2001). "Débats et problèmes. Introduction au colloque”. En Ouzoulias, P. y otros (dirs.). Op. cit., 15-20.

Demougeot, E. [1970]. “A propos des lètes gaulois du IV siècle”. Reimpreso en Demougeot, E. (1988). L'Empire romain et les barbares d'occident (IV -VII siècles). Publications de la Sorbonne, París, 61-74.

Devroey, J.-P. (2002). “La economía”. En McKitterick, R., La alta Edad Media. Crítica, Barcelona, 107-139.

Devroey, J.-P. (2003). Économie rurale et société dans l'Europe franque (VI $-I X^{e}$ siècles). Tome 1. Fondements matériels, échanges et lien social. Editions Belin, París.

Devroey, J.-P. (2006). Puissants et misérables. Système social et monde paysan dans l'Europe des Francs (VIe-IXe siècles). Académie royale de Belgique, Bruselas.

Doehaerd, R. (1974). Occidente durante la alta Edad Media. Economías y sociedades. Labor, Barcelona.

Dopsch, A. [1918/1920] (1982). Fundamentos económicos y sociales de la cultura europea (de César a Carlomagno). Fondo de Cultura Económica, Madrid. 
Drinkwater, J. F. (1983). Roman Gaul: The three provinces, 58 BC-AD 260. Cornell University Press, Ithaca.

Drinkwater, J. F. (1989). "Patronage in Roman Gaul and the problem of the Bagaudae". En Wallace-Hadrill, A. (ed.). Patronage in Ancient Society. Routledge, Londres, 189-203.

Drinkwater, J. F. (1992). “The Bacaudae of fifth-century Gaul”. En Drinkwater, J. F. y Elton, H. (eds.). Op. cit., 208-217.

Drinkwater, J. F. (1998). "The usurpers Constantine III (407-411) and Jovinus (411413)". Britannia, 29, 269-298.

Duby, G. [1973] (1996). Guerreros y campesinos. Desarrollo inicial de la economía europea (500-1200). Siglo XXI, Madrid.

Dunn, M. (2000). The emergence of Monasticism. From the Desert Fathers to the Early Middle Ages. Blackwell Publishing, Oxford.

Durand, A. y Leveau, Ph. (2004). "Farming in mediterranean France and rural settlement in the late roman and early medieval periods: the contribution from archaeology and environmental sciences in the last twenty years (1980-2000)”. En Barceló, M. y Sigaut, F. (eds.). The making of Feudal Agricultures? Brill, Leiden y Boston.

Durliat, J. (1990). Les finances publiques de Dioclétien aux carolingiens (284-889). Jan Thorbecke Verlag, Sigmaringen.

Durliat, J. (1998). "Les conditions du commerce au VIe siècle". En Hodges, R. y Bowden W. (eds.). The sixth century. Production, distribution and demand. Brill, Leiden, 1998, 89-118.

Dyson, S. L. (2003). The roman countryside. Duckworth, Londres.

Elton, H. (1992). "Defence in fifth-century Gaul". En Drinkwater, J. F. y Elton, H. (eds.). Op. cit., 177-183.

Favrod, J. (2002). Les bourgondes. Un royaume oublié au cœur de l'Europe. Presses polytechniques et universitaires romandes, Lausana.

Fernández Ubiña, J. A. (1982). La crisis del siglo III y el fin del mundo antiguo. Akal, Madrid. 
Finley, M. I. [1973] (1986). La economía de la Antigüedad. Fondo de Cultura Económica, México D. F.

Finley, M. I. (1982). Esclavitud antigua e ideología moderna, Crítica, Barcelona.

Fixot, M. (2000). "La cité et son territoire: l'exemple du sud-est de la Gaule”. En Brogiolo, G. P., Gauthier, N. y Christie, N. (eds.). Towns and their territories between Late Antiquity and the Early Middle Ages. Brill, Leiden, 37-62.

Flory, T. (1979). "Fugitive Slaves and Free Society: The Case of Brazil". The Journal of Negro History, 64/2, 116-130.

Fourquin, G. (1975). "Le premier Moyen Âge". En Duby, G. (dir.). Histoire de la France rurale, vol. 1, La formation des campagnes française des origines au $X I V^{e}$ siècle. Seuil, París.

Frank, R. I. (1972). “Ammianus on Roman taxation". The American Journal of Philology, 93/1, 69-86.

García Mac Gaw, C. G. (2003a). “Conclusiones. Sobre la importancia de los elementos superestructurales en la caracterización de los modos de producción”. Anales de Historia Antigua, Medieval y Moderna, 35-36, 219-232.

García Mac Gaw, C. G. (2003b). "Roma: La crisis del siglo III y el modo de producción tributario". Anales de Historia Antigua, Medieval y Moderna, 35-36, 97-119.

García Mac Gaw, C. G. (2006). "La transición del esclavismo al feudalismo y la villa esclavista". Dialogues d'histoire ancienne, 32/2, 27-41.

García Mac Gaw, C. G. (en prensa). “The Slave Roman Economy and the Plantation System”. En Da Graca, L. y Zingarelli, A. (eds.). Studies on pre-capitalist modes of production. Brill, Leiden-Boston.

Garnsey, P. (1998). "Peasants in ancient roman society". En Garnsey, P. Cities, Peasants and Food in Classical Antiquity. Essays in Social and Economic History. Cambridge University Press, Cambridge, 91-106.

Garnsey, P. (2003). "El campesinado: subsistencia y supervivencia”. En Gallego, J. (ed.). El mundo rural en la Grecia antigua. Akal, Madrid, 71-102.

Garnsey, P. y Saller, R. (1991). El imperio romano. Economía, sociedad y cultura. Crítica, Barcelona.

Garnsey, P. y Woolf, G. (1989). "Patronage of the Rural Poor in the Roman World". En Wallace-Hadrill, A. (ed.). Op. cit., 162-167. 
Geary, P. (1988). Before France and Germany. The Creation and Transformation of the Merovingian World. Oxford University Press, Nueva York.

Gerberding, R. A. (1987). The Rise of the Carolingians and the Liber Historiae Francorum. Oxford University Press, Oxford.

Gellner, E. (1985). "Patrones y clientes”. En Gellner, E. y otros. Patronos y clientes en las sociedades mediterráneas. Ediciones Jucar, Barcelona, 9-15.

Giardina, A. (2007). "The transition to late antiquity". En Scheidel, W., Morris, I. y Saller, R. (eds.). The Cambridge Economic History of the Greco-Roman World. Cambridge University Press, Cambridge, 743-768.

Gilliard, F. D. (1979). “The senators of sixth-century Gaul”. Speculum, 54/4, 685-697.

Goffart, W. [1972]. "From Roman Taxation to Medieval Seigneurie: Three Notes". Reimpreso en Goffart, W. (1989). Rome's fall and after. The Hambledon Press, Londres y Ronceverte, 167-211.

Goffart, W. (1974). Caput and Colonate: Towards a history of late roman taxation. University of Toronto Press, Toronto.

Goffart, W. (1980). Barbarians and Romans (AD 418-584). The techniques of accommodations. Princeton University Press, Princeton.

Goffart, W. [1981]. "Rome, Constantinople, and the Barbarians". Reimpreso en Goffart, W. (1989), 1-32.

Goffart, W. [1982a]. "Merovingian Polyptychs: Reflections on Two Recent Publications". Reimpreso en Goffart, W. (1989), 233-253.

Goffart, W. [1982b]. “Old and new in Merovingian taxation”. Reimpreso en Goffart, W. (1989), 213-231.

Goffart, W. [1989]. "The Theme of 'The Barbarian Invasions' in Later Antique and Modern Historiography”. Reimpreso en Goffart, W. (1989), 111-132.

Goffart, W. (2006). Barbarian Tides. The Migration Age and the Later Roman Empire. University of Pennsylvania Press, Filadelfia.

Goffart, W. (2009). "Salvian of Marseille, De Gubernatione Dei 5.38-45 and the 'colonate' problem. Antiquité tardive, 17, 269-288.

Golvers, N. (1984). “Le Querolus et le parler de Marseille”. Latomus, 43/2, 432-437.

Grey, C. (2006). "Salvian, the ideal Christian community and the fate of the poor in fifth-century Gaul”. En Atkins, M. y Osborne, R. Poverty in the Roman World. Cambridge University Press, Cambridge, 162-182. 
Guyon, J. (2001). "De la ville à la campagne". En Ouzoulias, P. y otros (dirs.). Op. cit., 569-585.

Haldon, J. (1993). The State and the Tributary Mode of Production. Verso, Londres.

Halsall, G. (1992). "The origins of the Reihengräberzibilsation: forty years on". En Drinkwater, J. F. y Elton, H. (eds.). Op. cit., 196-207.

Halsall, G. (1998). "Violence and society: an introductory survey. En Halsall, G. (ed.). Violence and Society in the Early Medieval West. The Boydell Press, Woodbridge, 1-45.

Halsall, G. (2003). Warfare and Society in the Barbarian West, 450-900. Routledge, Londres y Nueva York.

Halsall, G. (2007). Barbarian Migrations and the Roman West, 376-568. Cambridge University Press, Cambridge.

Harper, K. (2011). Slavery in the Late Roman World. AD 275-425. Cambridge University Press, Cambridge.

Harries, J. (1994). Sidonius Apollinaris and the fall of Rome. AD 407-485. Clarendon Press, Oxford.

Harries, J. (1999). Law and Empire in Late Antiquity. Cambridge University Press, Cambridge.

Heather, P. (1991). Goths and Romans. 332-489. Oxford Historical Monographs, Oxford.

Heather, P. (1995). "The Huns and the End of the Roman Empire in Western Europe". The English Historical Review, 110/435, 4-41.

Heather, P. (1998). "Senators and senates". En $C A H$, vol. 13, 184-210.

Heather, P. (2000). "State, Lordship and Community in the West (c. A. D. 400-600)". En $C A H$, vol. 14, 473-468.

Heather, P. (2006). La caída del Imperio Romano. Crítica, Barcelona.

Heather, P. (2010). Emperadores y bárbaros. El primer milenio de la historia de Europa. Crítica, Barcelona.

Henning, J. (2008). "Strong rulers - Weak Economy? Rome, the Carolingians and the Archaeology of Slavery in the First Millenium AD”. En Davis, J. R. y McCormick, M. (eds.). The Long Morning of Medieval Europe. New Directions in Early Medieval Studies. Ashgate, Aldershot, 33-53. 
Heynig, K. (1982). "Principales enfoques sobre la economía campesina". Revista de la CEPAL, 16, 115-142.

Hitchner, R. B. (1992). "Meridional Gaul, trade and the Mediterranean economy in late Antiquity”. En Drinkwater, J. F. y Elton, H. (eds.). Op. cit., 122-131.

Hopkins, K. (1980). "Taxes and Trade in the Roman Empire (200 B. C.-A. D. 400)". The Journal of Roman Studies, 70, 101-125.

Hopkins, K. [1995]. "Rome, Taxes, Rent and Trade". Reimpreso en Scheidel, W. y Von Reden, S. (eds.). (2002). The Ancient Economy. Routledge, Nueva York, 190230.

Innes, M. (2006). "Land, freedom and the making of the medieval West". Transactions of the Royal Historical Society, 16, 39-74.

James, E. (1988). The Franks. Blackwell, Oxford.

Jones, A. E. (2009). Social Mobility in Late Antique Gaul: Strategies and Opportunities for the non-elite. Cambridge University Press, Cambridge y Nueva York.

Jones, A. H. M. (1957). “Capitatio and Iugatio”. The Journal of Roman Studies, 47/1-2, 88-94.

Jones, A. H. M. [1958] (1981). "El colonato romano”. En Finley, M. I. (ed.). Estudios sobre historia antigua. Akal, Madrid, 315-331.

Jones, A. H. M. (1964). The Later Roman Empire 284-602. A Social Economic and Administrative Survey. Basil Blackwell, Oxford.

Jones, A. H. M. (1968). Studies in Roman Government and Law. Barnes \& Noble, Nueva York.

Jordán Montés, J. F. (1997). "Las curias en el reinado de Honorio (395-425 d. C.). Tradición y mutación”. Antigüedad y cristianismo, 14, 97-133.

Kehoe, D. P. (2007). “The early Roman empire: Production”. En Scheidel, W., Morris, I. y Saller, R. (eds.). Op. cit., 543-569.

Kelly, C. (1998). "Emperors, government and bureaucracy”. En CAH, vol. 13, 138-183. Klingshirn, W. E. (1994). The making of a Christian Community in Late Antique Gaul. Cambridge University Press, Cambridge. 
Kuchenbuch, L. y Michael, B. [1977] (1986). "Estructura y dinámica del modo de producción 'feudal' en la Europa preindustrial". Studia Historica. Historia Medieval, 4/2, 7-57.

Kulikowski, M. (2000). “Barbarians in Gaul, Usurpers in Britain”. Britannia, 31, 325345.

Kulikowski, M. (2001). "The Vsigothic Settlement in Aquitania: the Imperial Perspective". En Mathisen, R. W. y Shanzer, D. (eds.). Society and Culture in Late Antique Gaul. Revisiting the Sources. Ashgate, Aldershot, 26-38.

Kulikowski, M. (2004). Late Roman Spain and Its Cities. The Johns Hopkins University Press, Baltimore.

Kulikowski, M. (2007). Rome's Gothic Wars. From the Third Century to Alaric. Cambridge University Press, Cambridge.

Lavan, L. (2003). "Late Antique Archaeology: an introduction". En Lavan, L. y Bowden, W. (eds.). Theory and Practice in Late Antique Archaeology. Brill, Leiden y Boston, vii-xvi.

Lambert, D. (2000). “The barbarians in Salvian's De gubernatione Dei”. En Mitchell, S. y Greatrex, G. (eds.). Ethnicity and Culture in Late Atiquity. Duckworth/The Classical Press of Wales, Londres, 103-115.

Le Glay, M. (1975). "La Gaule romanisée". En Duby, G. (ed.). Histoire de la France rurale, t. 1. Seuil, París, 203-316.

Lebecq, S. (1990). Les origines franques. Seuil, París.

Lebecq, S. (1998). "Les echanges dans la Gaule du Nord au VIe siècle”. En Hodges, R. y Bowden, W. (eds.). The sixth century. Production, distribution and demand. Brill, Leiden, 185-202.

Lee, A. D. (1998). “The army”. En $C A H$, vol. 13, 211-237.

Lee, A. D. (2007). War in late antiquity. A social history. Oxford University Press, Oxford.

Lepelley, C. (1983). “Quot curiales, tot tyranny. L’image du décurion oppresseur au bas-empire”. En Frézouls, E. (ed.). Crise et redressement dans les provinces européennes de l'Empire (milieu du III -milieu du IV siècle ap. J.-C.). Actes du colloque de Strabourg (décembre 1981). AECR, Estrasburgo, 143-156. 
Leveau, Ph. (2002). "Introduction: Les incertidumbres du terme villa et la question du vicus en Gaule Narbonnaise". Revue archéologique de Narbonnaise, 35, 5-26.

Leveau, Ph. (2007). “The western provinces”. En Scheidel, W., Morris, I. y Saller, R. (eds.). Op. cit., 651-670.

Lewitt, T. (2003). “'Vanishing Villas': what happened to elite rural habitation in the West in the $5^{\text {th }}$ and $6^{\text {th }}$ centuries A.D.?". Journal of Roman Archaeology, 16, 260-275.

Liebeschuetz, J. H. W. G. (1990). Barbarians and bishops. Army, Church, and State in the Age of Acrcadius and Chrysostom. Clarendon Paperbacks, Oxford.

Liebeschuetz, J. H. W. G. (1997). "Cities, taxes and accomodation of barbarians: the theories of Durliat and Goffart”. En Pohl, W. (ed.). Kingdoms of the Empire: The Integration of Barbarians in Late Antiquity. Brill, Leiden.

Liebeschuetz, J. H. W. G. (2000). "Administration and politics in the cities of the fifth to the mid seventh century: 425-640". En $C A H$, vol. 14, 207-237.

Liebeschuetz, J. H. W. G. (2001). Decline and Fall of the Roman City. Oxford University Press, Oxford.

Loseby, S. T. (1992). “Marseille: A Late Antique Success Story?”. The Journal of Roman Studies, 82, 165-185.

Loseby, S. T. (2005). “The Mediterranean Economy”. En NCMH, vol. 1, 605-638.

Luporini, C. y otros (1986). El concepto de "formación económico-social”. Cuadernos de Pasado y Presente, México D. F.

MacMullen, R. (1987). “Late Roman Slavery”. Historia, 36/3, 359-382.

Maenchen-Helfen, O. J. (1973). The World of the Huns. Studies in Their History and Culture. University of California Press, Berkeley, Los Ángeles y Londres.

Marcone, A. (1998). “Late roman social relations”. En CAH, vol. 13, 338-370.

Mathisen, R. W. (1989). Ecclesiastical Factionalism and Religious Controversy in fifthcentury Gaul. The Catholic University of America Press, Washington D. C.

Mathisen, R. W. (1993). Roman aristocrats in barbarian Gaul. Strategies for survival in an age of transition. University of Texas Press, Austin.

Matthews, J. F. (1975). Western Aristocracies and Imperial Court. A. D. 364-425. Clarendon Press, Oxford. 
Matthews, J. F. (2001). Laying Down the Law: A Study of the Theodosian Code. Yale University Press, New Haven y Londres.

Mazzarino, S. (1942). Stilicone: La crisi imperiale dopo Teodosio. Studi pubblicati dal R. Instituto Italiano per la Storia Antica, Roma.

McCormick, M. (2001). Origins of the European Economy: Communications and Commerce, A. D. 300-900. Cambridge University Press, Cambridge.

Merrills, A. y Miles, R. (2010). The Vandals. Wiley-Blackwell, West Sussex.

Moorhead, J. "The Byzantines in the West in the sixth century". En NCMH, vol. 1, 118139.

Nixon, C. E. V. (1992). "Relations between Visigoths and Romans in fifth-century Gaul”. En Drinkwater, J. F. y Elton, H. (eds.). Op. cit., 64-74.

Nouailhat, R. (1988). Saints et Patrons. Les premiers moines de Lérins. Les Belles Lettres, París.

O'Flynn, J. M. (1983). Generalissimos of the Western Roman Empire. University of Alberta, Edmonton.

Ode, B. y Odiot, T. (2001). "L'habitat rural de la moyenne vallé du Rhône aux IV et $V^{\mathrm{e}}$ siècles". En Ouzoulias, P. y otros (dirs.). Op. cit., 225-246.

Panella, C. (1993). "Merci e scambi nel Mediterraneo in età tardoantica". En Sotira di Roma, t. 3, L'età tardoantica, vol. 2, I Luoghi e le culture. Giulio Einardi Editore, Turín, 613-697.

Pellecuer, Ch. y Pomarèdes, H. (2001). "Crise, survie ou adaptation de la villa romaine en Narbonnaise première? Contribution des récentes recherches de terrain en Languedoc-Rousillon”. En Ouzoulias, P. y otros (dirs.). Op. cit., 503-532.

Percival, J. (1992). “The fifth-century villa: new life or death postponed?". En Drinkwater, J. F. y Elton, H. (eds.). Op. cit., 156-164.

Piganiol, A. (1947). L'Empire Chrétien (325-395). Presses Universitaires de France, París.

Pirenne, H., [1935] (1977). Mahoma y Carlomagno. Alianza, Madrid. 
Rapp C. (2005). Holy Bishops in Late Antiquity. The Nature of Christian Leadership in an Age of Transition. University of California Press, Berkeley, Los Ángeles y Londres.

Rathbone, D. W. (1996). “The imperial finances”. En Bowman, A. K., Champlin, E. y Lintott, A. (eds.). The Cambridge Ancient History, vol. 10, 309-323.

Raynaud, C. (2001). “L'occupationes des grottes en Gaule méditerranéenne, à la fin de 1'Antiquité'. En Ouzoulias, P. y otros (dirs.). Op. cit., 449-471.

Rio, A. (2009). Legal Practice and the Written Word in the Early Middle Ages. Frankish Formulae, c. 500-1000. Cambridge University Press, Cambridge.

Ripoll, G. y Arce, J. (2001). “Transformación y final de las villae en occidente (siglos IV-VIII): problemas y perspectivas”. Arqueología y territorio, 8, 21-54.

Roberts, M. (1992). "Barbarians in Gaul: the response of the poets". En Drinkwater, J. F. y Elton, H. (eds.). Op. cit., 97-107.

Rostovtzeff, M. I. [1926] (1937). Historia social y económica del imperio romano. Espasa-Calpe, Madrid.

Rouche, M. (1979), L'Aquitaine: des Wisigoths aux Arabes, 418-781: Naissance d'une région. École des Hautes Études en Sciences Sociales, París.

Sahlins, M. (1983). Economía de la Edad de Piedra. Akal, Madrid.

Saller, R. (1982). Personal patronage under the early Empire. Cambridge University Press, Cambridge.

Salzman, M. R. (2002). The Making of a Christian Aristocracy. Social and Religious Change in the Western Roman Empire. Harvard University Press, Cambridge (Massachusetts) y Londres.

Samson, R. (1989). "Rural Slavery, Inscriptions, Archaeology and Marx: A Response to Ramsay MacMullen's 'Late Roman Slavery'”. Historia, 38, 99-110.

Samson, R. (1992). "Slavery, the roman legacy". En Drinkwater, J. F. y Elton, H. (eds.). Op. cit., 218-227.

Sanchez León, J. C. (1996a). Los bagaudas: rebeldes, demonios, mártires. Revueltas campesinas en Galia e Hispania durante el bajo imperio. Publicaciones de la Universidad de Jaén, Jaén.

Sanchez León, J. C. (1996b). Les sources de l'histoire des bagaudes. Traduction et Commentaire. Presses Universitaires de Franche-Comté, Besançon. 
Santos, D. (2006). "Los mercaderes de la Galia en la Antigüedad tardía". Anales de Historia Antigua, Medieval y Moderna, 39, 203-214.

Santos, D. (2011). "La economía política de la Galia tardoantigua”. III Jornadas Nacionales de Historia Antigua - II Jornadas Nacionales de Historia Antigua. Universidad Nacional de Córdoba, Córdoba, 157-166.

Sanz Huesma, F. J. (2005). "Usurpaciones en Britania (406-407): hipótesis sobre sus causas y protagonistas”. Gerión, 23/1, 315-324.

Sarachu, P. (2005). Las relaciones de patronazgo en la Galia romana (siglos IV-V). Tesis de Licenciatura. Universidad Nacional de La Plata, La Plata.

Sarachu, P. (2009). "Las relaciones de patronazgo en la Galia (siglos IV-V)”. Anales de Historia Antigua, Medieval y Moderna, 41, 147-175.

Sarachu, P. (2011a). "Esclavos sin esclavismo: la inestabilidad de la explotación servil en el reino burgundio". Circe de clásicos y modernos, 15, 159-173.

Sarachu, P. (2011b). "Problemas de definición en torno al patronazgo rural en la Galia tardorromana”. En Campagno, M., Gallego, J. y García Mac Gaw, C. G. El estado en el Mediterráneo antiguo. Egipto, Grecia, Roma. Miño y Dávila, Buenos Aires, 409-431.

Sarachu, P. (2013). "Perception fiscale, patronage rural et genèse d'une société de base paysanne. Le sud de la Gaule vers la fin de l'Empire romain”. Dialogues d'Histoire Ancienne, 38/2.

Scheidel, W. (2007). "Demography”. En Scheidel, W., Morris, I. y Saller, R. (eds). Op. cit., 38-86.

Schneider, L. (2001). "Oppida et castra tardo-antiques: à propos des établissements de hauteur de la Gaule méditerranéenne". En Ouzoulias, P. y otros (dirs.). Op. cit., 433-448.

Schwarcz, A. (2001). "The Visigothic Settlement in Aquitania: Chronology and Archaeology”. En Mathisen, R. W. y Shanzer, D. (eds.). Op. cit., 5-25.

Shanin, T. (1971). "Peasantry: delineation of a sociological concept and a field of study”. Archives Europèenes de Sociologie/ European Journal of Sociology, 12/2, 289-300.

Shanzer, D. y Mathisen, R. W. “Introduction”. En Mathisen, R. W. y Shanzer, D. (eds.). Op. cit., 1-14. 
Smith, J. M. H. (2005). Europe after Rome. A new cultural history. 500-1000. Oxford University Press, Oxford.

Sodini, J.-P. (2003). “Archaeology and Late Antique Social Structures”. En Lavan, L. y Bowden, W. (eds.). Op. cit., 25-56.

Staerman, E. M. [1952] (1989). "La caída del régimen esclavista”. En AA. VV. Op. cit., $59-129$.

Tannenbaum, N. (1984). "Chayanov and economic antropology". En Durrenberg, E. P. (ed.). Chayanov, peasants and economic anthropology. Academic Press, San Diego, 27-38.

Thompson, E. A. [1952] (1981). "Revueltas campesinas en la Galia e Hispania tardorromanas”. En Finley, M. I. (ed.). Estudios sobre historia antigua. Akal, Madrid, 333-348.

Trément, F. (2001). "Habitat et peuplement en Provence à la fin de l'Antiquité". En Ouzoulias, P. y otros (dirs.). Op. cit., 275-302.

Van Dam, R. (1985). Leadership and Comunitiy in late antique Gaul. University of California Press, Berkeley y Los Ángeles.

Van Dam, R. (2005). "Merovingian Gaul and the Frankish conquest". En NCMH, vol. $1,193-231$.

Van Ossel, P. (2010). “De la «villa» au village: les premices d'une mutation”. En Yante, J.-M. y Bultot-Verleysen, A.-M. (eds.). Autour du «village». Etablissements humains, finages et communautés rurales entre Seine et Rhin (IVe-XIIIe siècles). Actes du colloque international de Louvain-la-Neuve, 16-17 mai 2003. Publications de l'Institut d'études médiévales, Louvain-la-Neuve, 219-236.

Verlinden, C. (1955). L'esclavage dns l'Europe médiévale, t. 1, Péninsule ibériqueFrance. "De Tempel”, Brujas.

Verlinden, C. (1977). L'esclavage dans l'Europe médiévale, t. 2, Italie, colonies italiennes du Levant, Levant latin, Empire byzantin. Rijksuniversiteit te Gent, Gante.

Vilar, P. (1980). “¿Economía campesina?”. En Vilar, P. Iniciación al vocabulario del análisis histórico. Crítica, Barcelona, 265-311. 
Walbank, F. W. [1969] (1996). La pavorosa revolución. La decandencia del Imperio romano en Occidente. Alianza, Madrid.

Ward-Perkins, B. (2000a). "Land, labour and settlement". En $C A H$, vol. 14, 315-345.

Ward-Perkins, B. (2000b). "Specialized production and exchange". En CAH, vol. 14, 346-391.

Ward-Perkins, B. (2005). The fall of Rome and the end of civilization. Oxford University Press, Oxford.

Werner, K. F. (1984). Les origines (avant l'an mil). Fayard, París.

Werner, K. F. (1998). Naissance de la noblesse. Fayard, París.

Whitby, M. (2000). “The Balkans and Greece, 420-602”. En CAH, vol. 14, 701-730.

Whittaker, C. R. [1976]. “Agri deserti”. Reimpreso en Whittaker, C. R. (1993a). Land, City and Trade in the Roman Empire. Variorum Reprints, Aldershot, 137-165 y 194-200.

Whittaker, C. R. [1980]. "Inflation and the economy in the fourth century A. D.". Reimpreso en Whittaker, C. R. (1993a), 1-22.

Whittaker, C. R. [1982]. "Labour Supply in the Later Roman Empire”. Reimpreso en Whittaker, C. R. (1993a), 171-179.

Whittaker, C. R. [1987]. "Circe's Pigs: From Slavery to Serfdom in the Later Roman World”. Reimpreso en Whittaker, C. R. (1993a), 88-120.

Whittaker, C. R. (1993b). "Landlords and warlords in the later Roman Empire". En Rich, J. y Shipley, G. (eds.). War and Society in the Roman World. Routledge, Londres y Nueva York, 277-302.

Whittaker, C. R. y Garnsey, P. (1998). "Rural life in the later Roman Empire". En CAH, vol. $13,277-311$.

Wickham, C. [1985] (2003). "La singularidad del Este”. Anales de Historia Antigua, Medieval y Moderna, 35-36, 185-218.

Wickham, C. (1989). "La otra transición: del mundo antiguo al feudalismo". Studia Historica. Historia Medieval, 7, 7-36.

Wickham, C. (1998). “Overview: production, distribution and demand”. En Hodges, R. y Bowden, W. (eds.). Op. cit., 279-292.

Wickham, C. (2003). "La caída de Roma no tendrá lugar". En Little, L. K. y Rosenwein, B. (eds.). La Edad Media a debate. Akal, Madrid, 80-101.

Wickham, C. (2005). Framing the Early Middle Ages. Oxford University Press, Oxford. 
Wickham, C. (2012). "Fuerzas productivas y lógica económica del modo de producción feudal”. Sociedades Precapitalistas. Revista de historia social, 1/2. Disponible en http://www.sociedadesprecapitalistas.fahce.unlp.edu.ar/.

Wightman, E. M. (1978). “The pattern of rural settlement in Roman Gaul”. Aufstieg und Niedergang der Römischen Welt, 2/4, 584-657.

Wightman, E. M. (1985). Gallia Belgica. B. T. Batsford Ltd., Londres.

Williams, S. y Friell, G. (1999). The Rome that did not fall: the survival of the East in the fifth century. Routledge, Londres y Nueva York.

Wolf, E. R. (1980). "Relaciones de parentesco, de amistad y de patronazgo en las sociedades complejas”. En AA. VV. Antropología social de las sociedades complejas. Alianza, Madrid, 19-52.

Wolfram, H. (1990). History of the Goths. University of California Press, Los Ángeles.

Wolfram, H. (1997). "Neglected evidence on the accomodation of barbarians in Gaul". En Pohl, W. (ed.). Op. cit., 181-183.

Wood, I. N. (1992). "Continuity or calamity?: the constraints of literary models". En Drinkwater, J. F. y Elton, H. (eds.). Op. cit., 9-18.

Wood, I. N. (1994). The Merovingian Kingdoms, 450-751. Longman, Londres y Nueva York.

Wood, I. N. (1998). "The barbarian invasions and the first settlements". En $C A H$, vol. $13,516-537$.

Wood, I. N. (2003). "Gentes, Kings and Kingdoms. The emergence of states: the Kingdom of the Gibichungs". En Goetz, H.-W., Jarnut, J. y Pohl, W. (eds.). Regna and Gentes. Brill, Leiden y Boston, 243-269.

Zadora-Rio, E. (2009). "Early medieval villages and estate centres in France (c. 3001100)". En Quirós Castillo, J. A. (dir.). The archaeology of early medieval villages in Europe. Universidad del País Vasco, Zarautz, 77-98. 